JOINT TRANSPORTATION RESEARCH PROGRAM

FHWA/IN/JTRP-2008/28

Final Report

UNDERSTANDING THE IMPACT OF INDOT

PROJECTS ON AUTOMOTIVE INDUSTRY

CLUSTER LOGISTICS COSTS: A CASE STUDY OF

THE HONDA PLANT

Ananth Iyer

Barry Partridge

Mary Pilotte

Pete Mast

Gerald Simms

February 2010 


\section{TECHNICAL Summary}

INDOT Research

Technology Transfer and Project Implementation Information

TRB Subject Code: 15-4 Economic Impact

Publication No. FHWA/IN/JTRP-2008/28, SPR-3216

February 2010

Final Report

\section{Understanding the Impact of INDOT Projects on Automotive Industry Cluster Logistics Costs: A Case Study of the Honda Plant \\ Introduction}

This study focuses on understanding the impact of INDOT projects on the Honda, Greensburg plant's supply chain. The goal of the study was the following:

(a) Identify approaches for INDOT to be an active partner in facilitating supply chain effectiveness.

(b) Maximize the economic impact of INDOT projects on the Honda affiliated automotive Cluster in South Central Indiana.

(c) Create a framework for INDOT to utilize in the future, when prospective economic partners are in discussions with the state.

This study was ongoing in 2007-2008, thus many of the decisions regarding Honda's supply chain required identification of possible future evolutions of the yet developed supply chain. As part of this study, we mapped out the existing supply chain to Honda's plants in Ohio and Toyota's plant in Indiana. Approximately 51 managers including Honda officials, competing OEM locations, academic publications, supply chain participants, economic development officials, INDOT personnel and consultants were interviewed to develop a fact base and for research input. We also obtained data regarding planned "Major Moves" projects already approved and in the region of interest. Finally, we developed strategic choices and grouped associated projects into strategic bundles that could be used by INDOT to better understand their link to Honda's supply chain competitiveness in Indiana.

\section{Findings}

A summary of the results of this study include possible strategic choices being grouped under three different categories that we termed "Shared Supply Focus", "Hoosier Automotive Focus" or "Reclamation Focus". A summary of the results of this analysis are as follows:

(a)Speed counts - Reprioritizing existing projects can provide the difference between being viewed as an economic development leader, or a support service follower.

(b) It's not too late -INDOT has 12-24 months yet to plan and execute improvements that would benefit economic development.

(c) Evaluating projects strategically can have a significant impact on economic development outcomes in the future.

We believe that the results of this focused study suggest that a strategic approach to projects can enable INDOT to enhance its role as a contributor to industrial supply chain competitiveness in Indiana. 


\section{Implementation}

The study suggests developing the following as part of the implementation plan:

Use known and approved project data to evaluate the cumulative project impact on flows, safety and other factors identified in this study throughout the identified focus areas/regions. This can be combined with estimated flows associated with the Honda
Greensburg operation and related supply chain and accomplished through the use of existing INDOT models/tools without further cost of development.

It is suggested that an INDOT official in the planning area volunteer to take this implementation recommendation forward.

\section{Contacts}

For more information:

\section{Prof. Ananth Iyer}

Principal Investigator

School of Civil Engineering

Purdue University

West Lafayette IN 47907

Phone: (765) 494-4514

Fax: (765) 497-2402

E-mail: aiyer@purdue.edu
Indiana Department of Transportation

Division of Research

1205 Montgomery Street

P.O. Box 2279

West Lafayette, IN 47906

Phone: (765) 463-1521

Fax: (765) 497-1665

\section{Purdue University}

Joint Transportation Research Program

School of Civil Engineering

West Lafayette, IN 47907-1284

Phone: (765) 494-9310

Fax: (765) 496-7996

E-mail: jtrp@ecn.purdue.edu

http://www.purdue.edu/jtrp 
Final Report

FHWA/IN/JTRP-2008/28

\title{
Understanding the Impact of INDOT Projects on Automotive Industry Cluster Logistics Costs: A Case Study of the Honda Plant
}

\author{
by \\ Ananth Iyer \\ Professor \& Principal Investigator \\ Barry Partridge \\ JTRP Project Administrator \\ Mary Pilotte \\ DCMME/GSCMI Project Mgr. \\ and \\ Pete Mast \\ Gerald Simms \\ Graduate Research Assistants \\ Krannert School of Management \\ Joint Transportation Research Program \\ Project No. C-36-67OOOO \\ File No. 9-10-92 \\ SPR-3216 \\ Prepared in Cooperation with the \\ Indiana Department of Transportation and the \\ U.S. Department of Transportation \\ Federal Highway Administration
}

The contents of this report reflect the views of the author who is responsible for the facts and the accuracy of the data presented herein. The contents do not necessarily reflect the official views or policies of the Indiana Department of Transportation or the Federal Highway Administration at the time of publication. This report does not constitute a standard, specification, or regulation.

Purdue University

West Lafayette, Indiana 47907

February 2010 
TECHNICAL REPORT STANDARD TITLE PAGE

\begin{tabular}{|c|c|c|}
\hline $\begin{array}{l}\text { 1. Report No. } \\
\text { FHWA/IN/JTRP-2008/28 }\end{array}$ & 2. Government Accession No. & 3. Recipient's Catalog No. \\
\hline \multirow{2}{*}{\multicolumn{2}{|c|}{$\begin{array}{l}\text { 4. Title and Subtitle } \\
\text { Understanding the Impact of INDOT Projects on Automotive Industry Cluster } \\
\text { Logistics Costs: A Case Study of the Honda Plant }\end{array}$}} & $\begin{array}{l}\text { 5. } \quad \text { Report Date } \\
\text { February } 2010\end{array}$ \\
\hline & & 6. Performing Organization Code \\
\hline \multicolumn{2}{|c|}{$\begin{array}{l}\text { 7. Author(s) } \\
\text { Ananth Iyer, Barry Partridge, Mary Pilotte, Pete Mast, Gerald Simms }\end{array}$} & $\begin{array}{l}\text { 8. Performing Organization Report No. } \\
\text { FHWA/IN/JTRP-2008/28 }\end{array}$ \\
\hline \multirow{2}{*}{\multicolumn{2}{|c|}{$\begin{array}{l}\text { 9. Performing Organization Name and Address } \\
\text { Joint Transportation Research Program } \\
550 \text { Stadium Mall Drive } \\
\text { Purdue University } \\
\text { West Lafayette, IN 47907-2051 }\end{array}$}} & 10. Work Unit No. \\
\hline & & $\begin{array}{c}\text { 11. Contract or Grant No. } \\
\text { SPR-3216 }\end{array}$ \\
\hline \multirow{2}{*}{\multicolumn{2}{|c|}{$\begin{array}{l}\text { 12. Sponsoring Agency Name and Address } \\
\text { Indiana Department of Transportation } \\
\text { State Office Building } \\
100 \text { North Senate Avenue } \\
\text { Indianapolis, IN } 46204\end{array}$}} & $\begin{array}{l}\text { 13. Type of Report and Period Covered } \\
\text { Final Report }\end{array}$ \\
\hline & & 14. Sponsoring Agency Code \\
\hline
\end{tabular}

15. Supplementary Notes

Prepared in cooperation with the Indiana Department of Transportation and Federal Highway Administration.

16. Abstract

This study focuses on understanding the impact of INDOT projects on the Honda, Greensburg plant's supply chain. The goal of the study was the following:

(a) Identify approaches for INDOT to be an active partner in facilitating supply chain effectiveness.

(b) Maximize the economic impact of INDOT projects on the Honda affiliated automotive Cluster in South Central Indiana.

(c) Create a framework for INDOT to utilize in the future, when prospective economic partners are in discussions with the state.

Detailed data analyses for many of the decisions regarding Honda's supply chain required identification of possible future evolutions of the supply chain. As part of this study the existing supply chain at Honda's plants in Ohio and Toyota's plant in Indiana were mapped out. Approximately 51 managers including Honda officials, competing OEM locations, academic publications, supply chain participants, economic development officials, INDOT personnel and consultants were interviewed to develop a fact base and for research input. We obtained data regarding planned "Major Moves" projects already approved and in the region of interest. Finally, we developed strategic choices and grouped associated projects into strategic bundles that could be used by INDOT to better understand their link to Honda's supply chain competitiveness in Indiana.

A summary of the results of this study includes possible strategic choices being grouped under three different categories we termed "Shared Supply Focus", "Hoosier Automotive Focus" and "Reclamation Focus". A summary of the results are as follows:

(a) Speed counts - Reprioritizing existing projects can provide the difference between being viewed as an economic development leader, or a support service follower.

(b) It's not too late -INDOT has 12-24 months yet to plan and execute improvements that would benefit economic development.

(c) Evaluating projects strategically can have a significant impact on economic development outcomes in the future.

We believe that the results of this focused study suggest that a strategic approach to projects can enable INDOT to enhance its role as a contributor to industrial supply chain competitiveness in Indiana.

\section{Key Words}

Automotive, supplier, OEM, Honda, Toyota, supply chain, economic development, Tier 1, Tier 2, Ohio, economic impact, distribution, manufacturing, production, JIT, Japanese, Greensburg, Indiana.

\begin{tabular}{|c|c|c|c|}
\hline $\begin{array}{c}\text { 19. Security Classif. (of this report) } \\
\text { Unclassified }\end{array}$ & $\begin{array}{c}\text { 20. Security Classif. (of this page) } \\
\text { Unclassified }\end{array}$ & 21. No. of Pages & 22. Price \\
\hline
\end{tabular}

\section{Distribution Statement}

No restrictions. This document is available to the public through the National Technical Information Service, Springfield, VA 22161 
A Case Study of the Honda Plant SPR-3216 


\section{Table of Contents}

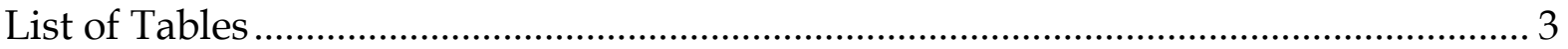

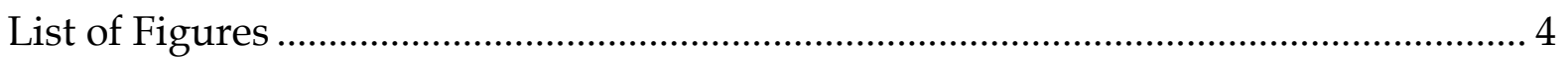

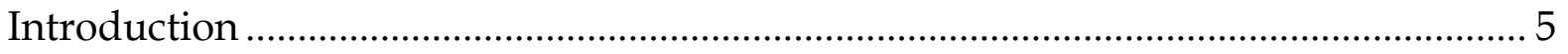

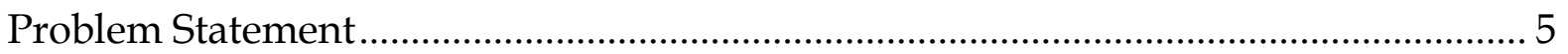

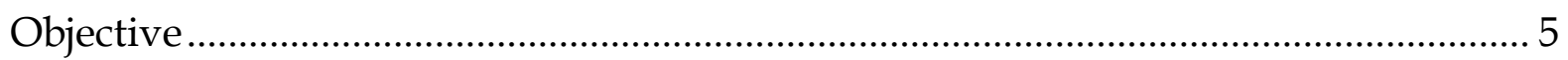

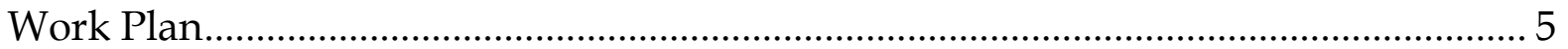

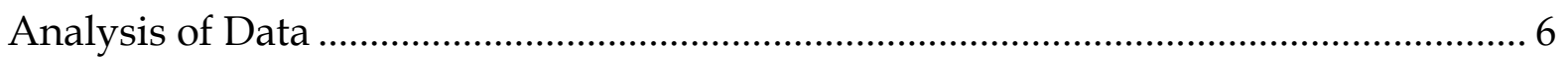

Phase 1: Completed August 2007 ............................................................................ 6

Economic Development Radius:............................................................................ 7

The Ohio Honda plant supply chain::...................................................................... 9

Phase 2: Report completed in November 2007 ............................................................ 13

Phase 3: Completed and presented in July 2008........................................................... 25

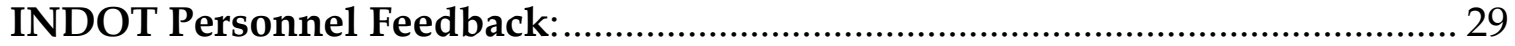

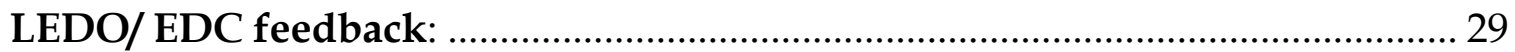

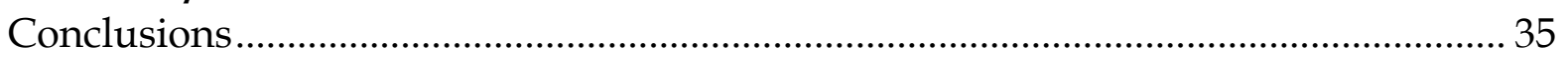

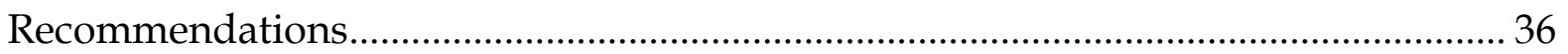

Expected Benefits/Deliverables/Implementation/Cost Savings.................................... 36 


\section{List of Tables}

Table 1: Cities within the 90 mile Economic Development Radius (EDR)................ 8

Table 2: Reclamation focus cities with distances to Greensburg, IN..................... 15

Table 3: New Cluster focus cities with distances to Greensburg, IN................... 17

Table 4: Automotive focus cities with distances to Greensburg, IN .................... 19

Table 5: Ohio focus cities with distances to Greensburg, IN ............................ 22

Table 6: Rail Access focus cities with distances to Greensburg, IN ....................... 24

Table 7: Honda Ohio facility details by location .................................... 27

Table 8: Interview Summary for Data Collection..................................... 28

Table 9: Closed Auto Suppliers with distances to Honda plants.......................... 34

Table 10: Closed Auto Suppliers - supplier tier viability ..............................34 


\section{List of Figures}

Figure 1: Map- 30, 60, \& 90 mile Greensburg, Indiana (EDR) state view............... 7

Figure 2: Map - 30, 60, \& 90 mile Greensburg, Indiana (EDR) regional view............. 8

Figure 3: Map - 30, 60, \& 90 mile Marysville, Ohio (EDR) state view .................. 9

Figure 4: Map - Honda Supplier locations - Ohio ................................ 9

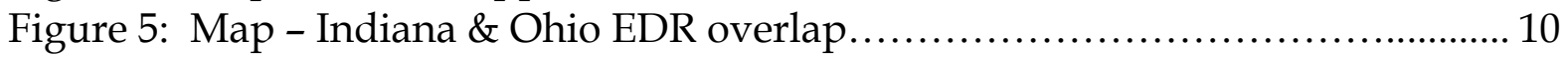

Figure 6: Map - Indiana \& Ohio EDR prospective employee shared zone.............. 10

Figure 7: Graph - Major Moves projects impacting Indiana EDR.................... 12

Figure 8: Graph - Contract letting d-base projects impacting Indiana EDR............. 12

Figure 9: Graph - Major Moves projects categorized by direction driver.............. 12

Figure 10: Graph - Contract letting database categorized by direction driver........ 12

Figure 11: Map - Candidate/target plants in Reclamation Focus zone.............. 14

Figure 12: Map - Routes of consideration in Reclamation Focus zone................ 15

Figure 13: List - Major Moves projects in Reclamation Focus ....................... 15

Figure 14: List - Contract letting d-base projects in Reclamation Focus ............... 16

Figure 15: Map - New Cluster Focus region.................................... 16

Figure 16: Map - Potential New Cluster regions by city ......................... 17

Figure 17: List - Major Moves projects in New Cluster Focus region.................. 18

Figure 18: List - Contract letting d-base projects in New Cluster Focus region....... 18

Figure 19: Map - Hoosier Automotive Focus region ................................................ 19

Figure 20: Map - Hoosier Automotive corridor, Princeton/Greensburg, IN.........20

Figure 21: List - Major Moves projects in Hoosier Auto Focus region................. 20

Figure 22: List - Contract letting d-base projects in Hoosier Auto Focus region.... 20

Figure 23: Map - Ohio Focus region....................................... 21

Figure 24: List - Major Moves projects in Ohio Focus region..................... 22

Figure 25: List - Contract letting d-base projects in Ohio Focus region............... 22

Figure 26: Map - Rail Access Focus........................................... 23

Figure 27: List - Major Moves \& CL D-base projects in Rail Access region...........24

Figure 28: Diagram - Honda production by location.......................... 25

Figure 29: Diagram - Greensburg, IN Honda Plant layout....................... 25

Figure 30: Diagram - Honda's tier supply model................................. 26

Figure 31: Map - North American Honda suppliers............................. 26

Figure 32: Map - Google Earth detail of IN/Oh suppliers........................ 28

Figure 33: Map - Feedback summary of suggested projects from interviews........ 30

Figure 34-39: List - Major Moves projects related to suggestions from intvw.....30-32

Figure 40: Map - Reclamation Focus routes of emphasis........................33 


\section{Introduction}

The Honda plant opening was scheduled to be in November 2008, with this study launched in June 2007 (see apndx. 1). The goal of the study was to understand how Indiana Department of Transportation's (INDOT) projects affected the competitiveness of Honda's supply chain in Indiana. Since many of the decisions by suppliers had not been announced while this study was in progress, data was collected through surveys, academic reports, interviews and analysis. The study was completed in phases. Note that preliminary results of one phase were modified as the project unfolded. Thus, it is essential to read this document as a series of cascading phases, with the final phase summarizing our study results.

\section{Problem Statement}

The goal of the study was the following:

(a) Identify approaches for INDOT to be an active partner in facilitating supply chain effectiveness.

(b) Maximize the economic impact of INDOT projects on the Honda affiliated automotive Cluster in South Central Indiana.

(c) Create a framework for INDOT to utilize in the future, when prospective economic partners are in discussions with the state.

\section{Objective}

This project proposes to develop primary data through interactions with area economic development personnel, Manufacturing Extension personnel, Honda sources, INDOT personnel and potential supplier executives to maximize INDOT facilitated economic impact maximization.

\section{Work Plan}

In order to understand the role and impact of INDOT projects on economic development in the region around the Honda plant, the research team aimed to work with county officials, address suppliers in locations around Shelbyville, Connersville, New Castle, etc., evaluate adjustments to the Central Indiana Railroad, and discuss the impact of INDOT interchanges in Greensburg and in surrounding regions. The purposeful focus was to target all potential towns and associated counties within a reasonable distance from Greensburg as potential data sources. In addition, all published sources of data and potential data from other OEM plants in Indiana were to be collected and analyzed.

This study was ongoing in 2007-2008, thus many of the decisions regarding Honda's supply chain required identification of possible future evolutions of the supply chain. As part of this study we mapped out the existing supply chain to Honda's plants in Ohio and Toyota's plant in Indiana. Approximately 51 managers including Honda officials, competing OEM locations, academic publications, supply chain participants, economic development officials, INDOT personnel and consultants were interviewed to develop a fact base and for research input. We obtained data regarding planned "Major Moves" projects already approved and in the region of 
interest. Finally, we developed strategic choices and grouped associated projects into bundles that can be used by INDOT to better understand their link to Honda's supply chain competitiveness in Indiana.

The list of study advisory committee members, project administrator and principal investigator biography are provided at the end of the report. (See apndx. $2 \& 3$ )

\section{Analysis of Data}

Phase 1: Completed August 2007

First, some background information on Honda. Honda manufactures less than 15-20 percent of the value added in an automobile. The company relies on lean manufacturing and low on site inventories. Thus, exact sequencing of supplier deliveries to match the production sequence is crucial. In addition, components will be both imported and made locally, emphasizing the need to consider inter-modal linkages as well as flows from outside the state. These more complex material flows across various transportation options will require coordination of projects across entities including INDOT. Honda is known to focus on balancing its materials flows to stabilize transportation systems feeding its production. Outbound shipments of finished cars will use a combination of rail and truck. The first phase of the project, completed in August 2007, accomplished the following:

- Complete scrape of publicly available data related to Honda America (see apndx. 5)

- Creation of Honda relocation fact/data repository (see apndx. 6 for this and next three bullets below)

- Collection of transportation data \& rail line availability

- Summary of known Honda Indiana/Honda Ohio suppliers

- Mapping of known Honda Indiana/Ohio suppliers

- Synthesis of assertions from data collected to date

- Development of 4 possible "direction drivers"

In order to complete these steps, we made two assumptions:

1. Based on the reliability of executing structured "greenfield" best practices, Honda will essentially replicate the Marysville, Ohio operational expansion in Indiana.

2. Based on the inflexibility/immobility of certain supplier \& in house assets, we anticipate execution of a two pronged supply strategy based on the following expansion phases.

(Note that " $\mathrm{T}$ " refers to the time of launch date - November 2008) 


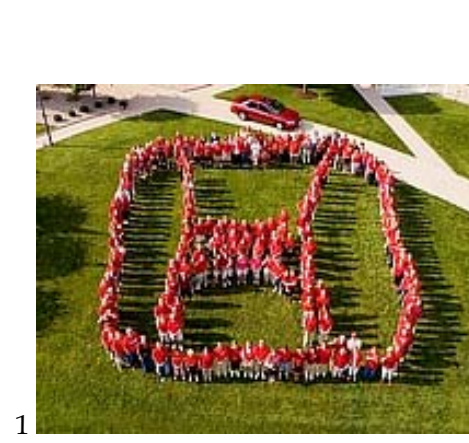

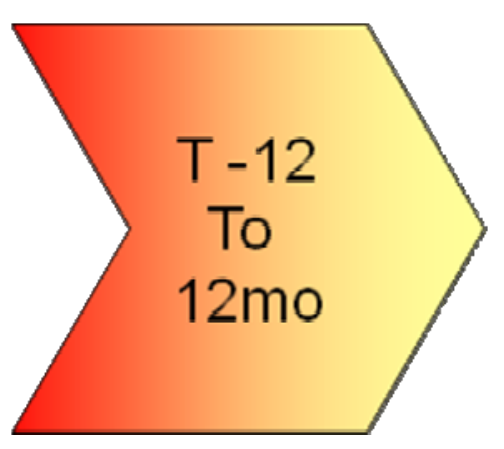

Low Volume ( 75-150 cars/day)

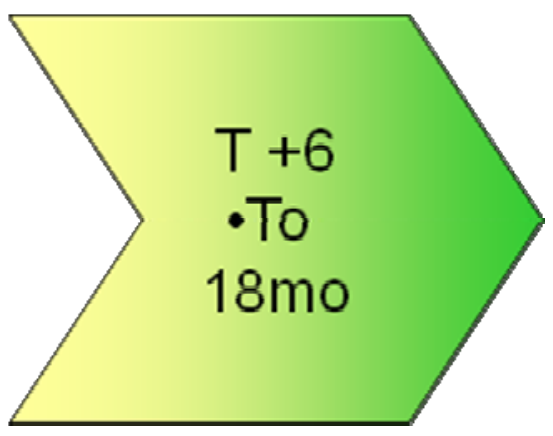

TARGET VOLUME ( $\sim 575$ cars/day)

\section{Economic Development Radius:}

Based on academic studies ${ }^{2}$ (see apndx. 4), we identified the following useful related concepts. The first is that Japanese firms create regional spaces of production. The second is that production is spatially focused around assembly, with $1^{\text {st }}$ tier usually physically closest, $2^{\text {nd }}$ tier further away, etc. The third is that geographic proximity is highly prized... because it is one means to ensure proximity of time. The first step was to develop such economic development radius circles around Greensburg, Indiana. The figure below shows the results (figure 1: Bands represent minutes; 15, $30,60 \& 90$ respectively).

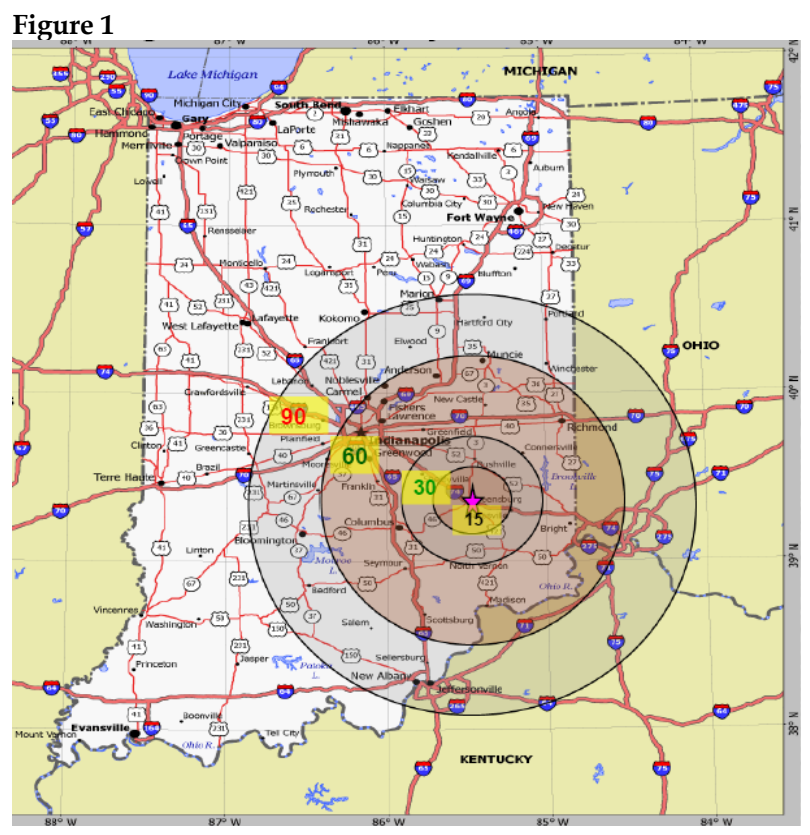

If we zoom in closer to the regions that are 45 minutes of travel time from Greensburg, we see the figure below (figure 2: Bands represent travel time; 15, 30, and 45 minutes respectively). 
Figure 2

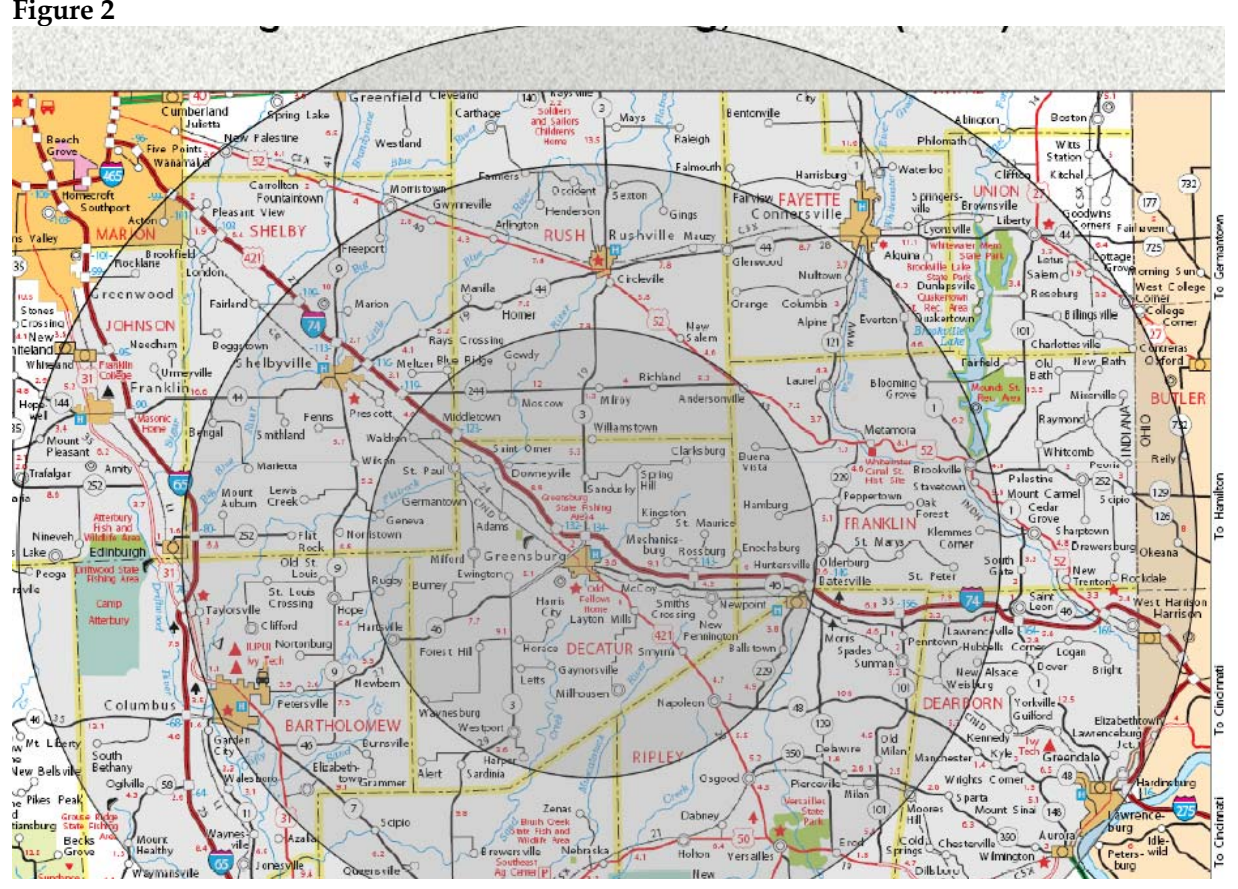

If we next consider Indiana cities that are within a 90 minute EDR of Greensburg, and collect the associated travel distance and commute time, we produce the following data (table 1):

Table 1

\section{Select Indiana Municipalities w/in $90 \mathrm{mi}$. EDR of Greensburg, IN}

\begin{tabular}{lcccccc} 
City & $\begin{array}{c}\text { Miles from } \\
\text { Greensburg }\end{array}$ & $\begin{array}{c}\text { Commute time } \\
\text { from Greensburg }\end{array}$ & City & $\begin{array}{c}\text { Miles from } \\
\text { Greensburg }\end{array}$ & $\begin{array}{c}\text { Commute time from } \\
\text { Greensburg }\end{array}$ \\
\hline Batesville & 17 & 20 minutes & Muncie & 63 & 1 hour, 37 minutes \\
Rushville & 19 & 31 minutes & Mooresville & 64 & 1 hour, 10 minutes \\
Shelbyville & 22 & 27 minutes & Noblesville & 65 & 1 hour, 10 minutes \\
Columbus & 28 & 47 minutes & Plainfield & 66 & 1 hour, 12 minutes \\
North & & Brownsburg & 71 & 1 hour, 15 minutes \\
Vernon & 30 & 46 minutes & Bloomington & 73 & 1 hour, 37 minutes \\
Connersville & 36 & 55 minutes & Richmond & 74 & 1 hour, 30 minutes \\
Franklin & 38 & 48 minutes & Martinsville & 75 & 1 hour, 20 minutes \\
Greenfield & 39 & 47 minutes & Lebanon & 80 & 1 hour, 22 minutes \\
New Castle & 44 & 1 hour, 9 minutes & Anderson & 81 & 1 hour, 26 minutes \\
Lawrence & 49 & 51 minutes & Winchester & 83 & 1 hour, 48 minutes \\
Indianapolis & 52 & 56 minutes & Elwood & 84 & 1 hour, 38 minutes \\
Carmel & 61 & 1 hour, 4 minutes & & &
\end{tabular}

This table allows us to focus our attention to these specific cities when we look more closely at the supply chain evolution.

\section{The Ohio Honda plant supply chain:}

If we now consider the Honda plant in Marysville, Ohio and examine its EDR we see the following picture emerge (figure 3: bands represent miles; 15, 30, 60 \& 90 respectively): 


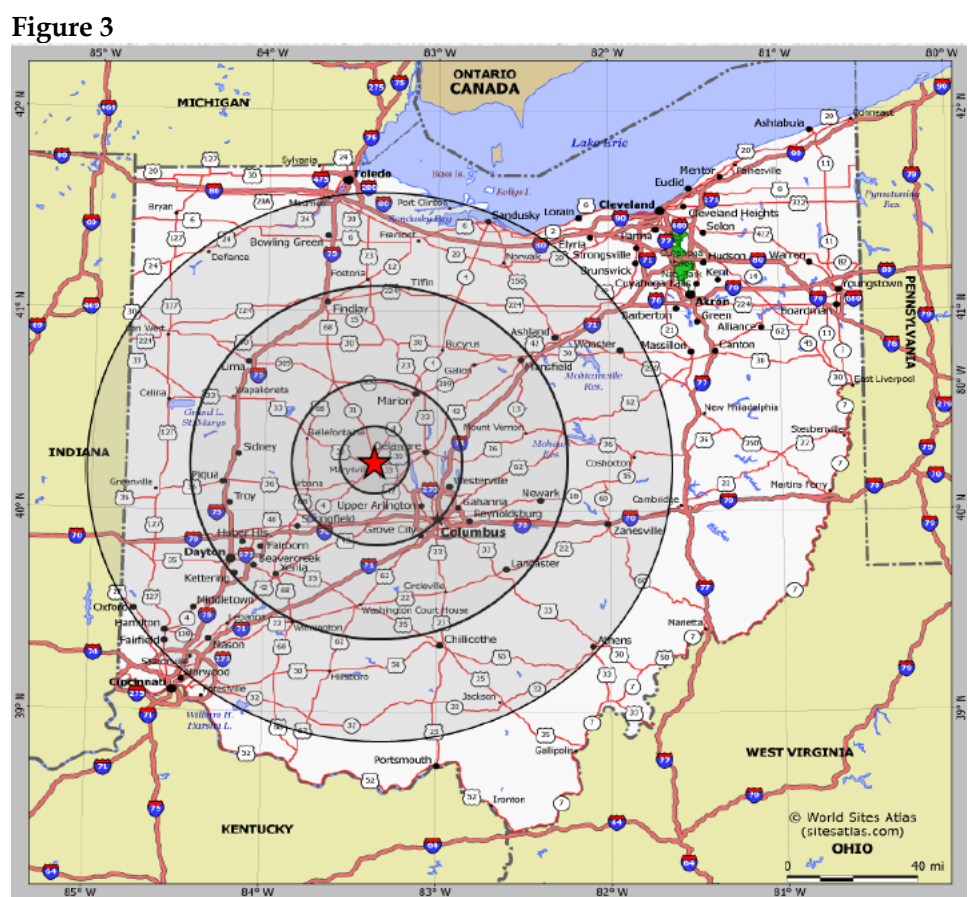

Tracking the suppliers that are located within the 90 mile EDR around the Marysville plant generates the following (figure 4):

The data collected shows that for the Marysville plant, of the 130 known Honda suppliers, 96 suppliers $(74 \%)$ are inside 90 mile EDR while 34 suppliers (26\%) are outside EDR. The location of these suppliers also shows a skewed distribution of suppliers primarily clustered in the southwest region. It thus appears that the Northeast region is left with an available employment pool for Honda plants.

Turning our attention to the Greensburg plant, the figure below (figure 5) shows the locations of all known Honda suppliers in both Indiana and Figure 4

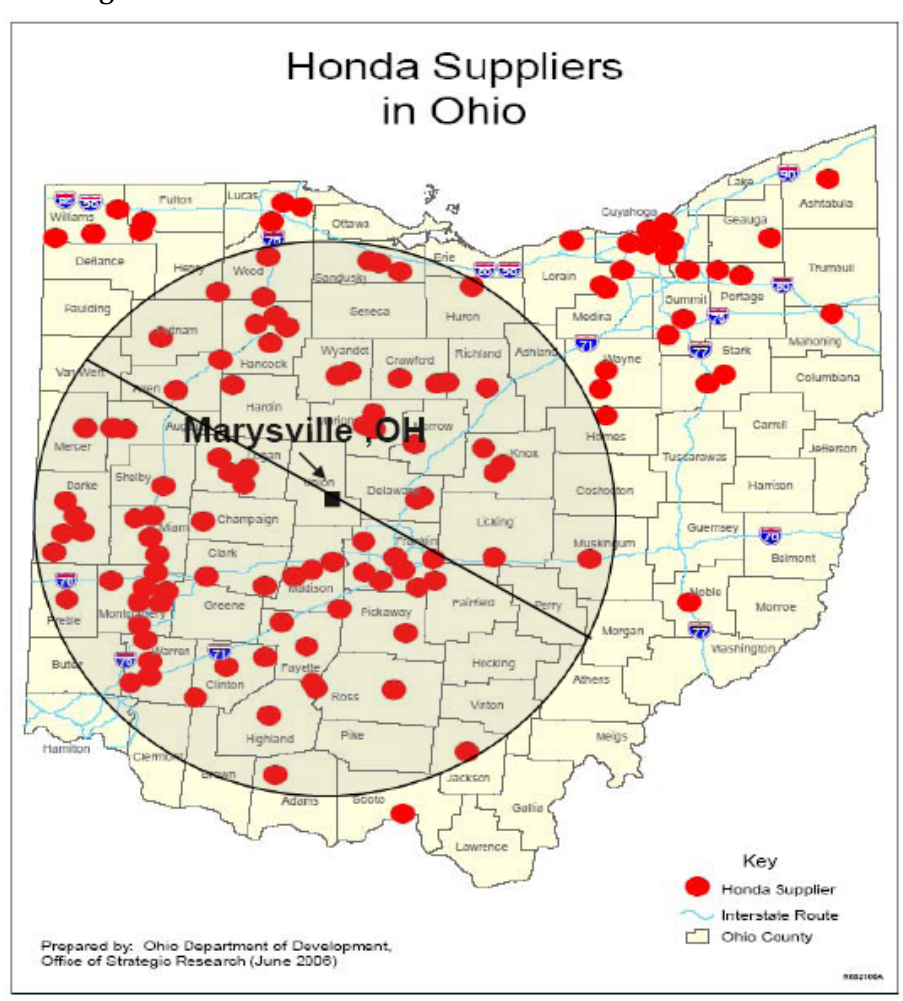

Ohio within the 90 mile EDR around the plants. 


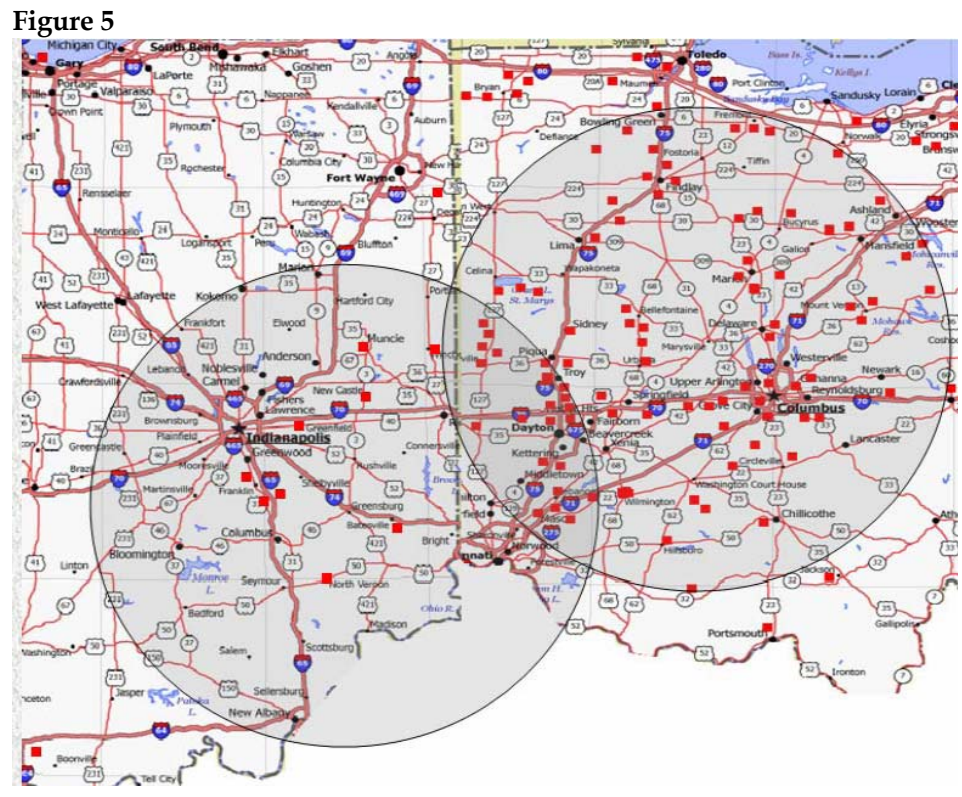

Notice that there is an overlap region of suppliers who remain within the EDR of 90 miles from both plants. This data suggests that the new Honda plant may well rely on a mix of suppliers from both Indiana and Ohio as the plant ramps up production. The possible shared zone from which employees may be used by Honda suppliers is shown below (figure 6).

The initial data analysis thus suggests that supplier locations will be closely tied to available employee pools that avoid conflicts with the employee base used in Honda's plants. It also suggests the need to think about the use of these employees at plants that use a multiplant perspective i.e., delivery to the Ohio and Indiana assembly plants.

Figure 6

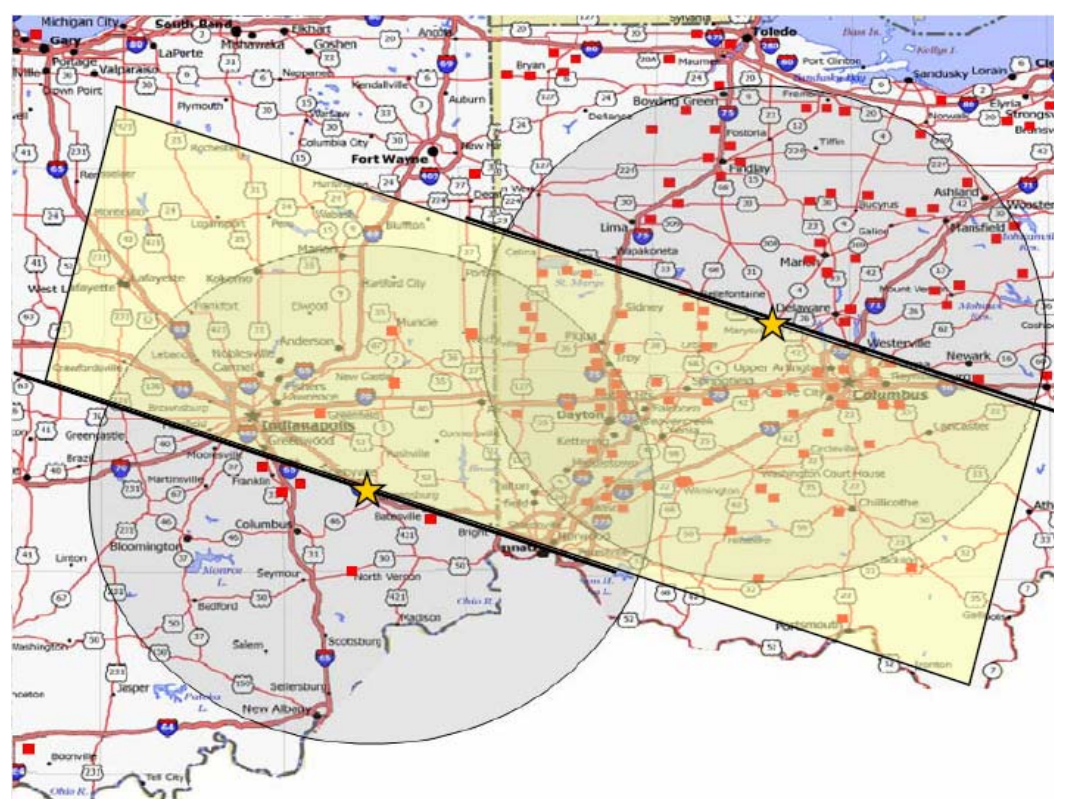

Based on this initial data analysis, we explored the following four specific direction drivers and their corresponding implications for INDOT and associated risks:

1. Key improvements to CIND lines ${ }^{3}$ will rally greater than expected supply exchange by rail.

Implication to INDOT

INDOT can choose to support smaller local projects along the improved rail line in support of CIND. 
$\underline{\text { Risks }}$

-Transportation issues related to rail ownership \& access to CIND. Rail not most cost effective for low cost/light weight components. -Component deliveries tied to rail shipping performance, which lacks historic reliability.

If this is the only strategy, there is no effective supply line competition (monopoly) which is not an effective choice for Indiana.

2. Honda supplies Greensburg operation with a few existing/newly established Indiana suppliers (20\%), with the balance supplied from existing Ohio partners $(80 \%)$

Implication to INDOT

Little local disruption beyond that already publicly discussed or underway with state and local INDOT projects.

$\underline{\text { Risks }}$

-Ohio aggressively competes with Indiana for business development and pre-empts Indiana economic development through incentives and better transportation alternatives.

3. Key suppliers are attracted into specific EDR clusters through active / reactive LEDO marketing, mimic the Ohio development patterns.

Implication to INDOT

INDOT can choose to reasonably anticipate cluster zones and emphasize project activity in these areas. (I.e. Indy, Rushville, Connersville)

Risks

-Choosing the "wrong" location for key improvements/investment and could face white elephant allegations.

4. Key suppliers not already within the EDR, opportunistically backfill the US automotive void (physical and human capital) created by the recent demise of auto/related suppliers.

\section{Implication to INDOT}

INDOT may choose to refocus project priority in these "reclaimed communities" in support of economic renovation, and the needs of new supplier transport lanes to Greensburg. 


\section{Risks}

-Honda profile suppliers may prefer greenfield opportunities over brownfield.

-Some suppliers may perceive worker/associate cultures and morale issues too much to overcome verses financial benefits/incentives.

The next question was the current mix of INDOT projects that may have some impact on the Greensburg EDR. We identified 175 projects under "Major Moves" and 301 projects from the contract letting database. Of these projects, the pie charts below (figure $7 \& 8$ ) show the number of projects that will impact the regions within the Greensburg EDR.

Figure $7 \& 8$

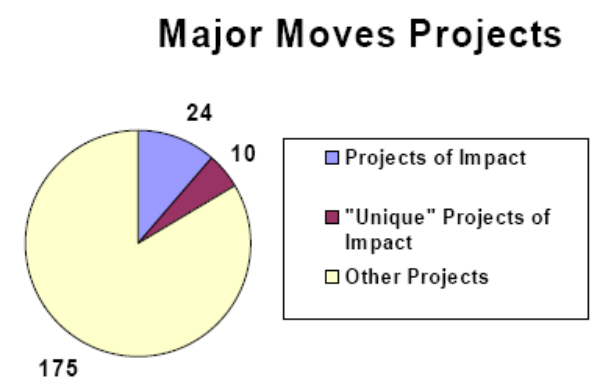

\section{Contract Letting Projects}
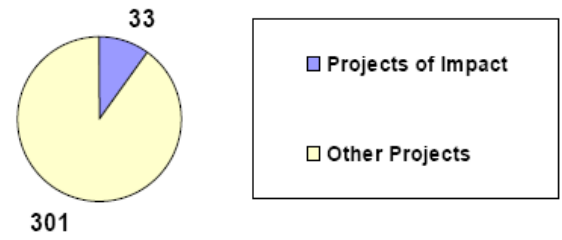

301

We then considered which projects aligned with the direction drivers that were identified earlier. The fractions of projects aligning with each direction driver are listed in the bar graphs below (figure $9 \& 10$ ).

Figure 9

\section{Major Moves Projects by Direction Driver}

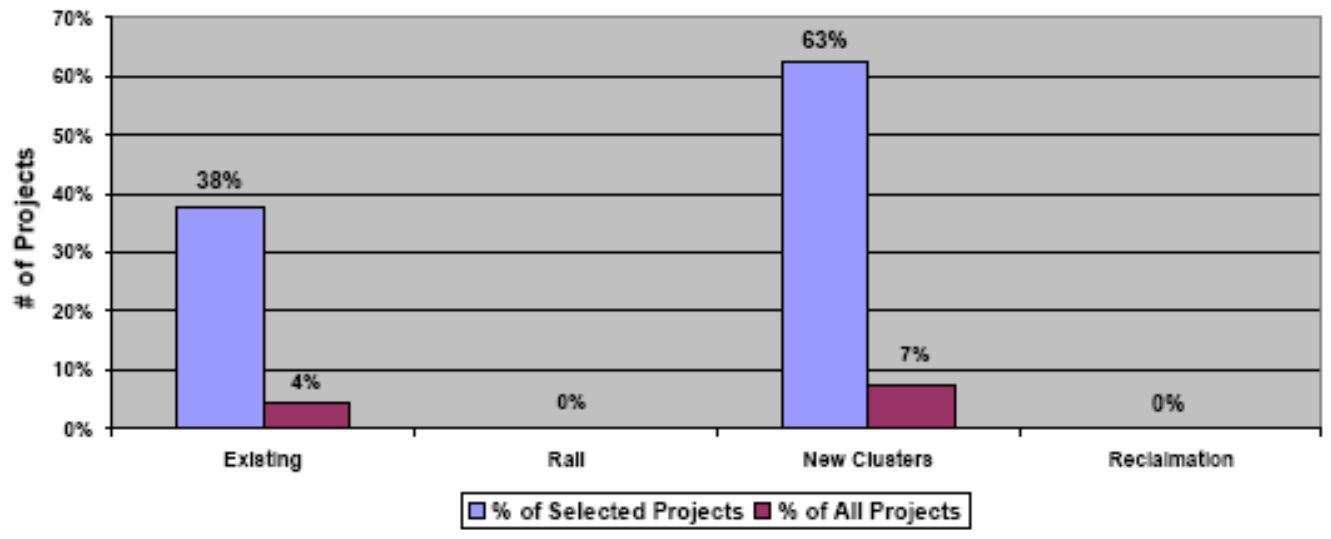




\section{Contracting Letting Projects \\ by Direction Driver}

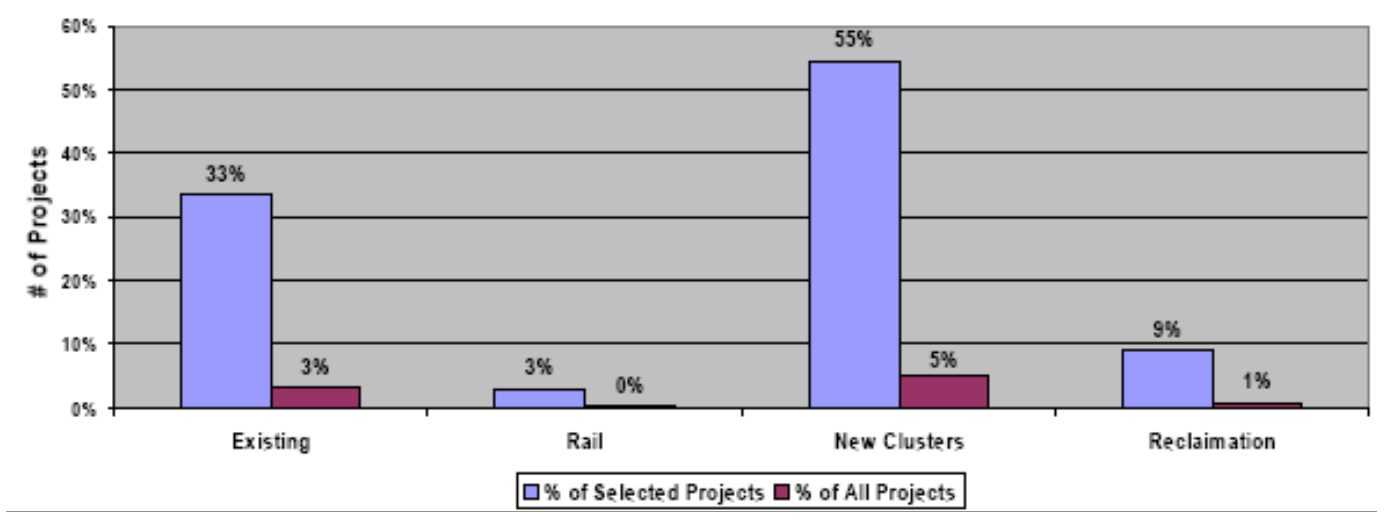

Given the data collected during this phase, the meeting discussions focused on whether the strategic groupings of projects were reasonable and if the projects that we identified and their timing would have an impact on the supply chain. There was also a need to collect direct information from supply chain participants to reinforce these possible direction drivers and their preference for each as part of a strategy.

\section{Phase 2: Report completed in November 2007}

This second phase of the analysis builds on the initial four strategies identified in the first phase by examining specific company locations and planning rules that were obtained from interviews of participants. During this phase we did not manage to get access to managers at Honda plants. Thus, based on discussions with senior managers at the Toyota plant in Princeton, Indiana, we learned that Toyota develops routes based on "industry average speeds" of $50 \mathrm{mph}$. We will use this planning rule to examine the competitiveness of Indiana suppliers. The perspective we use is the following:

\section{Any event, road condition or infrastructure limitation that prevents meeting this target of 50MPH average road speed, costs suppliers money and limits their competitiveness.}

This includes but is not limited to items such as:

- small towns/school zones with reduced speed limits,

- rail crossings \& bridges with weight restrictions,

- Bridges/roadways with insufficient consideration/treatment for weather conditions and,

- narrow roadways or roads without sufficient passing lanes 
Thus, the question for our team to focus on was, "how can INDOT project choices and priorities support this competitiveness objective?"

Due to the two phased expansion plan for production at the Greensburg plant, the project team felt is was not too late for INDOT to adjust planning related to project choices to improve the competitiveness objective for Honda Greensburg. In fact, it was estimated that INDOT had 12-24 months yet to plan and execute. Thus, evaluating projects strategically can have a significant impact on economic development outcomes in the future. As an example, reprioritizing existing projects can provide the difference between being viewed as an economic development leader, or a support service follower. The question then is how can INDOT project choices be reviewed and reprioritized to maximize their impact?

Each of the original evaluation themes below will be examined with this in mind.

a. Reclamation Focus: For key suppliers not already within the EDR, opportunistically backfill the US automotive void (physical and human capital) created by the recent demise of auto/related suppliers.

\section{Implications for INDOT}

-INDOT may choose to refocus project priority in these "reclaimed communities" in support of economic renovation, and the needs of new supplier transport lanes to Greensburg.

\section{$\underline{\text { Risks }}$}

-Honda profile suppliers may prefer greenfield opportunities over brownfield.

-Some suppliers may perceive worker/associate cultures and morale issues too much to overcome verses financial benefits/incentives.

Analysis:

The figure below (figure 11) shows candidate plants for the Reclamation focus and provides their average speed to get to Greensburg.

Figure 11

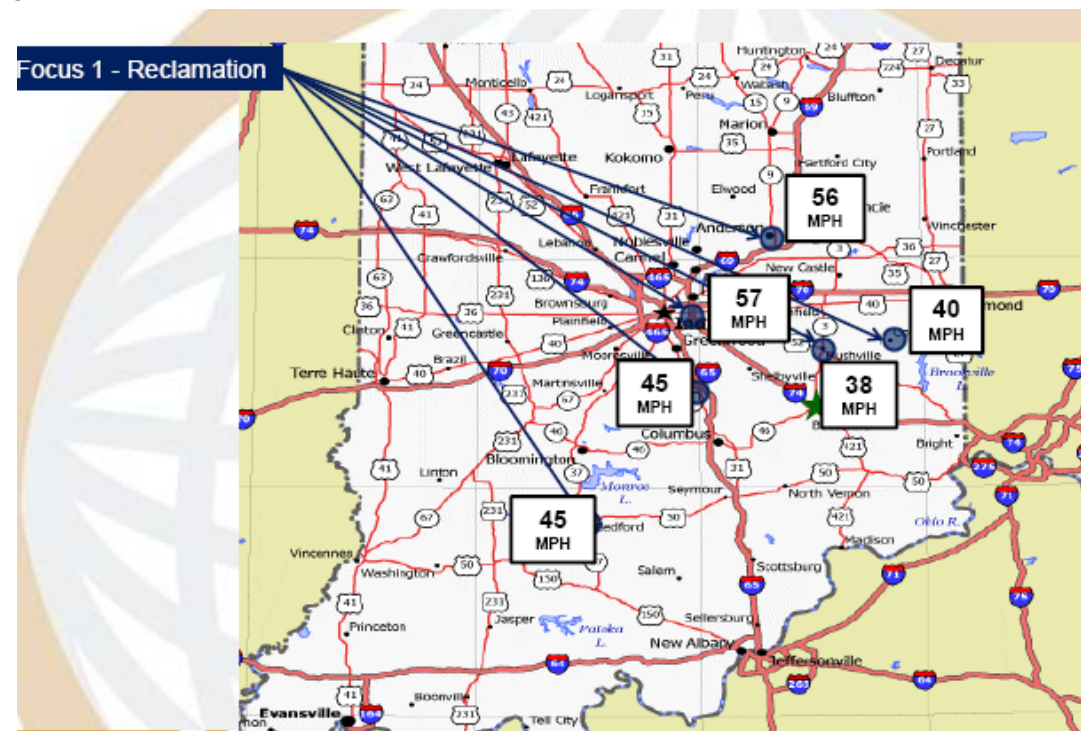


The associated cities where these plants are located are as follows (table 2):

Table 2

\begin{tabular}{|l|l|l|l|}
\hline City & $\begin{array}{l}\text { Time } \\
\text { (Mins) }\end{array}$ & Distance (MI) & $\begin{array}{l}\text { Average } \\
\text { Speed (MPH) }\end{array}$ \\
\hline Anderson & 88 & 81.9 & 55.84 \\
\hline Bedford & 105 & 78.68 & 44.96 \\
\hline Connersville & 55 & 35.97 & 39.24 \\
\hline Edinburgh & 37 & 27.97 & 45.36 \\
\hline Indianapolis & 55 & 51.98 & 56.71 \\
\hline Rushville & 31 & 19.72 & 38.17 \\
\hline
\end{tabular}

For each of these routes, the major INDOT projects that can affect the travel time are shown in the map below (figure 12):

Figure 12

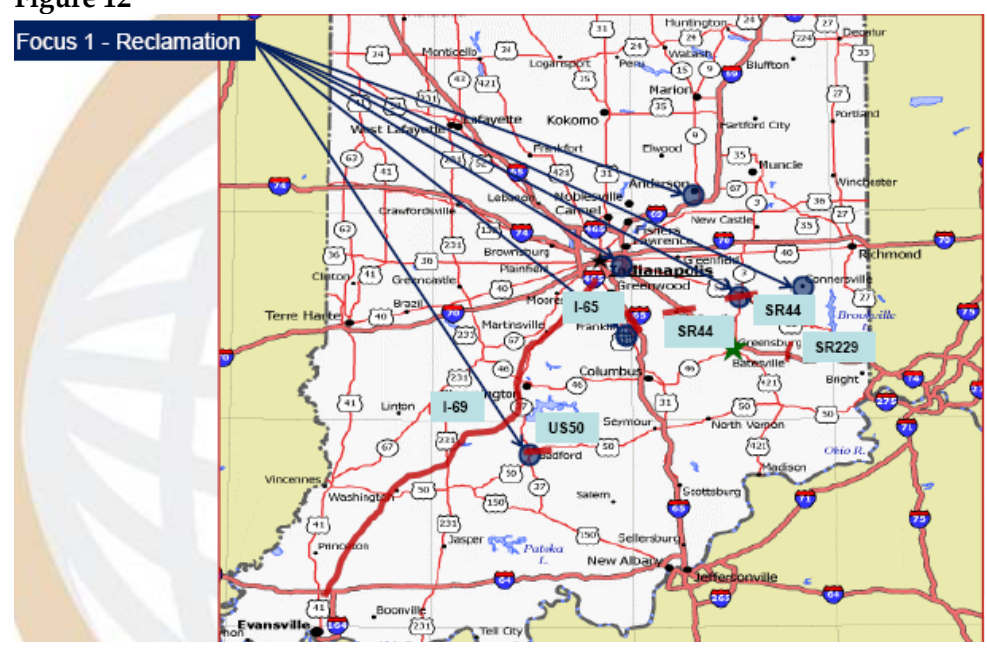

The associated specific projects from the "Major Moves" 7 list and the letting database $^{7}$ are as follows (figure $13 \& 14$ ):

Figure 13

\begin{tabular}{|c|c|c|c|c|c|c|c|}
\hline & & & Major Moves New Construction Projects (ou & f 209 listed proj & jects) & & \\
\hline Year & County & Route & Project Location & Note on Location & District & Project ID & cost \\
\hline 2007 & Hamilton & 169 & At $1-69$ and SR 238 (Phase I) & Southwest side of Indy & Greenfield & 4 & $\$ 7,768,254$ \\
\hline 2010 & Marion & 1465 & At SR 37 (S jct) & Southwest side of Indy & Greenfield & 4 & $\$ 7,768,254$ \\
\hline & & & From $0.5 \mathrm{mi} \mathrm{S}$ of $1-465$ interchange (75th St) to $0.5 \mathrm{mi} \mathrm{S}$ of 96 th St & & & & \\
\hline 2014 & Marion & 169 & Interchange & Southwest side of Indy & Greenfield & 4 & $\$ 7,768,254$ \\
\hline & & & From 0.5 mi s of $1-4$ & & & & \\
\hline 2015 & Marion & 169 & Interchange & Southwest side of Indy & Greenfield & 4 & $\$ 7,768,254$ \\
\hline 2009 & Various & 169 & New 169 Evansville to Indianapolis & Southwest side of Indy & Greenfield & 4 & $\$ 7,768,254$ \\
\hline 2010 & Various & 169 & New 169 Evansville to Indianapolis & Southwest side of Indy & Greenfield & 4 & $\$ 7,768,254$ \\
\hline 2011 & Various & 169 & New I 69 Evansville to Indianapolis & Southwest side of Indy & Greenfield & 4 & $\$ 7,768,254$ \\
\hline 2012 & various & 169 & New I 69 Evansville to Indianapolis & Southwest side of Indy & Greenfield & 4 & $\$ 7,768,254$ \\
\hline 2013 & various & 169 & New I 69 Evansville to Indianapolis & Southwest side of Indy & Greenfield & 4 & $\$ 7,768,254$ \\
\hline 2014 & Various & 169 & New I 69 Evansville to Indianapolis & Southwest side of Indy & Greenfield & 4 & $\$ 7,768,254$ \\
\hline 2015 & various & 169 & New I 69 Evansville to Indianapolis & Southwest side of Indy & Greenfield & 4 & $\$ 7,768,254$ \\
\hline 2007 & Franklin & SR 229 & From 1-74 to Six Pine Rd (CR 1000W) & Batesville & Seymour & 89 & $\$ 3,372,180$ \\
\hline
\end{tabular}


Figure 14

\begin{tabular}{|c|c|c|c|c|c|c|}
\hline Letting Date & County & Road & Location & Note on Location & District & Type of Work \\
\hline $12 / 12 / 2007$ & Rush & SR 44 & $\begin{array}{l}\text { From } 0.68 \text { mile } W \text { of } S R 3 \text { to } 0.18 \text { mile } E \text { of } \\
\text { SR } 3\end{array}$ & $f_{\text {Rushville }}$ & Greenfield & $\begin{array}{l}\text { Road Rehabilitation (3R/4R } \\
\text { Standards) }\end{array}$ \\
\hline $2 / 20 / 2008$ & Shelby & SR 244 & From $1-74$ to SR 3 & $\begin{array}{l}\text { East off of } 1-74 \text {, just } S \text { of } \\
\text { Shelbyville }\end{array}$ & Greenfield & Partial 3-R \\
\hline $11 / 14 / 2007$ & Shelby & SR 44 & From 1.7 miles W of SR 9 to SR 9 & In Shelbyville & Greenfield & $\begin{array}{l}\text { Road Rehabilitation (3R/4R } \\
\text { Standards) }\end{array}$ \\
\hline $12 / 12 / 2007$ & Shelby & SR 44 & $\begin{array}{l}\text { From } 1.95 \text { miles } W \text { of } 1-74 \text { to } 1.1 \text { miles } E \\
\text { of } 1-74\end{array}$ & In shelbyville & Greenfield & $\begin{array}{l}\text { Road Reconstruction (3R/4R } \\
\text { Standards) }\end{array}$ \\
\hline $8 / 22 / 2007$ & Johnson & 165 & $\begin{array}{l}\text { SR-252 Interchange to Whiteland Road } \\
\text { US } 50 \text { from SR } 37 \mathrm{~N} \mathrm{jct} \mathrm{to} \mathrm{"E"} \mathrm{St} \mathrm{in}\end{array}$ & $\mathrm{N}$ and $\mathrm{S}$ of Franklin & Seymour & $\begin{array}{l}\text { HMA Overlay, Preventive } \\
\text { Maintenance } \\
\text { HMA Overlay, Preventive }\end{array}$ \\
\hline $10 / 16 / 2008$ & Lawrence & US 50 & Bedford & Bedford & Vincennes & Daintenapce \\
\hline
\end{tabular}

Given these projects related to the reclamation focus, the corresponding questions that are relevant for INDOT are as follows:

- How will the planned projects affect average speeds to Greensburg?

- What projects will be necessary to get the speed limits to $50 \mathrm{mph}$ ?

- What will be the associated cost and completion time frame?

In order to answer these questions, we need data regarding the impact of projects from INDOT. This data has not been made available to the study team; hence these specific questions remain unanswered.

\section{b. New Cluster Focus: Key suppliers are attracted into specific EDR clusters} through active / reactive LEDO marketing and mimic the Ohio development patterns. (Figure 15)

\section{Implication for INDOT}

-INDOT can choose to reasonably anticipate cluster zones and emphasize project activity in these areas. (I. e. Indy, Rushville,

$\underline{\text { Risks }}$

Connersville)

Choice of "wrong" location for key improvements/investment and could face white elephant allegations.

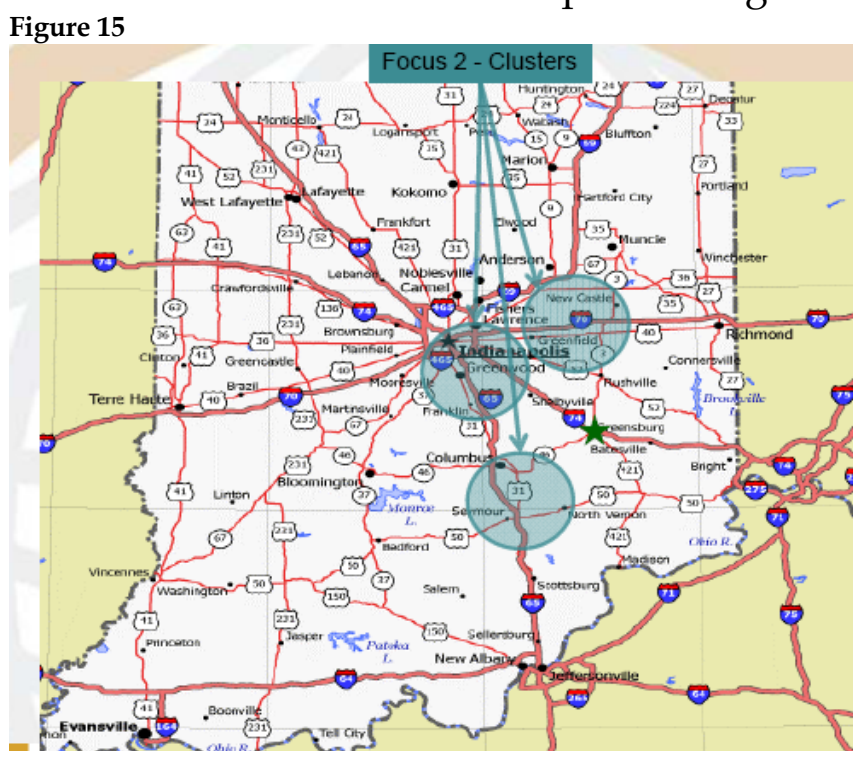


The associated towns and their distance and speed limit to Greensburg are shown below (table 3).

Table 3

\begin{tabular}{|l|l|l|l|}
\hline City & Time (Mins) & Distance (MI) & $\begin{array}{l}\text { Average Speed } \\
\text { (MPH) }\end{array}$ \\
\hline Batesville & 20 & 15.99 & 47.97 \\
\hline Columbus & 47 & 28.12 & 35.90 \\
\hline Edinburgh & 37 & 27.97 & 45.36 \\
\hline Franklin & 48 & 38.2 & 47.75 \\
\hline Greenfield & 48 & 38.52 & 48.15 \\
\hline Indianapolis & 55 & 51.98 & 56.71 \\
\hline New Castle & 69 & 44.03 & 38.29 \\
\hline North Vernon & 48 & 29.46 & 36.83 \\
\hline Seymour & 64 & 43.42 & 40.71 \\
\hline Whiteland & 51 & 42.9 & 50.47 \\
\hline
\end{tabular}

In order to identify these clusters, we first identified EDRs based on distance and travel time. We then found planned and existing supplier locations and expansions within these EDRs. Finally, we used Honda's supplier location policy (from Ohio and industry source data) to identify feasible clusters. As an example of three possible clusters, see the map below (figure 16)

Figure 16

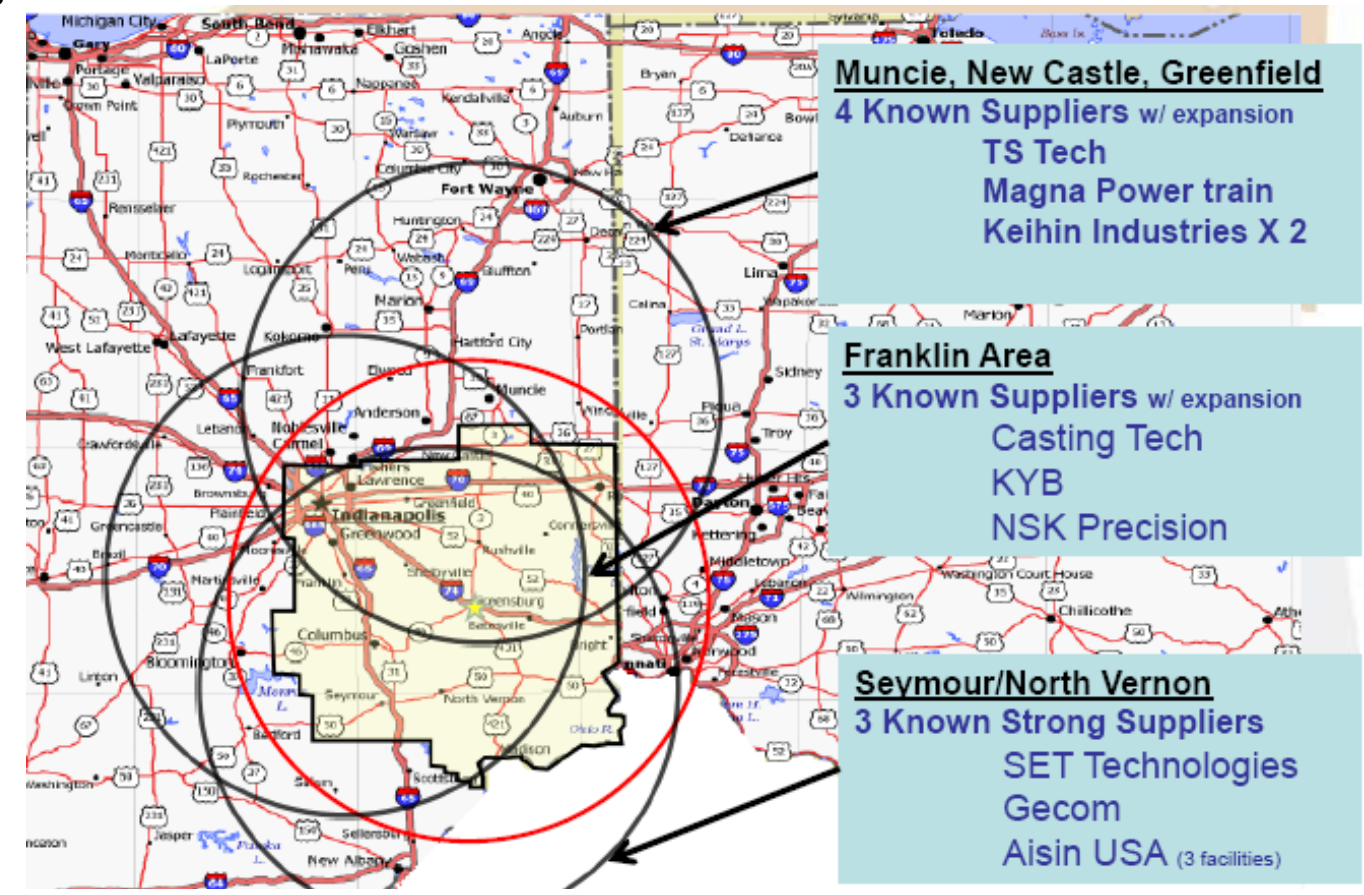

The "Major Moves" and letting database related projects in this region are then obtained as follows (figure $17 \& 18$ ): 
Figure 17

\begin{tabular}{|c|c|c|c|c|c|c|c|}
\hline \multirow[b]{2}{*}{ Year } & \multirow[b]{2}{*}{ county } & \multicolumn{5}{|c|}{ Major Moves New Construction Projects (out of 209 listed projects) } & \multirow[b]{2}{*}{ cost } \\
\hline & & Route & Project Location & Note on Location & District & Project ID & \\
\hline 2009 & Hancock & 170 & At Mt comfort Rd, 7.7 miles $W$ of SR 9 (phase II) & Close eastern suburbs of Indy & Greenfield & 25 & $\$ 25,636,128$ \\
\hline 2010 & Marion & 1465 & 1-70 interchange \& 1-465 mainline & East side of Indy & Greenfield & 1 & $\$ 72,363,798$ \\
\hline 2011 & Marion & 1465 & I-74 / US 136 Intrchge \& mainline (encumbr. 1) & Southeast side of Indy & Greenfield & 1 & $\$ 34,951,715$ \\
\hline 2012 & Marion & 1465 & 1-74 / US 136 Intrchge \& mainline (enc) & Southeast side of Indy & Greenfield & 1 & $\$ 34,951,715$ \\
\hline 2013 & Marion & 1465 & 1-74 / US 136 Intrchge \& mainline (encumbr. 3) & Southeast side of Indy & Greenfield & 1 & $\$ 34,951,715$ \\
\hline 2013 & Marion & 170 & st Road to $0.5 \mathrm{mi} \mathrm{E}$ & Close & Greenfield & 292 & $\$ 62,339,515$ \\
\hline 2014 & Jackson & us 50 & From US 3 & & Seymour & 259 & $\$ 20,759,781$ \\
\hline 2014 & Hancock & 170 & From 0.5 miles E of Mt Comfort Rd to 0.8 & Close e: & Greenfield & 292 & $\$ 71,012,290$ \\
\hline 2015 & Jennings & us 50 & From West UAB of North Vernon to East UAB of North Vernon & North Vernon & Seymour & 259 & $\$ 27,216,07$ \\
\hline
\end{tabular}

Figure 18

\begin{tabular}{|c|c|c|c|c|c|c|}
\hline Letting Date & County & Road & Location & Note on Location & District & Type of Work \\
\hline $8 / 8 / 2007$ & Hancock & SR 238 & From jet SR 13 to $1-69$ & Fortville to $1-69$ & Greenfield & Road Rehabilitation (3R/4R Standards) \\
\hline $10 / 17 / 2007$ & Hancock & SR 9 & From Us 52 to $1-70$ & Greenfield to $1-74$ at shelbyville & Greenfield & HMA Overlay, Preventive Maintenance \\
\hline $11 / 19 / 2008$ & Hancock & SR 9 & $\begin{array}{l}\text { From } .53 \text { miles } N \text { of } 1-70 \text { (CR } 300 N \text { ) to } \\
\text { US36/SR67 }\end{array}$ & Huntsville to $1-70$ & Greenfield & Partial 3-R \\
\hline $7 / 23 / 2008$ & Henry & SR 109 & Bridge over $1-70$ & Knightstown exit of $1-70$ & ield & Bridge Rehabilitation or Repair \\
\hline 9/17/2008 & John & SR 44 & From I-65 to the WCL of Shelbyville & 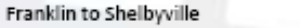 & & ition (3R/4R Standards) \\
\hline $12 / 10 / 2008$ & Marion & 1465 & Mainline us 40 & Indy by-pass & field & Added Travel Lanes \\
\hline $2 / 20 / 2008$ & Marion & 170 & $\begin{array}{l}\text { From } 1.88 \text { miles E of I- } 465 \text { to } 0.4 \text { miles } E \text { of } S R \\
9\end{array}$ & Indy to Greenfield & Greenfield & Pavement Repair Or Rehabilitation \\
\hline $9 / 17 / 2008$ & Shelby & SR 44 & Bridge over Sugar Creek, 3.61 miles E of 1-65 & Frankl & & Br Repl, C \\
\hline $9 / 17 / 2008$ & Shelby & SR 44 & Bridge over Gibson Ditch, 3.77 miles E of I-65 & Franklin to Shelbyville & ield & ed Culver \\
\hline $7 / 11 / 2007$ & Decatur & 174 & At US 421 & At Greensburg & bur & Modifi \\
\hline $7 / 11 / 2007$ & Decatur & 174 & At US 421 & At Greensburg & Seymour & Safety Revisions \\
\hline $12 / 12 / 2007$ & Franklin & 174 & SR 3 to Newpoint interchange & $\begin{array}{l}\text { From Greensburg south } \sim 8 \mathrm{mi} \\
\text { From 1-65 at Seymour to North }\end{array}$ & Seymour & HMA Overlay, Preventive Maintenance \\
\hline $11 / 28 / 2$ & Jenr & US 5 & US-31 t & Vernon & s & $P$ \\
\hline $8 / 22 / 2007$ & Johnson & 165 & SR-252 Interchange to Whitel and Road & $\mathrm{N}$ and $S$ of Franklin & Seymour & MA giverlay $P$ \\
\hline
\end{tabular}

The same questions as provided earlier apply:

- How will the planned projects affect average speeds to Greensburg?

- What projects will be necessary to get the speed limits to $50 \mathrm{mph}$ ?

- What will be the associated cost and completion time frame?

In order to answer these questions, we need data regarding the impact of projects from INDOT. This data has not been made available to the study team; hence these specific questions remain unanswered.

c. Hoosier Automotive Focus: Key suppliers unite to create a Hoosier automotive corridor supplying Toyota and Honda among others. This approach would provide an opportunity for true Indiana industry focused economic development. It would also enable existing or start-up businesses to have the opportunity to leverage multiple automotive manufacturers thereby permitting them to deal effectively with demand fluctuations, proving existing capabilities on one manufacturer before expanding. Shared suppliers are a preference in the Japanese automotive industry.

It could also enable consolidation of larger supplier facilities. It may enable outof-state locations to be consolidated into single Indiana-based location with better access to multiple key firms and finally permit significant overhead reduction, shared labor, and easier expansion potential. 


\section{Implications for INDOT}

-INDOT could choose to focus priority on projects that would specifically benefit the automotive industry, with exclusive emphasis in supporting Indiana economic development, with little "overflow" to other states.

\section{$\underline{\text { Risks }}$}

-Suppliers to Honda \& Toyota may feel pressure to not support one company or the other.

-Some speculation risk associated with improving geographic regions not intuitively obvious to the press in terms of economic development (would require a sales job to explain the benefit).

The map below shows the potential candidate region for a Hoosier automotive corridor (figure 19).

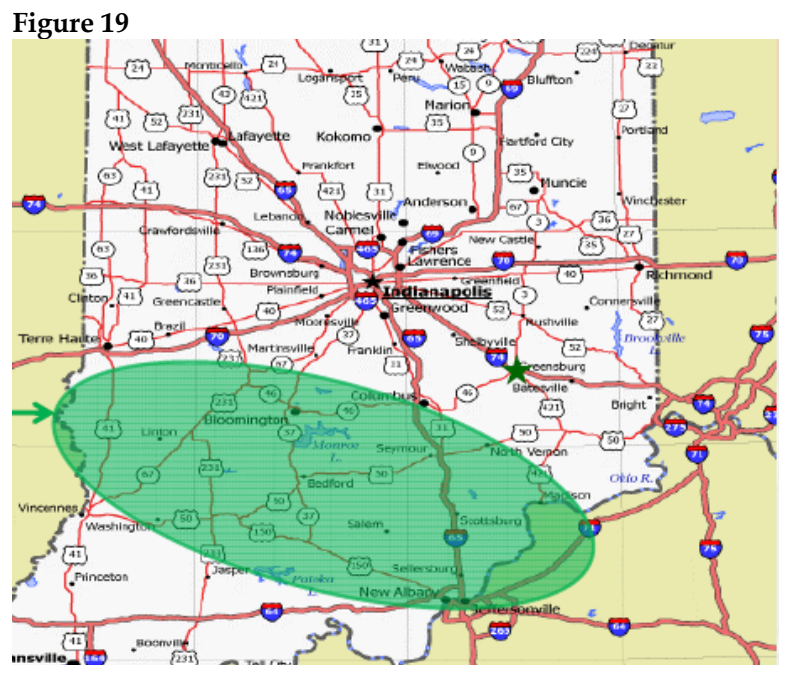

This region was identified by interviews with some Toyota managers and their supply base, discussions with Honda suppliers and prospective suppliers and determination that some overlap of the supply base did/could exist.

The corresponding cities that would be candidates for such plant locations are noted below (table 4).

Table 4

\begin{tabular}{|l|l|l|l|}
\hline City & Time (Mins) & Distance (MI) & $\begin{array}{l}\text { Average } \\
\text { Speed (MPH) }\end{array}$ \\
\hline Bedford & 105 & 78.68 & 44.96 \\
\hline Bloomington & 97 & 72.61 & 44.91 \\
\hline Columbus & 47 & 28.12 & 35.90 \\
\hline New Albany & 109 & 93.42 & 51.42 \\
\hline North Vernon & 48 & 29.46 & 36.83 \\
\hline Seymour & 64 & 43.42 & 40.71 \\
\hline Vincennes & 179 & 176.57 & 59.19 \\
\hline
\end{tabular}


A picture of this region with more detail is provided below (figure 20).

Figure 20

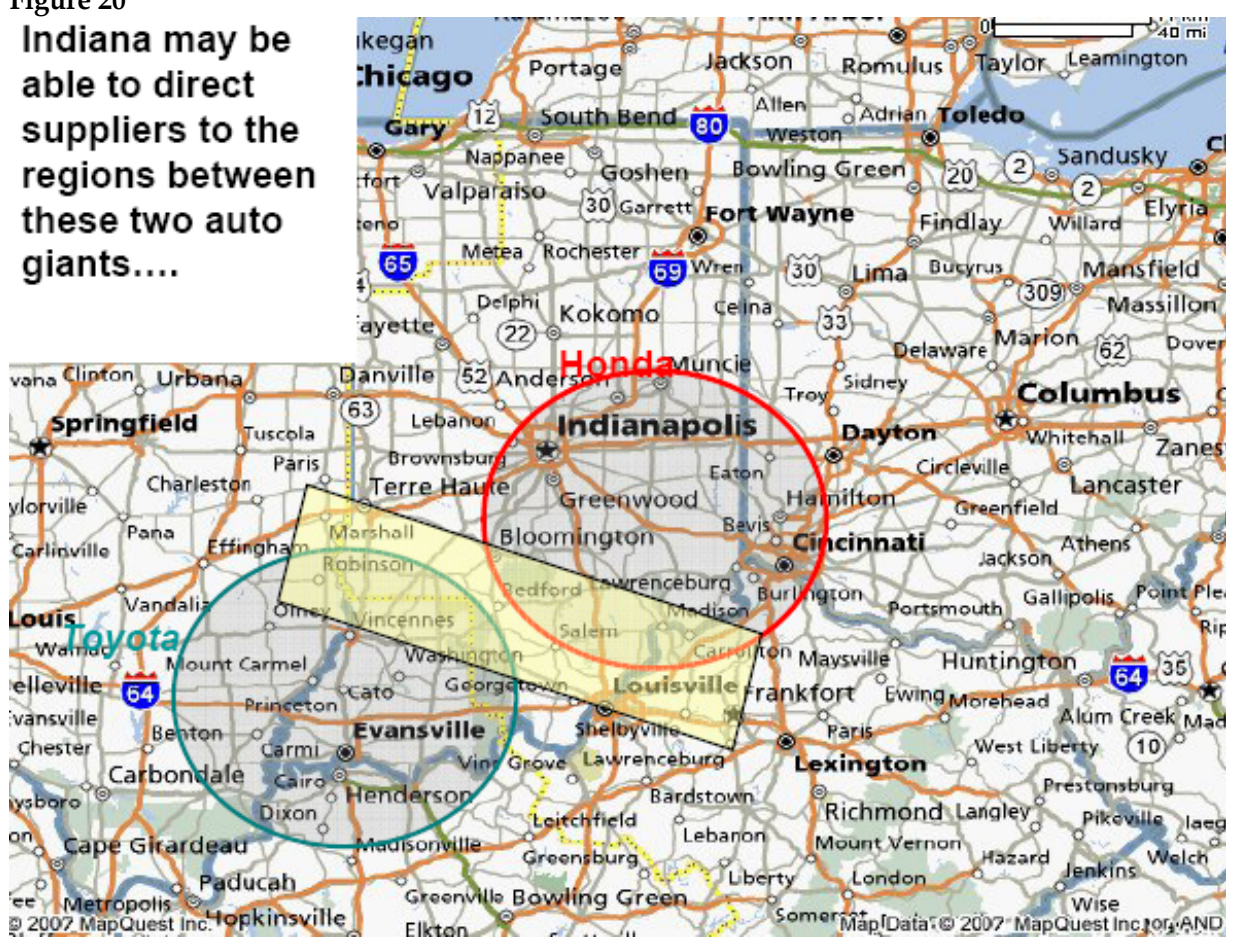

Projects under "Major Moves" and in the letting database that would affect this region are as follows (figure $21 \& 22$ ):

Figure 21

\begin{tabular}{|c|c|c|c|c|c|c|c|}
\hline Year & County & Route & Project Location & Note on Location & District & Project ID & cost \\
\hline 2007 & Hamilton & 169 & At 1-69 and SR 238 (Phase I) & Southwest side of Indy & Greenfield & 4 & $\$ 7,768,254$ \\
\hline 2010 & Marion & 1465 & At SR 37 (S jct) & Southwest side of Indy & Greenfield & 4 & $\$ 7,768,254$ \\
\hline 2014 & Marion & 169 & $\begin{array}{l}\text { From } 0.5 \mathrm{mi} \mathrm{S} \text { of } 1-465 \text { interchange ( } 75 \text { th St) to } 0.5 \mathrm{mi} \mathrm{S} \text { of } 96 \text { th St } \\
\text { Interchange } \\
\text { From } 0.5 \mathrm{mi} \mathrm{S} \text { of } 1-465 \text { interchange ( } 75 \text { th St) to } 0.5 \mathrm{mi} \mathrm{S} \text { of } 96 \text { th St }\end{array}$ & Southwest side of Indy & Greenfield & 4 & $\$ 7,768,254$ \\
\hline 2015 & Marion & 169 & Interchange & Southwest side of Indy & Greenfield & 4 & $\$ 7,768,254$ \\
\hline 2009 & Various & 169 & New I 69 Evansville to Indianapolis & Southwest side of Indy & Greenfield & 4 & $\$ 7,768,254$ \\
\hline 2010 & Various & 169 & New I 69 Evansville to Indianapolis & Southwest side of Indy & Greenfield & 4 & $\$ 7,768,254$ \\
\hline 2011 & Various & 169 & New I 69 Evansville to Indianapolis & Southwest side of Indy & Greenfield & 4 & $\$ 7,768,254$ \\
\hline 2012 & Various & 169 & New I 69 Evansville to Indianapolis & Southwest side of Indy & Greenfield & 4 & $\$ 7,768,254$ \\
\hline 2013 & various & 169 & New I 69 Evansville to Indianapolis & Southwest side of Indy & Greenfield & 4 & $\$ 7,768,254$ \\
\hline 2014 & Various & 169 & New I 69 Evansville to Indianapolis & Southwest side of Indy & Greenfield & 4 & $\$ 7,768,254$ \\
\hline 2015 & various & 169 & New I 69 Evansville to Indianapolis & Southwest side of Indy & Greenfield & 4 & $\$ 7,768,254$ \\
\hline 2008 & Morgan & SR 39 & From 0.68 mile to 1.97 miles $\mathrm{N}$ of SR 37 & Martinsville & Seymour & 138 & $\$ 15,694,670$ \\
\hline
\end{tabular}

Figure 22

Letting Database (Out of 334 Projects in Identified Regions)

\begin{tabular}{|c|c|c|c|c|c|c|}
\hline Letting Date & county & Road & Location & Note on Location & District & Type of Work \\
\hline $8 / 8 / 2007$ & Hancock & SR 238 & From jct SR 13 to I-69 & Fortville to $1-69$ & Greenfield & $\begin{array}{l}\text { Road Rehabilitation (3R/4R } \\
\text { Standards) }\end{array}$ \\
\hline $11 / 28 / 2007$ & Jennings & us 50 & US-31 to Hayden Pike & $\begin{array}{l}\text { From } 1-65 \text { at Seymour to North } \\
\text { vernon }\end{array}$ & Seymour & Partial 3-R \\
\hline $10 / 16 / 2008$ & Lawrence & us 50 & US 50 from SR $37 \mathrm{~N}$ jct to "E" St in Bedford & Bedford & Vincennes & $\begin{array}{l}\text { HMA Overlay, Preventive } \\
\text { Maintenance }\end{array}$ \\
\hline
\end{tabular}


As in earlier cases, important questions for INDOT are as follows:

- How will the planned projects affect average speeds to Greensburg?

- What projects will be necessary to get the speed limits to $50 \mathrm{mph}$ ?

- What will be the associated cost and completion time frame?

In order to answer these questions, we need data regarding the impact of projects from INDOT. This data has not been made available to the study team; hence these specific questions remain unanswered.

d. Ohio Focus: Supply the Greensburg operation with a few existing/newly established Indiana suppliers $(20 \%)$, with the balance supplied from existing Ohio partners $(80 \%)$.

\section{Implication for INDOT}

-Little local disruption beyond that already publicly discussed or $\underline{\text { Risks }}$ underway with state and local INDOT projects.

-Ohio aggressively competes with Indiana for business development and pre-empts Indiana economic development through incentives and better transportation alternatives.

The map below (figure 23) identifies the region that would be the focus of this approach.

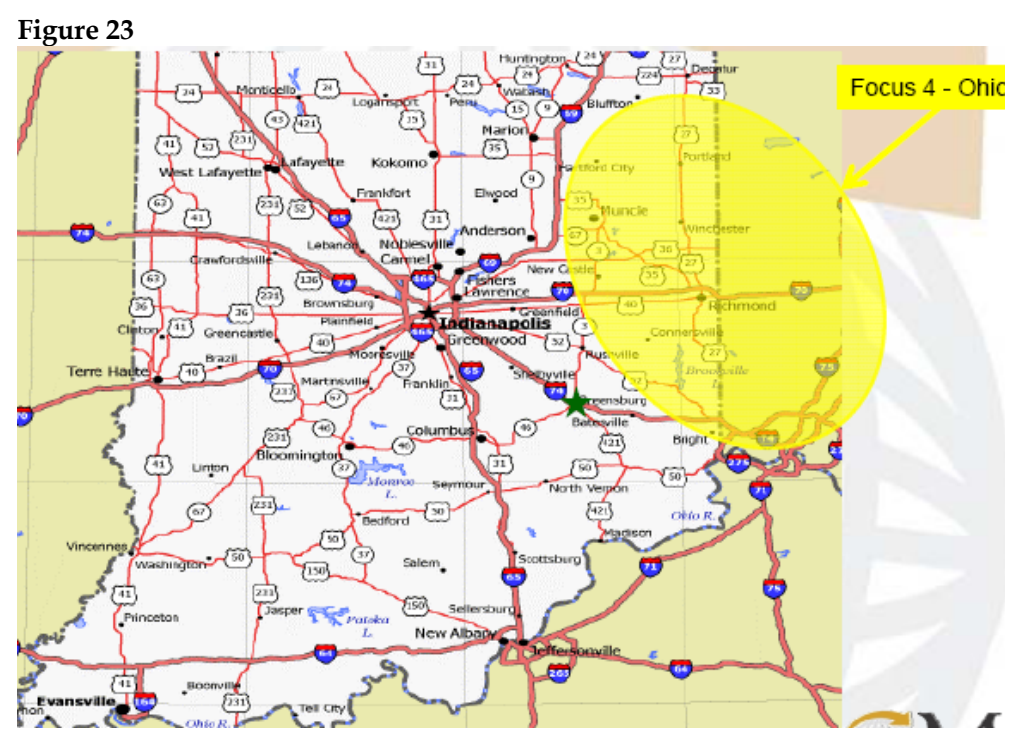


The specific towns that would be affected by this approach are as follows (table 5):

Table 5

\begin{tabular}{|l|l|l|l|}
\hline City & Time (Mins) & Distance (MI) & $\begin{array}{l}\text { Average } \\
\text { Speed (MPH) }\end{array}$ \\
\hline Brookville & 47 & 41.42 & 52.88 \\
\hline Connersville & 55 & 35.97 & 39.24 \\
\hline Liberty & 70 & 58.32 & 49.99 \\
\hline Muncie & 97 & 62.81 & 38.85 \\
\hline Richmond & 89 & 69.23 & 46.67 \\
\hline Winchester & 108 & 82.98 & 46.10 \\
\hline
\end{tabular}

These regions were identified following the details provided in phase 1 of the project analysis. The implied projects under "Major Moves" and in the letting database are as follows (figure $24 \& 25$ ):

Figure 24

\begin{tabular}{|c|c|c|c|c|c|c|c|}
\hline & & & & & & & \\
\hline & & & loves New Constru & ut or 209 ilsted pr & ects) & & \\
\hline Year & county & Route & Project Location & Note on Location & District & Project ID & cost \\
\hline 2009 & Hancock & 170 & At Mt comfort Rd, 7.7 miles $W$ of SR 9 (phase II) & Close eastern suburbs of Indy & Greenfield & 25 & $\$ 25,636,128$ \\
\hline 2014 & Hancock & 170 & From 0.5 miles E of Mt Comfort Rd to 0.8 miles E of & Close eastern suburbs of Indy & Greenfield & 292 & $\$ 71,012,290$ \\
\hline 2010 & Marion & 1465 & 1-70 interchange \& 1-465 mainline & East side of Indy & Greenfield & 1 & $\$ 72,363,798$ \\
\hline 2011 & Marion & 1465 & 1-74 / US 136 Intrchge \& mainline (encumbr. 1) & Southeast side of Indy & Greenfield & 1 & $\$ 34,951,715$ \\
\hline 2012 & Marion & 1465 & 1-74 / US 136 Intrchge \& mainline (encumbr. 2) & Southeast side of Indy & Greenfield & 1 & $\$ 34,951,715$ \\
\hline 2013 & Marion & 1465 & 1-74 / US 136 intrchge \& mainline (encumbr. 3) & Southeast side of Indy & Greenfield & 1 & $\$ 34,951,715$ \\
\hline 2013 & Marion & 170 & From $0.6 \mathrm{mi} E$ of Post Road to $0.5 \mathrm{mi} \mathrm{E}$ of Mt Comfort Road & Close eastern suburbs of Indy & Gree & 292 & \\
\hline 2007 & Franklin & SR 229 & From $1-74$ to & Bate & Sey & 89 & 180 \\
\hline 2014 & Jackson & US 50 & From US & & & 25 & \\
\hline 2015 & Jennings & us 50 & From West UAB of North Vernon to East UAB of North Vernon & North Vernon & Seymour & 259 & $\$ 27,216,073$ \\
\hline
\end{tabular}

Figure 25

\begin{tabular}{|c|c|c|c|c|c|c|}
\hline \multirow{2}{*}{\multicolumn{2}{|c|}{ igu }} & \multirow{2}{*}{\multicolumn{4}{|c|}{ Letting Database (Out of 334 Projects in Identified Regions) }} & \multirow[b]{3}{*}{ Type of Work } \\
\hline & & & & & & \\
\hline Letting Date & County & Road & Location & Note on Location & District & \\
\hline $10 / 17 / 2007$ & Hancock & SR 9 & From US 52 to $1-70$ & Greenfield to $1-74$ at Shelbyville & Greenfield & HMA Overlay, Preventive Maintenance \\
\hline $9 / 17 / 2008$ & Johnson & SR 44 & From $1-65$ to the WCL of Shelbyville & Franklin to Shelbyville & Greenfield & Road Rehabilitation (3R/4R Standards) \\
\hline $4 / 16 / 2008$ & Marion & 1465 & From Fall Creek to 1-74 & Indy by-pass & Greenfield & PCCP Patching \\
\hline $12 / 10 / 2008$ & Marion & 1465 & Mainline US 40 & Indy by-pass & Greenfield & Added Travel Lanes \\
\hline $2 / 20 / 2008$ & Marion & 170 & $\begin{array}{l}\text { From } 1.88 \text { miles E of I-465 to } 0.4 \text { miles E of SR } \\
9\end{array}$ & Indy to Greenfield & Greenfield & Pavement Repair or Rehabilitation \\
\hline $2 / 20 / 2008$ & Shelby & SR 244 & From $1-74$ to $S R 3$ & East off of $1-74$ just $S$ of $S h$ & Greenfield & Partial 3-R \\
\hline 9/17/2008 & shelby & SR 44 & Bridge over Sugar Creek, 3.61 miles E of 1-65 & Franklin to Shelbyville & Greenfield & Br Repl, Comp.Cont.Pres.Conc. I-Beam \\
\hline $9 / 17 / 2008$ & Shelby & SR 44 & Bridge over Gibson Ditch, 3.77 miles E of $1-65$ & Franklin to Shelbyville & Greenfield & Br Repl, Precast 3 sided Culvert \\
\hline $7 / 11 / 2007$ & Decatur & 174 & At US 421 & At Greensburg & Seymour & Interchange Modification \\
\hline $7 / 11 / 2007$ & Decatur & 174 & At US 421 & At Greensburg & seymour & Safety Revisions \\
\hline $7 / 11 / 2007$ & Decatur & US 421 & 174 & Honda Plant & Seymour & New Bridge Special Construction \\
\hline $7 / 11 / 2007$ & Decatur & US 421 & At $1-74$ & Honda Plant & seymour & New Bridge Special Construction \\
\hline $12 / 12 / 2007$ & Franklin & 174 & SR 3 to Newpoint interchange & From Greensburg south $\sim 8 \mathrm{mi}$ & seymour & HMA Overlay, Preventive Maintenance \\
\hline $11 / 28 / 2007$ & Jennings & us 50 & US-31 to Hayden Pike & $\begin{array}{l}\text { From 1-65 at Seymour to North } \\
\text { Vernon }\end{array}$ & Seymour & Partial 3-R \\
\hline $8 / 22 / 2007$ & Johnson & 165 & SR-252 Interchange to Whiteland Road & $\mathrm{N}$ and $\mathrm{S}$ of Franklin & Seymour & HMA Overlay, Preventive Maintenance \\
\hline
\end{tabular}

In this case, we still need INDOT to consider the following issues:

- How will the planned projects affect average speeds to Greensburg?

- What projects will be necessary to get the speed limits to $50 \mathrm{mph}$ ?

- What will be the associated cost and completion time frame?

In order to answer these questions, we need data regarding the impact of projects from INDOT. This data has not been made available to the study team; hence these specific questions remain unanswered. 
e. Rail Access Focus: The idea is that key improvements to CIND lines and access routes will result in a greater than expected supply exchange by rail.

The associated region was identified by first examining known improvements underway for rail lines into and around the Greensburg area. This was then combined with data collection regarding existing lines with quick connection to CIND. Finally we identify supplier types that could potentially utilize rail for their primary means of transport by determining locations within a short distance of the primary rail line

\section{Implication for INDOT}

-INDOT can choose to support smaller local projects along the improved rail line in support of CIND requiring low marginal

\section{$\underline{\text { Risks }}$} investment

-Transportation issues related to rail ownership \& access to CINDY.

-Rail not most cost effective for low cost/light weight components.

-Component deliveries tied to rail shipping performance, which lacks historic reliability.

-If only strategy, no effective supply line competition (monopoly) which is not effective for Indiana

The CIND line and the associated region is as follows (figure 26):

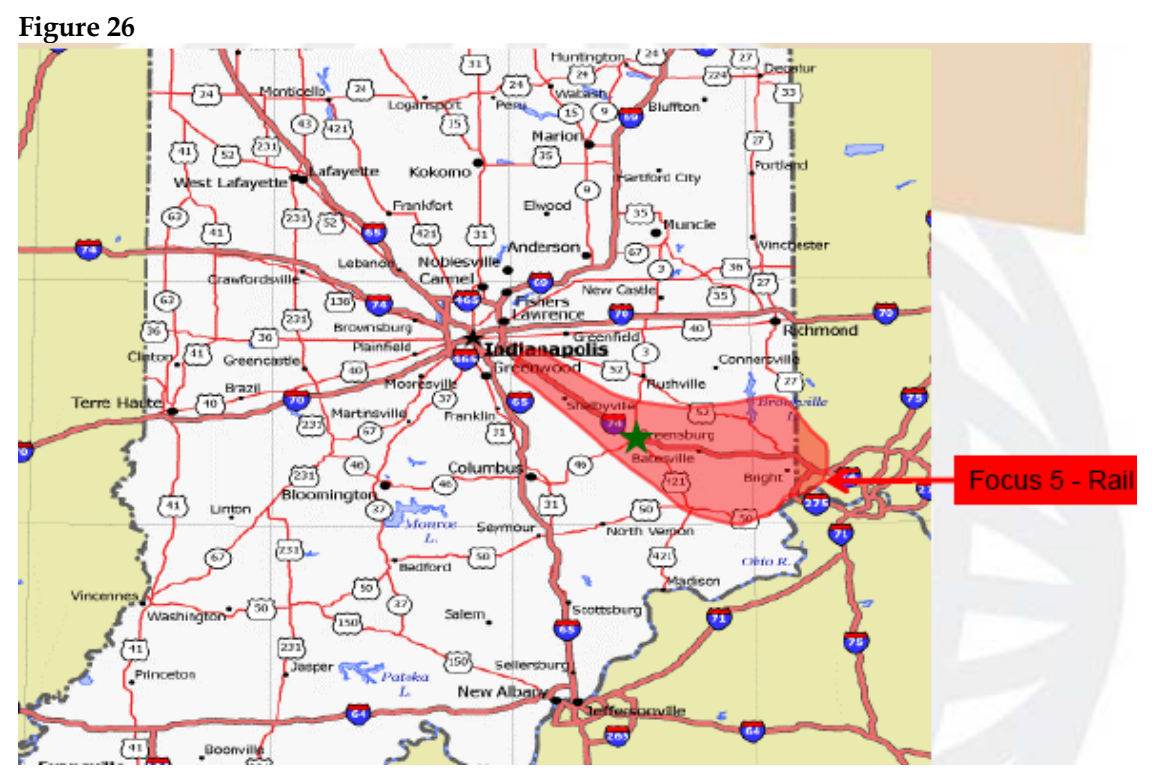


The towns that are affected by this strategy are as follows (table 6):

Table 6

\begin{tabular}{|l|l|l|l|}
\hline City & Time (Mins) & Distance (MI) & $\begin{array}{l}\text { Average Speed } \\
\text { (MPH) }\end{array}$ \\
\hline Batesville & 20 & 15.99 & 47.97 \\
\hline Brookville & 47 & 41.42 & 52.88 \\
\hline Greenfield & 48 & 38.52 & 48.15 \\
\hline Harrison, OH & 42 & 38.55 & 55.07 \\
\hline Indianapolis & 55 & 51.98 & 56.71 \\
\hline Liberty & 70 & 58.32 & 49.99 \\
\hline
\end{tabular}

The projects under "Major Moves" and the letting database are as follows (figure 27):

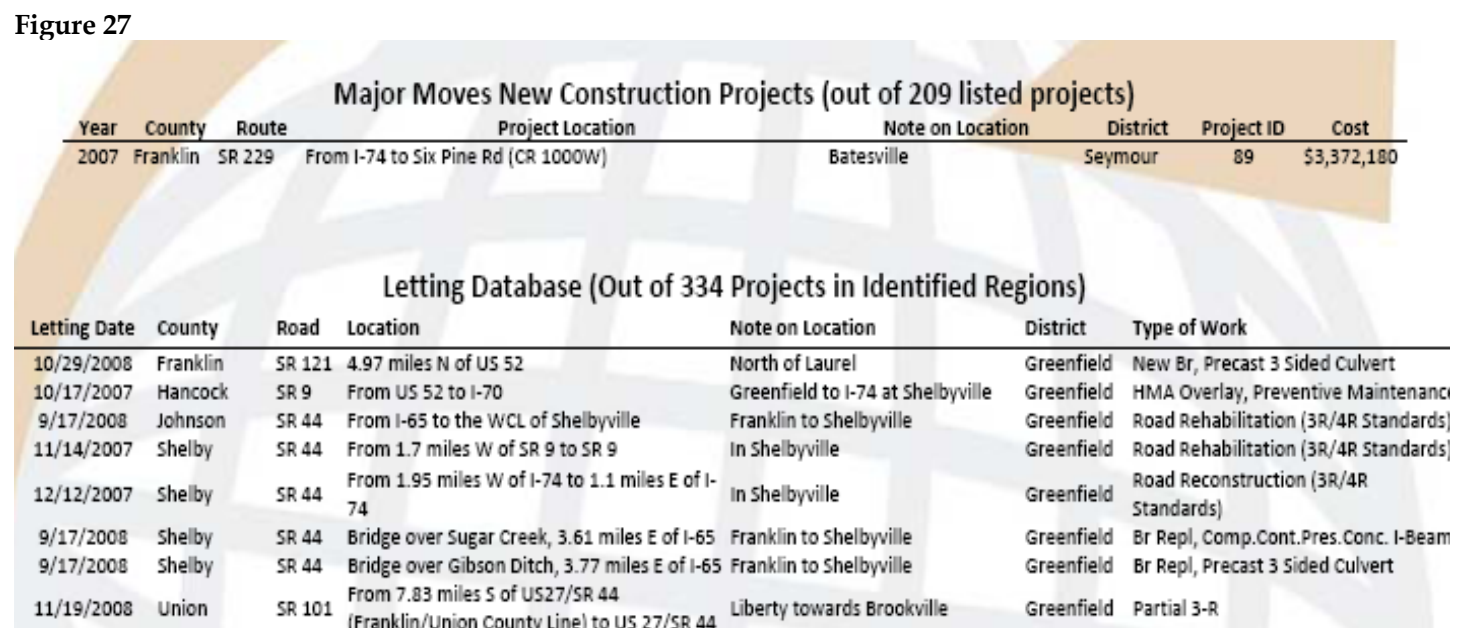

The questions for INDOT remain the following:

- How will the planned projects affect average speeds to Greensburg?

- What projects will be necessary to get the speed limits to $50 \mathrm{mph}$ ?

- What will be the associated cost and completion time frame?

In order to answer these questions, we need data regarding the impact of projects from INDOT. This data has not been made available to the study team; hence these specific questions remain unanswered. 
Phase 3: Completed and presented in July 2008

In this phase, we took a detailed look at Honda's North American supply chain. A snapshot of the products and plant locations is shown below ${ }^{4}$ (figure 28).

Figure 28

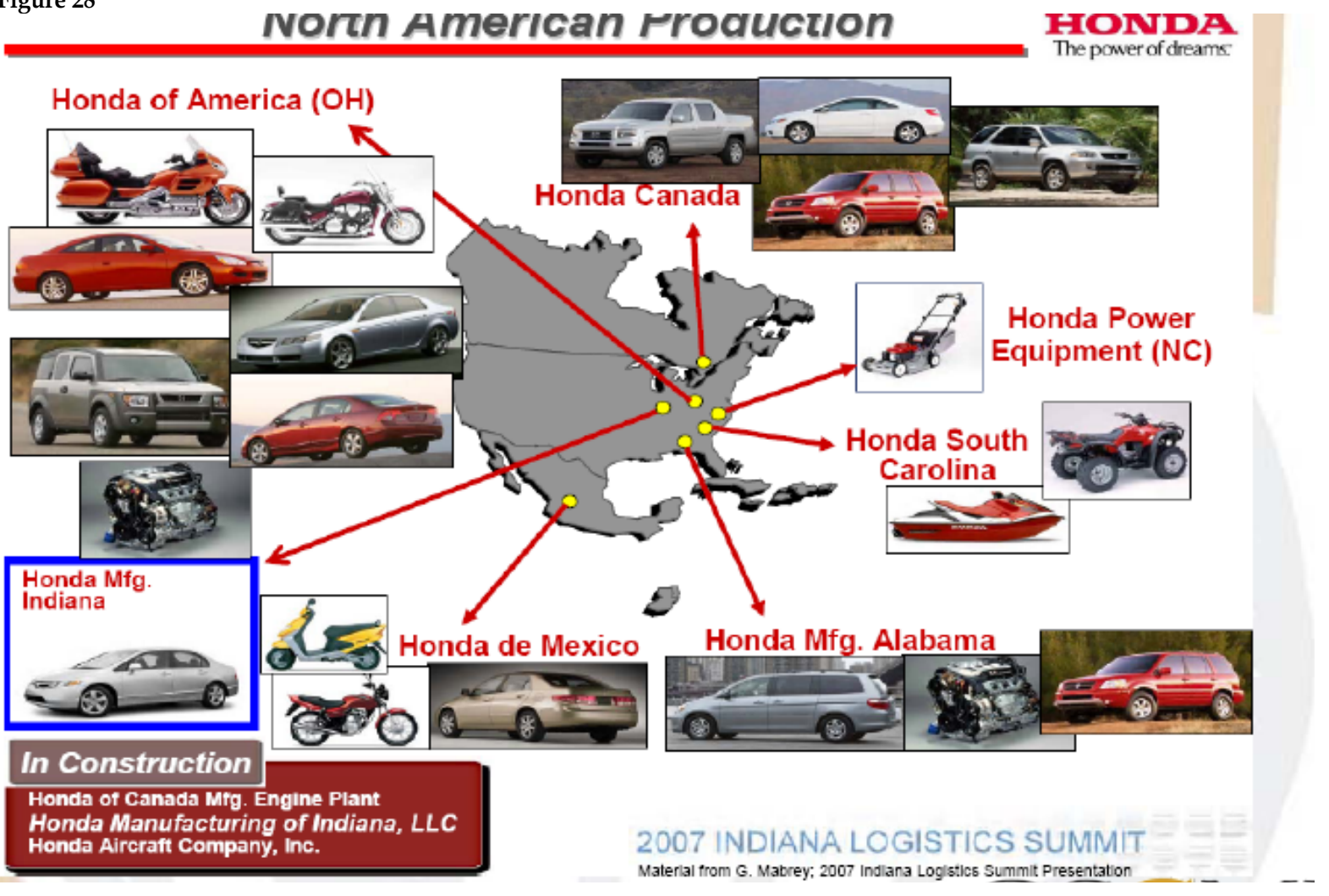

Note the variety of models produced across locations in the US and Canada. In addition, a close look at the layout of the new Honda plant in Greensburg is shown below ${ }^{4}$ (figure 29).

Figure 29

Note that given this layout, we can conclude that Honda will manufacture plastics, stamping etc. in house, but complete finished goods assembly with all other components purchased outside.

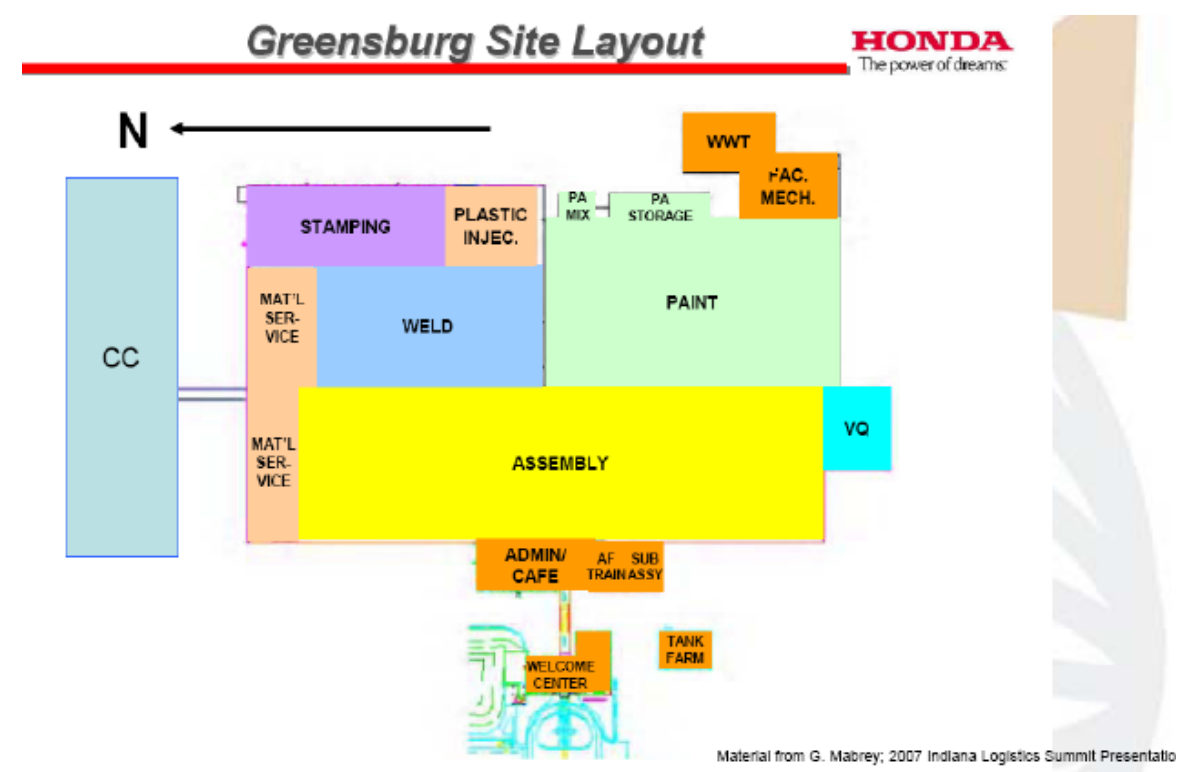


The "standard" Honda supply chain uses a tiered structure as shown below (figure $30)$.

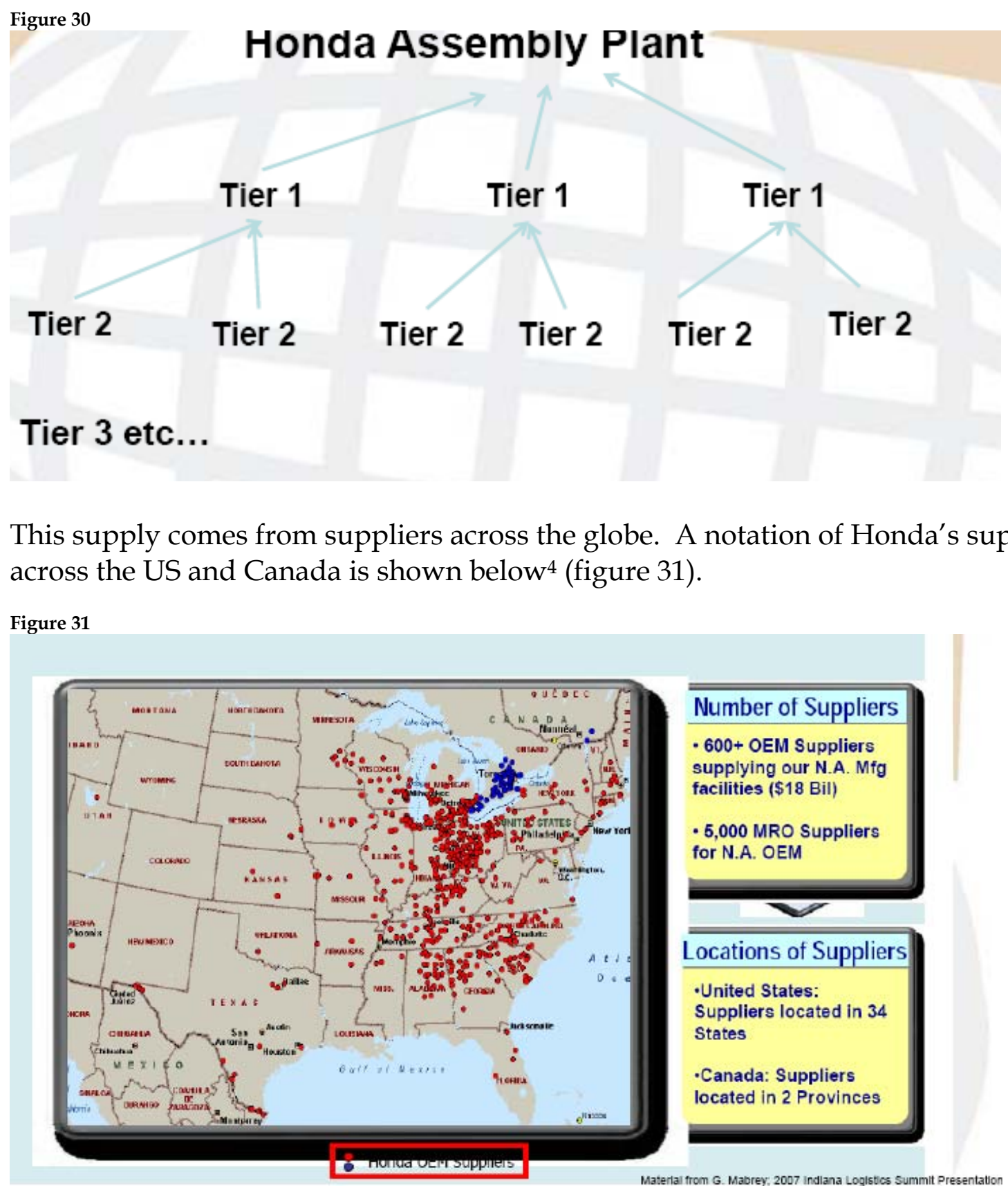

Honda has already announced the following decisions:

- Marysville and East Liberty, $\mathrm{OH}$ will continue to be assembly plants.

- Anna, $\mathrm{OH}$ which makes engines and Russell's Point which makes transmissions (will continue)

- A new engine plant in Canada to supply Canadian plants reduces Anna's by 200,000

- Anna's capacity can supply Greensburg with engines 
- Russell's Point has the capacity to supply US and Canada with transmissions

- New Seat plant in New Castle

- Plastics etc. in house

If we examine the capacity at the engine and transmission plants in Ohio, we see the following (table 7):

\begin{tabular}{|c|c|c|c|c|c|}
\hline $\begin{array}{l}\text { Name of } \\
\text { Plant }\end{array}$ & $\begin{array}{l}\text { Plant } \\
\text { Size }\end{array}$ & $\begin{array}{l}\text { Capital } \\
\text { Investment }\end{array}$ & Associates & Capacity & Products \\
\hline $\begin{array}{l}\text { Anna } \\
\text { Ohio } \\
\text { (Opened } \\
\text { July } \\
1985 \text { ) }\end{array}$ & $\begin{array}{l}1.6 \mathrm{M} \\
\text { sqft }\end{array}$ & $\$ 1.3 \mathrm{~B}$ & 2800 & $\begin{array}{l}1.16 \mathrm{M} \\
\text { engines/y } \\
\text { ear }\end{array}$ & $\begin{array}{l}\text { 4-Cylinder Engines for } \\
\text { Accord, Civic, Element, } \\
\text { CR-V, RDX; V6 Engines } \\
\text { for Accord, TL, MDX, } \\
\text { Pilot, Ridgeline; other } \\
\text { components }\end{array}$ \\
\hline $\begin{array}{l}\text { Russells } \\
\text { Point } \\
\text { Ohio }\end{array}$ & $\begin{array}{l}0.6 \mathrm{M} \\
\text { sqft }\end{array}$ & $\$ 325 \mathrm{M}$ & 930 & $\begin{array}{l}1 \mathrm{M} \\
\text { Transmiss } \\
\text { ions/year }\end{array}$ & $\begin{array}{l}\text { Automatic Transmissions } \\
\text { for Accord, TL, MDX, } \\
\text { Odyssey, Civic, Pilot, } \\
\text { Element, CR-V, RDX }\end{array}$ \\
\hline $\begin{array}{l}\text { (Opened } \\
1982 \text { ) }\end{array}$ & & & & & \\
\hline
\end{tabular}

Given these tier 1 plant capacities and North American Honda car production, we conclude the following likely scenarios:

- Honda Tier 1 plants in Anna, $\mathrm{OH}$ and Russell's Point, $\mathrm{OH}$ will supply engines and transmissions to Greensburg

- TS Tech in Rushville will provide seats - sequence supplier

- Plastics and stamping done in house at Greensburg

- Other Tier 1's (locations unknown) will supply Greensburg (e.g. axles)

- Indiana Tier 2 suppliers for engines and transmissions will supply Anna and Russell's Point as before

- New suppliers to TS Tech will supply to New Castle

But, according to Kim Hill from the Center for Automotive Research ${ }^{5}$,

- 4.7 times jobs will develop outside the plant.

- Every other Honda facility in North America has a second "sister" facility on its campus; it makes sense for Greensburg as well. 
- A second "sister" facility will come in the form of a new engine plant in Greensburg, if the Honda FIT is made in Greensburg (currently all Honda FITs are imported from Japan)

- Jobs will also develop outside of the supply chain through normal economic development (such as hotels near the plant, restaurants, etc).

Given this supply chain perspective, we have to revise our previous scenarios to include flows from Indiana to Ohio tier 1 suppliers and flows directly to Greensburg as well as tier 1 flows to Indiana suppliers. This supply chain perspective results in a very different set of conclusions.

In this phase, we completed interviews and survey data collection from 51 sources (see apndx. 6). These sources included suppliers, Honda personnel, Toyota personnel, auto industry consultants, area economic development officials and INDOT personnel. Other data sources included the Indiana Manufacturing Association database, academic sources and industry publications. A summary of the source information is shown below (table 8).

Table 8

\begin{tabular}{|c|c|}
\hline Category & Number Interviewed \\
\hline Tier 1 & 17 \\
\hline Engine and Transmission & 4 \\
\hline Tier 2 & 10 \\
\hline Others & 20 \\
\hline & $\mathbf{5 1}$ \\
\hline
\end{tabular}

The supplier locations are mapped below (figure 32) (see apndx.6).

Figure 32

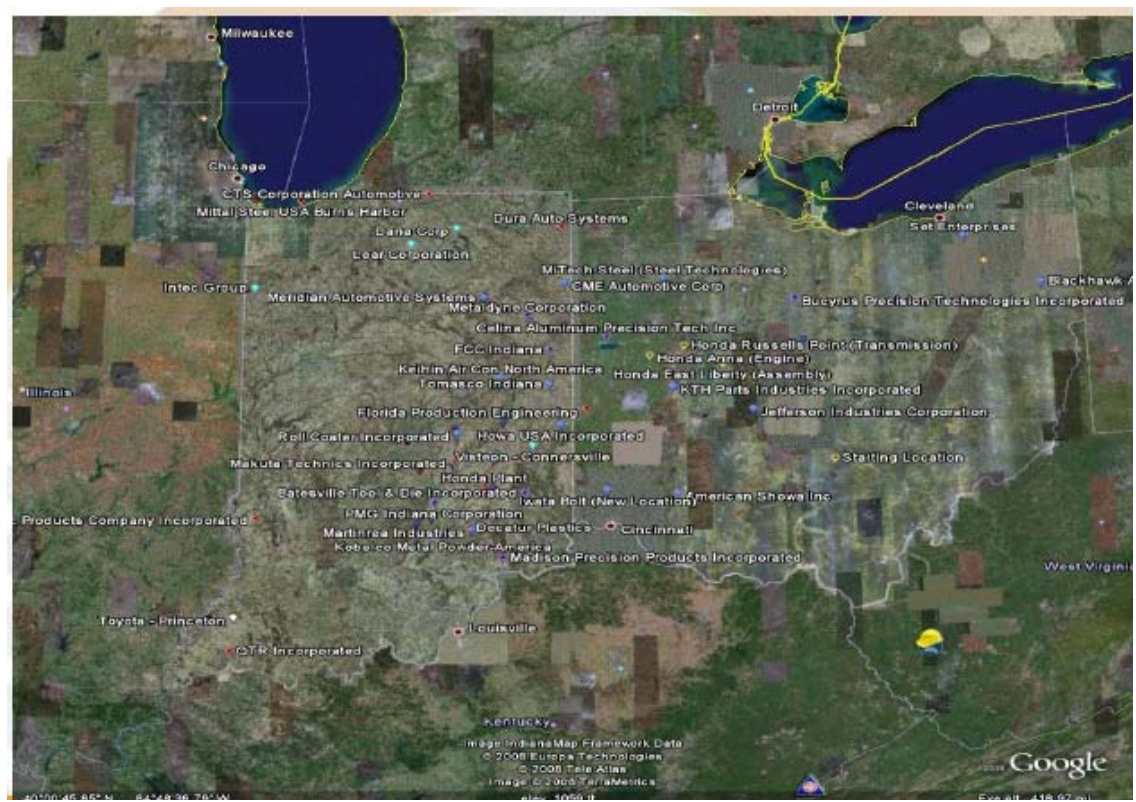




\section{INDOT Personnel Feedback ${ }^{6}$ :}

- District INDOT's are most connected with IEDC's, not local EDC's.

- District INDOT's tend to focus on spot improvements; strategy related to Honda deferred to INDOT Central.

- Central INDOT planning tends to control project selection; district INDOT has some project priority flexibility.

It remained unclear if there is a single point of contact that coordinates county and municipal projects with INDOT projects to deliver end to end performance improvements for companies.

\section{LEDO/ EDC feedback ${ }^{6}$ :}

- Unemployment too low in the region to attract new employers

- Belief that Honda Effect will be a delayed reaction; therefore muting economic development today

- Suppliers waiting for $2^{\text {nd }}$ line/ramp up production

- We have our share of economic development

- Not enough shovel ready real estate

- Too many little building sites - not enough large

- Too close or too far away from Honda

We will next focus on feedback from specific suppliers, however, in order to do so, we will return to three of the five possible focus areas discussed in the previous phase. These are listed below by specific road segment

- SR 3 is underutilized, needs connector to I-69. A bypass to avoid SR-3 \& Rushville which adds 15 minutes to the trip.

- SR 3 from New Castle to Rushville with bypass around Rushville "East Central Indiana Corridor"

- SR 9 needs to be improved as it is already very crowded. Lots of commuter traffic on SR 9 south from Anderson and Muncie.

- US 27 from Winchester to I-70

- SR 44 west of Franklin and from Shelbyville to Rushville and down to Greensburg a possibility

- SR 58 and I-65 interchange congested

- US 50 congested due to Army National Guard Muscatatuck Urban Training Center near Butlerville

- SR 44 between Franklin and Shelbyville meets a major bottleneck at Shelbyville and requires a bypass.

- I-70 volume of traffic

- A four lane route between I-65 and I-74 and also to I-70 would be very effective otherwise bypass routes through smaller cities are required.

- Fix 421 near Greensburg 
Notice that the majority of suggested projects focus on SR 9, SR 3, SR 27, SR 44, SR 46 and SR 50 (figure 33).

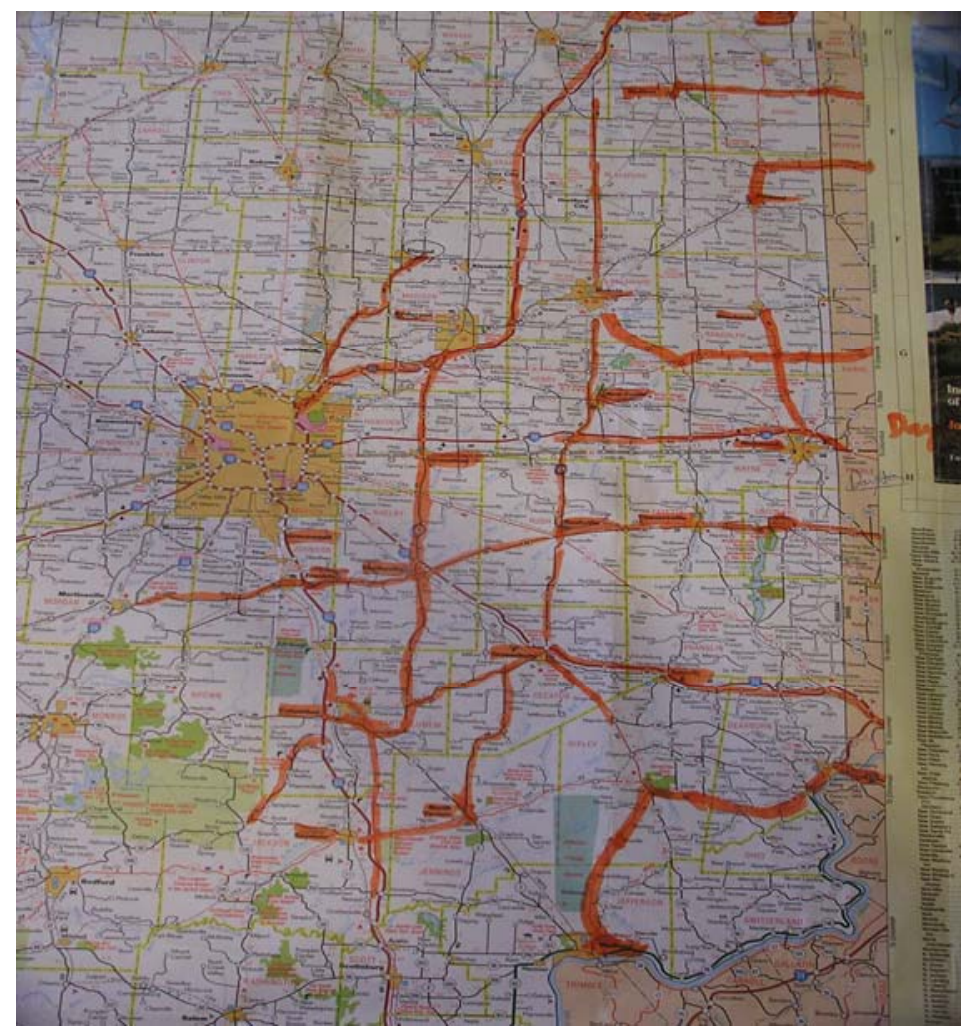

A close examination of the "Major Moves" project list (figure 34, 35, 36, 37, 38, \& 39) shows the following projects that are related to these suggested roads.

\section{SR 9 Related Major Moves projects}

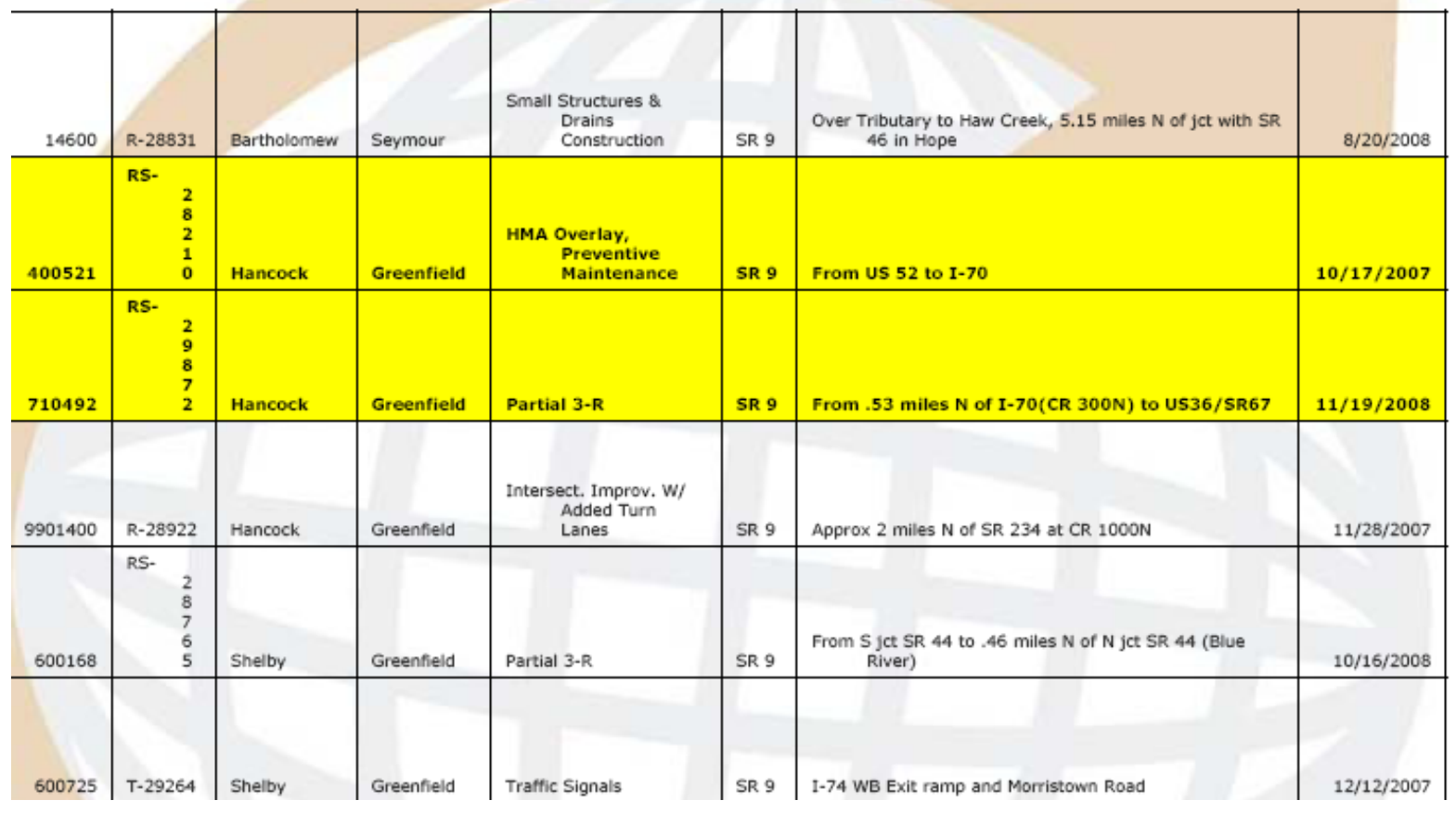

Figure 35 


\section{SR 3 Related Major Moves projects}

\begin{tabular}{|c|c|c|c|c|c|c|c|}
\hline 600 & $\begin{array}{l}4 \\
2 \\
5 R S-29170\end{array}$ & Decatur & Seymour & PCCP Patching & SR 3 & W jct SR 46/3 to Muddy Fork Sand Creek Bridge & $12 / 12 / 2007$ \\
\hline 600 & $\begin{array}{l}5 \\
6 \\
5 R S-29170\end{array}$ & Decatur & Seymour & PCCP Patching & SR 3 & $\begin{array}{l}\text { Muddy Fork Sand Creek bridge to } 2 / 4 \text { lane } \\
\text { transition }\end{array}$ & $12 / 12 / 2007$ \\
\hline 710 & $\begin{array}{l}5 \\
1 \\
1 T-29890\end{array}$ & Henry & Greenfield & $\begin{array}{l}\text { Traffic Signals, New Or } \\
\text { Modernized }\end{array}$ & SR 3 & 2.06 miles $N$ of $S R 38$ (CR 200N) & $11 / 19 / 2008$ \\
\hline 710 & $\begin{array}{l}5 \\
0 \\
0 \\
1 R S-29882\end{array}$ & Jefferson & Seymour & Partial 3-R & SR 3 & SR-356 to SR-250 & $3 / 5 / 2008$ \\
\hline 710 & $\begin{array}{l}5 \\
0 \\
2 \text { RS-29883 }\end{array}$ & Jennings & Seymour & Partial 3-R & SR 3 & S jct W/SR-7 S of Vernon to US-50 & $3 / 5 / 2008$ \\
\hline
\end{tabular}

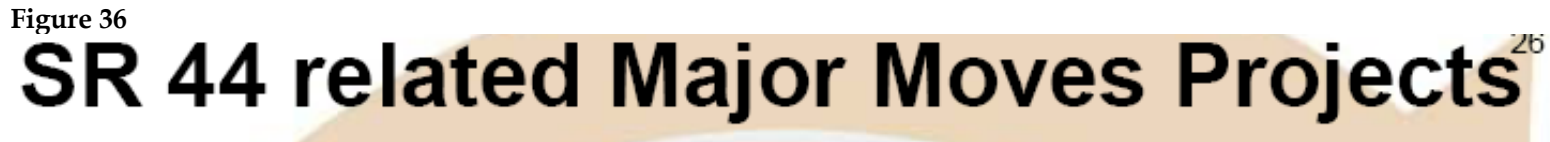

\begin{tabular}{|c|c|c|c|c|c|c|c|}
\hline 11830 & R-28527 & $\begin{array}{l}\text { Fayett } \\
\mathrm{e}\end{array}$ & Greenfiesd & Railroad Work & SR 44 & 0.01 mile E of SR 121 & $11 / 28 / 2007$ \\
\hline 300440 & $R-28527$ & $\begin{array}{l}\text { Fayett } \\
\text { e }\end{array}$ & Greenfiesd & Traffic Ssignals: Modernization & SR 44 & At Grand Avesuse & $11 / 28 / 2007$ \\
\hline 600617 & R-28527 & $\begin{array}{l}\text { Fayett } \\
\mathrm{e}\end{array}$ & Greenfiesd & Utility Resocation & SR 44 & $\begin{array}{l}\text { From 0.39 mike W of SR } 1 \text { (Western Ave) to SR } \\
1 \text { (Sth St) }\end{array}$ & $11 / 28 / 2007$ \\
\hline 9802590 & R-28527 & $\begin{array}{l}\text { Fayett } \\
\text { e }\end{array}$ & Greenfiekd & Pavernent Repair Or Rehubilitation & SR 44 & $\begin{array}{l}\text { From } 0.39 \text { mike W of SR } 1 \text { (Western Ave) to SR } \\
1 \text { (Sth St) }\end{array}$ & $11 / 28 / 2007$ \\
\hline 200539 & $R-29022$ & $\begin{array}{l}\text { Johnexo } \\
\text { n }\end{array}$ & Greenfiesd & Signing & SR 44 & From $1-65$ to the wa of Shelbyville & $9 / 17 / 2003$ \\
\hline 9610160 & R-29022 & $\begin{array}{l}\text { kohnex } \\
n\end{array}$ & Greenfiesd & Road Rehabilitation (3R/4R Standards) & $\operatorname{sR} 44$ & From $1-65$ to the wa of Shellbyville & $9 / 17 / 2003$ \\
\hline 101130 & R-29022 & $\begin{array}{l}\text { Johneso } \\
\text { n }\end{array}$ & Seymour & Brickge Dexk Overlay & SR 44 & Bridge over Suggar Creak Overflow & $9 / 17 / 2008$ \\
\hline 100451 & $R-28784$ & Rush & Greenfiesd & Small Structure Replacement & SR 44 & 1.45 miles E of SR 3 & $10 / 29 / 2003$ \\
\hline 100452 & R-28784 & Rush & Greenfiesd & Simall Structure Replacement & SR 44 & 1.65 miles E of SR 3 & $10 / 29 / 2008$ \\
\hline 200245 & R-28985 & Rush & Greenfiesd & Traffic Signals: Modernization & SR 44 & At Sexond Street and Main Street & $12 / 12 / 2007$ \\
\hline 200246 & R-20985 & Rush & Greenfiesd & Sign Modernization (Series of Units) & SR 44 & From 0.68 mile W of SR 3 to 0.18 mile E of SR 3 & $12 / 12 / 2007$ \\
\hline 9706570 & R-28985 & Rush & Greenfiekd & Road Pehabilitation (3R/4R Standards) & SR 44 & From 0.68 mile W of SR 3 to 0.18 mile E of SR 3 & $12 / 12 / 2007$ \\
\hline 100325 & R-20022 & Shellby & Greenfiedd & Br Reppl, Comp.Cont.Pres.Conci. I-Bearn & SR 44 & Brickge over Suggar Creek, 3.61 mikes E of $1-65$ & $9 / 17 / 2008$ \\
\hline 100326 & R-20022 & Shellby & Greenfiedd & Br Repl, Precast 3 Sidked Culwert & SR 44 & Bridge over Gibson Ditch, 3.77 miles E of $1-65$ & $9 / 17 / 2008$ \\
\hline 100447 & R-28794 & Shellby & Greenfiekd & Sirsall Structure Repkicernent & SR 44 & 4.74 miles $E$ of $1-74$ & $4 / 16 / 2008$ \\
\hline 9704190 & $R-28945$ & Shellby & Greenfiekd & Road Rexonstruction (3R/4R Standards) & SR 44 & From 1.95 miks $W$ of $1-74$ to 1.1 mikes E of $1-74$ & $12 / 12 / 2007$ \\
\hline 9602530 & $R-28931$ & Shellby & Greenfiedd & Roxad Rehabilitation (3R/4R Standards) & SR 44 & From 1.7 miles W of SR 9 to SR 9 & $11 / 19 / 2003$ \\
\hline 0002534 & R-28931 & Shellby & Greenfiedd & Traffic Signale: Modernization & SR 44 & At Miller St & $11 / 19 / 2003$ \\
\hline $000253 x$ & $R-28931$ & Shellby & Greenfiesd & Sign Modernization (Series of Units) & SR 44 & From 1.7 miles W of SR 9 to SR 9 & $11 / 19 / 2008$ \\
\hline $990419 n$ & $R-28945$ & Shellby & Greenfiesd & Traffic Signale: Modernization & SR 44 & Various: & $12 / 12 / 2007$ \\
\hline
\end{tabular}


Figure 37

\section{SR 46 related Major Moves}

\begin{tabular}{|c|c|c|c|c|c|c|c|}
\hline 600488 & $\begin{array}{l}\text { R- } \\
29354\end{array}$ & Bartholomew & Seymour & Pipe Lining & SR 46 & $3.45 \mathrm{~m} \mathrm{~W}$ of $1-65$ & $1 / 9 / 2008$ \\
\hline 710337 & $\begin{array}{l}\text { IR- } \\
29450\end{array}$ & Bartholomew & Seymour & $\begin{array}{l}\text { Signs, Lighting, Signals } \\
\text { And Markings }\end{array}$ & SR 46 & State St from Pence/Mapleton St to Marr Rd & $3 / 19 / 2008$ \\
\hline 9902930 & $\begin{array}{l}\text { IR- } \\
29450\end{array}$ & Bartholomew & Seymour & Median Construction & SR 46 & State St from Pence/Mapleton St to Marr Rd & $3 / 19 / 2008$ \\
\hline 300038 & $\begin{array}{l}\text { B. } \\
29190\end{array}$ & Brown & Seymour & $\begin{array}{l}\text { Bridge Deck } \\
\text { Reconstruction }\end{array}$ & SR 46 & $\begin{array}{l}\text { Bridge over North Fork Salt Creek, } 0.11 \text { mile } W \text { of } \\
\text { SR } 135\end{array}$ & $10 / 1 / 2008$ \\
\hline 600473 & $\begin{array}{l}\text { R- } \\
29354\end{array}$ & Brown & Seymour & Pipe Lining & SR 46 & SR 463.94 miles E Jct SR $46 / 135 \mathrm{~N}$ & $1 / 9 / 2008$ \\
\hline 710504 & $\begin{array}{l}\text { RS- } \\
29886\end{array}$ & Dearbom & Seymour & Partial 3-R & SR 46 & $S R-1$ to US-52 & $3 / 5 / 2008$ \\
\hline 8145550 & $\begin{array}{l}\text { R- } \\
29508\end{array}$ & Dearbom & Seymour & Slide Correction & SR 46 & At 2.8 miles W of US 52 at ECL of St Leon & $4 / 30 / 2008$ \\
\hline 600362 & $\begin{array}{l}\text { RS- } \\
28860\end{array}$ & Decatur & Seymour & Partial 3-R & SR 46 & From $E$ jct US $421 / S R \quad 46$ to $E$ Greensburg $C$. & $1 / 9 / 2008$ \\
\hline 600603 & $\begin{array}{l}\text { RS- } \\
29175\end{array}$ & Monroe & Seymour & Partial 3-R & SR 46 & College Mall Rd to SR-446 & $11 / 28 / 2007$ \\
\hline
\end{tabular}

Figure 38

\section{US 27 related Major Moves}

\begin{tabular}{|c|c|c|c|c|c|c|c|}
\hline 101134 & R-28772 & Union & Greenfield & Small Structure Replacement & US 27 & On CR $100 \mathrm{~S}$ just $\mathrm{S}$ of Hannah Creek Bridge & $11 / 28 / 2007$ \\
\hline 101135 & $R-28772$ & Union & Greenfield & Bridge Replacement, Concrete & US 27 & US 27 over Hannah Creek & $11 / 28 / 2007$ \\
\hline 101136 & R-28772 & Union & Greenfield & Signing & US 27 & From $6.14 \mathrm{~km} \mathrm{~S}$ of SR 44 to $1.29 \mathrm{~km} \mathrm{~S}$ of SR 44 & $11 / 28 / 2007$ \\
\hline 9901280 & $R-28772$ & Union & Greenfield & Road Rehabilitation (3R/4R Standards) & US 27 & Fr 3.81 I. S. of SR 44 to .31 S of SR 44 & $11 / 28 / 2007$ \\
\hline 400983 & $R-28149$ & Wayne & Greenfield & Traffic Signals Modernization & US 27 & At Locust Drive & $11 / 14 / 2007$ \\
\hline 710519 & $R-28149$ & Wayne & Greenfield & Utility Relocation & US 27 & From 2.06 mile $S$ of $1-70$ to 0.1 miles $S$ of $1-70$ & $11 / 14 / 2007$ \\
\hline 9502980 & $R-28149$ & Wayne & Greenfield & Median Construction & US 27 & From 2.06 mile $S$ of $1-70$ to 0.1 miles $S$ of $1-70$ & $11 / 14 / 2007$ \\
\hline $980297 \mathrm{~B}$ & $R-28149$ & Wayne & Greenfield & Traffic Signals Modernization & US 27 & At Sim Hodgin Parkway/Reid Hospital & $11 / 14 / 2007$ \\
\hline $980297 \mathrm{C}$ & $R-28149$ & Wayne & Greenfield & Traffic Signals Modernization & US 27 & At Waterfall Rd & $11 / 14 / 2007$ \\
\hline $980297 E$ & $R-28149$ & Wayne & Greenfield & Traffic Signals Modernization & us 27 & At Industries $\mathrm{Dr}$ & $11 / 14 / 2007$ \\
\hline $980297 \mathrm{~F}$ & $R-28149$ & Wayne & Greenfieild & Traffic Signals Modernization & US 27 & At IU E Dr & $11 / 14 / 2007$ \\
\hline $980298 \mathrm{w}$ & $R-28149$ & Wayne & Greenfield & Modernize Continuous Lighting & US 27 & From 0.1 mile $S$ jet of $1-70$ to 2.06 miles $S$ of $1-70$ & $11 / 14 / 2007$ \\
\hline $98 \mathrm{x}$ & $R-28149$ & iyne & Greenfield & Sign Modernization (S & US 27 & From 0.1 mile S & 2007 \\
\hline
\end{tabular}

Figure 39

\section{US 50 related Major Moves}

\begin{tabular}{|c|c|c|c|c|c|c|c|}
\hline 600604 & $\begin{array}{l}\text { RS } \\
29 \\
17 \\
6 \\
\end{array}$ & Jackson & Seymour & PCCP Patching & us 50 & .3 miles E of Agrico Lane to US-31 & $11 / 28 / 2007$ \\
\hline 600606 & $\begin{array}{l}\text { RS } \\
29 \\
17 \\
9\end{array}$ & Jennings & Seymour & HMA Overlay, Functional & us 50 & Hayden Pike to SR $3 / 7$ & $2 / 6 / 2008$ \\
\hline 600607 & $\begin{array}{l}\text { RS } \\
29 \\
17 \\
9\end{array}$ & Jennings & Seymour & Partial 3-R & us 50 & SR $3 / 7$ to Greensburg St & $2 / 6 / 2008$ \\
\hline 600739 & $\begin{array}{l}\text { RS } \\
29 \\
28 \\
7 \\
\end{array}$ & Jennings & Seymour & Partial 3-R & us 50 & US-31 to Hayden Pike & $11 / 28 / 2007$ \\
\hline 9902610 & $\begin{array}{l}\text { R- } \\
29 \\
\text { os } \\
4 \\
\end{array}$ & Jennings & Seymour & Intersection Improvement & us 50 & At Deer Creek Rd (CR 75E) & 9/6/2007 \\
\hline 400871 & $\begin{array}{l}\text { RS } \\
28 \\
66 \\
7 \\
\end{array}$ & Lawrence & Vincennes & $\begin{array}{l}\text { HMA Overlay, Preventive } \\
\text { Maintenance }\end{array}$ & us 50 & US 50 from SR $37 \mathrm{~N} \mathrm{jet} \mathrm{to} \mathrm{"} \mathrm{E}^{-} \mathrm{St}$ in Bedford & $10 / 16 / 2008$ \\
\hline 9611980 & $\begin{array}{l}8-2 \\
29 \\
30 \\
7\end{array}$ & Lawrence & Vincennes & Bridge Replacement & us so & $\begin{array}{l}\text { Bridge over S Fork Leatherwood Creek, } 2.26 \text { miles W } \\
\text { of SR } 446\end{array}$ & $3 / 19 / 2008$ \\
\hline
\end{tabular}


The main question remains identifying the link between these specific projects and their impact on travel times on these suggested roads. Perhaps it would be useful to consider all of these projects as part of an overall strategic initiative to develop Indiana automotive supply chains.

To examine this issue further, we return to our earlier discussion of specific themes around which these projects can be assessed. Based on the new data gathered, we reduce the number of possible themes to three, which will be discussed below.

1) Shared Supply Focus: Honda supplies Greensburg operation with a few existing/newly established Indiana suppliers (20\%), \& the balance from Ohio. Projects follow market evolution. The analysis of the shared supply focus remains the same as that provided in phase 1 and thus will remain unchanged.

2) Reclamation Focus: Key suppliers opportunistically backfill the US automotive industry generated void. Given this focus and possible affected plants, the implied roads that would have flows are the following (figure 40):

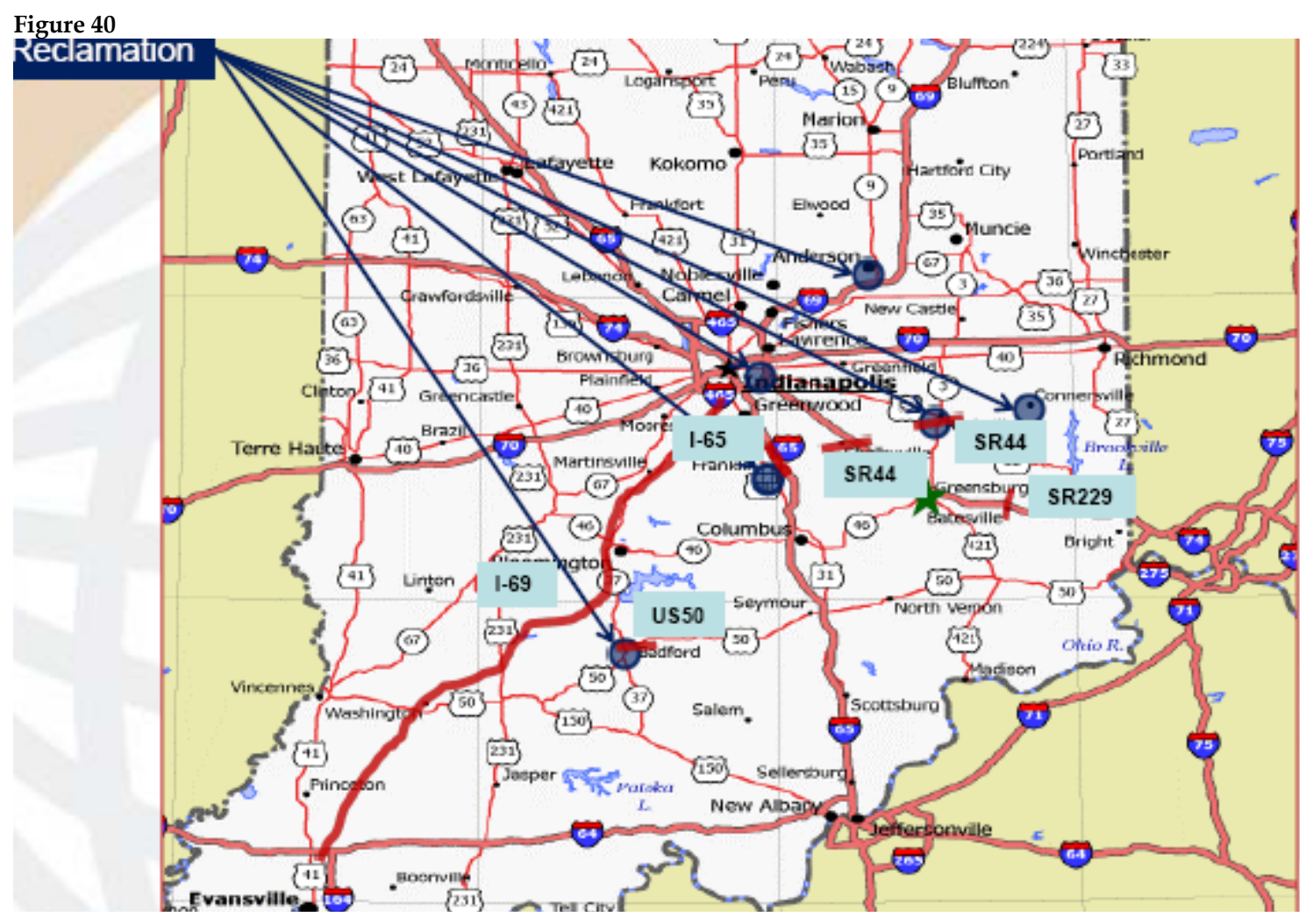


The average distances between these plants and possible supply to the Anna or Greensburg plant are as follows (table 9):

The average distances of these plants seem to make them uncompetitive. However, suppose each plant were to choose its product strategically so as to remain competitive as a

\begin{tabular}{|c|c|c|}
\hline Location of Plant & To Honda Greenburg & to Anna Engine plant \\
\hline Borg Warner & 95 & 95.2 \\
\hline Dana & 205 & 139 \\
\hline Tower Automotive & 196 & 118 \\
\hline Lear Auto & 170 & 149 \\
\hline Visteon & 82.2 & 245 \\
\hline Fujitsu & 23.2 & 124 \\
\hline Intec & 164 & 260 \\
\hline AVERAGE DISTANCE & 133.6 & 161.4 \\
\hline
\end{tabular}

local supplier. In that case, these currently closed plants could supply products as follows:

\begin{tabular}{|c|c|c|c|c}
\hline & Table 10 & & \\
\hline Location of Plant & $\begin{array}{c}\text { To Honda } \\
\text { Greenburg }\end{array}$ & $\begin{array}{c}\text { to Anna Engine } \\
\text { plant }\end{array}$ & Min Dist & Where ? \\
\hline Borg Warner & 95 & 95.2 & 95 & $\mathrm{~A}$ \\
\hline Dana & 205 & 139 & 139 & $\mathrm{~A}$ \\
\hline Tower Automotive & 196 & 118 & 118 & $\mathrm{~A}$ \\
\hline Lear Auto & 170 & 149 & 149 & $\mathrm{~A}$ \\
\hline Visteon & 82.2 & 245 & 82.2 & $\mathrm{G}$ \\
\hline Fujitsu & 23.2 & 124 & 23.2 & $\mathrm{G}$ \\
\hline Intec & 164 & 260 & 164 & $\mathrm{D}$ \\
\hline $\begin{array}{c}\text { AVERAGE } \\
\text { DISTANCE }\end{array}$ & 133.6 & 161.4 & 110.06 & \\
\hline
\end{tabular}

Notice now that the targeting tier 2 business to replace closed plants (Borg Warner, Dana, Tower and Lear) keeps average travel distance to Anna, $\mathrm{OH}$ at 125 miles below current average for tier 2 of 134 miles. At the same time targeting tier 1 business to replace closed plants (Visteon, Fujitsu) keeps their average travel to Greensburg to 52.7 miles -below current average for tier 1 of 56.3 miles.

This analysis suggests a need to understand that before new product initiatives are targeted for reclaimed plants, targeting of business to leverage existing infrastructure may make them more competitive. 
3) Hoosier Automotive Focus: Key suppliers locate to create a Hoosier automotive corridor. The analysis of this focus remains the same as in phase 2 and will thus not be repeated.

Given these three possible areas of focus, how should INDOT choose a viable strategy going forward? Possible issues to consider in making this decision may include:

- INDOT budget constraints

- Maximizing support from LEDO's/EDC's

- Best potential overall strategy for Indiana's economic impact

- Maximize the number of towns with available skill set and access to delivery points

Developing a model to choose the specific projects that will attain the desired goal required data from INDOT that was not made available to this project team within the project time frame.

However,

- We have identified a set of projects primarily SR3 and SR 9, SR 46 and US 50.

- We leave open the questions regarding...

-How will "Major Moves" projects for these roads affect average speeds to Greensburg and to highways out of state?

-When will these projects generate desired traffic flow rates?

-What will it cost to execute desired projects?

- One must seriously consider if INDOT is willing and able to coordinate with the numerous IEDC's/business groups to develop a cohesive strategy.

\section{Conclusions}

A summary of the results of this study are as follows:

Possible strategic choices can be grouped under three different categories that were termed "Shared Supply Focus", "Hoosier Automotive Focus" and "Reclamation Focus".

(a) Speed counts - Reprioritizing existing projects can provide the difference between being viewed as an economic development leader, or a support service follower.

(b) It's not too late -INDOT has 12-24 months yet to plan and execute improvements that would benefit economic development.

(c) Evaluating projects strategically can have a significant impact on economic development outcomes in the future.

We believe that the results of this focused study suggest that a strategic approach to projects can enable INDOT to enhance its role as a contributor to industrial supply chain competitiveness in Indiana. 


\section{Recommendations}

The study suggests that for INDOT to benefit from this study to the maximum extent possible, they should consider developing the following as part of the ongoing implementation plan:

(a) For each of the three strategic directions, and associated current projects, understand their impact on supply chain flows. This will require utilizing known and approved project data to evaluate the cumulative project impact on flows, safety and other factors throughout the identified focus areas/regions. This can be accomplished through the use of existing INDOT models/tools without further cost of development.

Ideally, this would incorporate the number of Honda trips by truckload estimated between the various sites on the target roadways, with a traffic simulation being run to indicate the prospective congestion issues at hand and on the horizon.

It is further suggested that the current INDOT projects be incorporated in the simulation and have rail lines "overlaid" onto the maps to highlight the intersections of key interstates/roads and rail.

(b) For each of these strategic directions, monitor the decisions made by economic development authorities and potentially prioritize the projects in that region to maximize INDOT's impact on economic activity

(c) Improve coordination between county decisions, local INDOT and Central INDOT as well as LEDOs, IEDC and Honda supply chain participants so that potential new plants linked to the supply chain can be competitive.

(d) INDOT can play a proactive role in demonstrating how their project initiatives, by catering to flows generated by the supply chain can add to overall state competitiveness

\section{Expected Benefits/Deliverables/Implementation/Cost Savings}

The delivered benefits of this study to INDOT are:

(a) A description of potential auto component supply chain and possible flows.

(b) An identification of strategic INDOT project groupings that will maximize the impact specific economic development initiatives.

(c) A delivered detailed list of all suppliers, Honda, Toyota, LEDOs, IEDC discussions, maps of their locations and activity, that suggest their projections of future economic activity and INDOT's role in making it successful.

(d) Justification of sets of Major Moves projects that impact the Honda supply chain and thus make an even better case for the projects.

(e) The possibility of using the results of this study with INDOT models of project impact on speed, flow rates etc. to build a more detailed model of the Honda supply chain impact on traffic variables. 


\section{Bibliography/References}

1. Photo source: (C) Honda 2007 (c) Copyright 2006, Greensburg Decatur County Chamber of Commerce.

2. “COLLABORATE / COMPETE : RETHINKING INTER-FIRM RELATIONS

IN THE JAPANESE AUTOMOBILE INDUSTRY - A-traditional views: dualisms empirical and analytical” (Part 1)

“HONDA'S NORTH AMERICAN INVESTMENTS AND PARTS SOURCING PRACTICES (Part 2)

“ORGANIZATIONAL FRAMEWORKS” (Part 3)

“SPATIAL FRAMEWORK” (Part 4)

“INTER-FIRM PRACTICES WITHIN THE HONDA JIT REGION" (Part 5)

Material of: GERPISA, Université d'Evry-Val d'Essonne, Cedex, France

E-Mail:contact@gerpisa.univ-evry.fr www.univ-evry.fr

3. "Rail America to upgrade roadbed between Shelbyville and Cincinnati”, Indianapolis

Business Journal, IBJ Staff , http://www.indianaeconomicdigest.net, 6/25/2007 11:08:00

AM

4. Presentation package presented by Gary Mabry, Honda Manufacturing of Indiana, LLC, 2007 Indiana Logistics Summit, September 25-26, 2007.

5. Telephone interview conducted with graduate assistant and Mr. Kim Hill, Director, Automotive Communities Program Associate Director, Economics and Business Group, Center for Automotive Research December 2007, in conjunction with presentation materials presented by Mr. Kim Hill at the Greensburg Auto Expo, on November 28, 2007. His presentation was entitled, "Trends in the North American Automotive Industry Crisis or Opportunity”, in which he cites the following source: Contribution of the U.S. Motor Vehicle to the Economies of the United States, California, New York, and New Jersey, Center for Automotive Research, 2003; Contribution of Toyota to the Economies of Fourteen States and the United States in 2003, Center for Automotive Research 2005; Contribution of the Motor Vehicle Supplier Sector to the Economies of the United States and Its 50 States, Center for Automotive Research 2007. See appendix 6 for presentation materials.

6. Telephone interviews conducted with graduate assistant and INDOT/LEDO/EDC officials. See appendix 6 for interview notes.

7. "Major Moves" and "contract letting database" refer to activity department activity planned and underway by Indiana Department of Transportation. More information and frequently asked questions regarding both can be found at: http://www.in.gov/indot/2276.htm, and http://www.in.gov/indot/2270.htm . For the purpose of this project the most recent project listings were utilized at the time of October, 2007. See appendix 6 for referenced documents. 


\section{Appendices}

Appendix 1 - Accepted Proposal, Budget, Progress Schedule \& Reporting plan Appendix 2 - Study advisory committee

Appendix 3 - Principal Investigator Biography

Appendix 4 - Five chapters from GERPISA, Université d'Evry-Val d'Essonne, Cedex, France, entitled as follows:

1) COLLABORATE / COMPETE : RETHINKING INTER-FIRM RELATIONS IN THE JAPANESE AUTOMOBILE INDUSTRY - A-traditional views: dualisms empirical and analytical (Part 1)

2) HONDA'S NORTH AMERICAN INVESTMENTS AND PARTS SOURCING PRACTICES (Part 2)

3) ORGANIZATIONAL FRAMEWORKS (Part 3)

4) SPATIAL FRAMEWORK (Part 4)

5) INTER-FIRM PRACTICES WITHIN THE HONDA JIT REGION (Part 5)

Appendix 5 - Related news articles and website reference articles.

Appendix 6 - Complete data repository to be provided with final report via CD due to amount of accumulated information. 
Appendix 1

Accepted Proposal, Budget, Progress Schedule \& Reporting plan 
INDIANA DEPARTMENT OF TRANSPORTATION

100 North Senate Avenue

Room N755

Indianapolis, Indiana 46204-2249

(317) 232-5533

Fax (317) 232-0238
REPLY TO:

INDO'T Office of Research and Development

P.O. Box 2279

West Lafayette. Indiana 47906

(765) $463-1521$

June 1, 2007

Dr. Kumares C. Sinha, Director

Joint Transportation Research Program

School of Civil Engineering

Purdue University

West Lafayette, IN 47907

Subject: Approval of SP\&R Part II Research Proposal "Understanding the Impact of INDOT Projects on Automotive Industry Cluster Logistics Costs: A Case Study of the Honda Plant," SPR-3216

Dear Professor Sinha:

The subject study is approved as recommended by the JTRP Board at its June 28, 2007 meeting. The study is to be funded through the FY 2008 SP\&R Part II Work Program. The study is scheduled for a 19 -month period, which includes 4 months for review and revision of the final report. The total budget is $\$ 112,821.00$ with the starting date of June $1,2007$.

Please ensure that all project personnel have signed and forwarded the liability waiver before commencing the project. Personnel should also receive the required safety training.

Barry Partridge, Tom Harris, John Jordan, Jeff Logman, Steve Smith, Eryn HaysFletcher, Bart Mueller, Bernie Seel, John Weaver, and Keith Bucklew of INDOT, Kumares Sinha of Purdue and Jay DuMontelle of FHWA will be on the Study Advisory Committee (SAC) for this study. Barry Partridge will be the Project Advisor.

By copy of this letter, we would like to inform the Principal Investigator and the SAC members of the SAC's responsibilities as specified in the JTRP User's Manual for Research and Implementation (page 11).

- Ensure the research meets the needs of INDOT' and other designated users and fulfills the objectives of the established research need.

- Assist in identifying PIM and other research users from the INDOT business units.

- Assist Pl in preparation of the research proposal and provide initial approval.

- Provide technical guidance to PI during conduct of research.

- Attend SAC meetings.

- Review changes to the project scope and/or work plan proposed by the PI.

- Review and provide comments for draft final reports 
- Provide initial approval of interim and final research reports.

- Recommend to the PI methods and personnel for implementing the research.

- Attend project close-out meeting.

The JTRP User's Manual for Research and Implementation outlines the policies and procedures for the JTRP including the SAC's general roles and responsibilities. The User's Manual is available online at the JTRP website by following this link: hitg://rebar.ecn.purdue.edu//TRP/ProgAdmin/manual.pdf.

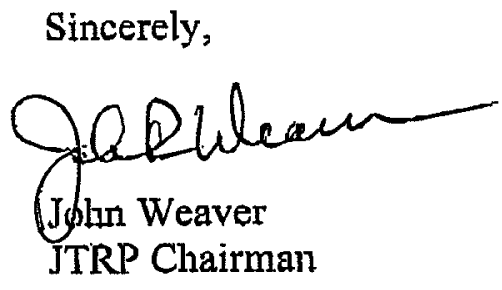

ProposalApproval3216.pdf

Attachment

cc: Mary Phillips, Research and Development

Scott Newbolds, Research and Development

Barry Partridge, Research and Development (with a copy of proposal)

John Weaver, Business and Asset Management (with a copy of proposal)

Tom Harris, Division of Construction Management (with a copy of proposal)

John Jordan, Division of Local Programs (with a copy of proposal)

Jeff Logman, Seymour District (with a copy of proposal)

Steve Smith, Office of Urban \& Corridor Planning (with a copy of proposal)

Eryn Hays-Fletcher, Office of Urban \& Corridor Plan. (with a copy of proposal)

Bart Mueller, Vincennes District (with a copy of proposal)

Bernie Seel, Deputy Commissioner (with a copy of proposal)

Keith Bucklew, Office of Program Management (with a copy of proposal)

Kumares Sinha, Purdue University (with copy of proposal)

Jay DuMontelle, FHWA (with a copy of proposal) 


\section{PURDUE}

\begin{tabular}{llllllllll}
\hline & $\mathbf{N}$ & I & V & E & R & S & I & T & $\mathbf{Y}$
\end{tabular}

JOINT TRANSPORTATION RESEARCH PROGRAM

July 5, 2007

Mr. John Weaver

Chief Engineer

INDOT Executive Offices

100 North Senate Avenue

Indianapolis, Indiana 46204

Attn: Mr. Barry K. Partridge

Chief, Division of Research

Re: FY2008 Research Proposal

Dear Mr. Weaver:

Please find enclosed the following FY 2008 research proposal that was presented and approved at the June 28, 2007 JTRP board meeting.

Title: $\quad$ Understanding the Impact of INDOT Projects on

Automotive Industry Cluster Logistics Costs: A Case

SPR No.

Study of the Honda Plant

Prin. Investigator(s): Ananth lyer

Starting Date:

Ending Date:

Study Period:

$6 / 1 / 07$

$11 / 30 / 08$

19 months

Total Cost:

$\$ 112,821.00$

JTRP File No:

9-10-92

We look forward to hearing from you to confirm that we can proceed with this project. If you have any questions, please contact Karen Hatke or me at your convenience.

Sincerely yours,

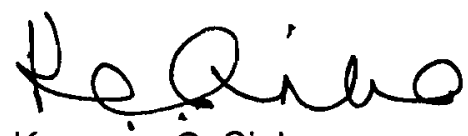

Kumarès C. Sinha

Director

KCS:kh

Enc.

cC: K. Pelfree

Indiana Department of Transportation and Purdue University 
Proposal for Part II Research Study

Understanding the Impact of INDOT Projects on Automotive Industry Cluster Logistics

Costs: A Case Study of the Honda Plant

\author{
Principal Investigator (PI) \\ Ananth Iyer \\ Professor \\ Krannert School of Management \\ Purdue University \\ West Lafayette, IN 47907 \\ aiyer@mgmt.purdue.edu \\ 765-494-45144
}

Joint Transportation Research Program

Project No. C-36-6700OO

File No. 9-10-92

SPR-3216

Prepared in Cooperation with the Indiana Department of Transportation and the

U.S. Department of Transportation

Federal Highway Administration

The contents of this report reflect the views of the author who is responsible for the facts and the accuracy of the data presented herein. The contents do not necessarily reflect the official views or policies of the Indiana Department of Transportation or the Federal Highway Administration at the time of publication. This report does not constitute a standard, specification, or regulation.

\author{
Purdue University \\ West Lafayette, Indiana 47907
}

June 15, 2007 
Project Administrator: Barry Partridge

Study Advisory Committee Members:

Bernie Seel, Deputy Commissioner, bseel@indot.in.gov

Keith Bucklew, Office of Program Management, kbucklew@indot.in.gov

Tom Harris, Division of Construction Management, tharris@indot.in.gov

John Jordan, Local Programs Division, jjordan@indot.in.gov

Jeff Logman, Seymour District, jlogman@indot.in.gov

Steve Smith, Office of Urban \& Corridor Planning, ssmith@indot.in.gov

Eryn Hays-Fletcher, Office of Urban \& Corridor Planning, ehays@indot.in.gov

Bart Mueller, Vincennes District, bmueller@indot.in.gov

Jay DuMontelle, FHWA, (317) 226-7491, Jay.DuMontelle@fhwa.dot.gov 


\section{Introduction}

It is unclear how the supply chain tier of Honda suppliers will evolve over time, what locations will be chosen by primary and secondary tier suppliers, how local plants (within a broadcast distance) will be used vs. warehouse inventory etc. Currently, plans for plants are being announced which consider current and future planned infrastructure changes and mode changes. In addition, the Honda plant opening is occurring as auto suppliers such as Delphi and Visteon and OEMs shut down plants and warehouses across the state.

\section{Background information}

1. Honda, like many modern auto companies, manufactures a small (less than $15-20 \%$ ) of the value added in an automobile. Thus suppliers play a large role in the manufacture of the product.

2. Honda relies on lean manufacturing and low inventories, thus suppliers are expected to make multiple deliveries (daily or weekly)

3. Since the production sequence is tied to dealer orders, and production is expected to be mixed line, the exact sequencing of deliveries to match the production sequence is crucial. Thus data is expected to be broadcast potentially several times a day for exact sequenced delivery of parts.

4. Since some of the parts will be imported, while others made locally, there is a need to consider the linkages to ports and thus flows from outside the state.

5. Honda is known to focus on balancing its flows so as to have a stable transport system to feed its production.

6. The outbound shipments of finished cars will use a combination of rail and truck.

7. The supply chain flows will thus require consideration of imported components, local production and deliveries and outbound shipments to dealers across different modes.

8. Responsibility of these modes may vary across entities across the state, so coordination of projects across these entities is crucial.

\section{Problem Statement}

Identify approaches for INDOT to be an active partner in facilitating supply chain effectiveness and thus maximize the economic impact of INDOT projects on the Automotive Cluster in Southern Indiana

\section{Objective}

This project proposes to develop primary data through interactions with area economic development personnel, Manufacturing Extension personnel, Honda sources, INDOT personnel and potential supplier executives to maximize INDOT facilitated economic impact maximization.

\section{Work Plan}

In order to understand the impact, we will work with potential counties such as Decatur county, supplier locations in Shelbyville, Connersville, Newcastle, adjustments to the Central Indiana railroad, interchanges in Greensburg etc. We will thus focus on all potential towns and associated counties within a reasonable distance from Greensburg as potential data 
sources. In addition, all published sources of data and potential data from other OEM plants in Indiana will be collected and analyzed.

\section{Scope of the Work Plan will include:}

1. Use of database sources such as IMA, Census data etc, analyze existing companies in the area in the auto components industry.

2. Use of the resources from TAP and MEP, as well as area Economic Development officials, identify common issues that affect auto components manufacturers in the area.

3. Use direct connections with Honda personnel to understand potential transportation and logistics bottlenecks.

4. Use INDOT personnel as well as personnel from the Ports of Indiana, Airports, truck and other transport companies to identify potential planned projects and impacts in the region. In these discussions, explore how past planning to accommodate auto plant openings around the state were accomplished.

5. Develop a survey to systematically understand the flows across the supply chain. This survey will be documented using Surveymonkey but will require active data collection and follow up to generate information.

6. Analysis of the survey will be used to check findings.

7. Finally, the results will be disseminated to survey participants and INDOT personnel to understand the impact of projects on enhancing potential supply chain performance.

\section{Benefits}

Primary data collected from discussions with Honda and suppliers, as well as survey data will provide a background for a description of planned industry development to support Honda's manufacturing targets. Discussions and data collection from local county officials will describe their efforts to attract suppliers and provide access to Greensburg for timely logistics. This data will thus permit projection of the economic impact for each of INDOT's planned projects in the region. The key benefit of this project will be to enhance INDOT's ability to project economic benefits associated with project choice and timing in the region around Greenburg. The developed approach can be a prototype for other such studies around the state.

\section{Deliverables/timeline}

\section{(Assuming a start date of JUNE 1)}

1. Database analysis and initial contacts (4 months)

2. Onsite meeting, initial discussions and survey development (6 months)

3. Initial report (3 months)

4. Detailed visits to supplier locations and supply chain mapping (4 months)

5. Interim report and summary meeting (6 months)

6. Contacts with INDOT, Rail, Ports etc and information gathering (3 months)

7. Second contact and discussions with Honda and suppliers and feedback (3 months)

8. Final Reports including draft report and required updates/meetings (4 months) 


\section{Specific reports that will be completed:}

(a) A map of the Honda auto supply chain with current and potential planned supplier locations

(b) A specific listing of all projects in the region, their completion dates and potential impacts on logistics costs. This analysis will consider the potential impact of possible mode choice on logistics costs

(c) A summary of data gathered from surveys which identifies the potential impact of INDOT projects by suppliers, area economic development representatives, Honda personnel, transport mode representatives etc.

(d) An overall summary report that can be used to understand how the Honda plant supply chain impact was managed and thus prototype report for future assessments.

\section{Resources}

The PI, Professor Iyer, will commit $10 \%$ of his time, each year, across two academic years to guide the project. Data collection will be accomplished through use of graduate and undergraduate students at Krannert. Overall coordination will be provided by Mary Pilotte, Managing Director of DCMME/GSCMI.

\section{Project Progress Schedule (06 /01/07 - 11/30/08)}

\begin{tabular}{|c|c|c|c|c|c|c|c|c|c|c|c|c|c|c|c|c|c|c|c|}
\hline \multirow{2}{*}{ Task } & \multicolumn{11}{|c|}{2007} & \multicolumn{7}{|c|}{2008} & Actual \% \\
\hline & $\mathbf{J}$ & $\mathbf{J}$ & A & C & & D & $\mathbf{J}$ & $\mathbf{F}$ & $\mathbf{M}$ & $A$ & $\mathbf{M}$ & $\mathbf{J}$ & $\mathbf{J}$ & A] & $\mathbf{s}$ & 0 & $\mathbf{N}$ & D & Completion \\
\hline 1. Database analysis and initial & & & & & & & & & & & & & & & & & & & 0 \\
\hline 2. Onsite meeting, initial & & & & & & & & & & & & & & & & & & & \\
\hline $\begin{array}{l}\text { discussions and survey } \\
\text { development }\end{array}$ & & & & & & & & & & & & & & & & & & & 0 \\
\hline 3. Initial report (no meeting) & & & & & & & & & & & & & & & & & & & 0 \\
\hline & & & & & & & & & & & & & & & & & & & \\
\hline 4. Visits to supplier locations and & & & & & & & & & & & & & & & & & & & \\
\hline supply chain mapping & & & & & & & & & & & & & & & & & & & 0 \\
\hline 5. Interim Report \& meeting & & & & & & & & & & & & & & & & & & & 0 \\
\hline & & & & & & & & & & & & & & & & & & & 0 \\
\hline 6. Contacts with INDOT, Rail, & & & & & & & & & & & & & & & & & & & \\
\hline $\begin{array}{l}\text { Ports etc and information } \\
\text { gathering }\end{array}$ & & & & & & & & & & & & & & & & & & & 0 \\
\hline 7. $2^{\text {nd }}$ contact and discussions with & & & & & & & & & & & & & & & & & & & \\
\hline $\begin{array}{l}\text { Honda and suppliers and } \\
\text { feedback }\end{array}$ & & & & & & & & & & & & & & & & & & & 0 \\
\hline 8. Final Reports including draft & & & & & & & & & & & & & & & & & & & \\
\hline $\begin{array}{l}\text { report and required } \\
\text { updates/meetings }\end{array}$ & & & & & & & & & & & & & & & & & & & 0 \\
\hline
\end{tabular}




\section{Budget}

(For 18 months - beginning JUNE 1, 2007)

\begin{tabular}{|c|r|}
\hline \hline \multicolumn{1}{|c|}{ ITEMS } & $\begin{array}{r}\text { PROJECT } \\
\text { BUDGET }\end{array}$ \\
\hline Salaries \& wages (incl. GA fee remis.) & $\$ 110,711.00$ \\
\hline Supplies \& Services & 610.00 \\
\hline Travel & $1,500.00$ \\
\hline TOTAL & $\$ 112,821.00$ \\
\hline
\end{tabular}

Consisting of:

- Graduate Student (18mo)

- Faculty cost: $18 m o-E a c h$ year 1 month summer at $10 \%$

- Staff support cost: $\$ 18,717$

- Travel: $\$ 1,500$

- Supplies: $\$ 610$

\section{Reporting Plan}

Estimated completion dates:

Interim Report - December 2007

Draft final Report - August 2008

Final Report - November 2008 


\section{RATING}

\section{COMMENTS}

CONCEPT OF PROBLEM:

4 I agree with the concept of the problem; advanced identification of problems/opportunities to improve INDOT's responsiveness to automotive industry development issues. The only suggestion I would include to the identified problem is that the Automotive Cluster impact requiring INDOT attention may extend beyond Southeast Indiana. It is important for INDOT to understand and anticipate their participation in supporting the supply chain surrounding the new Honda plant. However, in addition to the Honda development in Southeast Indiana, INDOT already supports supply chain effectiveness around the other corners of the state: Toyota (Southwest), Subaru/Toyota (Northwest), and GM Truck (Northeast). How active has INDOT been historically towards supporting these supply chains? How can INDOT continuously improve their role as active partner based on their previous actions with incoming automotive assembly plants? How will adding Honda constrain the supply chains used by the existing automotive assembly plants?

Although the analysis of this problem may be limited specifically to providing assistance benefitting the new Honda developments, I would expand the impact scope beyond Southern Indiana's Automotive Cluster to consider the entire state's impact.

RESEARCH APPROACH:
4 I agree that identification and outreach to Honda suppliers and supply chain participants is key towards INDOT maximizing its support. A thorough mapping of the developing supply chain through qualitative interviews of key participants will be vital fpr INDOT in proactively identifying the potential scope and timing of infrastructure bottlenecks and congestion issues.

\section{APPLICATION OF RESULTS AND
ANTICIPATED BENEFITS: \\ APPLICATION OF RESULTS AND
ANTICIPATED BENEFITS:}

PRINCIPAL INVESTIGATOR(S):
4 With the amount of INDOT investment in infrastructure development, I agree with the benefits of this research resulting in more effective planning of projects to support Honda's targets. The ability to better justify INDOT's projects, with earlier identification of their benefits will also aid INDOT's proactive partnering in support of the supply chain activities.
4 I've seen and approve the quality of work previously published by Dr. lyer. I believe his analysis strikes a very effective balance between qualitative and quantitative research towards actionable results.

AVERAGE RATING: $\quad 4$

SUGGESTIONS FOR IMPROVEMENT: The improvement I see most needed to this research is an expanded analysis on the transporation modes that will support the supply chain activities, and act as principal users of the INDOT infrastructure developments. In addition to INDOT, Rail, and Pots information gathering, I would make sure that key participants in Indiana's trucking and air freight industry are included as these are critical suppliers of time-critical shipments to the automotive assembly industry. With growing issues of 
congestion and rising fuel costs, how well are these modes supported within the state to meet the supply chain needs of the Automotive Cluster. 
CONCEPT OF PROBLEM: 3

RESEARCH APPROACH: 3 The work plan involves mostly surveys, interviews, and other vaguely specified forms of data collection. While the proposal is not very specific, the work seems doable.

\begin{abstract}
APPLICATION OF RESULTS AND ANTICIPATED BENEFITS:
\end{abstract}

1 The proposal is very vague regarding the anticipated results that will or may follow from the proposed work, and how that may benefit any part of the economy in Indiana. The proposal has no discussion or example of potential results of the research and how the results may be useful.
PRINCIPAL INVESTIGATOR(S):

3

The PI has done some interesting research in the past, and is knowledgeable. The proposal does not clearly state the level of effort that the PI will be committing.

\section{AVERAGE RATING: $\quad 2.5$}

SUGGESTIONS FOR IMPROVEMENT: The proposal is very vague regarding the potential results. Much more clarity and specificity is needed. 


\section{RATING}

\section{COMMENTS}

CONCEPT OF PROBLEM: 4 Adequate coverage of problem.

RESEARCH APPROACH: 4 Parallel approach for data collection is good. Survey approach, participants could be explained a little better. Assumption is that survey will be conducted in a user friendly manner - face to face rather than mailing.

APPLICATION OF RESULTS AND ANTICIPATED BENEFITS:
3 Restatement of problem is good but it could be more clear what the useful deliverables will be.

PRINCIPAL INVESTIGATOR(S): 4 Principal investigator's credentials are noteworthy.

AVERAGE RATING: $\quad 3.75$

SUGGESTIONS FOR IMPROVEMENT: On pages $3 \& 4$, tasks do not appear to be aligned with schedule. Likewise, budget reconciliation could be clearer. 


\section{Proposal enhancements based on external review feedback Inclusions, eliminations, omissions:}

Reference Ext. Reviewer \#2: Application of results \& anticipated benefits Rating - 1 "The proposal is very vague regarding the anticipated results that may follow”, "...how that might benefit any part of the economy in Indiana”

Response - Deliverables and timelines item (d):

a. The addition of this element will demand additional questions be asked in the survey regarding what processes are used currently, from that data and determined outcomes, best practices can be developed which would allow the study to be replicated across regions or industries for a broader statewide impact in the future. These practices when shared could better prepare other counties/regions for economic engagement of this nature.

b. Entering into the study with a blank slate in terms of expected outcomes, we believe, will allow for the most dynamic and interesting report of findings with the least amount of pre-analysis influence injected.

\section{Reference Ext. Reviewer \#2: Principal investigator Rating -3}

"The proposal does not clearly state the level of effort that the PI will be committing."

Response - Resources:

a. The addition of details regarding Dr. Iyer's time allocated to the project are now included for review.

\section{Reference Ext. Reviewer \#3: Other suggestions}

“..tasks do not seem to be aligned with schedule."

Response - Project Progress Schedule:

a. Some text which outlined planned project progress, seemed to conflict with elements of overall project Gantt chart. Revisions were made to master Gantt chart to clearly match project milestone text, without altering overall project schedule. 


\section{Appendix 2 \\ Study Advisory Committee List}

\section{SAC Members SPR-3216}

Keith Bucklew

INDOT Office of Freight Mobility

100 North Senate Avenue

Indianapolis IN 46204

Phone: $317 / 232-2376$

Fax: $\quad 317 / 233-4929$

E-mail: kbucklew@indot.in.gov

Jay DuMontelle

FHWA Indiana Division

575 North Pennsylvania, Room 254

Indianapolis IN 46204

Phone: $317 / 226-7482$

Fax: $\quad 317 / 226-7482$

E-mail: jay.dumontelle@fhwa.dot.gov

\section{Tom Harris}

INDOT Office of Construction Technical Support

100 North Senate Avenue

Indianapolis IN 46204

Phone: $317 / 232-4910$

Fax: 317/233-5314

E-mail: tharris@indot.in.gov

\section{Eryn Hays-Fletcher}

INDOT Office of Urban \& Corridor Planning

100 North Senate Avenue

Indianapolis IN 46204

Phone: 317/232-5458

Fax:

E-mail: ehays@indot.in.gov

John Jordan

INDOT Local Programs Office

100 North Senate Avenue

Indianapolis IN 46204

Phone: 317/232-0682

Fax: $\quad 317 / 233-4929$

E-mail: jjordan@indot.in.gov
Jeff Logman

INDOT Seymour District

P.O. Box 550

Seymour IN 47274

Phone: $812 / 524-3739$

Fax: $\quad 812 / 522-7658$

E-mail: jlogman@indot.in.gov

\section{Bart Mueller}

INDOT Vincennes District-Bloomfield Unit

3650 S. Highway 41

Vincennes IN 47591

Phone: 812/895-7394

Fax: $\quad 812 / 882-2752$

E-mail: bmueller@indot.in.gov

Barry Partridge (PA)

INDOT Office of Research and Development

P.O. Box 2279

West Lafayette IN 47906

Phone: 765/463-1521

Fax: $\quad 765 / 497-1665$

E-mail: bpartridge@indot.in.gov

\section{Bernard Seel}

INDOT

100 North Senate Avenue

Indianapolis IN 46204

Phone: $317 / 232-1472$

Fax: $\quad 317 / / 232-0238$

E-mail: bseel@indot.in.gov

\section{Kumares Sinha}

Purdue University School of Civil Engineering 550 Stadium Mall Drive

West Lafayette IN 47907

Phone: 765/494-2211

Fax: $\quad$ 765/496-7996

E-mail: sinha@ecn.purdue.edu 
Steve Smith

INDOT Office of Urban \& Corridor Planning

100 North Senate Avenue

Indianapolis IN 46204

Phone: $317 / 232-5646$

Fax: $\quad 317 / 233-0958$

E-mail: ssmith@indot.in.gov

John Weaver

INDOT

100 North Senate Avenue

Indianapolis IN 46204

Phone: $317 / 233-1524$

Fax: $\quad 317 / 232-5478$

E-mail: jweaver@indot.in.gov 


\title{
Appendix 3 \\ Researcher Biography
}

\author{
Principal Investigator: Ananth Iyer \\ - Susan Bulkeley Butler Chair in \\ Operations Management and Director, \\ DCMME and GSCMI \\ - Ph.D., Industrial and Systems \\ Engineering, Georgia Institute of \\ Technology, 1987 \\ - $\quad$ M.S., Industrial Engineering and \\ Operations Research, Syracuse \\ University, 1983 \\ - B. Tech., Mechanical Engineering, India \\ Institute of Technology (Bombay), 1982
}

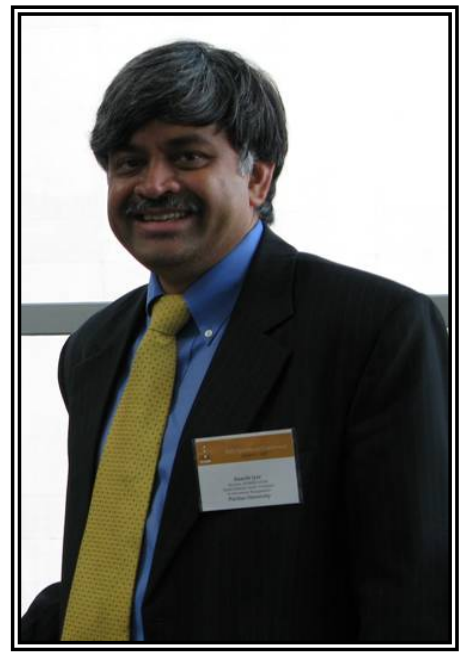

Professor Iyer was named Purdue University Faculty Scholar in 1999. His teaching and research interests are operations management and logistics. Professor Iyer's research currently focuses on analysis of the impact of promotions on logistics systems, and analysis of the impact of competitors on operational management models. His other topics of study include inventory management, effect of supplier contracts, and use of data sets in operations management model building. His published works include "The Supply Chain Impact of Smart Customers in a Promotional Environment" with Huchzermeier and Freiheit, M\&SOM, 2002; "Inventory Cost Impact of Managing Lead Times using Priority Queues based on Demand Uncertainty," Naval Research Logistics, 2002; "A Logistics Model in a Promotion Sensitive Grocery Environment" with J. Ye, Networks, 2001; “Assessing the Value of Information Sharing in a Promotional Environment" with J. Ye, Manufacturing \& Service Operations Management, 2000; “Quick Response in Manufacturer Retailer Channels" with Mark Bergen, Management Science, 1997; "Backup Agreements in Fashion Buying - The Value of Upstream Flexibility" with G. Eppen, Management Science, 1997; and "Separating Logistics Flows in the Chicago School System" with D. Elsenstein, Operations Research, Vol. 44, No. 2, 1996.

He was the FMC Scholar in 1990-91. He is on the editorial boards of IIE Transactions, the ECR Journal and Manufacturing \& Service Operations Management editorial board, and member of INFORMS. He was president-elect of the MSOM Society of INFORMS in 2001-02 and served as president for the year 2002-03. Prior to joining the Krannert faculty in 1996, Professor Iyer taught at the University of Chicago. 
He has been affiliated with the Production and Distribution Research Center at Georgia Tech, and a consultant to Daymon Associates, Sara Lee, Turner Broadcasting and others. He served his Chicago community as a pro bono consultant to the Chicago School System and the Chicago Streets and Sanitation Department.

PI Iyer also participated in and completed the following recent INDOT sponsored projects:

1. Project Identification: Indiana SPR-3050

656-1310-0364

File No. 3-1-17

Project Title: INDOT Customer Service

Principal Investigator(s): Ananth Iyer and Michael Hoeck

Date Started: July 1, 2005

Completion Date: June 30, 2006

Research Agency: Joint Transportation Research Program, Purdue University

2. Project Identification: Indiana SPR-3049

656-1310-0374

File No. 3-4-30

Project Title: INDOT Furniture Supply Chain

Principal Investigator(s): Ananth Iyer and Svenja Sommer

Date Started: July 1, 2005

Completion Date: June 30, 2006

Research Agency: Joint Transportation Research Program, Purdue University 


\section{Appendix 4}

Five chapters from GERPISA, Université d'Evry-Val d'Essonne, Cedex,

France, entitled as follows:

1. COLLABORATE / COMPETE : RETHINKING INTER-FIRM RELATIONS IN THE JAPANESE AUTOMOBILE INDUSTRY - A-traditional views: dualisms empirical and analytical (Part 1)

2. HONDA'S NORTH AMERICAN INVESTMENTS AND PARTS SOURCING PRACTICES (Part 2)

3. ORGANIZATIONAL FRAMEWORKS (Part 3)

4. SPATIAL FRAMEWORK (Part 4)

5. INTER-FIRM PRACTICES WITHIN THE HONDA JIT REGION (Part 5) 


\section{PART I : COLLABORATE / COMPETE : RETHINKING INTER-FIRM RELATIONS IN THE JAPANESE AUTOMOBILE INDUSTRY}

\section{A/ Traditional views : dualisms empirical and analytical :}

Until the 1980s the prevalent Western analysis of assembler-supplier relations in the Japanese automobile industry protrayed a dualistic structure; on the one hand a few large and powerful assembly firms situated at the head of supplier chains, on the other hand myriad small and weak components and materials manufacturers feeding parts to each other and finally to assemblers. The latter held the reins of control over the suppliers, perhaps through partial ownership, or because the latter were sometimes spinoffs from the former, or because a widespread system of single sourcing of parts and of long-term relationships effectively closed alternative markets for those suppliers was normal practice, particularly during periods of market weakness when reduced costs could be forced down into the supplier chain. Moreover the situations of employees at assemblers and suppliers reflected the positions of their employers; at assembly firms, life-time employment and relatively high wages were defended by enterprise unions (even while employees worked very long hours and took few holidays), at suppliers, part-time work or family firm sweatshop exploitation were rife. This dualistic exploitation structure is reflected in the widespread use of the word "subcontractor" - implying a very uneven relationship - - to describe Japanese supplier firms.

If this portrayal of a dualistic exploitation structure was by and large accurate during the 1950s and 1960s, during the 1980s it began to disappear from view as analysts abroad searched for the secrets of japanese success now more to emulate than to criticize. A revisionist interpretation developed, in which Western analysts - - aided by Japanese counterparts now finding a willing western audience - - argued that the dualist exploitation model no longer characterized the main thrust of innovative developments in the Japanese automobile industry. Indeed revisionism has spawned a new orthodoxy which overturns the old explanations. Thus, as far as workers were concerned, while it had been argued that assembly firms exploited docile workers in order to hold down costs, the new orthodoxy emphasized how the Japanese automobile industry in general had deployed flexible technologies, new modes of work organization, and had 
encouraged workers to actively participate in improvements to production processes. And success for Japanese products was due no longer to low-cost imitations of Western products, but to large investments in research and development that resulted in innovative products.

Mirroring firm-worker relations, the new themes in analyses of relations between assembly and supplier firms have become :

- collaboration rather than exploitation

- the crucial role of supplier firms in product development.

Dynamism in the production structure as a whole is no longer attributed to a relentless pursuit of lower costs but rather to a systemic and collaborative tendency to innovate new products and processes by supplier firms as well as assembly firms.

After the new orthodoxy made its appearance, the lessons that many western automobile manufacturers sought to learn from Japan regarding assembler-supplier relations comprised a rejection of their own typical relationships - - based on organizational distance, relentless price-cutting, dual sourcing, superficial relationships - in favour of a more integrated and systemic view of the overall production structure in which the full potential role of supplier firms to innovate products and processes could be realized.

However, in this analytically dualist shift from the old orthodoxy to its opposite, the new orthodoxy, we run the danger that the truth lies in between, that typical assembler-supplier relations in the Japanese automobile industry have in fact only moved along a continuum towards the revisionist interpretation, and even so only in certain respects. Recent empirical analyses point to the continued reproduction of a sector of small firms that are true subcontractors; ie they simply receive instructions on what to produce, and often receive their materials too, from another firm, and seem to possess little innovatory capacity. Indeed most innovation along the lines suggested by the new orthodoxy seems to have been focused upon first-tier (ie direct to assemblers) supplier firms, with these evolving to become designers and assemblers of modular components (ie complete assembled components) in their own right.

If we are to avoid the pitfalls of exaggeration and one-sided interpretations that characterize analytical dualism (note this approach also characterizes many studies comparing Japanese and North American automobile industries), we need to construct an alternative model of Japanese automobile industry assembler-supplier relations. Here we will propose, as a more balanced characterization, a tight organizational structure designed to ensure maximum benefits from both collaboration and competition 
among firms. In this model, that we will call for convenience the "CC model", both the old and the new orthodoxies retain their truths. The innovatory capacities described in the new orthodoxy are transposed to the collaboration element of the CC model, while the competition element captures the stresses and strains pictured in the old orthodoxy. The result is a more complex but more dynamic model than each orthodoxy alone could provide.

\section{B/ The CC model : organizational aspects}

Several organizational features - described in the CC model - define a fine and sharp double blade of collaboration and competition which provides a twin dynamic to the system, thus enabling daily assembler-supplier relationships to function most efficiently.

\section{Collaboration :}

1. Long-term relations : The reproduction of relations between particular firms over long periods enables not only development of the high degree of trust between firms but just as importantly promotes development of the specific forms of knowledge that allow inter-firm relations (and hence the division of labour) to be deepened and made more complex while still functionning efficiently as a whole. Thus individual people can understand the capacities and constraints of their opposite numbers in other firms, the overall capabilities od the partner firms are reciprocally understood, and the implications of particular idiosyncracies are factored in advance. This helps greatly to diffuse innovations - new products and processes - smoothly. Another result is that each firm knows how it should best react immediately when difficulties arise elsewhere in the system, without having to consult its partners.

2. Limited numbers of direct relationships : Maintenance by each firm of relations with only a limited number of other firms enables externally-oriented firm resources to be highly concentrated on understanding and dealing with each partner. Moreover relations with other firms can be understood and acted upon by a single person or by a small team - rather than by whole (eg purchasing) departments - who / which are then in a position both to react more rapidly to difficulties when necessary and to reflect more deeply upon improvements to the firm's external relations.

3. Formal ties : The more formal tying of firms to each other takes forms such as cross-equity holdings or various kinds of business associations such as keiretsu, the "family" structures of conglomerates. Some automobile firms have spun off supplier 
units to become institutionally separate firms with their own management, but remaining closely tied to their "parent". Kyoryokukai are associations that group suppliers of particular assemblers, and many suppliers belong to several of these simultaneously. The kyoryokukai function actively to channel information on new schemes (eg for product quality improvement) that assemblers want to disseminate down their supply chain. Membership of such an association also formalizes an intention to maintain a long-term relationship. All Japanese automobile producers except Honda are linked to a keiretsu and / or maintain kyoryokukai.

4. Exchange of personel : Towards the end of their career, engineers and managers at assembly firms may be retired and decanted to supplier firms of their career paths become blocked or if others are selected for higher positions. When they leave, they take with them intimate knowledge of the firm they have left, not only of its functionning but of personal contacts built up over the years. Firms also station their own personnel at partners' factories temporarily or semi-permanently, for all sorts of reasons ranging from joint research and development to aid in adopting new technologies to smooth introduction of new models.

5. Multiple tiering and vertical disintegration : That each firm maintains a relatively small number of direct relationships to other firms does not imply a small number of firms in the production structure as a whole, because each supplier firm occupies a niche in a multi-tiered pyramidal structure with an assembler at the apex, and incorporating and often very complex division of labour. There may be up to ten tiers of supplier firms, each undertaking specific tasks of materials production or subassembly. Over 10,000 supplier firms may directly and indirectly supply a single assembler. Only 500 of these are first-tier (direct) suppliers, and much recent product and process innovation in Japan appears to have been concentrated at this level. Firms become smaller in size further down the supplier chain, but the layers are said to remain clearly delineated.

This systematic tendency towards a vertical disintegration of production into long supplier chains implies a high degree of "outsourcing" of components and therefore a low level of value-added - around 30 percent - by the final assembler, which in part explains why Japanese assembly firms are able to make so many cars with so few employees of their own. According to the old dualistic orthodoxy, moving production of particular components and production processes back and forth between firms and subcontractors was explained in terms of a lack of capital at many supplier firms. But while this may have been the correct explanation many years ago, such continuing restructuring of the division of labour continues today, providing a high degree of 
flexibility for the system as a whole to incorporate quite rapid shifts in quantitative and qualitative demands from higher up the supplier chain.

Indeed it is in part the existence of multiple tiers within pyramidal production structures that explains the crucial role of - and hence the importance of analysing - interfirm relations in the Japanese automobile industry. For while each firm may have maintain relations with few other firms, systemic disintegration means that each assembler's production structure taken as a whole involves myriad such relations. And since high levels of outsourcing from assembly firms means that 70 percent of the value added in each automobile is due to firms in the supplier chain, the activities of Japanese supplier firms become even more central to industry strategies for increasing product quality, decreasing costs and increasing general innovatory capacity.

\section{Competition :}

1. Competition between assemblers : Japan's domestic market for finished automobiles is fiercely competitive, with nine assembly firms supplying final markets. Some of these firms are relatively new entrants; neither Honda, Suzuki nor Daihatsu manufactured automobiles thirty years ago. While some of the smaller firms are dependent upon their links to larger firms (eg Toyota-Daihatsu), powerful competitive tendencies remain which filter into the supplier chain as each assembler seeks to marshall its overall production structure into the competition with the structures of its rivals.

2. The outside threat to long-term relations : Long-term relations are maintained not for their own sake but because they continue to produce required results. Strict conditions can be set by the purchasing firm, in terms of annual price reductions or of improvements to product quality, with the implicit threat that there are alternative suppliers waiting in the wings to be awarded future contracts. Loss of a major contract may be fatal to a supplier firm given that other potential customers are likely to be hooked into long-term relations with satisfactory suppliers. And knowledge that a contract was not renewed by one purchaser customers. Thus even if non-renewal of contract in fact happens infrequently the penalty - and hence the threat - is still very severe.

3. Dual sourcing Japanese-style : Commentators comparing Western with Japanese firms have drawn attention to patterns of what they call "single sourcing" - ie each part is bought only from one firm - in the Japanese automobile industry. In contrast, dual sourcing of components is said to be more common in the west. In western-style dual sourcing a contract is awarded to more than one firm, each of which 
tools up to make the same part. In this latter system competititon between suppliers is evident for all to see, as any dissatisfaction on behalf of the purchaser can be signalled by a shift of orders to a second firm. Moreover, disruptions to production - due to employee strikes, for instance - can be either warded off or mitigated because a second source is immediately available.

But the notion that "single sourcing" is prevalent in Japan is not entirely accurate, for it takes the western definition and then assumes (in typical analytical dualist fashion) that Japanese structures are opposite to western ones. Behind what - from a western perspective - may appear to be a cozy form of single sourcing there lies in fact a different form of dual sourcing which is indeed central to the enforcement of competition within supplier chains. This form of dual sourcing involves awarding contracts for the same part (eg a wheel) for different models (eg Toyota Corolla, Toyota Carina) to different firms. One advantage lies in avoidance of wasteful duplication of capital equipment investments since each model-part is supplied by only one firm, and a second advantage lies in realization of economies of scale. But more importantly, this system allows purchasers to collate comparative data on cost, quality and delivery which can be used to secure better bargains in future, since each supplier knosw full well that it does indeed have a competitor, even if less directly than in western style dual sourcing. This Japanese-style dual sourcing provides an important framework for constantly reinforcing competitive pressures.

The competitive aspect here explains why Japanese analysts have stressed the positive aspects of the system even while western firms worry about the risks of reliance upon one firm from adoption of Japanese-style "single sourcing". Moreover, the average number of suppliers of each kind of part to assemblers increased steadily during the 1980s as assemblers increased their number of relations with suppliers. Indeed while each assembler's kyoryokukai contains one supplier of each kind of part, it is common practice also tu purchase this part from a firm that does not belong to the association. And conversely, even suppliers closely affiliated with a particular assembler may also supply several other assembly firms.

\section{C/ Spatial Organization of the Automobile Industry}

(These arguments are developed more fully regarding transport infrastructures in: Andrew Mair (1992 forthcoming) "Just-in-Time Manufacturing and the Spatial Structure of the Automobile Industry : Lessons from Japan. Tijdschrift voor Economische en Sociale Geografie vol. 83). 
Many commentators have remarked upon the particular spatial organization of production found in the Japanese automobile industry. Geographical concentration of production structures, the creation of regional spaces of production, the role of proximity and transportation infrastructures, the influence of the historic legacy of spatial organization in determining present patterns, continuing "ruralization" of production, alla are important to understanding the vital part played by spatial organization in influencing the daily functioning of Japanese automobile firms.

The geographically concentrated form of the Toyota City production complex outside Nagoya is often held to be exemplary of a specifically Japanese form of spatial organization in the automobile industry. At this location Toyota exerts a large measure of control over the reproduction both of its workforce and of the substantial portion of its supplier chain that is also situated there.

Japanese automobile firms have created "regional spaces of production" in which ties among firms in the production structure are so close that the assembly line has essentially been stretched out over regional space. The production structure is spatially focussed on central assembly plants, with the hierarchy of tiers in the supplier chain finding a counterpart in spatial organization : first-tier suppliers are usually physically closest to assemblers, second-tier firms are farther away, and so forth.

This concern with spatial organization reflects the prime role geographical factors play in facilitating close physical ties between firms, whether movements of personel on a daily basis -which allows for development of complex evolving relationships far more efficiently than mechanical or electronic information exchanges - or flows of components or materials (see Aoki's H-form discussion). geographical proximity between firms is highly prized, and longer distances can cause considerable problems in maintaining close daily relationships. However, geographical proximity is important not in itself but because it is one means to ensure proximity in time, eg the possibility of working with short lead times between orders from purchasers and delivery of parts by supplier firms.

Thus the importance attached to proximity is mediated by the nature of the distance, which in turn determines the time taken to traverse space. Moreover, poor physical infrastructures and transportation logistics disrupt even short distance relationships, making the time of deliveries unpredictable. Hence logistical planning in the Nissan production structure, for instance, which is regionally concentrated and focussed upon metropolitan Tokyo, nevertheless suffers considerably from debilitating traffic congestion in the Japanese capital. 
The historical-geographical development of industrialization in Japan continues to influence contemporary patterns of spatial organization. Toyota, which has actively moulded its own spatial structure at Toyota City, in fact remains exceptional rather than typical. And even Toyota's production structure remains firmly rooted in past patterns of industrial location. Thus many of its lower-tier suppliers are located in the closest metropolitan region of Nagoya. And a significant portion of its direct purchases still originate in the Tokyo region, much further away, but the historic heart of the automobile industry in Japan and retaining a wealthy infrastructure of supplier firms. Such past patterns have also influenced the spatial structures of firms smaller than Toyota and Nissan. Thus Mazda's Hiroshima base in western Japan remains spatially isolated from most important suppliers, while Mitsubishi's origin as a conglomeration of different producers is reflected in the location of its assembly plants in various cities. Other firms are located in smaller cities surrounding the main industrial complexes of Tokyo and Nagoya but are not strong enough in terms of market power to draw many suppliers to their vicinity so as to effectively create Toyota City style production complexes.

Finally we should note a continuing tendency to shift production to rural areas for reasons related to labour force availability and "quality". Toyota City itself was still a largely rural area as recently as the late 1950s, where recruits of peasant stock were viewed as ideal production workers. By the late 1970s firms further down the supplier chain were opening their new plants in rural districts where they could hire cheaper parttime peasant labour. And Toyota's first assembly plant outside Toyota City, due to open in 1993, will be located in a greenfield area on the island of Kyushu some 600 kilometers from Tokyo City.

\section{D/ Daily inter-firm relationships}

Daily inter-firm relationships refers to practices, analytically distinguished here from organizational and spatial frameworks (B and $\mathrm{C}$ above). Daily relationships involve linkages of information, personnel and semi-finished goods among firms, exchanges either directly related to production or in activities like collaborative research and developement. The organizational and spatial frameworks discussed above are intended to support these daily relationships (and also to support other activities internal to each firm). 
1. Just-in-time strategies for inventory and delivery : Just-in-time strategies of inventory control and parts delivery require close organizational and time-space linkages if they are to be implemented effectively. Firms must be familiar with each other organizationally, be well versed in each other's needs and know how to react if problems arise. In cases where kanbans are used to communicate fresh orders to suppliers the need for timespace proximity is doubled since delays in return transit (of kanbans) will either magnify disturbances to smooth production at supplier firms or enforce a system of buffers antithetical to just-in-time principles.

Kanbans are not, however, necessary; an electronic data transfer system can communicate orders without regard to spatial proximity, thus already halving lead times compared to a kanban system. Nevertheless Nissan, for instance, despite its spatial concentration in the Tokyo region, has found that continued reduction of stocks towards just-in-time deliveries impedes production planning since the congested metropolitan environment causes all sorts of unpreditable delays.

It is important to recognize that there are different forms of just-in-time planning, appropriate to different components and materials, and therefore requiring different organizational and spatial structures. The oft cited "classic" case of a "total" just-in-time system, involving manufacturing of parts simultaneously with the automobiles into which each part will be inserted, is production and delivery of seats by a supplier company. Here the purchaser orders seats only hours in advance of their assembly into automobiles, which requires the seat supplier to manufacture exactly the seats ordered and deliver them directly to the production line in small batches and in exactly the right order for them to be fitted into automobiles on the assembly line. Logistical tasks are complicated when the automobiles and hence the seats are lined up in a certain order varying by colour, variant and often model - that is only known a few hours in advance. problems in the assembly plant with a particular paint colour may mean short -notice changes in orders for parts like seats which match body colours. Clearly in this situation very close organizational and spatial ties are necessary to avert problems.

By contrast with this "total" just-in-time system, supply of sets of small bolts which only vary by model, are simple to store and cheap to transport (but only in bulk), by no means requires a close daily relationship among firms so long as high quality parts are assured. This example, in many respects the opposite of the seat example, warns us not to suppose that a total just-in-time system makes sense for all automobile parts. Here, organizational and spatial proximity are far less relevant. 
When problems of parts quality, delivery timing and so on do arise purchasers take a keen interest in their resolution. This can entail immediate provision by the supplier of replacements parts and also the despatch of trouble-shooting engineers from the assembly firm to discuss resolution of the problem. Larger-scale manufacturing restructuring projects - such as introduction of new logistical systems demanded by the purchaser - may be difficult for supplier firms to undertake without outside assistance. Managerial and technical teams from the purchaser may again be despatched (rather than calling in western-style consultants). In these cases too spatial proximity is beneficial, not only for speedy delivery of replacement parts but also for short-term changes to employee commuting patterns necessitated by collaborative inter-firm problem-solving techniques.

2. Research and development : The role of supplier firms in actively researching and developing both new production processes and new products has been increasingly emphasized in literature on the role played by the supplier chain in Japan. Development of new products has become vital to the global competitive strategies of all firms in Japan, with models now systematically replaced every four years.

Assembly firms have increasingly passed responsibilities for design of components along to supplier firms, effectively integrating research and development into the production structure. The possibilities of "design for ease of manufacture" are thereby much enhanced because the designer and manufacturer of the part are one and the same. Lead times for new products can also be reduced by parallel research efforts (ie suppliers are given overall parameters within which to work, and detailed design can thus continue on several fronts at once). At the same time, purchasers may inject an element of competition into the system by requesting more than one supplier to participate at certain stages of the development process.

This form of systemic research and development clearly requires a high degree of collaboration among firms, as well as trust that confidential ideas and desings will not be leaked to other firms. It also implies that suppliers maintain sufficient resources tomount effective research and development programmes and are not overly "exploited" by purchasers. Supplier firm engineers may participate as guests in assembly firm research and development teams, gaining the relation-specific knowledge that is enhanced the longer the relationship continues. Close personal contact is greatly facilitated by geographical proximity of firms sufficient to allow flexible daily commuting patterns for employees. 
3. Product innovation and flexible divisions of labour : The pattern of demand for particular components and materials is frequently altered by model changes and other product innovations such as new types of components (eg electronic, electrical) and new materials (eg plastics, alluminium). Moreover, the relative advantages of different supplier firms in different types of production (eg capital intensive or labour intensive, different supplier firms in different types of production (eg capital intensive or labour intensive, different materials) may be quite variable. Nevertheless there is considerable benefit from maintaining existing inter-firm relationships over time instead of chopping and changing as needs shift, which would introduce a measure of uncertainty related to product change rather than a firm's performance.

In this potentially contradictory context divisions of labour within the supplier chain must be flexible. For instance, it is not uncommon for a supplier firm first to outsource a particular part or sub-process to other supplier firms but later to bring it back in house while a different part of the process is outsourced. The supplier chain begins to function more as a flexible network than as a rigid hierarchy. In this network form the organizational and spatial frameworks discussed above come into play as mechanisms of governance, ensuring that divisions of labour can efficiently be altered without impediment or resistance.

4. Attacking costs : There is constant pressure to reduce prices of parts, usually at least once per year. However, the focus is usually on how supplier firms can reduce costs of production rather than profit margins. And the reward for meeting targets is near certainty that future contracts will be awarded indefinitely. Dual sourcing Japanese style acts as a means of comparing prices to ensure competitiveness without seeking to gain confidential information on prices at other firms or demanding open bidding for new contracts. "Competition in the North American automobile market is going to become very tough by the early 1990s. The firms which succeed will be those with the best supplier nerwork" (Honda engineer seconded to Japanese automotive supplier in Ohio, 1988; author's interview). 


\section{PART II : HONDA'S NORTH AMERICAN INVESTMENTS AND PARTS SOURCING PRACTICES}

In this part of the paper we first describe the extent of Honda's direct investments in North America and then examine the firm's practices of parts sourcing for its North American facilities : ie whether parts are imported purchased from "domestic" ie North American firms or purchased from "supplier transplants" ie Japanese-owned factories located in North America. The object at this stage is to describe Honda's parts sourcing practices factually in order to gain a picture of the extent of Hondas' North American production structure. Explanation of these practices will be dealt with later in the paper, in discussion of organizational and spatial frameworks and of daily inter-firm relations, to which they are closely bound.

\section{A/ Honda's North American investments}

In late 1982 the Honda Motor Company became the first Japanese firm to manufacture automobiles in North America, at a new plant near Marysville, Ohio. At the time, many observers both in Japan and in North America were still arguing that Japanese automobile firms were "reluctant multinationals" and that Japanese production techniques could not be implemented outside Japan.

Since Honda's initial decision to invest in North America in 1977 tomanufacture motorcycles at the same site near Marysville - the firm hs constructed several factories and other facilities for automobile production. Beginning with the Marysville automobile plant opened in 1982, Honda has constructed an engine and mechanical components plant (Anna, Ohio), more than doubled the size of the Marysville plant, built an assembly plant (East Liberty, Ohio), built Honda Engineering facilities (Marysville) and Honda Research and Development facilities (California and Marysville), and has purchased from the State of Ohio a large existing test track on the perimeter of which all the Marysville and East Liberty facilities are located (see table 1). 
Table 1 : Honda in North America : Selected Chronology

1977 Announcement of motorcycle assembly plant, Marysville Ohio

1979 Motorcycle production begins

1980 Announcement of automobile assembly plant adjacent to motorcycle plant, to assemble Accord model

1982 Automobile production begins

1984 Major expansions announced : doubling size of automobile plant, Honda Engineering and R\&D facilities, Anna Ohio engine plant, automobile assembly plant at Alliston Ontario

1986 Announcement of further 20 percent capacity increase for Marysville automobile assembly plant, 2nd line at Marysville starts to make Civic model, Anna plant starts to make Civic engines, Alliston plant begins Accord production

1987 Announcement of further expansion plans : to build 2nd US assembly plant at East Liberty Ohio, to expand Honda Engineering and Honda R\&D at Marysville, to increase Anna output to meet $85 \%$ North American engine needs. Begins production of 2-door Accord at Marysville.

1988 Begins exports of Marysville Accords and motorcycles to Japan. Alliston plant adds production of 3-door Civic model.

1989 Production of Civics begins at East Liberty plant.

1990 Production of Accord station wagon derivative begins at Marysville.

1991 Begins export of Accord station wagons from Marysville to Europe.

This series of investments has enabled Honda to move rapidly towards the goal it prochaimed in 1987 of developing a "self-reliant" automobile production firm in North America. That Honda North America is steadily gaining in operational independence was confirmed by the 1990 launch of the Marysville-produced Accord station wagon, into the design of which US-based R\&D staff reportedly had a large input. But manufacture of this vehicle had been preceded by a series of less noticed moves, such as conceptualization of the "sporty" Civic CRX variant in California, production of the 2door variant of the Accord model only at Marysville (and not in Japan) for sale in North America and Japan, and manufacture by Honda Engineering at Marysville of sets of stamping dies and other capital equipment for the Alliston and Marysville assembly plants.

\section{B/ Patterns of parts sourcing}

The organizational and spatial frameworks and daily inter-firm relations in Honda's North American production structure in which we are primarily interested are intimately related - with causality running in both directions - to the firm's patterns of 
parts sourcing (levels of "local content", what kind of parts are purchased from what kind of firms). The historical development of parts sourcing practices at Honda, as well as the great political controversy this (together with the practiceys of other Japanese transplants) has aroused, are examined in considerable detail by Mair (1991). Here we summarize pertinent aspects of that discussion, momentarily and artificially separating it from questions of organization, space, and daily inter-firm relations.

\section{Two phases of parts sourcing}

During the first years of automobile production , 1982-1986, levels of local content remained quite low (40-50 percent by North American measures; stricter than the loose measures used in Europe). In these years Honda concentrated on establishing and then expanding its assembly operations, while carefully probing the capabilities of domestic supplier firms. At this stage local purchases were mostly limited to two types; on the one hand bulky materials (eg steel and glass) and generic components purchased from some of the earliest established Japanese transplant suppliers.

Since 1987, however, local purchasing has boomed. In part this is because Honda has increased its contacts with domestic firms; small companies stamping metal components or moulding plastics, for instance. But increased local content is due largely to purchases Honda makes from many of the over 300 Japanese automobile supplier firms that descended on the North American midwest during the second part of the 1980s. By the late 1980s Honda was purchasing a variety of specific components from more than 80 supplier transplant firms.

\section{First-tier purchasing}

The quantitative pattern of first-tier (ie direct) purchases that hadresulted by 1989 was revealed by a University of Michigan study released in 1991. Of parts purchased by Honda to build automobiles in Ohio, 20 percent by value are bought from domestic firms, 33 percent from Japanese supplier transplants, and 47 percent are imported (Chappell, Lindsay, 1991 : Parts study says Honda is shunning U.S. suppliers. Automotive News May 13th, pp. 2, 52).

Dividing particular parts by type of supplier reveals a striking disparity between the kinds of parts purchased from domestic firms and those purchased from Japanese transplant firms (table 2). 
Table 2 : Components and materials supplied to Honda by first-tier domestic firms and Japanese supplier transplants - sample

From domestic firms

batteries

carpeting, flooring and trunk mats

paint

parts carts

plastic products

plastic products

rivets

sheet steel

sheet steel

stamped parts

stamped parts

tooling components

batteries
jacks
paint
plastic products
plastic products
plastic resins
robot repair
sheet steel
speaker assembly
stamped parts
stamped / welded parts
trim

From Japanese supplier transplants

aluminium die castings

assembled seats

assembled wheels

automobile keys

belts and hoses

brake assembly

brake line tubing

arm bushing and joint assemblies

assembled seats

automatic speed control devices

bearings

body part stampings and weldings

brake lines

catalytic converters

chemically treated replacement parts

coil suspension springs

condensers, evaporators and tube assemblies for air-conditioners

condensers, evaporators and heat exchangers for air-conditioners

door locks

door sashes

engine ducts and rubber mouldings exahust systems

fitted windows

floor mats

front lamp assemblies

generators and alternators

fuel injectors

hose and tube assemblies

heat exchangers

indoor car panels and sun visors

instrument clusters for dashboards

interior fabric panels, door and roof panels

interior parts

plastic injection moulded parts

plastic compounds

plastic interior decorative parts

plastic moulding, interior door panels

plastic parts

plastic parts for windscreen washers

power steering systems

power window motors

pressed metal parts, engine mountings, bolts and brackets

prototype parts for new models

radios and cassette players

rubber weather stripping

sheet steel

shock absorbers

stabilizer bars

radiators

rubber engine mounts

seat belts

sheet steel

sound control products

stamped and welded parts 


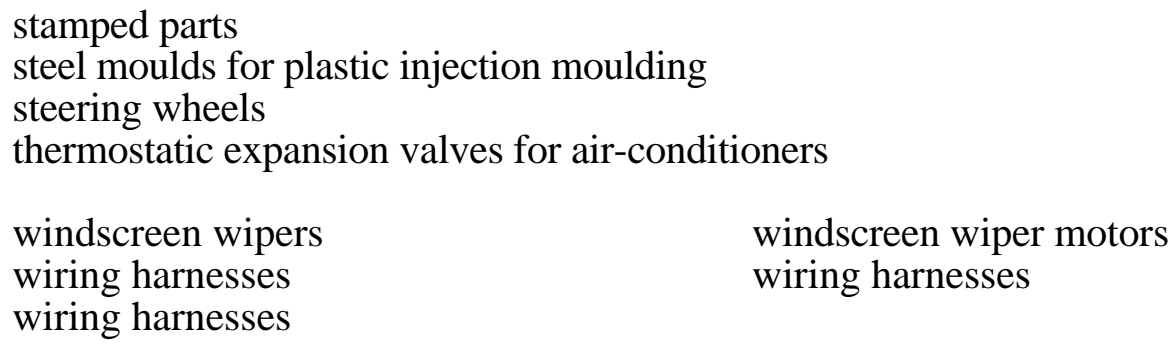

Source : Author's research, Honda, press sources (see Mair, 1991)

Note : Some firms supply more than one product; where these are very different they are listed separately. Known second-tier products are not included here.

As the table indicates, domestic firms concentrate on supplying basic materials and simple components, while Japanese transplant suppliers manufacture a range of parts including the most complex components. Domestic firms that wish to supply Honda with complex components have generally been obliged toform joint ventures with Japanese firms. According to Honda's own claims to a 75 percent local content by the early 1990s, 25 percent by value of the average Honda automobile made in North America is still imported from Japan, and a large proportion of these imports consists of the most complex electronic and mechanical components.

Honda's engine and mechanical components plant at Anna, Ohio weighs equally with the supplier transplant firms in contributing to the North American content of Honda automobiles assembled there. The plant produces alluminium and steel castings, it machines and assembles engines, and manufactures many engine components (eg cylinder sleeves, cylinder heads, pistons, cranksafts). Other major mechanical parts, such as automatic transmissions, suspensions, brake disks and brake drums are also made at Anna. The vital significance of the Anna plant is reflected in the fact that it accounts for 34 per cent of Honda's \$2 billion investment in North America.

\section{Second-tier purchasing}

Quantitative and qualitative patterns of second-tier parts sourcing reflecting purchasing by Honda's first-tier transplant suppliers are revealed by the sample in table 3. 
Table 3 : Honda's second tier sourcing : origin of components and materials for Honda's Japanese supplier transplants

\title{
$\underline{\text { From Japan }}$
}

aluminium wheels all components at start

components

door components

finished parts

oil-less bearings

plastics and vinyl

rubber parts

steel

tubing

\author{
all at start \\ bolts \\ components \\ electrical components \\ metal components \\ plastic components \\ precision machine parts \\ seat belts \\ tubing \\ washers
}

From transplants in North America

aluminium wheels

chrome plating for molds

electrical components

fabric

plastic pellets

seat covers

seat frames

tyres

automotive belts

electric motors

electrical components

plastic components

seat covers

steel

steel wheels

window

(To Anna engine plant)

accelerator cable

chassis and suspension components

fuel injectors

power steering systems

$\mathrm{V}$ belts

brake components

engine valves

gaskets

transmission controls

wire springs for transmissions

\section{From domestic firms in North America}

aluminium ingots

aluminium ingot

box

cardboard

castings

catalyst for catalytic converter

chemicals

chemicals

cloth goods

cloth goods

fabric

foam

glass

insert / facing material

moquette

paint

plastic buttons aluminium ingot

asphalt

box

carpets

castings

chemicals

chemicals

chemicals

cloth goods

cord welt

foam

foam pads

hardboard

material / piece goods

padding-barrier

plastics

plastic materials 
oil

plastic pellets

polymers

rubber

sheet metal

sintered iron

steel

steel tubes

treated fabric

tyres

chemicals

vinyl

wire

(To Anna engine plant)

aluminium ingots

specialty steel bars plastic pellets

plastic suspenders

rubber material

processed steel

sintered iron

springs

steel plate

thread

tyres

urethane

vinyl

windlace

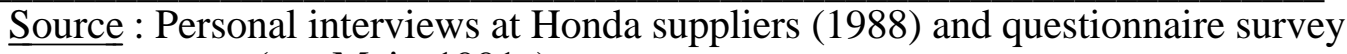
(see Mair, 1991a).

The proportions of domestic firms vs. Japanese firms participating in the Honda production structure at second-tier level is the inverse of that revealed at first-tier level by the University of Michigan study, with many more domestic firms involved at this level. There is nevertheless a significant supplier transplant presence at second-tier level, especially formanufactured sub-components. Moreover, at second-tier level the same qualitative distinction is evident as was apparent at first-tier level : between domestic firms supplying basic materials and simple parts, and supplier transplants supplying more complex components.

\section{Parts sourcing : summary}

The pattern of parts sourcing at Honda's North American production structure reveals that a very significant local supplier chain has been developed. Japanese-owned firms account for the bulk of manufacture of specific components, more prevalent at first-tier level, while domestic firms are mostly involved in manufacture of materials and generic parts, more prevalent at second-tier level. While Honda makes most of its complex mechanical components in North America at Anna, the manufacture of many other complex parts, electronics in particular, has not yet been transplanted into the North American production structure. 


\section{PART III : ORGANIZATIONAL FRAMEWORKS}

In this part of the paper we investigate the organizational frameworks that Honda and its suppliers have built in North America in order to facilitate their daily inter-firm relations. Underlying the discussion is the question of the extent to which these frameworks have been modelled on Japanese experience transplanted - or have been changed to suit North American circumstances - transformed.

Several notable features of the organizational framework that Honda has instituted to govern its assembler-supplier relations make for interesting comparisons with the Japanese model. While these features are inter-related, they can usefully be analysed under five headings : 1) tiering arrangements among supplier firms, 2) interfirm divisions of labour and collaborative links, 3) specific arrangements designed to ensure competition among supplier firms, 4) joint venture arrangements between firms, 5) formal organizational links.

\section{1) Tiering arrangements}

The arrangement of tiers of supplier firms in Honda's North American production structure has several distinctive features, including a shallowness in comparison to Japan, different roles for domestic vs Japanese firms, and a network-like structure that points away from easy categorization of firms into specific tiers.

In the first place, in general the multiple tiering arrangements characteristic of Japan are not evident. Instead, there is a more shallow structure of two to three tiers of suppliers beneath Honda. At this depth the production structure has already reached manufacturers of basic materials. In some instances, however, establishment of a detailed division of labour among supplier firms has resulted in the appearance of more tiers than is traditionally the case in North America. Thus seat manufacture in western firms has traditionally been undertaken within the final automobile assembly plant, including sewing and assembly (although this is changing rapidly due to outsourcing and to mimicry of Japan). By contrast, Honda's North American production structure includes separate firms that respectively sew materials and assemble seats. These are inserted as tiers between the fabric manufacturers and Honda's assembly plants. 
A second feature of Honda's tiering arrangements is that Honda and its first-tier supplier transplants have rooted themselves firmly into the existing North American industrial infrastructure of first - and second - tier domestic manufacturers of basic materials. This arrangement is symbolically represented in the main part of figure 1 . Thus the transplantation of Japanese supplier firms to North America involves mostly manufacturers of specific automobile components at first-tier (and sometimes secondtier) levels. By contrast, basic materials and simple parts are largely purchased from the broad industrial infrastructure that serves many North American industries.

A notable modification of this pattern of purchasing materials from domestic firms results from the large-scale investment in North America by Japanese steel and tyre companies that have taken over or formed joint-ventures with North American counterparts. Japanese firms in these sectors have acted to prevent loss of their automobile industry markets, and their move into North America has been permitted by North American firms that are unable to produce as efficiently and to the high quality standards demanded by the Japanese assemblers in North America (joint ventures are further discussed below).

The end result is that Honda has almost entirely bypassed the traditional North American automotive supplier industry, by bringing from japan its suppliers of specific automobile components and by limiting its purchases from domestic firms largely to parts that are not specific to automobiles. This evasion of the domestic automotive parts industry is emphasized by another pattern : on several occasions when Honda has sought to purchase automobile parts from domestic firms, it has turned to, and helped to convert, firms that were not previously part of the automotive sector (see below).

The political anger of the domestic automotive supply sector and its political allies has focused on such patterns (see Mair, 1991). On the other hand it should be noted that because of the high levels of vertical integration at North American assembly firms, particularly at General Motors and Ford, for many automobile parts there are few or no independent North American suppliers to which Honda could have turned. In several cases, the larger independent domestic components manufacturers have formed jointventures with Japanese firms to supply Honda (see below).

The third notable feature of Honda's tiering arrangements is their complexity, particularly where Japanese supplier transplants are involved. As noted above, commentators ascribe to the automobile industry in Japan a system of distinct and clear tiers (though this is put in doubt by some descriptions of more complex inter-firm 
relations in Japan (Ikeda) ). By contrast, Honda's North American production structure involves many networking arrangements in which firms occupy more than one tier often first - and second-tier levels simultaneously - because they make more than one part. Some of the resulting complex web relationships are described in the examples of inter-firm divisions of labour given below.

\section{2) Inter-firm divisions of labour and collaborative linkages}

Three examples attest to the complex nature of divisions of labour and collaborative linkages among firms in the Honda production structure. The first example illustrates a deepened division of labour via insertion of multiple tiers into a supplier chain. The second and third examples reveal a complicated network form of inter-firm relations rather than a crisp linear tiering structure.

The first example is windscreen manufacture. During the early 1980s Honda had purchased windscreens from the domestic firm PPG, which also made the glass. When PPG proved unable to resolve persistent quality problems, Honda asked the major Japanese supplier Asahi Glass to establish transplant operations, which opened in Ohio in 1986. Now a first-tier transplant factory adds trim to the windscreens to prepare them for final assembly, while a second-tier plant located in the same town occupies the pivotal placein the supplier chain, making the windscreens to a Japanese firm in Japan, for assembly into vehicles that are then exported to the United States.

The second example is a joint-venture transplant that makes several different plastic parts for Honda. The Japanese supplier firm involved was initially reluctant to construc a transplant factory. Less that one year after production had started in 1987, however, it had become involved in a complex web of inter-firm linkages (see table 4). Not only is the transplant linked to its major customer, Honda, and to its domestic firm suppliers of raw materials, but it has developed an intricate nexus of relations with other Japanese supplier transplants so that the factory occupies diverse niches in the supplier chain at both first - and second-tier level. Moreover, a domestic firm that also supplies Honda with plastic parts, and which is a potential competitor, pushed to become involved as a minority partner. 
Table 4 : Cooperative linkages developed by a new supplier transplant

With Honda :

1. Japanese firm enticed to construct transplant by Honda financial and organizational aid. Honda owns 35 per cent of transplant, Japanese partner, which is manager, owns 55 per cent.

2. Transplant supplies Honda with three very different painted plastic parts.

3. Vice-president seconded from Honda to ensure that "Honda Way" is followed.

4. Honda Engineering approval required for all new sub-components sourced in North America, down to nuts ans screws.

With domestic firms

1. Domestic firm (150 km away) that has long supplied Honda and domestic assemblers with other plastic parts asked to, and became, 10 per cent jointventure partner in transplant and sought further technical collaboration.

2. Bulk raw materials purchased from giant domestic firms and also from small domestic firms.

$\underline{\text { With other supplier transplants }}$

1. Complex part used in sub-assembly bbpurchased from transplant A (100 km away) which also supplies Honda and other supplier transplants directly.

2. Sub-component purchased from transplant B (130 km away).

3. Manufactures sub-component used by transplant C (190 km away) that supplies component to Honda.

4. Waste materials processed for reuse by transplant D, (40 km away), which also supplies Honda.

\section{With Japan}

1. One year after production started nearly all the dozens of very small non-plastic parts required are still imported from Japan; sometimes have to be flown in to regional airport.

2. Engineers to repair some machinery fly in from Japan, causing significant delays and hence difficulties for transplant management.

Source : personal interview.

A third example is drawn from seat manufacture, the longest established osupplier transplant activities. Figure 2 reveals inter-firm relationships focusing on Bellemar Parts (Marysville plant), Honda's major seat manufacturer. Bellemar Parts Marysville is located within sight of the Marysville assembly plant. It should be stressed that this diagram includes only known relationships, derived from interviews at two of the supplier transplants involved and from survey responses from four other supplier transplants. It nevertheless presents a facinating picture of inter-firm linkages. 
Since Bellemar manufactures more than one component its production network includes areas of component manufacture besides seats, such as interior trim, wheels, and brake tubes. Bellemar is thus connected to a diverse set of firms, linking it to supplier transplants making components and to domestic materials manufacturers (following the general pattern shown in figure 1) as well as to other domestic and transplant automobile assembly plants besides Honda. It becomes quite difficult to categorize firms as either first-tier or second-tier. As in the previous example, some of the firms are also linked with each other via financial holdings.

\section{3) Ensuring competition}

In several cases supplier firms have been brought into Honda's North American production structure to at once collaborate and compete with each other. The result is a structure of controlled but quite evident competition in which the existence and identity of a particular competitor is evident for all to see. Moreover, the competitor's capabilities are also likely to be well understood, because the firms are linked to each other collaboratively. This is dual sourcing Japanese style.

Thus in the second example given above, Honda encouraged establishment of the transplant firm to manufacture plastic parts even though Honda had an existing relationship with a domestic firm making other plastic parts. At the same time the domestic firm became a joint-venture partner in this potential competitor. The thrid example reveals an even plainer instance of dual sourcing Japanese style. Honda has provided Bellemar with a competitor by purchasing seats since 1988 from a second transplant seat manufacturer ("firm X"), part-owned by a different Japanese seating firm fron the one involved at Bellemar. Firm X was initially established to provide Honda with special types of seats for more expensive models, but it clearly represents a potential threat to Bellemar. The competitive relationship between the two seating transplants has, however, been nuanced by Honda's requirement that firm $\mathrm{X}$ deliver its seats directly to the small warehouse within Bellemar's factory in which Bellemar places its seats (and now firm X's seats as well) in the correct sequence for final assembly at Honda. This gives the two firms involved a point of contact and enforces collaboration between them. American managers at both plants are quite aware of their peculiar relationship.

Turning on its head the notion of dual sourcing japanese style - with its dependence of supplier firms on assemblers - it is notable that many transplant suppliers to Honda also sell components and materials to other assembly firms, thus broadening their markets. Indeed it is important to remind ourselves that the Honda production 
structure does not stand alone. Not only is it integrated into a materials infrastructure of domestic firms, but it shares elements of a broader Japanese automobile firm production structure with other firms like Toyota and Nissan. Thus table 5 reveals that Honda's supplier transplants also sell to a variety of other Japanese firms in North America.

Table 5 : Honda transplant suppliers : other transplant assemblers supplied - sample

Transplant assembler

Nissan

Mazda

Toyota

Diamond Star

Subaru-Isuzu

CAMI

NUMMI

\section{Honda suppliers with links}

14

13

11

Source : Mair (1991).

Forging links with more than one purchaser continues the trend noted earlier for supplier firms in Japan to be less tied to a particular assembler than is portrayed in the old orthodox view of assembler-supplier relations. Multiple linkages has two advantages; enabling economies of scale to be reaped via larger outputs, and making the firms less dependent on a particular purchaser.

On the other hand clearly there is a category of supplier transplants that are quite firmly tied to honda exclusively or almost exclusively. Indeed it is possible do divide Honda's supplier transplants suppliers into three broad categories with reasonable accuracy. Thus category A includes those firms that can be considered "exclusive" Honda suppliers (defined operationally as 90 per cent or more of output going to Honda). The broad category B includes firms supplying two or more assemblers ( 89 per cent to 11 per cent of output to Honda). Category $\mathrm{C}$ encompasses those firms which are only minor suppliers to Honda (10 per cent or less of output). Of a sample of 76 supplier transplants for which solid information is available, there are thirty-two supplier firms in category A, 29 in category B, and 15 in C, revealing a large number of specialist suppliers to Honda alongside a larger number of more diversified transplants. 
Clearly this division represents a particular slice through time (in this case 1988) in an evolving set of supply structures. Evolution towards greater diversity is likely given the common expectation of maintaining linkages once established but also seeking new markets (Personal interviews at Honda suppliers, 1988).

\section{Joint venture transplants}

A substantial proportion of the Japanese transplants supplying Honda are financial joint ventures (JVs) between different firms. Twenty-one ( 28 percent) of 76 identified transplant suppliers to Honda are in fact part-owned by domestic firms, as in the first and second examples of inter-firm linkages above. A further 13 (17 percent) involve Japanese firms that have joined together for transplant investments.

Patterns of JV relationships have shown significant change overr time. This is revealed in Table 6, which separates a categorization of JV transplant types into two time periods, 1982-1987 and 1988-1990, according to dates of production start-up. The table reveals that the proportion of JVs among all transplants has increased marginally between the two periods. More important, however, are some clear shifts in JV ownership patterns. First, the proportion of supplier transplants that are JVs involving only Japanese firms declined from 24 per cent to 9 per cent. This decline is partly because during the 1982-1986 period, Honda's low outputs had encouraged factorysharing by different Japanese supplier firms to overcome problems of economies of scale, whereas after Honda's post-1986 doubling and quadrupling of original maximum output levels this was no longer a problem. Second, the proportion of all supplier transplants with no domestic involvement declined from 83 to 60 per cent. Third, the proportion of Japanese-domestic JVs with Japanese majority ownership has remained constant, and so the observe increase from 17 to 40 per cent in supplier transplants that are JVs with domestic firm involvement has consisted entirely of a growth of equal partnership and domestic-majority JVs, from only 2 per cent of supplier transplants in the earlier period to 23 per cent in the later period. 
Table 6 : Joint ventures among Honda transplant suppliers - changes over time

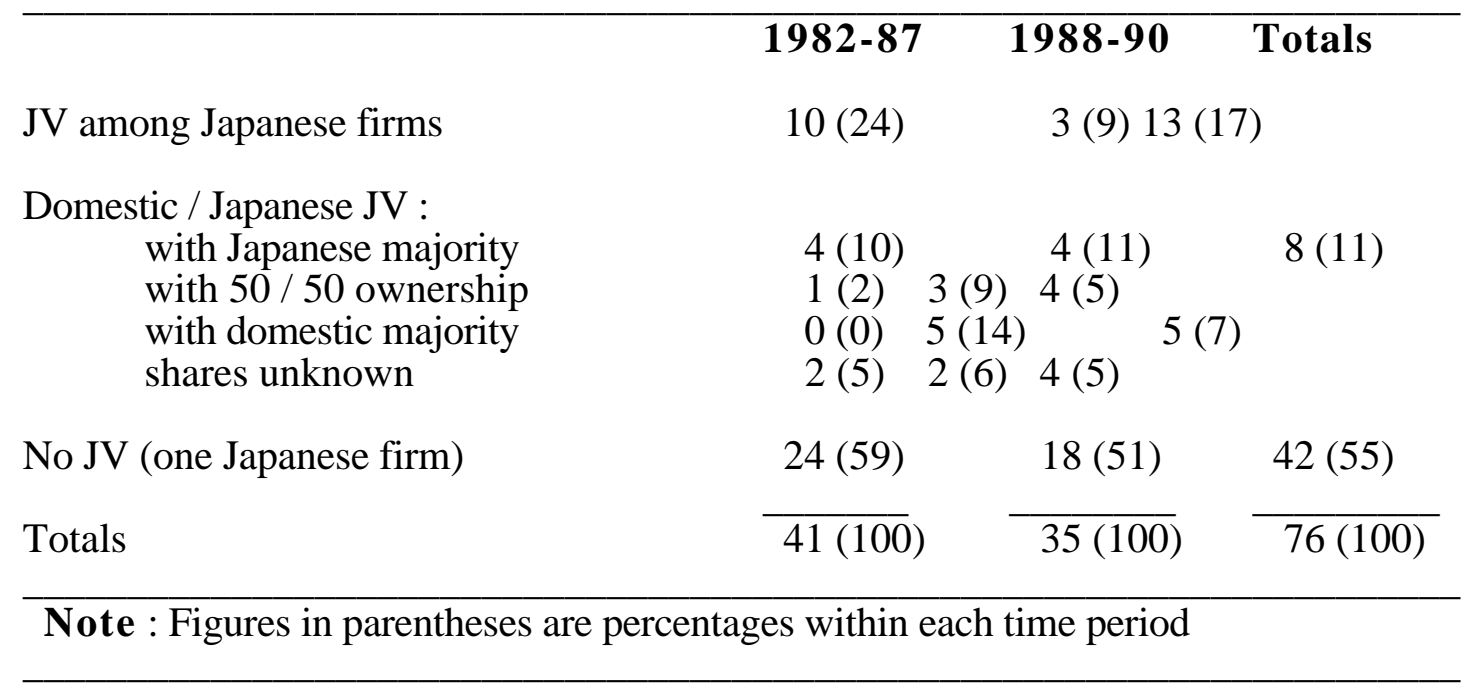

From this analysis it appears that there has been a shift over time towards allowing domestic suppliers to establish links with Honda, but that many domestic suppliers still find it necessary to form JVs with Japanese firms. Examination of individual JV cases reveals that, after 1988, several major independant domestic suppliers formed 50 / 50 or domestic-majority JVs to supply Honda, often selling specific mechanical parts components. Thus domestic firms Dana Corporation, ACCO Controls and TRW built new plants with japanese partners to produce gaskets, transmission control cables and engine valves respectively.

Why there has been this shift towards including some domestic firms that produce higher value specific components via JVs is unclear. Possible explanations onclude political sensitivity on Honda's part, satisfactory adoption of new manufacturing techniques by domestic firms, or agreement that japanese partners will manage the new plants constructed.

Some Japanese-domestic JVs include domestic firms that had been supplying Honda since 1982-1983, often with vital materials (glass, steel, tyres), but which were subsequently pressed by Honda to cooperate with Japanese suppliers in order to improve product quality. As we saw in the second example of collaborative linkages above, while it was disappointment with the quality of windscreens supplied by the domestic firm PPG that led Honda to request Japanese window manufacturer Asahi Glass to establish two window manufacturing transplants, PPG was included as a 20 percent JV partner in both plants to encourage it to learn how to improve product quality. 
Another Japanese-domestic JV includes Inland Steel, one of Honda's three original domestic sheet steel suppliers. Inland received considerable technical aid from the Japanese steel manufacturer Nippon Steel during the mid 1980s, for improvement to the quality of steel supplied to Honda, before announcing construction of a new sheet steel plant as a JV with Nippon Steel, soon followed by announcement of a second and a third new JV steel plant. Total new investment in the three plants will be $\$ 900$ million, with enough steel produced to build 2.5 million cars per year, over 20 per cent of total annual automobile and light truck production in North America.

Other Japanese firms have entered the basic North American steel and rubber industries by investing in JVs, though usually by investing in existing plants. In 1988 Kawasaki Steel entered a JV by buying 70 per cent of Armco, a second Honda domestic sheet steel supplier. Similarly, Dunlop, one of Honda's three tyre suppliers in North America, was purchased by Sumitomo Rubber in 1986.

\section{Formal organizations}

Already seen instances of financial links as a common mechanism in each of three examples above.

Notes : substantial criticism of this in early 1990s as latest political wave against the Japanese in USA, following local content complaints etc, ie favouritism bordering on monopoly; leads to government investigations, apparently indeteminate results.

In Japan Honda hasn't the spinoffs ot Toyota and Nissan. Honda eschews the formal organizations in Japan.

On associations, note "Honda suppliers day" and also meetings of human resources people on regular basis.

Examination of individual cases in North America seems to reveal quite a divergence; clearly some are closely Honda-related, are semi-spinoffs eg Bellemar. Others are quite independent, eg Stanley, others still are independent of any one J firm (note how many supply also other firms). Others had to be persuaded to come to North America because didn't want to. 


\section{PART V : INTER-FIRM PRACTICES WITHIN THE HONDA JIT REGION}

Inter-firm practices within Honda's North American JIT region fall into several categories. We will examine different practices in turn :

1. Inter-firm just-in-time.

2. Quality control.

3. rapid response to changing orders.

4. reducing prices of parts.

5. Moving personnel within the JIT region.

6. Integration of $R \& D$ into the production structure.

7. Honda Engineering and supplier firms.

8. interventions into other firms.

9. Reorganizing the inter-firm division of labour.

10. Dealing with domestic suppliers.

Together with, of course, activities strictly internal to each firm (and the point is that in this system what is strictly internal is minimized by a deep division of labour and by very close inter-firm relationships) all these practices taken together constitute the Honda production structure as the integrated manufacturing unit that we are labelling a JIT region. In each practice there is a remarkable degree of collaboration between Honda and its suppliers and among the suppliers themselves, which is why it is so appropriate to speak of the Honda production structure as an integrated manufacturing unit. In each practice too the organizational and spatial frameworks discussed above find their role in governing iner-firm relations.

\section{Inter-firm just-in-time}

\section{a) First-tier relations}

Twenty-two of 24 (92\%) transplant supplierss whose major customer is Honda state that they deliver parts to Honda according to just-in-time (JIT) scheduling. Frequency of deliveries nevertheless varies greatly, form every half-hour or every two hours for components like seats, wheels, fuel tanks, or windows, to every day or every two and a half days for small metal stampings, small trim items and paint concentrates 
(see table 9). Even the two of twenty four firms that claim not to be delivering parts JIT still despatch sets of parts once and twice daily respectively.

Table 9 : Deliveries per (16 hour) day by transplant suppliers in the Honda JIT region vary by part supplied

\begin{tabular}{lcc} 
Part supplied & Deliveries per day \\
\cline { 2 - 2 } $\begin{array}{l}\text { gas tanks } \\
\text { rubber engine mounts }\end{array}$ & 28 \\
windows & 8 \\
fabric and seat covers & 6 & \\
steel wheels & & 6 \\
large plastic moulded parts & 5 \\
instrument clusters & 4 \\
steering wheels & 4 \\
windshield wipers & 4 \\
brake line tubing & 3 \\
brake components & 2 \\
seat belts & 2 \\
shock absorbers & 2 \\
wiring harnesses & 2 \\
automotive belts & 1 \\
rubber weathers stripping & & 1 \\
seat covers & & 1 \\
shelfing & & 1 \\
small metal stampings & \\
plastic interior panels & 1 & \\
seat parts & & 0.6 \\
colour concentrates & & 0.6
\end{tabular}

In some cases a full system of sequential JIT manufacturing is in operation. Here, parts are manufactured at the supplier in the same sequence they will be installed in cars; on the assembly line this is only possible for parts that will be installed towards the end of assembly and where there is therefore sufficient lead time after final sequencing of vehicles to manufacture and deliver the parts for installation. And it is only necessary for parts that vary according to colour, for instance. Hence seating is the example often quoted. Indeed Bellemar Parts, the primary seat manufacturer, manufactures and delivers seats within three hours of receiving its order from Honda, although proceedures have been complicated by the addition of a second seat supplier and the need to integrate its seats at Bellemar.

Levels of inventories of completed parts vary greatly. Thus one seat supplier has space for only 30 seats at its shipping area, while a supplier of plastic parts maintains a 
one and a half day inventory, partly because many subcomponents come from Japan and the firm wants to avoid risks.

Two supplier transplants located in southern states have adopted what they call a "modified JIT system" due to the distance to Honda; one, which was located in the south primarily to serve other transplants, utilizes a warehouse close to Honda as an intermediary location. The other firm delivers less frequently than it might otherwise do because of the distance involved.

Indeed the spatial framework appears to be strongly related to JIT deliveries in the Honda production structure. There is a clear relationship between frequency of delivery and distance from Marysville. We should not expect a perfect correlation, since other factors influence both delivery frequency (nature of product, nature of manufacturing process at purchaser) and location of linked firms (labour markets, location of other purchasers, other reasons for proximity to customer). Nevertheless a striking relationship can be observed in the rough data of figure 9 , which displays delivery frequency against a broad measure of transit time. Thus for firms located between 30 minutes to 2 hours away from their customer, the mean number of deliveries per day is 4 , whereas for firms between 2 and 8 hours away the mean number of deliveries is 2 (modal values 4 and1 respectively).

The data of figure 10, which displays delivery frequency against straight-line distances between plants, leads to a more subtle understanding of the relationship between spatial framework and delivery frequency. A perfect correlation would have led to an inverse linear relationship - the closer, the more frequent -but the pattern observable is less clear. Since these are all new investments we would have interpreted this as showing that firms that needed to make frequent deliveries therefore selected closer locations. First, 11 of the 13 suppliers with the most frequent delivery schedule over 2 deliveries per day - are indeed located within 80 miles / $130 \mathrm{~km}$ (straight line distance : still under two hours) of their customer. Of the two frequent deliverers outside this radius, both are located midway between Marysville and another transplant that accounts for 20 percent and 35 percent respectively of their output, and they may have played off ease of transport against opportunity to supply a second customer.

Second, it is noteworthy that otherwise the top right corner of figure 10 is conspicuously empty; ie frequent deliverers do not locate further than 2 hours from Honda. Within the 80 mile / $130 \mathrm{~km}$ radius, however, the frequency of deliveries is highly variable, suggesting that other factors come into play in determining delivery frequency, such as nature of part supplied (eg size, number of variants, whether part is 
coloured) which determine what form of just-in-time is most suitable, and also implying that more may lie behind selecting locations producting spatial concentration than simply frequency of parts deliveries (see below).

Third, firms which deliver 2 or fewer times per day are more scattered spatially, some within 50 miles / $80 \mathrm{~km}$, others located over 200 miles / $320 \mathrm{~km}$ away. It is not possible to judge whether the need for fewer deliveries allows for greater distance, or, inversely, greater distance resulting form other factors leads to fewer deliveries. As mentionned, some firms report that they have modified their JIT scheduling due to distance.

It is noteworthy, however, that none of these suppliers has located outside the narrow north-south corridor dubbed by some "auto alley" that links the Japanese transplant production structures together from southern Ontario to Tennessee. This means that to the extent firms are distant from Honda, they are closer to another Japanese transplant production structures together from southern Ontario to Tennessee. This means that to the extent firms are distant from Honda, they are closer to another Japanese transplant, which they may supply or hope to supply.

\section{b) Second-tier relations}

While as we saw above 92 per cent of transplant suppliers whose major customer is Honda or a Honda supplier report that they deliver parts to this major customer "justin-time", only 47 percent of them (15 of 32) report that their own major supplier (ie second / third-tier firm) delivers parts and materials just-in-time. One might hypothesize that this difference is due to the larger number of domestic firms involved at second-tier suppliers are indeed domestic firms, the proportion of these that are reported to deliver just-in-time, 44 per cent, is not significantly different from the average.

In fact the frequency of deliveries at second-tier level and below is consistently lower than at first-tier level. Thus one firm that supplies Honda 8 times per day receives its own main deliveries 2 times per day. Another firm that supplies Honda every few minutes receives parts 1-2 times per day and 8 times per day.

It is nevertheless true that difficulties due to domestic suppliers have forced substantial modifications to JIT by supplier transplants (table 10). 


\section{Table 10 : How Honda's transplant suppliers have been obliged to modify JIT with their own suppliers.}

Kanban used in Japan, computerized JIT in USA.

We cannot always count on this system working because America is much larger and many companies don't practice it.

Minimums increased - to allow for full exposure (ie larger inventories to ensure all needed parts available).

American raw material suppliers are undependable on promised delivery dates.

Same as Japan except lead times for U.S. made parts are longer.

Until we can source more components in U.S., we have to maintain a larger than necessary inventory.

Can't practice JIT because US suppliers are too unreliable on delivery.

We use JIT for some vendors and some parts. We currently utilize a large portion of imported parts and JIT is not possible in that area.

Adjusted to compensate for longer lead times required by American suppliers.

Modified due to distance. Longer lead times.

Some inventories must be maintained due to distance of delivery of products and delivery of suppliers.

Problems due to domestic suppliers are prominent in table 10. And there is additional evidence that dealing with domestic firms has caused difficulties in implementing JIT. Thus one transplant supplier finds that very large domestic firms like Dupont simply refuse to deliver small amounts of raw materials at regular intervals according to schedules dictated by the transplant, much to the frustration of Japanese staff.On the other hand, a small domestic firm form Toledo, Ohio that manufactures similar materials was apparently eager to accept JIT schedules to win new orders from this transplant. And Japanese staff clearly prefer to contract with such firms because of what one American manager at a supplier transplant described as the Japanese "fixation" with maintaining zero inventory levels.

In another case, a domestic supplier of plastic parts finds demands on it for JIT deliveries are greatly complicated because it also supplies General Motors, with the risk that both customers will simultaneously change their orders at the last minute. And 
another supplier transplant keeps 6-8 days stock of its domestically supplied raw materials on hand, because lead time for new orders from domestic firms is 3 days and there are frequent quality problems with the materials sent.

Besides such difficulties due to domestic suppliers, the comments in table 10 emphasize the importance of the spatial framework in causing modifications of JIT. (Here causality runs from space to JIT, rather than from JIT to space as at first tier level where location choices were new). When distances are longer, JIT is correspondingly more difficult to operate. It is largely at second-tier level that problems due to distance arise. Indeed difficulties due to domestic firms and to longer distances compound each other. Whereas much of the first tier of the production structure has been purpose-built over the last decade in order to implement a JIT manufacturing system in North America, as we have seen above, the second tier relies much more upon existing domestic suppliers. Thus difficulties with domestic materials suppliers, the longer distances involved in inter-firm relations with domestic manufacturing infrastructure, and importation of parts from Japan, all conspire to make JIT implementation more difficult at second-tier level.

Modifications made to second-tier JIT relations typically involve longer lead times, due both to longer distances and to the slowness of domestic suppliers in responding to changed orders, and holding larger inventories, either to guard against risk of late deliveries or because parts delivered from Japan or from distant domestic suppliers arrive in less frequent but larger lots. There is a natural tendency to overorder parts that must be delivered from Japan, both tomeet unexpected changes in Honda requirements and to ensure against potential problems of quality. Despite the legendary high quality of Japanese parts problems do arise. In one case a batch of parts manufactured months previously and sent from Japan to a Honda supplier in Ohio were too small to fit where required, causing great difficulties for the workers installing them.

\section{Quality control}

Honda operates a system ofmanufacturing and parts delivery where the lot of 60 units guides production planning. Parts are packaged and delivereddd in lots of sixty, or, if large parts, in sets of fractions of 60 eg 2 of 30, 3 of 20, 5 of 12, and so forth. Two benefits of this system are ease of logistical planning and rapidity of accounting for quantities delivered. But a principal advantage is that it provides a highly effective automatic control over both the provider of parts and the manufacturing process at the purchaser at the point where the parts are used. Thus a worker using parts in an 
assembly process who runs out of one part before expected or finds one part left over in a parts cart unexpectedly, is provided with a simple but immediate and effective signal either that the supplier has made an error or that the worker has recently neglected to install a part. Downstream workers can quickly check the latter possibility before too much further production has taken place. (Note also how this system reduces the need for all sorts of indirect workers, in logistics, quality control, accounting).

This kind of system in turn acts as a means of pressure upon the supplier, in a manner parallel to how reduction of inventories is said to provide pressure for other improvements in traditional explanations of JIT. In both cases what is demanded above all is perfect quality of parts supplied; not only an absence of defective parts, but also shipments of the correct quantity. The result of operating the system effectively is extremely high quality of finished products, virtually no wastage of parts, and far less supervision by managers and engineers in logistics and quality control.

The importance Honda attaches to quality of parts is reflected in the response to the discovery that someone has delivered defective parts. NInety-seven percent of transplants in the Honda produc4n structure receive immediate feedback by telephone or cable if a defective part is discovered by people using the parts $(n=32)$. The exception here is an irregular supplier of capital equipment. And 100 percent of the transplants immediately contact their own suppliers by telephone or cable if they find any defective parts.

By the late 1980s the overall parts rejection rate at Honda's Marysville plant was reported as 0.07 per cent ( 7 in 10,000). One supplier transplant had only 0.01 percent of its parts rejected by Honda, which translated into about one per month, although on one new production line the "high" number of 4 parts per month was being returned by Honda (Honda workers would be taking special care to vet these particular parts as they used them, since they would know they were coming from a new source). Honda rejected 0.03 percent of parts fron another firm, while at a third, which was experiencing considerable quality problems with a domestic supplier, the reject rate sometimes reached 0.1 per cent.

While Honda itself audits the quality of incoming parts from its first-tier domestic suppliers, there is no parallel mechanism for what Honda calls "long-established, closely related" firms (ie Japanese transplants). Instead, it is Honda production associates who find defects as they are installing parts. In either case, when problems are reported (ranging from mix-ups of different parts to quantitative mis-shipments and to actually defective parts), Honda engineers telephone the responsible firm immediately : "one little 
thing and we hear about it", according to one transplant supplier manager. According to another, "Honda may understand a scratch, but mis-assembly or paint problems is a big deal". Another supplier company engineer reports that after each incident, there is "no finger pointing, no excuses either", but Honda requires that a full explanation and a plan to prevent recurrence are prepared and signed by managers and filed within a week. Honda not infrequently send its own personnel to suppliers to help resolve apparently systemic problems.

\section{Rapid response to changing orders}

Honda's policy is to plan production schedules well in advance and to adhere to them as a matter of internal discipline. This includes lots of sixty on final assembly lines rather than the Toyota-style line-balancing mixes increasingly adopted by western firms. Nevertheless, managers quite frequently change planned schedules in a manner that requires suppliers to respond very rapidly, perhaps by altering delivery timing or delivery sequences for parts or by altering the balance of different parts required.

This need for rapid alterations to manufacturing by suppliers is premised upon two aspects of the production system Honda uses. First, suppliers stress that when the production schedule is disrupted for any reason, Honda often, as a matter of manufacturing strategy, rejigs its manufacturing schedules at the last moment in order to keep production running, rather than simply halting production for short periods. Short lead times, then, are less of a permanent feature of manufacturing and more of a frequent surprise. Thus Honda may experience a problem of painting, so that working with a particular colour is proving problematic. Or it may be that a supplier of certain parts is experiencing delivery or quality difficulties. Honda then responds by rearranging production schedules in an attempt to keep production running while the difficulty is resolved. The changes requested run from delaying or accelerating delivery schedules through to manufacturing parts of a different colour than had been expected.

A second aspect of the production system that Honda uses which leads to a need for rapid reaction times is precisely the just-in-time parts delivery system. Low just-intime inventory levels imply that withdrawing parts from inventories is not possible as a means for either Honda or suppliers to provide the necessary elasticity.

Transplant suppliers display a varying ability to respond to Honda demands for changes involving altering their manufacturing processes (Table 11). Some firms can respond very quickly, many on the same day and over half within 24 hours. That others respond more slowly may well be because they do not need to frequently alter their 
manufacturing process since they do not produce parts for which Honda demands shortnotice changes. Indeed it is worth stressing the importance of this kind of difference, where the demands placed upon inter-firm practices vary greatly depending upon the part supplied, how it is used, and so on. Not every component is a seat.

\section{Table 11 : Some Honda supplier transplants can very rapidly to changing orders involving revising their manufacturing process, others less so : table shows time from receiving a changed order to arrival of part at customer}

\begin{tabular}{lc} 
Reaction time & Number of suppliers \\
\cline { 2 - 2 } Less than 2 hours & 0 \\
2 to 8 hours & 7 \\
8 to 24 hours & 4 \\
24 to 48 hours & 2 \\
48 hours to 1 week & 4 \\
Over 1 week & 4 \\
\cline { 2 - 2 } & $(\mathrm{n}=21)$
\end{tabular}

Fast reactions are called for throughout the Honda production structure. One supplier transplant engineer with previous experience implementing JIT systems at Chevrolet finds that Honda sometimes only gives his new firm 90 minutes to 2 hours lead time, versus 2 days at Chevrolet. Moreover, it is these short lead times, he argues, that force those suppliers subjected to them to select locations within a maximum of one hour's transit time from Honda, since the travel time becomes a crucial element in response time. By contrast, at Chevrolet location of suppliers was not considered important.

And the better domestic suppliers are set the same stringent targets for last minute changes. Thus one supplier of plastic parts was told by Honda on a Thursday tocompletely alter the sequencing of components it was preparing for Honda to use in assembly the following Monday. Thousands of parts were repackaged, with work continuing all weekend to meet the monday morning deadline. 
Finally, supplier transplants sometimes resort to flying parts in from Japan to the regional airports at Dayton or Columbus in order to meet Honda's changing needs, though the lead time here can be as long as 5 days because 2-3 days are lost at customs facilities in San Francisco.

\section{Reducing prices of parts}

Many contracts between Honda and its suppliers in North America follow the Japanese pattern whereby price reductions are expected during the life of contracts. Thus 75 per cent of supplier transplants whose major customer is Honda are expected to reduce prices during their contacts $(n=20)$. In turn, 75 percent of Honda's supplier transplants expect their own suppliers to reduce prices in similar fashion $(n=32)$. Supplier firm managers report constant pressure to reduce prices, which is justified by Honda with the concept of "learning curves" (ie as manufacture of a part continues over time, the firm should become more adept, make less mistakes, and therefore be able to reduce costs). Neither are domestic suppliers immune from pressure on prices, sometimes complaining that profit margins are lower than they should be.

\section{Moving personnel within the JIT region}

The concentrated network spatial framework of the Honda JIT region enables Honda and suppliers tomove personnel from one plant to another with relative ease. These personnel movements take several forms. First, there are permanent reassignments that, because of proximity between plants, do not require employees tomove house. Thus when Honda first opened the western Ohio Anna meahcnical components plant in 1985, it could draw upon an experienced cadre of managers and production associates already employed at Marysville for permanent reassignment to Anna without them necessarily moving house, especially those whose homes were located between the two plants. Likewise, with the opening of the East Liberty plant only a few miles west of Marysville, the backbone of the new workforce, including many managers and engineers and the core team leaders, could simply be transferred 
from the Marysville plant. In both cases these reassignments accelerated the pace at which the new plants could be brought up to their full capacities.

A second form of personnel movement is the temporary reassignment. This often involves Honda engineers being assigned over a period of several months to other Honda plants or to supplier firms in order to help with introduction of a new product or new process. Alternatively, if a supplier is experiencing particular quality problems it may find Honda engineers from Marysville commuting every day to its plant until the problem is resolved.

A third form of personnel movement is the regular meeting. Here the network spatial framework plays a crucial role, because it allows all sorts of meetings between personnel from different plants to take place regularly with minimal inconvenience. Meetings variously involve Honda, and first - and second-tier suppliers. At one supplier transplant, for instance, the pre-production phase was characterized by meetings at least once per week with Honda engineers to discuss product quality, meetings which sometimes also included second-tier suppliers. Similarly, personnel / human relations managers from the western Ohio supplier transplants hold regular meetings at which they can compare notes on policies and problems. One topic of discussion at these meetings was whether one supplier transplant had been justified in hiring many production associates previously laid off from a local unionized domestic manufacturer which had recently shut down its plant and moved operations to Mexico.

\section{Integration of $R \& D$ into the production structure}

The transfer of research and development activities from Japan to North America on a systemic basis is an especially interesting issue in the case of Honda, which is a particularly product-oriented firm in which the Honda Research and Development subsidiary plays a very prominent role (thus the penultimate rung on the Honda career ladder - just below president of the whole - is invariably presidency of Honda R\&D). Part of the difficulty of transferring research and development activities out of Japan and to the long period that will be necessary to recreate an equal structure in North America even with transfer of a core Japanese staff. But a more significant difficulty concerns the potential role of Honda's supplier transplants. Many of their parent firms are medium and small enterprises, which may be able to support an R\&D staff in Japan, but for 
whom questions of economies of scale make the prospect of a full R\&D facility in North America difficult to contemplate.

Accepting that Honda is intent upon building up its own R\&D activities in North America, if R\&D is to be maintained as a systemic activity - ie involving supplier firms too - Honda faces the prospect of having its own R\&D infrastructure in North America which has to deal with supplier R\&D offices in Japan for collaborative design of parts that will then be manufactured at North American transplants. Needless to say, the spatial separation of North American Honda R\&D from Japan-based supplier R\&D, on the one hand, and of Japan-based supplier R\&D from North American supplier transplant production would cause immense problems. Japanese-style collaborative R\&D activity might well be crippled. Even if not, it would be dramatically slowed, causing Honda to lose one of the competitive advantages it has pioneered in Japan, its ability to keep shortening the concept-to-production lead time for new cars so as to respond rapidly to new customer tastes. In the location of supplier firm $R \& D$, then, we have a key problem for Honda to resolve in meeting its announced goal of designing cars for the North American market in North America.

By the late 1980s Japanese staff at Honda suppliers were talking openly about the possibility of adding R\&D functions to their activities, but several American staff noted pointedly that no concrete moves had yet been made in that direction. Nevertheless, since 1988 considerable progress has been made towards actually achieving a substantial $R \& D$ effort that is integrated into the overall production structure, including Honda's suppliers.

In the first place, Honda's own North American R\&D activities, which had already in the early 1980s included conceptualization of the sporty CRX variant of the Civic model, led in 1990 to the launch of the station wagon / Aerodeck version of the Accord model, into which North American staff (California and Marysville) were reported to have had substantial input. Thus Honda is moving steadily towards its own goal of full North American design capacities (Note, however, that it seems unlikely that the firm will ever seek to design a whole, completely separate - including engine, power train and electronics - car in North america : this simply would not make sense because it is not in this domain that global local marketing strategy requires variation). In particular, the Accord model in now a thoroughly Americanized car in concept, and successors to the current version will surely be increasingly designed in North America.

Secondly, in 1991 Honda announced that it planned to involve North American suppliers to a substantial degree in R\&D activities destined for the next (1993). Accord 
model, responsibility for the design and development of which, it appears, is indeed being gradually shifted from Japan to North America. Honda is certainly moving this way itself, with establishment of a supplier transplant in suburban Columbus Ohio that manufactures full scale design models for Honda. This firm may become part of a coordinating structure for R\&D activities by supplier transplants.

\section{Honda Engineering and supplier firms}

While the subsidiary firm Honda Engineering is itself responsible for design and manufacture of much of Honda's capital equipment, the honda Engineering branch located at Marysville has developed purchasing arrangements with several supplier transplants and domestic firms that manufacture capital equipment, for instance suppliers of flexible manufacturing systems, moulds for plastic injection moulding machines, chrome plating of steel stamping dies, and manufacturers and repairers of robot welding heads. A group of such firms is located in the southwest quadrant of Ohio in and around Cincinnati and Dayton, traditional midwestern engineering cities and within short drives of Marysville. This area is at the geographical heart of the corridor of japanese automobile industry transplant investments, and is ideally located for capital equipment manufacturers to establish bases from which to service all the transplant firms. In some cases Japanese capital equipment makers have purchased existing domestic firms, in other cases they have established plants close to the sources of skilled engineering labour that they require for capital equipment manufacture.

\section{Interventions into other firms}

Under a JIT inventory control system, manufacturing difficulties experienced at Honda or at its suppliers ara rapidly transmitted to the rest of the production structure, potentially halting production at many plants simultaneously. Clearly it is therefore incumbent upon each factory in the system to ensure that all machinery functions properly, that no labour relations problems interfere with production, and that high quality parts are delivered on schedule. this mutual interest - highly intensified by the JIT system with its small inventories - explains much of the extraordinary concern that Honda and its suppliers maintain in each others' "internal" operations.

Whereas in the traditional North American model of relations between assembly and supplier firms in the automobile industry, the internal functioning of partner plants 
was considered a private affair, within the Honda production structure related firms seek to learn as much as possible about relevant parts of each others' operations. One aspect of this is that supplier firm engineers and production associates alike visit Honda in large groups, especially to learn about the downstream process whereby "their part" is installed in vehicles or is otherwise used.

More importantly, Honda and its supplier transplants not only learn about but actively intervene in the "internal" activities of their upstream suppliers (Table 12).

Table 12 : Honda intervenes to observe and advise in the some but not all "internal" activities of its supplier transplants

When the transplant was

Does Honda intervene?

setting up operations :

Quality control methods

Production methods

Labour recruiting / training

Yes No No answer

With full production

under way:

Quality control methods

Production methods

Labour recruiting / training

$\begin{array}{rrr}16 & 1 & 4 \\ 11 & 6 & 4 \\ 4 & 13 & 4\end{array}$

$\begin{array}{rrrr}15 & 0 & 6 \\ 11 & 4 & & 6 \\ 2 & 13 & & 6 \\ & & & \\ & & & \\ & & \end{array}$

The more directly connected to Honda's own manufacturing is the activity in question, the higher is the level of intervention. As far as quality control methods are concerned, such interventions are the norm, and they also occur frequently regarding manufacturing techniques used. By contrast labour recruiting and training are not considered to be a proper area for intervention.

While earlier we mentionned that Honda does not separately inspect parts it receives from transplant suppliers, Honda by no means treats its supplier transplants as privileged group free of all outside intervention. Indeed transplant managers and engineers report that they feel themselves to be under constant pressure from Honda. One new supplier transplant had received two quality ratings from Honda even before trial production had started. When a new product line for Honda was being introduced at one supplier transplant, Honda engineers "practically lived here", according to an American manager. With production successfully under way, however, Honda "backed off". Nevertheless, the high rates of Honda intervention - even with full production 
under way (Table 12) - underlines just how crucial is the role of the supplier chain from Honda's perspective.

Moreover, Honda's supplier transplants behave in just the same way with their own suppliers. The pattern is repeated : higher intervention rates in quality control, somewhat less in production, and little intervention in labour recruiting and training (Table 13).

Table 13 : Honda supplier transplants intervene to observe and advise in some but not all of the "internal" activities of their suppliers

\begin{tabular}{lccc}
\hline & \multicolumn{2}{c}{ Do you intervene } & \\
\cline { 2 - 3 } & Yes & No & Answer \\
& 25 & 1 & 6 \\
Quality control methods & 21 & 5 & 6 \\
Production methods & 2 & 24 & \\
Labour recruiting / training & & & $\mathrm{n}=32$ \\
& & & \\
\hline
\end{tabular}

Noteworthy is the higher intervention rate at second-tier level regarding production methods and the slightly lower intervention rate regarding labour recruiting and training, in comparison with Honda's interventions in its supplier transplants. This difference is hardly surprising because, unlike the first-tier transplants, most of these second-tier firms are domestic manufacturers for whom just-in-time production systems are novel, but which have long established labour forces. Interventions in domestic firm activities will be discussed more fully below.

Japanese staff at supplier transplants are said by their American colleagues to be extremely demanding of potential second-tier suppliers, appraising in detail all aspects of each firm's operations. Honda participates itself in some cases, joining supplier engineers in inspection visits of second-tier suppliers. Indeed Honda Engineering approval is often needed for second-tier parts purchasing, even of the smallest nuts and bolts.

\section{Reorganizing the inter-firm division of labour}

Several transplant suppliers, as we have seen, manufacture multiple related and sometimes unrelated products within the same factory. This organizational framawork 
was encouraged by Honda especially during the early years of production, when Honda output stood at only 150,000 cars per year instead of the 600,000 attained by the early 1990s, and Nissan was the only other transplant producer in the eastern United States. Thus different Japanese firms would join forces in a JV under one roof as a means to reap economies of scale.

In some cases Honda took the direct initiative of organizing its own supplier firms, in particular two multiple product Bellemar Parts plants, in which Honda held an 80 percent stake, with two Japanese suppliers taking 10 percent each. Bellemar Parts Marysville opened in 1982 when Honda assembly began, manufacturing seats and wheel-tyre combinations. Bellemar Parts Russells Point opened in 1985, after the initial problems with domestic suppliers had become evident, to manufacture seat frames, brake lines, catalytic converters, door sashes and exhaust systems. In other cases Honda encouraged JVs, for instance, one among four of its Japanese metal stamping / welding firms which joined together in a four-way joint venture, KTH, opened 1985, to make fuel tanks, wheel housings and interior metal walls eg between cabin and engine compartment. In each case considerable economies of scale could be realized by sharing overhead costs.

One result of the diminution of the economies of scale problem that has accompanied increased outputs is the shifting pattern of joint venture arrangements, away from Japanese-Japanese cooperation, that we noted above. A second, related result, has been a significant evolution in the inter-firm division of labour. This reflect necessary and possible shifts in supplier firm activities that have accompanied a restructuring of the organizational framework of the production structure from one appropriate to an initial production capacity of 150,000 cars per year to one appropriate to four times this capacity.

Hence the inter-firm division of labour has gradually deepened. Indeed Honda's earliest supplier transplants have undergone significant evolutions in products manufactured since the early 1980s (see table 14).

\section{Table 14 : Late 1980s deepening of the inter-firm division of labour at early-established supplier transplants}

- 1987 : shift of brake line production out of Bellemar Parts Russells Point factory to new specialist Japanese-US joint venture Hisan (Findlay, Ohio, 40 miles / $65 \mathrm{~km}$ away). 
- 1989 : shift of sourcing for alliston seats from Bellemar Parts Marysville, which had built 3rd production line for this purpose, to new Bellemar factory in Canada : line at Marysville then switches to supply newly opened East Liberty assembly plant (n.b. coincident opening of East Liberty and Bellemar Canada).

- 1989 : shift of some stamping and welding production (together with capital equipment) out of KTH (St. Paris Ohio), four-way Japanese joint venture transplant established in 1985, to Jefferson Industries (Jefferson, Ohio, 45 miles / $70 \mathrm{~km}$ away), 3-way joint venture established by two of the KTH partners and Honda (30\%) in 1989.

- 1989 : Yutaka Giken, Honda's largest provider of large stampings in Japan, builds new metal stamping facility for torque converters and oil pans adjacent to Bellemar Parts Russels Point factory. Yutaka Giken takes 10 percent share of Bellemar Parts, Honda increases its share from 80 to 87 percent, other Japanese partners reduced from 10 to 1.5 percent each.

- 1989 : Sankei Giken, one of the Bellemar Parts owners reduced from 10 to 1.5 percent, opens Blanchester FCM in southwest Ohio, tomake power steering systems for Honda. Tokyo Seat, the other Bellemar partner reduced from 10 to 1.5 percent, has in the meantime built several of its own factories in North America, making seats and seat parts for Honda and for other assemblers.

This ability of the production structure's organizational framework to evolve new divisions of labour indicates what a flexible production structure has been created, in which the firms involved are retained even as they change their roles and as the components required from them are changed. This process closely resembles the "spinning off" of separate companies which characterizes accounts of the growth of the Japanese automobile industry in the 1950s and 1960s. Also noteworthy is the shifting pattern of financial holdings as interests in different firms change over time, as well as the rapidity of these organizational restructurings, occuring only 2-7 years after initial production had commenced.

The spatial framework of the Honda JIT region that we have characterized as a concentrated network form plays an important role in permitting these kinds of restructurings of divisions of labour. That many firms are located within a relatively short distance of each other permits flexibility in determining future arrangements.

\section{Dealing with domestic suppliers}

We have already discussed in passing many aspects of inter-firm practices that involve domestic suppliers to honda, showing the roles which these firms tend to play in the Honda production structure, and alluding especially to some of the difficulties that 
Honda and supplier transplants have experienced in implementing JIT relations with domestic firms.

Relationships with domestic firms embedded in the Honda production structure are worth looking at more closely, for two reasons. First, these relationships have played a significant role in explaining Honda's parts sourcing practices, since relations with domestic firms during the early 198às formed the context for development of decisions during the crucial late 1980s over whether Honda would source parts from Japan, from domestic firms, or from supplier transplants. Second, these relations are of enormous broader significance since they hold one of the keys not only to the ability of Japanese firms to transplant their production structures abroad, but also to the much wider diffusion of Japanese inter-firm practices, and of Japanese manufacturing processes in general, into the industrial infrastructure of North America.

Prior to start-up of the first production at Marysville in late 1982 Honda searched for domestic suppliers by giving a set of domestic firms carefully selected in advance plans for manufacturing of the Accord. Presumably this selection was meant to indicate to these firms that they stood a very good chance of gaining Honda contracts. However, whereas in Japan supplier firms are expected tomaintain secrecy even when they deal with several assemblers at once, some of the domestic firms appear to have circulated Honda's plans within the wider domestic automobile industry, leading to their publication in the United States automotive press. Honda viewed this as a betrayal of confidence, concluding not only that it could not trust domestic firms but that domestic supplier firms did not trust the automobile manufacturers.

Moreover, this inauspicious start was soon aggravated when many suppliers that were contracted simply did not take seriously Honda's strict demands for parts quality and delivery scheduling, tending to treat them with a "flexibility" that Honda did not expect. The problem, according to a Japanese Honda manager who has been in the United States from the start of Honda production there, was that domestic firms claim thay they understand total quality control and just-in-time techniques, but in reality are unable tu fulfil their promises. American managers at transplant suppliers agreed with this viewpoint, regarding domestic suppliers as superficial in their understanding of JIT. according to one, neither are they able to meet the short-notice changes that are expected:

Japanese firms are more adaptive, US firms can't handle rapid changes in what's demanded of them (Personal interview, 1988).

The result was that of the original set of domestic firms selected for 1982 production, less than 30 percent were retained by the late 1980s, the rest having been discarded because of problems related to quality, delivery or confidentiality. 
After these early setbacks Honda developed a fresh approach to dealing with domestic firms, which has guided it since the mid 1980s. Rather than contracting with domestic firms in a more or less typical North American manner (in terms of organizational framework), and expecting the domestic firms to learn and to implement Japanese-style inter-firm practices, Honda seeks to create exclusive, long-term relations with domestic suppliers wherever possible, and is prepared to invest a determined organizational effort if this is necessary to bring suppliers up to expected standards regarding the inter-firm practices that we have been discussing above.

Both these organizational framework aspects - exclusivity and long-term relations- however, have considerably constrained Honda's ability to widen its network of domestic suppliers in North America. Not only is there a limited number of automotive suppliers that are independent - not vertically integrated into Big Three firmsbut to gain truly exclusive relations Honda has pursued contacts with firms previously outside the automobile industry, such as a manufacturer of children's toys that now makes tubular plastic parts, a lawn-seed testing firm that now assembles radio-cassette loudspeakers, or an alluminium casting firm which does have other customers, but all outside the automotive industry.

In this fashion Honda has been effectively developing what amounts to a parallel automobile industry rather than rooting itself in the traditional North American automotive supplier base. Not surprisingly this strategy has caused consternation in the domestic automotive supplier industry and its representatives (see Mair, 1991).

Honda is also constrained in an organizational sense when it is obliged to offer the services of its engineers to aid domestic firms, taking the risk that any problems encountered will not easily be resolved, thus threatening tightly planned production schedules in the assembly plants as the new supplier is brought on line and up to speed. On several occasions Honda's Japanese suppliers have been drafted in to aid new domestic suppliers, and domestic firms have beeb obliged by Honda to buy Japanese capital equipment.

The end result is that domestic firms have found gaining contracts with Honda to be particularly difficult because of the changes Honda puts them through compared to their traditional methods of manufacturing, quality control, and delivery scheduling. Essentially, Honda has refrained from simply drawing up contracts with given suppliers to supply parts and then leaving the supplier to fend for itself in typical traditional North 
American fashion : this organizational framework does not provide the results Honda requires. Instead, many domestic firms have found their whole internal structures - from production techniques to organizational frameworks - gutted and rebuilt : either they have done it for themselves or Honda has done it for them.

Honda's American Vice-President for Purchasing is one of the few American Honda managers with previous automotive industry experience, having worked for the large domestic manufacturer TRW as world-wide purchasing director. He was "flabbergasted" by Honda's quality requirements :

We expect basically zero defects. Our goal is to have four hours of inventory.

They think we're quoting from textbooks... It is with great difficulty in almost

every instance that we localize parts with an American source (Nelson, in

Electronic Business 1988 : c/f Nelson's five principles).

By the end of the 1980s finding domestic suppliers was becoming progressively more difficult. According to one Honda manager, the firm had virtually finished sourcing "big, easy parts" in North America, and was now contemplating the small, complex components still sourced from Japan, for which finding domestic suppliers might prove very difficult indeed. It was at this stage that Honda began to enter into a significant number of purchasing arrangements with joint-venture suppliers being set up in North America by some of the larger independent domestic suppliers, firms like TRW, DANA, Johnson Controls, in alliance with significant Japanese firms.

Examination of cases od domestic firms with which Honda has contracted purchasing arrangements is very instructive in giving a fuller picture of these relationships. Two lessons emerge consistently from these relationships. Two lessons emerge consistently from these analyses, whether they are success stories or are failures. The first is the enormous gap between visions among American versus Japanese managers on correct practices of business management - internally and in inter-firm relations - and of production organization. The second is the high level of pressure either active intervention or telling the firms to come back with "something really new to offer" - by Japanese firms in the internal affairs of the domestic companies in order to force their particular visions onto the domestic managers. One of the important conclusions to be drawn here is that even if Honda has been prepared to alter to some extent its organizational and spatial frameworks - perhaps for the better - to meet local North American conditions, it has not been prepared to dilute its Japan-developed manufacturing techniques and inter-firm practices. It is therefore insisting on transplanting its model of inter-firm practices fully or not at all, refusing to transform its practices to meet existing local conditions. 


\section{Appendix 5}

Related news articles and website reference articles. 


\title{
$\underline{\text { Honda Project Reference Articles }}$
}

\author{
Background information on Greensburg: \\ From http://en.wikipedia.org/wiki/Greensburg,_Indiana on June 18, 2007 \\ Population;10,260 (97.57\% White) \\ Median Income for Household: \$38,029 \\ Per Capita Income: \$18,829 \\ $11.4 \%$ of population below poverty line \\ Greensburg Daily News, Owned by Community Newspaper Holding, Inc.
}

Greensburg Transportation Greensburg is located adjacent to Interstate 74, halfway between Indianapolis and Cincinnati.

U.S. Highway 421 links Greensburg with Indianapolis to the north and Lexington, Kentucky, to the south. State Road 3 connects Greensburg with Muncie and Fort Wayne to the north and the Indiana suburbs of Louisville, Kentucky, to the south. State Road 46 links the community with Columbus, Bloomington, and Terre Haute to the west and Batesville to the east.

Greensburg is a likely train stop on the proposed high-speed rail line between Indianapolis and Cincinnati. This line is part of the Midwest Regional Rail Initiative, which is the master plan for a high-speed rail network throughout the midwestern United States.

The Greensburg-Decatur County Airport consists of a single runway measuring $3343 \mathrm{ft}$. by $40 \mathrm{ft}$. There are tentative plans to either expand the current runway or build a new airport elsewhere in Decatur County.

Indianapolis International Airport is located 55 miles from Greensburg, and Cincinnati Northern Kentucky International Airport is located 70 miles away. 
Honda Mfg. Plants in Ohio: Russels Point (Transmission mfg.), East Liberty Automobile Plant, Anna Engine Plant, Marysville Automobile Plant, Marysville Motorcycle Plant.

Total Estimated Distance of each Ohio Plant from Greensburg:

Russels Point- 166.69 miles

East Liberty- 163.33 miles

Anna- 148.00 miles

Marysville- 164.24 miles

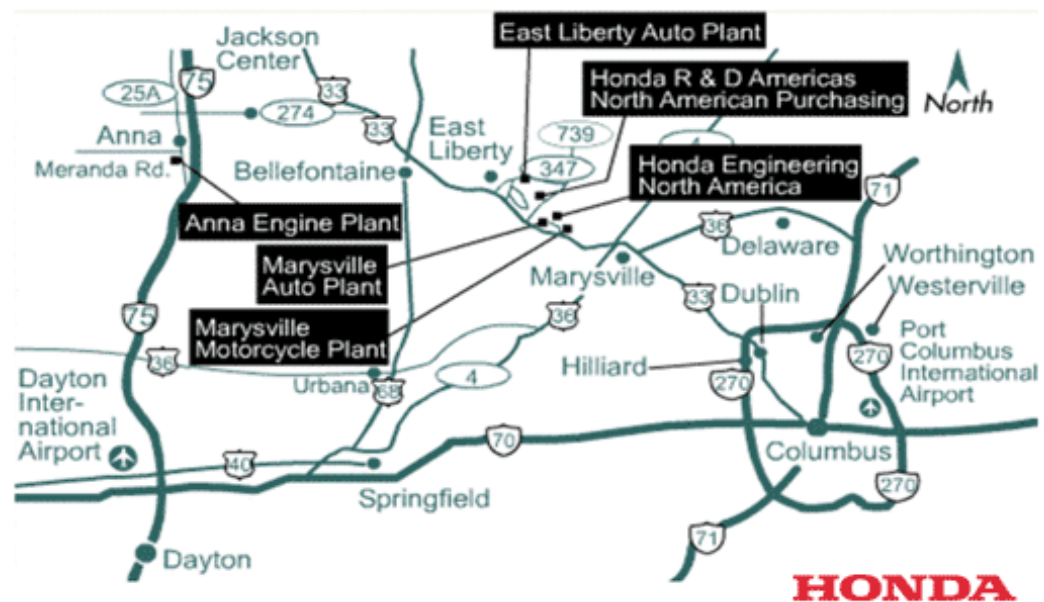

http://ohio.honda.com/print/index.cfm?section=CMfg on J une 19, 2007

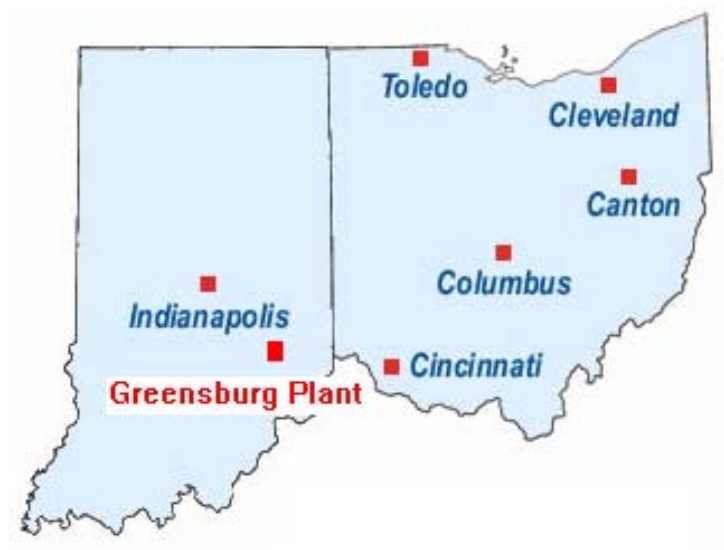


By Jim Stinson, Merrillville Post-Tribune staff writer (6/29/2006) From

http://www.indianaeconomicdigest.net/main.asp?SectionID=31\&subsectionID=64\&articleID=27829 on

June 19, 2007

\section{\$550 million Honda plant likely to reach Northwest Indiana region}

While not directly employing people from the region - unless they move or commute to downstate Greensburg - the new American Honda Motor Co. plant will benefit the whole state, officials said. In fact, Northwest Indiana businesses already are expecting orders from the automobile assembly plant. Indeed, whether Honda had built in Ohio or Illinois, Mittal Steel USA was sure to be asked to supply materials.

"We supply virtually every automaker in the United States," said David C. Allen, communications manager for Mittal. "We have done business with Honda ever since they came here." With Honda's announcement Wednesday that it will build a plant in Greensburg, some business and state officials expect statewide benefits. But most of the immediate economic benefits will go to central Indiana, already home of a foreign-car company's plant.

So why didn't Honda think about Northwest Indiana? Honda chose the location based on proximity to suppliers, according to David lida, Honda spokesman. "We already have 46 suppliers in Indiana," said lida, adding the majority of those suppliers are in central and eastern Indiana.

Larry Jutte, senior vice president of Honda of America Manufacturing Inc., would not divulge to reporters the names of other areas considered. He said the Greensburg site was close enough to suppliers to be chosen, but not too close, indicating Honda did not want to disrupt employment at its supply companies or its own Ohio plants in Marysville and East Liberty. Another factor in location may have been labor. Northwest Indiana has no automotive plants, and some speculate union activity here steers foreign automobile companies away from the region. Honda associates historically have not sought to organize, lida said, and Honda's American plants are not unionized.

In north-central Indiana area, the nonunion factor may have helped land the automobile factory run by Subaru of America Inc., Smith said. The Tippecanoe County plant broke ground in 1987, and recently announced a subcontracting deal with Toyota Motor Corp. to build the Toyota Camry model. The Japanese-owned plant, which employs 2,400 people, is nonunion, Smith said.

Smith said the Honda plant will create economic spin-offs and opportunities all around Indiana. Honda will build the $\$ 550$ million auto assembly plant as part of a $\$ 1.18$ billion global expansion, company officials said Wednesday, ending a five-state scramble and bringing jobs to a state hit hard by manufacturing losses. The factory will employ 2,000 nonunion workers and eventually produce 200,000 vehicles annually, officials said.

The Japanese automaker announced in May that it planned to build its sixth North American plant in the Midwest, but did not say where. Officials from Ohio, Indiana, Michigan, Illinois and Wisconsin promoted sites in their states. "We believe that the great state of Indiana has what we need to continue ... success: an outstanding community of people, excellent transportation systems and the necessary infrastructure to support industry," said Koichi Kondo, president of American Honda Motor Co. Gov. Mitch Daniels, who returned to Indiana early after a trip to Asia, welcomed Honda officials. "Honda is going to feel right at home in Indiana, and you are going to love Greensburg and this part of our state," Daniels said.

The Honda plant will help invigorate the state's economy, which has lost 98,000 industrial jobs since 2000. Construction will be completed in 2008. Kondo declined to say which vehicles would be produced, although the cars would be four-cylinder models. An Ohio plant will provide the engines, Honda said. Honda and its larger Japanese rival, Toyota Motor Corp., have been increasing their North 
American manufacturing capacity to keep up with demand, even as U.S. automakers General Motors Corp. and Ford Motor Co. are cutting thousands of jobs and closing plants as their market share declines. North America accounts for about half Honda's annual global sales. 
7/8/2006, Mike George and Annie Goeller, Daily Journal of Johnson County from http://www.indianaeconomicdigest.net/main.asp?Search=1\&ArticleID=27957\&SectionID=31\&Sub SectionID=194\&S=1

\section{Honda's ripple effect could impact three of Johnson County's largest plants}

Three of Johnson County's largest employers are playing a waiting game.

KYB Manufacturing North America Inc., NSK Corp. and Casting Technology Co. build parts, either directly or indirectly, for Honda. But company officials don't know how plans for a new Honda plant in Greensburg will affect them.

Honda hasn't revealed what types of vehicles will be built in Decatur County. Rumors are circulating that the Honda Civic or Fit will be built there. Honda plans to tell suppliers soon, spokesman Ed Miller said.

Combined, the three companies employ more than 1,000 people.

KYB Manufacturing, located along U.S. 31 in Franklin, builds shock absorbers and struts for the Honda Civic, said president David Billingsley.

Honda is its second largest customer, behind Toyota. The company recently opened a 180,000-squarefoot warehouse at the old Arvin plant in Franklin. Plans are under way to expand the plant's production by 10 percent. The plant has 650 employees, with another 40 temporary workers. "The new plant may create some additional business for us, but I can't say if we'd have to hire more people," he said. "You have to understand they aren't opening until 2008." "Right now, they're building the Civic in Ohio and Canada," he said. "If they build in Greensburg, they're going to cut down on their own transportation costs in shipping our parts." KYB has been supplying parts to Honda for 10 years.

NSK Corp., a global company with 250 employees at its plant in Franklin, makes wheel bearings for the Honda Civic and Accord, as well as the Odyssey minivan and Pilot sport utility vehicle. The company also supplies to Toyota, Chrysler, Subaru and General Motors, said human resources manager Jim McGinnis.

Casting Technology Co. is also based in Franklin and has 100 employees. It has been an indirect supplier of air conditioning compressor parts for Honda for 12 years. It sells parts to a company that works directly with Honda.

Chief executive officer Craig Conaty said, "It's way too early to speculate how this will affect us. But what's good for Honda, what's good for the state are typically good for the companies in the supply chain."

All three companies are unwilling to reveal exactly how much money they make from Honda. But all three plan to stay in Johnson County if they need to expand once the Greensburg plant is built. 
6/29/2006 By Eric North, Daily Reporter senior staff writer from

http://www.indianaeconomicdigest.net/main.asp?SectionID=31\&subsectionID=64\&articleID=27824

\section{Greenfield plant getting information about what's to be assembled at new Honda plant}

A new Honda plant in Greensburg that will build 200,000 cars a year may not have an immediate effect on the company's suppliers in Hancock County, but it certainly won't hurt. "We are still getting information on what will be assembled at the plant," said Greg Young of Keihin Indiana Precision Technology Inc. in Greenfield.

The county's largest employer makes fuel injection and engine management systems for the Japanese automaker, so Young is hoping that the new facility will be continuing good news for his plant and the entire region.

"We are still learning more about the plant and what will be built at the plant, but it gives us more opportunities and will keep our main customer's manufacturing close," Young said.

Keihin's Aircon operation in Muncie produces air conditioning parts that are installed directly on Hondas so the new plant would be very good news for the company, according to Young.

"Parts from the plant in Muncie goes directly into the auto assembly business, so this gives them more opportunities to sell to Honda," Young said. Most of the assemblies shipped from the Greenfield Keihin facility go to a Honda engine plant in Ohio, so the local product will not go directly into the new operation. Young said, however, that the location means more chances to pitch Keihin products to its biggest customer. 
8/28/2006 from http://www.greensburgdailynews.com/honda/local story 051102914.html, viewed on June 19, 2007

\section{Indiana, Ohio Try to Lure Suppliers for Honda Plant}

Economic development officials in Indiana and Ohio who competed for a $\$ 550$ million auto assembly plant that Honda Motor $\mathrm{Co}$. announced in June would be built in southeastern Indiana are now engaged in another battle. The two states are vying to attract auto suppliers that would make parts for the Greensburg plant, which will employ 2,000 workers and eventually produce 200,000 vehicles annually. Honda plans to spend $\$ 1.5$ billion each year to provide resources to that plant.

Indiana Commerce Secretary Mickey Maurer said he and Gov. Mitch Daniels are eager for Indiana to beat out Ohio in this next round of Honda-related growth. "We're going to be very aggressive," Maurer told The Indianapolis Star for a Sunday story. Ohio has been Honda's U.S. manufacturing home since 1982 , and it now operates an 11,000-worker car-making hub in west-central Ohio.

A group of 150 Honda suppliers employ 41,000 in Ohio - 20,000 of them dedicated to Honda parts. Nationwide, there are 525 companies in Honda's supply chain, and Indiana has 40 of those.

Economic incentives by state and local governments could play a larger role than usual in deciding which companies will supply Honda's Greensburg plant because potential suppliers could be just over the Indiana state line in Ohio and still be close enough to the plant. Greensburg, located about 50 miles southeast of Indianapolis, is just 40 miles from the Ohio state line on Interstate $\mathbf{7 4}$. And, because most Honda suppliers in Ohio are in that state's western half, many could serve the plant in Greensburg without moving at all.

The fight over suppliers began last month when Ohio announced zero-percent loans for any auto supplier that expands. The program isn't limited to Honda suppliers, but Honda's new plant prompted the program, said Ohio Lt. Gov. Bruce Johnson. Ohio also held briefings for Honda suppliers, offering the help of multiple state agencies to pull off quick expansions.

But Indiana is fighting back. Hoosier officials are pitching Indiana as an ideal place for suppliers to locate if they want to serve Indiana's multiple Japanese auto companies - Honda's Greensburg plant, the Toyota plant near Evansville and the Subaru-Toyota plant in Lafayette.

State officials have also talked with Honda and its rival, Toyota Motor Corp. - which will add 1,000 jobs next year to make sedans at Subaru of Indiana Automotive in Lafayette - to identify suppliers they would most like to have near their factories. "We've got 10 that are looking directly at Indiana versus Ohio," said Nate Feltman, executive vice president at the Indiana Economic Development Corp.

Jody Fledderman, president of Batesville Tool \& Die, expects his proximity to the Greensburg plant to bring him new business. He said his company, which makes various metal parts for Honda, has already had two visits from Honda officials since Indiana won the new plant. "We'll have an advantage because we're only 15 miles away," Fledderman said. 
3/10/2007 Paul Hines, New Castle Courier-Times Staff Writer, from

http://www.indianaeconomicdigest.net/main.asp?SectionID=31\&subsectionID=70\&articleID=32679

\section{Honda supplier makes it official: Building \$32 million plant in New Castle}

Executives from Honda supplier TS Tech made it official Friday - ground will be broken on a new factory in April. By March 2009, the company will employ 300 people to produce seats for the Greensburg plant. Japan-based TS Tech plans to make \$32 million in capital investments and build a 200,000 square-foot factory. Production will start in August. Eventually, it will produce about 800 seats per day for Honda. New Castle and Henry County provided incentives. The state of Indiana also announced Friday it would sweeten the incentive pot adding up to \$2.4 million in tax credits and $\$ 645,000$ in grants to bring TS Tech to Indiana. TS Tech President North America Kazuhisa Saito said the company picked New Castle because it was close to Interstate-70 and close to the Honda plant in Greensburg. 


\section{Honda to Build Plant in Indiana but Ohio Will Supply its Parts}

01st June 2007 from http://www.articlealley.com/article_168717_31.html

Author: Ally Wahlberg

John Miles, General Manager of Florida Production Engineering's Ohio plants has witnessed how Indiana and Ohio competed for Honda's new assembly plant. But he knew that they would surmount whatever trials that will come to the plant. It is no secret that FPE has auto parts manufacturing plant in Circleville, south of Columbus, and in the Darke County Village of New Madison, which is 16 miles from the Ohio-Indiana border. This is also one of the reasons why Miles is confident.

The announcement made by Honda last June that it would build the $\$ 400$ million plant in Greensburg has somewhat disappointed many in the Buckeye State. Despite what happen the Ohio auto parts suppliers have console themselves that Honda with its six North American assembly operations is still near.

Ohio has by far the largest number of parts suppliers to Honda's North American operations. According to Honda spokesman Edward Miller, Ohio has 140 Honda suppliers, which is well above the 74 suppliers in Michigan and its 53 suppliers each in Indiana and Kentucky. Last 2006, Honda has paid Ohio suppliers with $\$ 6.4$ billion which is a big bite off the $\$ 17.6$ billion that the company paid for suppliers nationally added Miller. In North America, Honda has a total of 610 suppliers that provide them with auto components such as Honda hood and auto accessories that are used by the automaker in their auto making business. More than 500 Honda suppliers are found in United States scattered in and around central and western Ohio. 


\title{
3/24/2007 in Daily Journal of Johnson County By ANNIE GOELLER, Daily Journal of Johnson County staff writer
}

\section{Is a job boom on the way for Johnson County?}

At least three companies are considering Johnson County as a place to either build a new business or move into a vacant building, possibly bringing hundreds of jobs.

\begin{abstract}
Since January, the development corporation has gotten about 60 calls and e-mails from businesses or consultants for companies seeking more information about the area, said Cheryl Morphew, executive director of the corporation.

For about 30 of those, Johnson County met the specifications of the company, such as available land and infrastructure, she said. Franklin Mayor Brenda Jones-Matthews said that in the past week she has sent letters to two interested manufacturing companies that want to know more about the city and any possible incentives for locating there.
\end{abstract}

When businesses request those letters, it usually means that Johnson County is a finalist in their search, Morphew said.

With construction started on a new Honda plant less than 40 miles away in Decatur County, local officials said there isn't a rush on advertising Johnson County, but there are added opportunities. Johnson County will be included in a regional map with 10 other central Indiana counties put out by the Indy Partnership with the hopes of recruiting Honda suppliers, Morphew said.

Morphew would not say how many companies currently consider Johnson County as a finalist because many businesses seek confidentiality in the process, she said. In most cases, when Jones-Matthews sends a letter to a business, she doesn't know the identity of the company and is addressing her letter to a code name or number, she said.

Rumors have been circulating that the tire manufacturer Michelin USA was interested in locating in the county. Morphew and Jones-Matthews said they have had no contact with the company, and a Michelin spokesman denied the rumors.

David Neuman, director of the Decatur County area plan commission, said he heard that Michelin decided to go to Franklin after meeting resistance in his area. He wouldn't say who gave him the information but said it was someone who works with Michelin.

Morphew and Jones-Matthews said they didn't know of any Honda suppliers interested in coming to Johnson County. Both attended the groundbreaking ceremony at the Honda plant this week, where they met state and company officials, Jones-Matthews said.

The city should promote the fact that several sites are ready for a company to build on and Franklin has offered incentives to companies in the past, she said. As for new businesses, she plans to work with the Indy Partnership, a nonprofit organization that focuses on bringing economic development to central Indiana, and to keep the development corporation's Web site up to date.

She doesn't plan to advertise or send out mailings to potential Honda suppliers at this point, she said. Advertising is expensive, and the corporation doesn't have the money for it, she said. And seeking out Honda suppliers also is difficult because there is no master list, she said. 
From http://www.rttnews.com/sp/breakingnews.asp?date=06/18/2007\&item=119 on June 19, 2007

--No Relevance to Honda Plant Yet--

Chrysler Group Signs J oint Venture Transmission Plant With GETRAG And Indiana Governor Daniels For Tipton County [DCX]

6/18/2007 6: 03: 32 PM Chrysler Group (DCX) said that it has signed a joint venture with GETRAG and Indiana Governor Mitch Daniels to officially name Tipton County, Ind., as the site of a new dual-clutch transmission of Powertrain manufacturing plant. The $\$ 530$ million investment is another step in Chrysler Group's "Powertrain Offensive" - \$3 billion in investments to produce more fuel- efficient engines, transmissions and axles for Chrysler Group.

Chrysler Group said that it would join with GETRAG executives and Governor Mitch Daniels to celebrate site selection and investment in new plant.

Chrysler Group revealed that, GETRAG would have the operational leadership of the plant which will employ approximately 1,050 full-time Chrysler Group UAW-represented workers and 120 management employees from both companies.

Chrysler Group stated that the construction of 804 thousand square-foot facility is scheduled to begin J une 27, and the manufacturing would start from the beginning of 2009. 
6/29/2006 from

http://www.indianaeconomicdigest.net/main.asp?SectionID=31\&subsectionID=70\&articlelD=278

15

Officials in Jackson, Jennings and Shelby counties eye opportunities

\section{(Columbus) The Republic}

By Brian Sanders, The Republic Reporter

Community and economic leaders in Jackson, J ennings and Shelby counties agree that these areas will mostly benefit from the recently announced Honda plant in Greensburg. "This is great news," said J im Plump, executive director of Lackson County Industrial Development Corp. "This project probably will be the largest or one of the largest announcements in the U.S."

Hall guessed the plant would supply jobs for southern Indiana workers within a 40-mile radius. The mayor pointed at Princeton's Toyota plant, which opened in 1996. About 15 percent of Toyota's employees commute from Kentucky or Illinois, he said.

Plump believes it will take a few years to determine the plant's impact on J ackson County's work force. However, Plump said the Greensburg plant's effect on Jackson County is unpredictable.

"These are going to be great jobs," said Hall. Furgeson's only concern is that Honda's high wages will lure trained employees from Shelbyville industries.

\section{Ripple effect}

Hall believes the Honda plant could lead to several spin-off industries in southern Indiana.

Greensburg's Honda plant is good news for Jackson County companies that cater to the automaker with parts, said Plump.

Honda's supply network in Ohio could expand to meet demand from the new Greensburg plant. Expansions, which will create more jobs, will likely occur in Ohio or southern Indiana.

"This can do nothing but help the entire region," said Plump. The announcement could attract other large companies to southern Indiana. "If Honda selected this area there must be something good going on in the area," said Plump.

Furgeson believes his city of 18,000 people is conveniently located between Indianapolis and Greensburg.

The mayor believes Shelbyville will attract prospective Honda employees, adding to already increasing home construction in Shelby County. One thousand lots are set aside for new homes. 


\section{Honda Information Line}

From http://www.greensburgchamber.com/news.asp?ID=4 on J une 20, 2007

On Wednesday, February 21st, Honda announced their first round of hiring for 18 nonproduction positions which were posted on their website www.indiana.honda.com . Due to the overwhelming response of more than 5,000 applications, they have temporarily stopped accepting applications. Please check their website regularly for updated information. Honda is not yet recruiting or advertising for any production openings.

Honda also has created a phone line to provide basic information and updates about employment, contractor and supplier opportunities at the new plant. The toll-free number for information about Honda's I ndiana plant is

1-866-740-0086. 
Release date: October 11, 2006 from http://news.thomasnet.com/companystory/502571

--Not Relevant to Honda yet--

\section{Cummins to Produce Light-Duty Clean-Diesel Engines at Columbus Engine Plant}

COLUMBUS, IND. - Cummins Inc. (NYSE: CMI) today announced that it has selected the Columbus Engine Plant (CEP) here as the production facility for its new family of light-duty, clean-diesel engines, which the Company plans to begin manufacturing by no later than 2010. Preparations for the manufacturing lines are scheduled to begin in mid-2007 and are expected to create 200 additional jobs by the end of next year. Cummins expects the new line to employ at least 600 to 800 people within two years of the product launch.

DaimlerChrysler will be the major customer for the engine, which will be designed to power vehicles below 8,500 pounds gross vehicle weight for a number of automotive applications.

Indiana Economic Development Corporation from

www.in.gov/legislative/igareports/agency/reports/IEDC03.pdf

Kiehan IPT Mfg. Inc. will expand its operation in order to better compete in the global market, as well as to reduce operation and material costs. Additionally, the company will consider future product lines to add to be produced for Honda. As a result, the company has committed to hiring 70 new employees. 


\section{Welcome Honda! From http:/ / www.fctuckershelbycounty.com/ Honda.aspx Press Release}

GREENSBURG, Indiana (June 28, 2006) - Indiana will be home to Honda's new North American automobile plant. Governor Mitch Daniels today joined Honda executives from the company's North American operations to announce that the facility - which will begin production in fall 2008 and employ 2,000 people - will be located on 1,700 acres in Decatur County near Greensburg.

"Honda does business the way Hoosiers have always admired: with a commitment to the highest quality in their products and in their commitment to their co-workers, their neighbors and the entire community. Today, we are thrilled not just by the numbers but by the nature of these new jobs and the company that will bring them," said Daniels.

The governor returned early from an 11-day trade mission to Japan and South Korea after completing his entire official schedule. He remained in frequent telephone contact with Honda officials in the United States while on the trip.

According to Honda officials, the company will build a $\$ 550$ million facility in Decatur County beginning later this year. The plant will have an annual production capacity of 200,000 vehicles.

Combined state and local direct investment to support the Honda project includes EDGE tax credits, training assistance, and real and personal property tax abatements totaling up to $\$ 41.5$ million. In addition, there will be infrastructure support for water, wastewater and road improvements of approximately $\$ 44$ million. To accommodate future growth in the region, the state is expediting the longsought interchange upgrade on Interstate 74 , along with water, wastewater, and other road upgrades totaling approximately $\$ 56$ million.

Daniels utilized staff from several state agencies, including the Indiana Department of Transportation, the Department of Environmental Management, the Department of Natural Resources and the Economic Development Corporation to anticipate and find solutions to possible issues, such as road improvements, pre-permitting and utility needs.

In addition to local officials in Decatur County, the governor also recognized Lawrenceburg town officials for their commitment to the project. The Southeastern Indiana Government Grant Program will provide infrastructure assistance to the project. The city of Lawrenceburg initiated the grant program to stimulate growth, retention and improvement of the economic climate in nine counties in southeastern Indiana.

"After a record string of new-jobs announcements in 2005, Indiana is on a track to break that record again this year. Let's call it official - Indiana's economic comeback is underway," said Daniels.

Source: Office of Indiana Governor Mitch Daniels

What's Next for Decatur County and Greensburg? From http://www.indianaeconomicdigest.net/main.asp?SectionID=31\&subsection ID=67\&articleID=278 $\underline{58}$ 


\section{7/2/2006}

\section{By Kirk J ohannesen, The Republic senior reporter}

GREENSBURG - Honda Motor Co.'s decision to locate an auto plant in Decatur County finally has sunk in.

County leaders are beginning the work necessary to have the plant built by the targeted opening date of fall 2008.

Greensburg Mayor Frank Manus said work will begin immediately on the expansion of the wastewater treatment facility and water plant and building new roads.

"The amount of water they need is tremendous," Manus said.

The water plant initially handled 2.5 million gallons a day and was expanded to 4 million. Manus said the plant needs to handle 8 million gallons a day to accommodate Honda.

Building new roads and an interstate exchange by the plant - which was promised by the state as part of the deal - also begins immediately, Manus said. He said the exit by the site now is not conducive to traffic easily entering and exiting and heading east and west.

Manus said that the exit had been a problem for companies that were interested in the land.

Larry Jutte, senior vice president and general manager of Honda of America Manufacturing Inc., said that Honda also must deal with railroad track that runs through the land that will be used for the plant. He said Honda has been in contact with the rail company to move the track.

With the building process beginning, it's important to set plans for training future employees, Vicki Kellerman, executive director of the Greensburg/Decatur County Economic Development Corp., said. "I would think that there's some basic level of skills that would be required," Kellerman said. "We want to make sure that any of the training would be available to the local community so that they would have a year to prepare."

Kellerman said she's trying to get a list of training that might be required for employees of Honda and see if the training could be done at the Greensburg Community Learning Center or with the help of Ivy Tech State College. People have called Kellerman for several months inquiring about getting hired at Honda. She said she has a stack of resumes on her desk that she'll pass along to Honda at the appropriate time. Because people will be coming to Decatur County soon to begin work on the plant, and in waves during various stages of the project, the county mist answer meet basic needs, such as where to purchase certain goods and where to eat.

Melanie Maxwell, executive director of the Decatur County Visitors and Recreation Commission, said she is working with hotels to make sure their employees can answer guests' questions. She said that's important because not all hotel employees live in Decatur County. Maxwell is finishing a new brochure for Decatur County. The county's visitors and recreation Web site is being updated. "We have to make sure we have information ready to go," Maxwell said.

Steve Freeman, president of the Greensburg/Decatur County Chamber of Commerce, said the chamber is putting together information packages to give to newcomers. The packages would provide a list of chamber members and describe the services they offer. And with people coming to Decatur County, Freeman said it's important to make sure an adequate amount of housing is available, and to locate land that can be developed for residential or commercial use. Freeman said Realtors who are chamber members have been receiving calls from outside developers wanting to develop land. 


\section{Slow: High speed roadwork ahead for Decatur County near Honda site}

$5 / 17 / 2007$ from

http://www.indianaeconomicdigest.net/main.asp?SectionID=31\&SubSectionID=66\&ArticleID=34128

Daily News

\section{Greensburg Daily News}

Activity is expected to pick up around the Honda site as early as today when INDOT and its contractors start the heavy roadwork on U.S. 421.

Once the project starts, its momentum should carry it at breakneck speed.

"There is no other project like this one in Indiana," said Jason Bunselmeier, INDOT area engineer. "When you put the size of this project together with the very short timeline, this is definitely unique."

INDOT hosted a media tour of the project area Wednesday and laid out what the public can expect to see around the 1,700 acres that is Honda.

In all, there are six phases to the project but phase one will be the first thing the public experiences. That will include expanding U.S. 421 to four lanes with enclosed storm sewers and 16-foot, two-way turn lanes. It will also entail updating the State Road 3 and U.S. 421 intersection with new signals and turn lanes. That part of phase one will go as far south, across State Road 3 to the intersection of Michigan and Fourth streets. The entire phase is slated to be completed by next May.

The only closure during this phase will be on Old Michigan Road. This will be announced two weeks before access is cut off.

In addition, County Road 300 North is being moved a couple tenths of a mile north of it's present location.

"We'll be doing a lot of work in a short period of time," said Joe Jones, another INDOT area engineer. "It won't always be convenient or pretty, but we do want it to be done as safely as possible. We are asking for the public to bear with us."

During this segment of the project, Valley Asphalt Corporation from Cincinnati will be the most prevalent contractor. Principals there bid $\$ 25.88$ million for the US 421/Overpass Road project.

"Our fist significant deadline was to check the stability of the ground near Muddy Fork Bridge before May 27. We will hit that (today)," said general contractor Larry Barnes. "This is a fast-track job and that was a significant milestone to hit."

John Little, another one of the contractors, spoke about the scope of this project.

"It would be a simple job if we had two years to do it," he said. "Doing it in six months is a lot more difficult. That's an extremely tight time frame. We may go to 24-hour crews soon."

Once completed, 108,000 tons of asphalt will have been laid in the U.S. 421 area. Every one of those tons is a direct result of Honda calling Decatur County home. As the crews lay down the roads, a quick look to the west shows an equally impressive project going up on the Honda property as a 1-millionsquare-foot plant is erected. 
"I think Honda is doing rather well with their project," Bunselmeier said understating the massive steel structure he was looking at. "They are moving right along. Seeing what they are doing is absolutely a motivator for us to stay on schedule."

Once Honda is up and running, so will be an ever-increasing traffic flow. Currently, an average of 9,522 cars travel on U.S. 421 near the site. In the future, an expected 23,660 vehicles will make that road part of their daily travels, according to INDOT estimates and traffic surveys. 


\section{Honda plant in Alabama quickly outgrew initital projections from http://www.indianaeconomicdigest.net/main.asp?SectionID=31\&subsection ID=67\&articlelD=279 $\underline{59}$}

\section{Daily Journal of Johnson County By MI KE GEORGE and ANNI E GOELLER, Daily J ournal of J ohnson County staff writers $7 / 8 / 2006$}

The population of an Alabama town nearly doubles every day when people come to work. When Honda announced it was building a plant in Lincoln, Ala., a town with a population of about 4,800 , local officials expected more jobs. What they didn't know when the building was completed in 2001 was that there would be a fivefold increase in jobs during the next five years. More than 4,500 employees work at the $\$ 1.2$ billion plant. And along with those workers came another 4,000 jobs at 74 companies that supply the plant with equipment and parts. Before Honda came, almost none of those companies existed in Alabama. Now, they are clustered in about 10 counties around the plant, employing thousands of workers and bringing money to local communities. After Honda opened, a \$1 billion Hyundai plant opened in the state.

Many of those communities are within 30 to 50 miles of the main Honda plant. Johnson County lies within that range of a plant planned for Greensburg. If Johnson County economic development leaders want to land some of the spin-off businesses, they must be ready to market themselves and make sure to have highway access, Honda and Alabama officials said. With a new \$550 million Honda plant coming to Greensburg, Johnson County workers have a less than one hour drive to 2,000 new jobs. And at least three Franklin companies that supply Honda with parts could see a boom, meaning more jobs for local workers, too.

Interstate access is crucial for the suppliers that ship materials to the plant, said Edward Miller, senior manager of public relations for Honda of America. That means Johnson County companies and workers will need a quick route to Interstate 74 , not the current way through winding country roads. Alabama officials warned Indiana: Honda officials underestimated when they came to Lincoln, so be prepared for an increase in the workers and suppliers needed.

\section{Small town, big impact}

When Honda selected the Alabama site in 1999, officials estimated it would bring about 1,500 jobs with an investment of about $\$ 425$ million. After an expansion in 2002 , the plant employs 4,500 for a $\$ 1.2$ billion investment.

As the company grew, the supplier base grew, too, said Don Hopper, executive director of the Calhoun County Economic Development Council. The 74 companies that were moving into the area needed information about the schools, housing and the community for their future workers.

Local economic development officials had to be ready.

In many cases, the suppliers chose to move to the area without much persuasion from local officials. But that didn't mean officials could just sit back and wait, said Mike McCain, executive director of the Gadsden-Etowah County Industrial Development Authority. When Honda officials and suppliers went shopping for locations in his area, he was ready with a list of available properties and land and information about the local communities, such as income levels, schools and attractions in the area, McCain said. "We were proactive, but it was also good to be aggressively reactive when Honda officials started looking around for potential areas for their suppliers," he said.

In Talladega County, where the plant was built, the county had to widen some highways leading to the plant and provide better interstate access to the plant, said Calvin Miller, director of the Talladega County Economic Development Authority. 


\section{What it means for Indiana}

Potential for new suppliers might not be the focus in Indiana, but current ones could expand. For example, in Talladega County, local, existing businesses have seen a boom, such as office supply companies and a foam company located in the county, Calvin Miller said. One of the reasons Honda officials chose Greensburg for the plant was because of the proximity of parts suppliers in Ohio, said Edward Miller, the Honda spokesman. Honda in Greensburg is expected to generate $\$ 1.5$ billion in new business with suppliers, with about $\$ 900$ million in Ohio, he said. The company already has 64 suppliers in Indiana.

Some local suppliers will expand and some may look for new, larger facilities to make room for increased production, he said.

Honda keeps long-term relationships with suppliers. "Trying to get into the Honda family isn't necessarily an easy thing to do," he said. But the company also hires new suppliers every year, meaning Johnson County can still fight for new companies as well as more business for current suppliers, Edward Miller said.

\section{What Johnson County needs to do}

Regardless of whether Honda already has suppliers in the area, communities need a range of locations available for businesses, McCain said. "The most important thing for local communities is to be prepared," he said.

Some companies will need open land to build a plant large enough for specialized equipment needed to make their products. Others, such as those that make general products, will only need an empty facility they can move into, McCain said.

Any communities near the Honda plant should have a good business plan, sites ready for any prospective businesses and be prepared for discussions with companies, Edward Miller said. In Talladega County, large employers don't often build in the Lincoln area because they don't want to compete with the plant for a work force. Instead, the companies sprout up outside of Lincoln and in surrounding counties. That means counties outside the area for the new plant should be ready to meet with suppliers and potential suppliers. Some companies, especially some of the largest suppliers, are steadily shipping parts to Honda plants to keep up with production. Those plants need to be near enough to transport items quickly but also need a good shipping system, such as rails or highways, Miller said.

Communities need to be prepared to widen or improve roads and be sure to have good interstate access, he said.

"Because of the need for good and fast shipping, access to interstates is pretty much a given," he said. Communities near each other shouldn't compete for business. Honda officials like to see welcoming cities, towns and counties who work together to attract business to their area, Morrison said. 
Honda CEO: no plans for more North American expansion from

http://forum. thecarconnection.com/showthread. php?t=4562

Automotive News May 25, 2007 - 4:49 pm

INDI ANAPOLIS -- Despite steady sales gains, Honda Motor Co. has no immediate plans to expand North American output beyond opening a factory in Indiana, in 2008, CEO Takeo

Fukui said today.

"There is plenty of room to expand in Indiana, but we will look at the market before deciding to expand," Fukui said in remarks to journalists after a meeting with Indiana government officials here.

"Gas prices are high, but the American new-car and truck market will grow further in the future," Fukui said. "The current economic climate is having no impact on anything we are doing."

U.S. auto sales are down 3 percent this year, weaker than Honda executives forecast at the beginning of the year. The housing slump, record gasoline prices and slower economic growth are dampening consumer demand.

At the same time, higher raw material and product development costs have put a crimp on Honda's profits.

Honda's U.S. sales are up 1.6 percent, with car demand off 2.4 percent and light-truck sales up 7.1 percent. Helped by the Civic and Fit and the introduction of a redesigned Accord this fall, the automaker still expects its 2007 U.S. sales to rise 3.4 percent to 1.56 million units.

Fukui met with Indiana Gov. Mitch Daniels today and will attend the Indianapolis 500 on Sunday. Honda is supplying engines to the entire 33-car field.

The Japanese automaker is building a $\$ 550$ million assembly plant on a 1,700 -acre site in Greensburg, Ind., that will begin producing up to 200,000 Honda Civic sedans annually in fall 2008. Fukui toured the site today and received an update on construction.

Fukui said Honda is confident the United States can absorb another 200,000 units of capacity. While Detroit automakers are retrenching, Asia automakers are expanding across North America. Kia Motors Ltd. and Toyota Motor Corp. also are building new U.S. assembly plants.

Output at Honda's Lincoln, Ala., plant also has reached full capacity after a recent model changeover.

Honda will ship engines from a plant in Anna, Ohio, to the Greensburg site. And Fukui said it is likely that transmissions from Honda's Russells Point, Ohio, plant will be shipped to the Greensburg factory.

"We are dedicated to building and sourcing parts locally," he said. Because a majority of Honda's suppliers already are in Ohio, Michigan, Kentucky and Indiana, the Greensburg plant is not expected to generate a significant number of additional auto parts plants in the region.

When the Indiana plant is operating, Honda will be able to build the Civic at three plants in North America. 


\section{Honda to build a new factory in Indiana from http://www.msnbc.msn.com/id/ 13583311/}

GREENSBURG, Ind. - A $\$ 550$ million Honda Motor Co. assembly plant will help the Japanese automaker meet a growing North American hunger for its cars and help invigorate a state hit hard by manufacturing job losses, officials and analysts said. The southeastern Indiana plant - part of a \$1.18 billion global expansion - eventually will produce 200,000 vehicles annually, increasing Honda's North American production to 1.6 million a year. In 2005, American Honda sold 1.5 million Honda and Acura cars and light trucks, and the continent accounts for about half Honda's annual global sales, the company said. Honda officials expect its sixth North American plant will help meet that growing demand.

"We believe that the great state of Indiana has what we need to continue that success: an outstanding community of people, excellent transportation systems and the necessary infrastructure to support industry," Koichi Kondo, president of American Honda Motor Co., said during Wednesday's announcement in Greensburg.

Four other states - Ohio, Michigan, Wisconsin and Illinois - vied for the plant and its 2,000 jobs after Honda announced in May it would build a plant in the Midwest. But Indiana, which has lost 98,000 industrial jobs since 2000, persuaded the company to build on 1,700 acres west of Greensburg, midway between Indianapolis and Cincinnati on Interstate 74. Gov. Mitch Daniels, who returned to Indiana early after an 11-day trade trip to Asia, welcomed Honda officials. "Honda is going to feel right at home in Indiana, and you are going to love Greensburg and this part of our state," Daniels said.

Indiana offered $\$ 141.5$ million in incentives to the company, which included tax credits and abatements, training assistance and a promise to expedite the long-sought interchange upgrade at U.S. 421 onto I-74, state officials said. Many analysts had believed Ohio had the edge for the new plant because of its existing Honda facilities. Honda turns out 680,000 vehicles a year at two Ohio plants.

It also has an engine plant and transmissions plant there, as well as 150 supplier locations - nearly four times as many as Indiana. "The large number of Honda suppliers and plants that already exist in Ohio may have resulted in our being victims of our own success," he said. 
The company also has one plant each in Alabama, Canada and Mexico. Indiana welcomed the factory, saying its jobs will help boost the state's economy. "The Indiana comeback is under way," Daniels said.

Though Honda expects to hire 2,000 workers, the number could end up being far more, said J ohn Sullivan, director of Purdue University's Center for Advanced Manufacturing. Toyota initially said it would hire 1,300 people at its Princeton plant when it broke ground 10 years ago, he said. Today, it has about 4,700 workers.

An operation like a Honda plant typically generates jobs at supplier plants, which will be located within 500 miles - close enough for just-in-time deliveries of parts, Sullivan said. Retailers and restaurants will also benefit from the working spending their earnings, Sullivan said.

"I think that that part of Indiana is in need of high-paying jobs, and I think you'll see quite a transformation," he said. Christy Kinker, who owns Christy's Cakes and Confections in Greensburg, hopes Sullivan is right. She displayed a hand-drawn sign in the window that read, "Welcome Honda." "We're just excited about the business," the 30-year-old Decatur County native said Wednesday. "We hope it will help the small mom and pop businesses and bring more money to the area."

Honda's Kondo was enthusiastic about the company's first Indiana plant and noted that all drivers in this year's Indianapolis 500 used Honda engines. "I'd like to point out that there was not one engine failure in the race," he said. "With the racing spirit in mind, today I am happy to be able to say, 'Honda and Indiana, start your engines."'

Construction will begin in the fall and be completed in 2008. Kondo declined to say which vehicles would be produced, although the cars would be four-cylinder models. The Anna, Ohio, plant, about 100 miles away, will provide the engines.

Honda and its larger rival, Toyota Motor Corp., have been rapidly expanding their North American manufacturing capacity to keep up with demand even as U.S. automakers General Motors Corp. and Ford Motor Co. are cutting thousands of jobs and closing plants as their market share declines. 
Honda already has options on land near Greensburg, a community of 10,500 people 50 miles southeast of Indianapolis. Planning officials were to meet Wednesday to discuss rezoning the area for the plant 


\section{Honda supplier announces I ndiana factory from}

http://www.abcmoney.co.uk/news/09200737103.htm

NEW CASTLE, Ind. (AP) - A Japanese company plans to start construction next month on a $\$ 32$ million factory that will employ 300 people and churn out about 800 car seats a day for the new Honda Motor Corp. plant being built in Greensburg.

The 200,000-square-foot factory operated by TS Tech also will make interior trim pieces for Honda automobiles, according to the Indiana Economic Development Corp., which stated that the seats will be used for Honda Civics.

Honda spokesman Ed Miller said the seats will be used in Greensburg, about 40 miles south of New Castle in eastern Indiana. But he declined to confirm whether Civics will be made there.

Honda has said only that the new factory will make a car powered by a four-cylinder engine made in Ohio. Construction has already started on the plant, which will employ about 2,000 people when it opens in the fall of 2008 .

The TS Tech factory, which will be built outside New Castle, should start production in August 2008.

Honda has 525 suppliers in the United States and expects only a handful to build new factories for the Greensburg plant, Miller said. Most will expand existing locations.

'We expect a few more announcements like this, however, our decision to build an assembly plant in Indiana was driven by the efficiency of having a large supplier base in place in the Midwest,' he said. He said Honda uses 'just-in-time inventory' for its car seats, meaning that they are delivered to the assembly plant a few hours before installation. Those suppliers need to be close to the factory. 


\title{
Honda Chief Deflects Currency Snag from
}

\section{http:/ / ww w.indystar.com/ apps/ pbcs.dll/ article?AI D =/ 20070526/ BUSI NESS/ 7 $05260477 /$}

\author{
By Ted Evanoff May 26, 2007
}

Detroit's Big Three, a pillar of Indiana's industrial economy, have graying autoworkers, expensive pensions, stiff health-care obligations -- all making their costs higher than Japanese rivals with younger work forces.

But he shrugs off the latest culprit Detroit has singled out as a source of its problems -- Japan's deliberate manipulation of the yen.

"The companies are struggling right now, so with issues like this they are trying to generate more talk among certain politicians," Takeo said Friday in an interview, speaking through translator David lida, a Honda employee.

A U.S. trade group backed by Chrysler, Ford and General Motors has been complaining about the Japanese government, contending Tokyo's yen manipulation subsidizes Japanese automakers by giving them an unfair cost advantage on cars they export to the United States.

The advantage means prices on imported autos can be reduced and still bring in strong profits, argues the Automotive Trade Policy Council, in Washington.

"While the yen is at a very undervalued level, they are taking advantage of that by exporting automobiles in record numbers to the U.S.," said Charles Uthus, trade council vice president. The issue hits home in Indiana, a new haven for Japanese auto assembly as well as a traditional bastion of Big Three auto-parts suppliers employing 75,000 throughout the state.

When the Big Three complained about imports in the 1980s, Japanese automakers responded by opening assembly lines in North America. Another robust Japanese expansion is under way now, stabilizing Indiana's industrial economy as Detroit cuts parts orders and jobs.

Honda's Civic car assembly plant going up in Greensburg will open in 2008. Toyota last month launched Camry sedan production at the Subaru car plant in Lafayette, which is continuing with Subaru output. Toyota's two major assembly plants near Evansville, built in the last decade, turn out minivans, sport utility vehicles and pickup trucks.

Japanese automakers now have 35 percent of the U.S. market, compared to 25 percent a decade ago. Although more than a dozen Japanese auto-assembly plants run in the United States, imports still are growing. For example, imports from Asia account for 24 percent of the autos Honda has sold in the United States this year through April, compared with 18 percent a year ago, according to market researcher Morgan \& Co. of West Olive, Mich.

Analysts say imports rose with a strong U.S. car market. Takeo indicated that the demand for Hondas has nothing to do with currency manipulation.

"If you look at the facts of the matter, the Japanese government hasn't been involved in the currency markets for three years," Takeo said.

In Washington, the trade group disagrees. It contends Japan has amassed an $\$ 8.8$ billion trade surplus and currency reserve. Keeping the money on hand, rather than investing it abroad, amounts to a deliberate strategy to undervalue the yen, Uthus said.

On Friday, $\$ 1$ was worth 122 yen, which the trade group says gives Japanese automakers a $\$ 4,000$ per-vehicle cost advantage on imports that would ease if $\$ 1$ were worth 90 yen.

"The Japanese are taking advantage of the yen right now," Uthus said. "What they're doing is building capacity in Japan for more exports.

Honda President Fukio Takeo is in town for the Indianapolis 500, the first Indy race he will have seen. After lunch Friday with Gov. Mitch Daniels in the official governor's residence, Honda's No. 2 executive fielded questions from reporters. Here are some of his remarks:

Construction of Honda's Greensburg assembly plant is on schedule. Hiring of the 2,000 autoworkers will begin in the fall.

Don't expect to see a lot of suppliers come into Indiana to make auto parts for the Honda Greensburg 
plant. Honda chose Southeast Indiana for the 2,000-employee plant in part because the region is close to existing suppliers for Honda's massive Ohio automaking complex.

The Greensburg plant will assemble 200,000 Civics a year, joining Honda plants in Ontario and Ohio that also make the small car. One of the plants eventually will convert to production of another model if Civic sales ease. Honda's Ohio engine plant will supply the Greensburg Civic. Transmissions could come from Ohio and/or Alabama.

Having acquired 1,700 acres at Greensburg, Honda has plenty of expansion room but no expansion plans in the works now for Greensburg.

Are car exports from China a worry? No. "They still have quite a way to go before they are directly competing in the U.S.," Takeo said through translator David lida. Indiana's skilled workers have impressive abilities on the job. And any place as enthusiastic about car races as Indiana has to have good autoworkers. What was his thought when he saw the Greensburg plant under construction for the first time this week? "I was impressed by the scale of the site. It looks very much like our Ohio operation." 
Greensburg Secures Loans For Water Infrastructure For Honda Plant --5/31/2007

\section{http://www.insideindianabusiness.com/newsitem.asp?ID=23619}

\section{Press Release}

INDIANAPOLIS - The City of Greensburg closed on two loans today totaling \$15.6 million through the Indiana Finance Authority (IFA)'s State Revolving Fund (SRF) Loan Programs for wastewater and drinking water infrastructure projects. By utilizing the low interest rates offered by the SRF Programs, the City will save an estimated \$5.5 million in interest - a third of the project amount - over the life of the 20-year loans.

"I think it's great that the SRF Program is providing the amount of money that they are for our projects. Without the interest savings it would have been very hard for us to afford," said Mayor Frank Manus. "The design will construct infrastructure to the Honda plant as well as provide for Greensburg's needs through 2026 while saving tax payers money."

The SRF Program has also committed to additional funding at zero percent for other projects in the planning process.

A \$7.12 million Drinking Water SRF Loan, which qualified for a zero percent interest rate, will finance construction of a 1 million gallon elevated storage tank, more than 22,000 feet of water main, 19 fire hydrants, valves and engineering costs. The community also closed a $\$ 8.5$ million loan for wastewater infrastructure, on which the lower-than-market rate of $4.39 \%$ will save an estimated $\$ 987,000$.

"I’m glad Greensburg was able to take advantage of this opportunity,” said Sen. Bob Jackman. "They have many important projects just like any other community and, in addition, they have to prepare for Honda. By taking advantage of this program, they can complete necessary projects and thanks to the low-interest rates they will be saving taxpayers a considerable amount of money."

Governor Mitch Daniels created the Indiana Finance Authority (IFA) in 2005 to more effectively manage Staterelated financial programs such as the Wastewater and Drinking Water SRF Programs under one entity. Since the inception of the IFA, the SRF Programs have loaned more than \$492 million to local communities at belowmarket interest rates, saving utility customers more than $\$ 82$ million in interest.

“The SRF Programs provide Indiana communities with a unique opportunity to save money while addressing much-needed wastewater and drinking water improvements,” said Ryan Kitchell, Public Finance Director. "Governor Daniels is very focused on the health of Hoosiers. We are pleased to provide an economical way for communities to offer a cleaner environment and excellent quality of life for current and future residents of our State.”

Communities can learn more information about obtaining a State Revolving Fund loan by contacting Bill Harkins at (317) 234-4862 or wharkins@ifa.in.gov or by visiting http://www.in.gov/srf. 
http://www.indianaeconomicdigest.net/main.asp?SectionID=31\&subsectionID=70\&articleID=32866

Feeling Honda's effect in Johnson County

\section{By ANNI E GOELLER, Daily J ournal of J ohnson County staff writer}

Two Franklin companies could benefit from Monday's announcement that Honda Civic sedans will be produced at the new plant in Greensburg.

NSK Corp. and KYB Manufacturing North America Inc., two automotive manufacturers in Franklin, make parts for the Civic and could get more business based on Honda's needs.

KYB already has started an expansion, which would more than double the size of its building, to prepare for both the new Honda plant and when Toyota begins production at a plant in Lafayette, said David Billingsley, president of the KYB Franklin plant.

The contract between NSK and Honda hasn't changed, but the company could increase the number of parts they get from the Franklin plant, said Jim McGinnis, human resources manager. NSK makes wheel bearings for the Honda Civic and the Accord.

Honda conducted a ceremonial groundbreaking for the $\$ 550$ million vehicle assembly plant at the Greensburg site Monday and made the announcement about the Civic sedan, a staple of the car company.

"Building the Civic is a big responsibility," said Koichi Kondo, president and CEO of American Honda, at the ceremony that Gov. Mitch Daniels also attended. "That should tell you how confident we are in the people of Indiana."

The factory, part of a $\$ 1.18$ billion global expansion, eventually will produce 200,000 vehicles annually, increasing Honda's North American production to 1.6 million a year. The Japanese automaker has said the plant will employ about 2,000 people when it opens in fall 2008

NSK and KYB supply parts to Honda's plant in North Liberty, Ohio, which also produces the Civic.

Company officials have not yet made a decision on whether the Civic will continue to be made at the Ohio plant as well as the Indiana plant. As of now, both plants will make the Civic, said Alicia Jones, spokeswoman for Honda.

Honda is KYB's second-largest customer behind Toyota, Billingsley said.

The company already was gearing up for a bigger workload before the announcement came that the Civic would be produced at the Greensburg plant. KYB supplies shock absorbers and struts for all fourdoor Civics in the U.S. and Canada, he said.

A new Honda plant means more work for the company, which also supplies parts for the Honda Element, the Ridgeline and a luxury vehicle made by the company.

"As they continue to grow and add plants and market share, KYB will continue to grow," Billingsley said.

Construction already has started on the expansion, which will add 51 jobs and 260,000 square feet to the 220,000-square-foot building. The expansion is expected to be completed by spring 2008.

And the company has more room on its 52-acre site for future expansions, Billingsley said. 
"We can expand more. That would be our intention. We don't intend to leave Johnson County," he said.

Billingsley wouldn't say how much business KYB gets from Honda yearly, but said they receive orders daily.

The new Honda plant is expected to produce 200,000 vehicles per year.

That added work would be in addition to the 100,000 vehicles that will be produced when Toyota moves into an existing Subaru plant in Lafayette, he said.

Both automakers will need time to train workers and get set up before reaching their maximum production amount, but KYB wanted to prepare ahead of time, Billingsley said.

The Associated Press contributed to this report

Meeting Minutes

Greensburg: COMMON COUNCIL MEETING

SEPTEMBER 5, 2006

TIME: 6:00 P.M.

Present: Mayor Frank Manus, Glenn Tebbe, Gary Herbert, Larry Bower, Ken

Dornich and Helen Gardner.

Pledge of Allegiance was recited.

Minutes were approved.

Attorney Richard Hall of Barnes \& Thornburg introduced Gary Malone and David

Frederick of H.J. Umbaugh to explain the preliminary financing plan for the

Honda project infrastructure. Total cost estimates for the needed infrastructure

improvements are: Water $\$ 25,900,000$; Wastewater $\$ 13,000,000$ and Roads

$\$ 12,000,000$. Revenues to pay for the expenses will come from revenue bonds

based on Water and Wastewater revenues from Honda usage and from

Greensburg Tif and the new Decatur County Tif, where Honda will be located.

Also a \$10 Million grant from the City of Lawrenceburg will cover most of the road

improvements. Improvements and infrastructure costs for Honda will not raise

our utility or tax rates.

Shelbyville:

\section{COMMON COUNCIL}

Regular Meeting

July 3, 2006

Also in old business, Mr. Schrumpf was present representing Ryobi Die Casting, Inc. on their compliance with statement of benefit forms. Mr. Schrumpf reported that Ryobi will soon experience a growth in employee population and that they have added a line to supply Honda. Councilman Fero moved to approve the compliance with statement of benefit forms for Ryobi Die Casting, Inc, and Councilman Fero seconded. There was no public comment. The motion was carried on a 6-0 voice vote. 


\author{
Rushville: RUSHVI LLE CITY COMMON COUNCI L \\ TUESDAY, SEPTEMBER 5, 2006 \\ 6:00 P.M. \\ MAYOR'S REPORT * \\ Mayor Bridges reported the following: \\ * I will be meeting with a small group of Mayors in Greensburg tomorrow to \\ discuss the possible impact that Honda could have on Rushville. I will \\ keep you informed of the outcome and discussion points of the meeting. \\ * I have been invited and would encourage any of the City Council who \\ might be interested to attend one of three community meetings on the \\ subject of workforce and how Honda's new North American plant may \\ affect our region. I sincerely believe that workforce may be one of the \\ most important singular factors to this region with Honda locating in \\ eastern Indiana, and we need to be ready when that relocation effort \\ begins. The dates of the meeting are Tuesday, September 12th at the \\ Greensburg Learning Center, 422 Central Avenue in Greensburg; the \\ second meeting will be held on Wednesday, September 13th in Columbus, \\ at the Columbus Learning Center, 4555 Central Avenue, Columbus, \\ Indiana; and the third will be held in Shelbyville at the Blue River Career \\ Center, 801 St. J oseph Street, Shelbyville, Indiana. All meetings will be \\ from 8:30 a.m. to 10:30 a.m.
}


http://www.indianaeconomicdigest.net/main.asp?SectionID=31\&subsectionID=62\&articleID=31821

2/1/2007 3:53:00 PM

Email this article $\cdot$ Print this article

Connersville's Visteon plant will close Sept. 1, affecting all 890 employees

\section{IBJ Editorial Staff}

Visteon Corp. officials informed employees in their Connersville plant today that the facility will close Sept. 1.

All 890 employees at the Connersville plant about 60 miles southeast of Indianapolis will be affected, said Kimberley Goode, spokeswoman for Michigan-based Visteon.

Goode said it is not clear if those employees will be terminated, given severance packages or opportunities for re-assignment within the company.

"The employees are just being notified this afternoon, and the details are being worked out," Goode said.

"After a thorough review, we do not believe there is a viable business case to continue operating the plant," Joy Greenway, vice president of Visteon's climate group, said in a statement. "Visteon is committed to taking necessary action as part of our ongoing effort to restructure our business and improve our operations. We are proud of our workforce and recognize the impact of such a decision on our employees, unions and the local community, with whom we have a positive relationship."

The plant makes components for auto air-conditioning and fuel injectors. The Ford supplier plans to phase out operations as products reach the end of their production cycles.

The closing will be a massive blow to Connersville and nearby communities. The cuts approach nearly one-third of the manufacturing work force in Fayette County, according to government statistics. 
Local officials in Shelby County expect profound impact from new Honda plant

$6 / 28 / 2006$

Shelbyville News

Bettina Puckett, Shelbyville News Staff Writer

Local officials are practically giddy with excitement about the news that American Honda Motor Co. may build a new North American auto plant in nearby Greensburg.

An official announcement is expected to be made at 10:30 a.m. today during a news conference at the Greensburg Community Learning Center.

Many elected officials who were contacted Tuesday evening were politicking at the Shelby County Fair.

"This could be one of the most exciting things that's ever happened to Shelby County — even if it's in Decatur County," said Shelbyville Mayor Scott Furgeson.

Furgeson said the plant would benefit a number of businesses in Shelby County. "We already have Japanese companies here that are doing business with Honda," he said. "(The new plant) will further their growth."

The $\$ 400$ million plant would employ 1,500 workers and produce 200,000 vehicles per year.

Furgeson said that one "down side" — at least during the short term — is that the high-paying Honda jobs might lure local workers away from jobs here in Shelby County. "The plant could deplete our workers," he said. "It could be hard on our existing industry to fill those (lost) jobs. Obviously, we'd like to keep the jobs we have now."

However, one major benefit could be housing. Honda workers - especially those with a spouse who works in Indianapolis - may find Shelbyville's location the perfect setting in which to live. "With our proximity between Indianapolis and Greensburg, people who lived here would be 20 minutes from work and 30 minutes from Indianapolis," Furgeson said.

"We're going to get the existing industries that will be benefiting from it, plus some new (companies) out of it," Furgeson said. "This will be a big plus for us." Tony Newton, a Shelby County commissioner who represents the South District, said the location of the 1,656-acre plant is about 15 minutes from his home near Waldron. "It's only six or seven miles from the St. Paul exit (on Interstate 74)," he said. "I think it will be tremendous," Newton said. "We're in a good position here. The plant will create several spin-off businesses and suppliers." Newton said he does not believe that Honda will be looking to fill "general-labor" type of positions. "Most of those jobs will be skilled labor, like machinists and tool-anddie workers."

Honda will likely draw workers from 75 to 100 miles away, including those living in Indianapolis and Cincinnati, Newton said. "They will be flooded with job applicants," he said.

The jobs will not be available overnight. But Honda officials hope to have the plant built by 2008 .

Sean Eberhart, president of the Shelby County Council, said the plant will bring nothing but good news to the area.

"I think we'll benefit just as much as Decatur County will, although we won't see the property tax revenue come in. But we're close enough to that site that we'll see suppliers, plus some of their workers will live here."

Eberhart said the only thing that would have been better would have been to have the Honda plant locate in Shelby County. "But if we can't get it, it's nice that a neighboring county can get it," he said. "I think Honda will be an excellent neighbor and community partner for Greensburg." Eberhart said it is 
exciting to think that many of the Honda workers may make their homes in Shelby County. "It would be a logical location since we are between Greensburg and Indianapolis," he said. "I hope we are receptive to them as a community. I want to open my arms up to them and welcome them. I hope that's the way we all approach it."

Bob Carmony, a member of the Shelby County Council, said the Honda plant could affect Shelby County industry and its labor force. "It will have a big impact on the job training efforts in Shelby County," Carmony said. "I would look for a big increase there. We would also see a pretty big increase in housing with Shelbyville being halfway between Indianapolis and Greensburg. It will be interesting to see where the dust settles." Carmony said he believes there will be continued efforts to increase the "educational inventory" in Shelby County to train future workers. Past endeavors have included bringing Indiana Wesleyan University's satellite campus to Intelliplex, Shelby County's certified technology park. Intelliplex also features Purdue University's regional Technical Assistance Program, which assists businesses with developing new technologies and manufacturing processes.

On May 17, Honda officials said they planned to build the new plant in the Midwest as part of the company's $\$ 1.2$ billion global expansion. Ohio, which already has two Honda plants, was also in the running. Officials have said that the Honda plant would help to invigorate Indiana's economy, which has lost 98,000 industrial jobs since 2000. Honda opened its first U.S. plant in 1979 and directly employs more than 25,000 Americans, according to its Web site. More than 100,000 workers are employed at authorized Honda automobile, motorcycle and power-equipment dealerships in the United States. Tens of thousands of additional Americans are employed by more than 600 U.S. suppliers from which Honda purchases parts and materials 
---From http://www.expansionmanagement.com/statespotlights/Indiana/18643 on June 18, 2007

Honda Supplier Tomasco Breaks Ground on Manufacturing Facility Expansion in Winchester, Indiana

Winchester, In (May 7, 2007) Tomasco recently ground on the expansion on the company's manufacturing facility in Winchester, Ind. The $\$ 29$ million project will nearly double the company's Indiana work force and will add a parts manufacturing line that will supply the new Honda plant near Greensburg, Ind. Construction of the 127,000 square foot expansion project will begin later this month, and company officials expect to begin full production at the site in late 2008.

"Honda's announcement of its Greensburg plant created a great opportunity for Tomasco to grow in Indiana," said Tim Peterson, Tomasco's vice president of manufacturing. "With our existing facility in Winchester and our excellent team of associates, this is a great growth opportunity for Tomasco and the economy of East Central Indiana."

Tomasco currently employs more than 130 in Winchester and produces a myriad of metal hinges, locks and brackets for Honda. Indiana's economy continues to feel the positive impact of Honda's decision to build a new production facility in Decatur County near Greensburg. Interior parts supplier TS Tech announced in March that it would locate a new production facility in New Castle to supply the new Honda plant. In 2006, Toyota announced it would build its Camry in Lafayette, and Cummins announced its plans to build its new family of light-duty clean-diesel engines in Columbus. Collectively, the three manufacturers expect to create more than 3,800 jobs and invest more than $\$ 1$ billion in their Indiana operations. Established in 1999 as Tomasco Indiana LLC, the company specializes in stamping and welding. Tomasco, a Tier 1 supplier to Honda, logged \$16.4 million in sales in fiscal 2006. 


\title{
American Honda Opens New Midwestern Consolidation Center in Troy, Ohio $\$ 89$ Million Parts Distribution Facility to be 'Green Building'
}

\author{
J une 13, 2007 from \\ http://world.honda.com/news/2007/c070613ConsolidationCenterinTroy/
}

\begin{abstract}
TROY, Ohio, U.S.A., June 13, 2007 - American Honda Motor Co., Inc. opened its $\$ 89$ million Midwestern Consolidation Center in Troy, Ohio, a key hub that will supply Honda's nine other parts distribution centers throughout the U.S. The 549,000 square foot (sq. ft.) facility was designed to achieve Leadership in Energy and Environmental Design (LEED) certification by the U.S. Green Building Council (USGBC). Consisting of 500,000 sq. $\mathrm{ft}$. of warehouse distribution space and 49,000 sq. $\mathrm{ft}$. of office space, the facility is located on 58 acres adjacent to American Honda's existing parts distribution center, which has been operating in Troy since 1986. The hub also houses a procurement operations support office that is already functioning in the new facility, including 100 of the procurement associates who were relocated from the neighboring facility. The warehouse will be fully completed and begin operations later this fall and will include the creation of 110 new full-time jobs.
\end{abstract}

"This centrally-located facility will enable us to provide the highest level of service to our customers by enhancing timely distribution of parts and materials and improving inventory management," said James Roach, senior vice president of American Honda's Parts Division. "More than 530 Honda suppliers in 33 states provide parts and materials to create Honda and Acura products and this center will be organizing and distributing parts from this growing U.S. supply base."

As part of Honda's commitment to environmental sustainability, the new Troy distribution center was designed and constructed utilizing environmentally friendly products and materials. American Honda is working with the USGBC to earn the organization's Gold rating LEED certification including many energy-saving attributes such as an Energy Star reflective roof to reduce heat gain and lower air conditioning requirements; reclaimed water used for landscaping; and an intelligent lighting system that makes greater use of natural light. Honda has other LEED gold certified facilities in Gresham, Oregon and Raymond, Ohio; and, also anticipates that its newly-opened Acura Design Studio in Torrance, Calif. will achieve gold certification.

American Honda currently employs approximately 340 full-time associates at the existing Troy facility. Upon completion of the new facility, approximately 110 new full-time warehouse positions will be created with total employment at the new warehouse facility expected to exceed 200 associates.

American Honda's Parts Division handles the marketing, purchasing, inventory and distribution of genuine Honda parts and accessories for all Honda products, shipping to about 1,300 Honda and Acura dealers nationwide.

Honda began operations in the U.S. in 1959 with the establishment of American Honda Motor Co., Inc., Honda's first overseas subsidiary. Honda began U.S. production operations in 1979. Honda now employs more than 28,000 Americans in the designing, manufacturing and marketing of its products in America. Honda currently builds products in 13 manufacturing plants in North America, with three major $R \& D$ centers in the U.S. 


\section{Direct Economic Impact 1978-2003 From http:/lohio.honda.com/Ohio/direct.cfm}

This chapter of the Study examines the direct economic impact of Honda in Ohio in terms of investment, employment, earnings and production. It traces the importance and resulting impact of key business strategies that Honda executed. Findings clearly show the benefit to Ohio from Honda's growth beyond vehicle assembly to become Honda's North American operations hub:

- Honda is Ohio's top manufacturer of motor vehicles.

- Honda employs more than 16,000 Ohioans, with total wages exceeding $\$ 1.1$ billion annually, is a top-15 Ohio employer, and has never had a layoff.

- Honda has invested \$6.1 billion in Ohio since 1979.

- Honda's investment of $\$ 5.3$ billion in manufacturing in Ohio represents more than 80 percent of Honda's total U. S. investment in manufacturing.

- Honda's vehicle, engine and transmission production output in Ohio since 1979 exceeds \$178 billion.

- Honda's vehicle, engine and transmission production output in Ohio in 2003 exceeds \$16 billion.

- Honda has received the Governor's Excellence in Exporting Award 3 times since 1995.

\section{Supplier Impact from http://ohio.honda.com/Ohio/supplierImpact.cfm}

One of the factors in Honda's decision to locate in Ohio was Ohio's location in the industrial Midwest, including the availability of a motor vehicle parts supply base. This chapter examines Honda's Ohio suppliers of parts and raw materials and their impact on Ohio's economy. It is clear that the number and scope of supplier operations in more than half the counties in the state contribute to economic activity in nearly every region in Ohio:

- Honda has played a significant role in making Ohio the second leading producer of auto parts in the U.S.

- 154 Ohio suppliers, located in 52 of the state's 88 counties, supply parts and materials to Honda's North American plants.

- These suppliers made investments in excess of \$1.56 billion in Ohio between 1990 and 2002.

- Honda purchases $\$ 6.8$ billion annually from these Ohio suppliers.

- These suppliers employ a total of 40,776 associates, nearly half of whom are directly involved in manufacturing for Honda.

- These suppliers pay total wages estimated at $\$ 1.2$ billion annually with approximately $\$ 550$ million paid to employees directly involved in manufacturing for Honda.

- These workers pay an estimated $\$ 38.3$ million in state and local income taxes annually, \$17.6 million of which are paid by employees directly involved in manufacturing for Honda. 


\section{Economic Multiplier Effect from http://ohio.honda.com/Ohio/multiplier.cfm}

When Honda and its suppliers create jobs and pay wages and salaries, much of this income is spent and re-spent on goods and services produced in the local and regional economy where they are located. This chapter examines the "ripple" or "multiplier" effects that can be attributed to Honda's growth in Ohio. To estimate this multiplier effect on the economy, this Study has utilized a sophisticated model developed by the U.S. Department of Commerce Bureau of Economic Analysis known as RIMS II (Regional Input Output Modeling System). This model captures the ripple effects on the economy across 3 dimensions:

1. Direct Economic Impact - The expenditures, jobs and income created directly by Honda's operations in Ohio (discussed in Chapter 1 of this Study).

2. Indirect Supply-side Economic Impact - The economic ripple effects on industries related to Honda as a result of Honda's expenditures (the first stage of which is discussed in Chapter 2 of this Study).

3. Induced Demand-side Economic Impact - The broad economic impact from increased consumption by Honda associates and employees in related industries.

This Study expresses these economic multiplier effects in terms of economic output, employment and earnings:

- For each $\$ 1$ in output Honda produced in 2003, it generated an additional \$1.1 dollars statewide creating a total Ohio output multiplier of 2.1.

- As a result of the output multiplier of 2.1, Honda's 2003 total output of $\$ 17.1$ billion increases total output in Ohio to $\$ 36.0$

billion.

- For each of the 16,049 jobs Honda directly provided in 2003 , another seven jobs were generated statewide for a total Ohio employment impact of 128,406 jobs (and a total employment multiplier of 8.0).

- For each $\$ 1$ Honda paid in wages during 2003, another $\$ 3.3$ dollars in earnings were generated in Ohio, creating a total earnings multiplier of 4.3.

- Honda's \$1.13 billion in wages and salaries paid to its associates in 2003 results in a total Ohio earnings impact of $\$ 4.85$ billion.

- As a result of Honda's long tenure in Ohio, the comprehensive scope of its operations in the state, and the large reliance on Ohio suppliers of parts and raw materials, the economic multiplier effects found here are significantly significantly larger than those found by other comparable studies of automakers in other states. 


\section{Fiscal Benefits to Ohio from http://ohio.honda.com/Ohio/fiscalbene.cfm}

The state of Ohio provided $\$ 26.9$ million in direct incentives to Honda from 1977-1988. The state also invested \$64.4 million in highway funding for improving and widening U.S. Route 33 , for a total state investment of $\$ 91.3$ million. In return, Honda and its

associates have paid a total of $\$ 1,087.1$ million in taxes from 1979-2003.

The soundness of the investment by the state and the significant return on that investment can be measured:

- Ohio has realized a significant rate of return on both its $\$ 26.9$ million direct investment in Honda and its $\$ 64.4$ million indirect investment in the widening of Route 33.

- The cumulative net fiscal benefit from 1979-2003 of Honda's presence in Ohio is conservatively estimated at $\$ 996$ million.

- The Honda of America Manufacturing and Honda Engineering North America subsidiaries and their associates have paid more than $\$ 1$ billion in taxes since 1979 , and now pay over $\$ 100$ million annually.

- For each $\$ 1$ the state spent on direct incentives, it has received nearly $\$ 40$ in revenue benefits from the HAM and EGA subsidiaries of Honda alone.

- For each $\$ 1$ invested by the state in direct incentives, Honda has invested $\$ 226$.

- For each $\$ 1$ invested by the state in both direct and indirect incentives, Honda has invested $\$ 67$.

- 53 cities and 43 school districts benefit from the income tax receipts they receive from Honda and its associates. 


\section{Batesville Tool and Die}

http://www.allbusiness.com/north-america/united-states-indiana/543727-1.html from Indiana Business Magazine, Jennifer Cone-Ertel

Every day, 16,000 blower-motor cases are produced and shipped from Batesville Tool \& Die to Bosch Automotive Motor Systems. A hulking 600-ton press has to perform 15 sequences perfectly to ensure the soundness of the parts, which are roughly the size and shape of a vegetable can and are found on every Ford car. Very few U.S. companies are outfitted with the technology to handle such a job. The ability to what the industry refers to as "deep-drawn" parts is what has made Batesville Tool \& Die a success.

Guaranteed delivery and zero tolerance for defects are crucial requirements in the metal-stamping industry. "Our customers pick up goods intended for production use the following day," says Jody Fledderman, the company's president. "Less than 100 percent delivery on our part could shut down an automotive plant. Putting a thousand persons out of work is just not an option for us. Period. We just don't do it."

While Batesville Tool \& Die does design, build and maintain the tools and dies that fit into the company's presses, its name is deceiving because its primary business is the stamping of steel parts, not traditional tool-and-die work. The company produces more than 500 different parts for more than 40 customers across North America, including Bosch, Ford, General Motors, Honda and General Electric. The vast majority of its sales - 84 percent - are linked to the automotive industry, with 14 percent going to the appliance industry.

Batesville Tool \& Die is the second-largest employer in Batesville, after Hillenbrand Industries. Nearly all of Batesville Tool \& Die's 450 employees live in nearby communities. Fledderman believes the company's success is closely linked to the agricultural work ethic among local residents.

In 1978, Fledderman's father, Ron, double mortgaged the family home to purchase a couple of used presses and a 600-square-foot building. Together with two friends and a cousin, he started Batesville Tool \& Die. Jody Fledderman, who was in high school when the company was founded, took over as president in 1990. The elder Fledderman remains chairman of the board, and 23 of the company's 29 stockholders still work at the plant full-time every day.

The past few years have seen impressive growth at Batesville Tool \& Die. Sales grew 27 percent in 1991, 8 percent in 1992, 17 percent in 1993, 34 percent in 1994 and 25 percent last year, reaching \$62 million. The firm has added more than 200 employees since 1991.

For this year, however, the company has chosen to hold growth to a manageable 6 percent so that it can make necessary adjustments and build upon its technical expertise.

"Growth can be good or bad; it's bad if it isn't managed correctly," says the 33 year-old Jody Fledderman. "It can really drain your resources and compromise the quality of your finished products if it isn't managed. Two years ago, when sales jumped 34 percent, the biggest challenge was just finding stuff. So we designed a color-coded retrieval system and tagged everything. Now the operators don't need to memorize each of the 500 parts we produce. They can tell where the part belongs by the tag color."

The shipping department also was updated and uses a bar-coded computerized picking system that was designed by the in-house MIS department. Each of Batesville Tool \& Die's 40 customers has its own containers, paper work and requirements, necessitating a sophisticated system to keep everything in order.

The constant banging of the shop's 40 presses makes conversation impossible. The company compensates for this by dotting the work areas with white marker boards covered with production updates and instructions. And more than a third of the employees use e-mail to keep in touch with each other and to ensure that the three shifts run smoothly. 
In the smaller press rooms, six employees tend 11 state-of-the-art metal-stamping machines. Each machine is computer-operated and employs numerous safety features to minimize accidents.

Employees must be well rounded and cross-trained because they each inspect and load parts, clean up and maintain the work space.

Even with the area's low unemployment rate, Batesville Tool \& Die has managed to find and keep good workers. Still, the company makes use of both technology and procedure to ensure that mistakes don't make it through to the customer.

"No one gets up in the morning and gets ready for work with the intention of making a mistake," Fledderman says. "But, after manufacturing 10,000 or more identical parts, human mistakes are a possibility. We have several measures in effect to make it easier on the employees, such as computerized camera vision systems that detect defects. The employee acts as a second check of the system to minimize the possibility of mistakes."

http://vnweb.hwwilsonweb.com/hww/jumpstart.jhtml?recid=0bc05f7a67b1790e43f188a0944caaa9d6db c413a9170af4823595a9cdbc1770392a347091f9599d\&fmt=H

Chappell, L. Visteon scores big win with Honda. Automotive News no. 6158 (July 25 2005) p. 3

Visteon Corp. has landed a major contract to supply instrument panel modules to Honda Motor Co. in North America.

Visteon, which was forced to seek a financial bailout from Ford Motor Co. this year, is moving deeper into business dealings with Honda, an automaker renowned for its stern scrutiny of suppliers.

Visteon will begin supplying the next-generation Acura MDX with the modules in 2007 in a contract that one industry forecasting firm estimates to be worth $\$ 30$ million a year.

The award also puts Visteon into an auspicious position: The MDX SUV platform is shared by the big-volume Honda Pilot SUV. Honda will begin awarding supplier contracts for that nameplate's next generation later this year.

While the MDX is on track for sales of about 70,000 a year, the Pilot is being forecast for 2008 model-year sales of 190,000 a year, according to CSM Worldwide, the Farmington Hills, Mich., forecasting firm. That's up from 128,158 U.S. sales in 2004.

A spokesman for Honda of America Manufacturing Inc. in Marysville, Ohio, which manages North American purchasing, declined to comment on future MDX plans or to discuss what will become of the suppliers to the current program.

Redesign in works

Visteon's module is part of an interior redesign and may combine parts currently supplied by Nippon Seiki Co. Ltd. of Japan and Intertec Systems LLC. Intertec is a North American 50-50 joint venture between Johnson Controls Inc. and Inoac Corp. of Japan. The Visteon component also may displace content currently made in-house by Honda.

Honda business is not new for Visteon. The Van Buren Township, Mich., company also supplies instrument cluster modules to the Honda Accord, which is built in Ohio. But the expansion of business 
is an indication that the parts giant is far from down and out. In May, Visteon unloaded 24 unprofitable factories and technical operations onto Ford, the company that spun it off in 2000 . The move shrinks Visteon's annual revenue from $\$ 18.9$ billion to $\$ 11.4$ billion.

Visteon could become profitable in 2006, says John Casesa, a Merrill Lynch analyst in New York. The company posted combined losses of $\$ 3.2$ billion from 2000 through the first quarter of 2005 .

A market leader

Paul Haelterman, CSM's director of market assessment, believes Visteon stands to gain ground in the coming months, specifically in the instrument cluster and cockpit business.

"People seem to be missing the fact that Visteon is a damn good cockpit supplier," Haelterman said. "They're one of the few companies in the segment that can extend their resources globally. They can operate on programs in North America, Asia and Europe at the same time."

As far as other opportunity in the segment, Visteon is watching as Collins \& Aikman Corp., its closest cockpit component competitor, claws its way through an uncertain bankruptcy. Collins \& Aikman of Troy, Mich., supplies approximately half of the instrument panel modules used by DaimlerChrysler and holds a 19 percent share of the North American market, according to CSM numbers.

CSM ranks Visteon No. 1 in the segment, with a 24 percent share of North America's cockpit market, based on the number of units. Collins \& Aikman filed for Chapter 11 bankruptcy protection in May and is currently re-examining existing contracts. 
http://www.post-trib.com/business/399534,mittal.article

\section{Mittal to reopen Gary plate mill}

May 24, 2007

\section{BY DANIELLE BRAFF Post-Tribune staff writer}

Mittal Steel USA announced Wednesday it will hire 200 to 250 workers to operate its plate mill in Gary, which is being reopened after remaining idle since the early 2000 s.

The target opening date is Sept. 3, said Pete Trinidad, vice president of U.S. Steelworkers Local 6787.

Trinidad, who returned Wednesday from a two-day meeting in Pittsburgh to discuss the plate mill's opening, said he's pleased with the decision to reopen the 160 -inch mill.

"Any time we're going to create 250 jobs for Northwest Indiana steel workers, we'll do whatever we can to help," Trinidad said.

The majority of the new hires will be selected from a pool of people Mittal already tested, Trinidad said.

The remainder will be drawn from WorkOne.

Jerome Davison, trustee of the local union, said the jobs being offered are high-paying.

"These are the types of jobs that can put meat and potatoes on the table," Davison said. "These are the jobs that build families."

The reopened mill will have the ability to produce plates up to 150 inches wide and up to 1,500 inches long.

It became idle after U.S. Steel stopped using it almost a decade ago. U.S. Steel swapped the mill with International Steel Group in exchange for the tin mill ISG owned in East Chicago. When Mittal Steel bought ISG, it regained ownership, and determined there was a new market for the product.

"Largely due to the strength of this market, plate demand has grown significantly for large-diameter line pipe, wind towers, transmission towers and tank cars," said Shelby Pixley, CEO of Mittal Plate USA.

Since the plate mill has been closed for such a significant amount of time, it will cost Mittal about $\$ 30$ million to $\$ 35$ million to get it up and running again, Trinidad said.

The costs will center around securing a supply of natural gas to run the mill and repairing some of the equipment currently in place.

Davison said it's important that Mittal take its time in restarting the plate mill so no steel workers get injured.

"Like anything, when you turn the lights off on an operation, you're talking massive amounts of machinery," Davison said.

"You have to make sure everything is safe for the workers to go back into it. It isn't something you could just walk in, flip the switch and go start. We all want to make good money, but we all want to go home alive." 
http://vnweb.hwwilsonweb.com/hww/jumpstart.jhtml?recid=0bc05f7a67b1790e43f188a0944caaa9d6db c413a9170af4fe31e313d45c89b7fa99b56c6a627027\&fmt=C

Brat, I. Indiana Town Woos Honda. Wall Street Journal (Eastern Edition) (June 22 2006) p. B1-2

.--- The residents of Greensburg, Indiana are actively courting Honda Motor Co. in a bid to win a carassembly plant for their town. Honda reported last month that it was going to build its next assembly plant in the Midwest, and Indiana and Ohio were the first states to confirm that the company had optioned land within their borders. Years ago, this region shunned Japan's auto industry mainly out of loyalty to General Motors Corp. Now, the Honda factory is a welcome prospect for the Midwest, which has been hard hit by the decline of the domestic auto industry. The new plant could employ as many as 1,500 workers and attract additional suppliers and related businesses to the state it chooses to call home

http://vnweb.hwwilsonweb.com/hww/jumpstart.jhtml?recid=0bc05f7a67b1790e43f188a0944caaa9d6db c413a9170af40d7d2deeb34a79d533324805c15d8d79\&fmt=C

Muller, J. A Savior From the East. Forbes v. 179 no. 12 (June 4 2007) p. 112-13

http://vnweb.hwwilsonweb.com/hww/jumpstart.jhtml?recid=0bc05f7a67b1790e43f188a0944caaa9d6db c413a9170af4bb86d42e6533e3576e4a8598dce9f810\&fmt=H

Seat maker follows Honda. Automotive News no. 6255 (May 14 2007) p. 30H, 30J

Honda's suppliers in Ohio, Michigan and Indiana plan to ratchet up production to meet more demand from the automaker when its new Greensburg, Ind., assembly plant begins producing the Honda Civic in 2008.

One such supplier is TS Tech North America Inc., which already makes seats, door liners and roof liners for other Honda plants. The company is building a \$17.5 million seating plant in New Castle, Ind., 
to supply Honda Manufacturing of Indiana LLC about 45 miles away in Greensburg.

TS Tech's factory will be about 210,000 square feet and employ about 300 workers. TS Tech has more than 60 percent of Honda's seat business in North America, said Scott Hepner, vice president of TS Tech's sales and purchasing division. The supplier provides seating to Honda's Marysville and East Liberty assembly plants in Ohio.

TS Tech considered expanding its Reynoldsburg factory, on the east side of Columbus, Ohio, but seating is such a large commodity that it made no sense to ship it 150 miles to Greensburg, Hepner said.

"Anytime you add more miles to the customer, it adds risk as well," Hepner said. "We had to consider that as well, especially in a just-in-time basis."

\section{An hour away}

When TS Tech learned that Honda would build its sixth North American assembly plant in Greensburg, "we started our own investigation," he said.

"We try to get about an hour away. That is safe for us," Hepner said. "That's a pretty short distance, yet far enough that we don't overlap in our hiring practices, so we don't exhaust the resources there."

TS Tech shows Honda the results of its internal investigations.

"We explain our criteria and our justification, and they help us get through to that final decision process," Hepner said.

The factory in New Castle will be the supplier's most innovative plant, combining the best features and processes from its plants around the world, Hepner says. TS Tech North America's parent company is TS Tech Co. Ltd. in Asaka, Japan. In North America, Honda is TS Tech's only automotive customer.

\section{A key supplier}

TS Tech is a key Honda supplier and a prime example of the supplier expansions under way among scores of Honda suppliers, not just those in Ohio, Indiana and Michigan, said Gary Mabrey, manager of the North American purchasing office for Honda of America Manufacturing Inc.

"Expansions are going on across North America," Mabrey said. "We help them to evaluate how to best meet our increased production, through expansion or relocation. We help them to look at all the different variables."

In the case of TS Tech, they make large, bulky items that are difficult and expensive to transport, he said. Honda will require seat shipments to its Greensburg assembly plant in sequence, Mabrey said.

"Not a lot will relocate, but there are companies evaluating such moves right now," Mabrey said in an interview at Honda's Greensburg plant site. "Because of our production increase, a significant number of our suppliers are expanding their existing plants, relocating, building new factories and adding new equipment."

Honda would not provide any specifics.

Honda's 154 suppliers in Ohio will be the main beneficiaries of the automaker's new Greensburg assembly plant. Honda expects the plant to have a $\$ 1.5$ billion impact on its supplier network, with its Ohio suppliers reaping nearly $\$ 1$ billion of that estimate in additional work.

\section{Lobbied hard}

The 154 Ohio suppliers employ about 18,700 Honda-dedicated workers. These suppliers are expected to add 1,000 jobs and invest $\$ 100$ million to prepare for the additional work.

The state of Ohio lobbied Honda hard for the new assembly plant that ultimately went to Indiana.

"Although we were disappointed that Honda chose Indiana, we also recognized that Ohio will still reap benefits and advantages with regard to employment in the supplier base, particularly in southwest Ohio," said Lee Fisher, Ohio's lieutenant governor.

State officials met with Honda executives in Marysville, Ohio, to discuss supplier opportunities, Fisher said, and now are "engaged actively with their suppliers around the state." ADDED MATERIAL

TS Tech

North American headquarters: Reynoldsburg, Ohio 
Parent company: TS Tech Co. Ltd. in Asaka, Japan

Share of Honda's North American seat business: $60 \%$

New plant:

* 210,000-square-foot operation in New Castle, Ind.

*\$17.5 million investment

* Will supply Honda's Greensburg, Ind., plant

* Will supply seats in-sequence

http://vnweb. hwwilsonweb.com/hww/jumpstart.jhtml?recid=0bc05f7a67b1790e43f188a0 944caaa9d6dbc413a9170af4d83b006cafa0ed1a77eef2b9ab2f28f3\&fmt $=\mathrm{H}$

Kisiel, R. New Honda plant is $\mathbf{\$ 1}$ billion gain for Ohio suppliers. Automotive News no. 6212 (July 17 2006) p. 4

Honda's 154 suppliers in Ohio will be the main beneficiaries of the automaker's assembly plant to be built in neighboring Indiana.

When the plant in Greensburg begins production in the fall of 2008 , Honda expects a $\$ 1.5$ billion impact on its supplier network.

Honda's suppliers in Ohio will receive nearly $\$ 1$ billion of that estimate in additional work, says Larry Jutte, senior vice president of Honda of America Manufacturing Inc.

Honda has told suppliers only that the factory will build a vehicle equipped with a four-cylinder engine.

The company's 154 Ohio suppliers employ about 18,700. They are expected to add 1,000 jobs and invest $\$ 100$ million to prepare for the additional work that the Greensburg plant will generate, Jutte says.

Honda has 16,000 employees in Ohio. The company builds the Accord sedan and coupe and the Acura TL in Marysville, Ohio. It builds the Civic sedan, Civic GX and Element in nearby East Liberty, Ohio.

\section{Project Zoom}

Construction of the Indiana plant begins this fall. The plant was given the code name Project Zoom because of how quickly Honda's site team chose the final site and how fast the automaker wants it built and producing vehicles.

Honda announced its site selection June 28.

The company says it may add a few suppliers to help feed the plant. But the automaker will ask less than a handful of suppliers to set up shop at the plant, Jutte says. Honda considered but rejected a supplier park encompassing the Greensburg factory.

"We looked at it in many ways, and we finally decided that wasn't the direction we were going to go," Jutte says. "We didn't see it as a huge positive -- from a financial standpoint -- impact to our facilities."

Honda also bucked the trend of building an assembly plant in Southern states. From the outset Honda wanted to remain close to its supplier base -- which is mostly in Ohio, Michigan and Indiana -and to its manufacturing operations in Ohio.

SET Enterprises Inc., an automotive metal-processing company, may be a prime candidate to pick up some Honda work. SET has plants in Ohio, Michigan, Illinois and Indiana. Its Indiana plant is only 20 miles from Greensburg.

SET now is a second-tier supplier to Honda on some products, processing material for Aisin U.S.A. Manufacturing Inc. SET would like to become a Honda Tier 1 supplier or get additional Tier 2 work.

SET and other nearby businesses are concerned about potentially losing good workers to the Honda plant in the sparsely populated community.

\section{No surprise}

Honda's decision to remain in the Midwest comes as no shock, says Steven Szakaly, an economist 
at the Center for Automotive Research in Ann Arbor, Mich.

"When you look at the issues some other companies have had in hiring people in the South, I don't think it's a surprise at all," he says. "There are some real problems in finding well-qualified individuals to work in these facilities."

Toyota, for example, is screening tens of thousands of people to hire just a few thousand workers, he says. Toyota is building an assembly plant in San Antonio to produce the Tundra full-sized pickup.

The Midwest, and Indiana in particular, has a history of manufacturing and has a large base of graduates from community colleges and technical schools well-equipped to work in industrial jobs, Szakaly says.

"The other major advantage: Transportation costs are so much lower when you already have this agglomeration of your industry in a certain area," he says. "It's pretty expensive to ship stuff down South if most of your suppliers are in the Midwest, especially if diesel prices keep going up."

The Greensburg plant is expected to employ about 2,000 at peak capacity and is designed to accommodate more than one model. It becomes Honda's sixth assembly plant in North America. It is expected to boost North American production capacity from 1.4 million units to more than 1.6 million in 2008.

ADDED MATERIAL

\section{Honda suppliers in Ohio}

Number: 154

Employment: 18,700

Annual sales: $\$ 4.7$ billion

Jobs they expect to gain from Indiana plant: 1,000

Revenue they expect to gain from Indiana plant: \$1 billion

http://vnweb.hwwilsonweb.com/hww/jumpstart.jhtml?recid=0bc05f7a67b1790e43f188a0944caaa9d6db c413a9170af4d8d5355e2c957a63320b5d39e87bcb7a\&fmt=H Kisiel, R. Supplier park partnership works for DCX. Automotive News no. 6215 (August 7 2006) p. $28 \mathrm{~F}$,

Automakers, in this age of just-in-time parts delivery, have been drawing their suppliers closer to their North American vehicle assembly plants. Nissan, Toyota, Ford and Mercedes-Benz all have vehicle assembly plants in North America where suppliers operate in adjacent buildings or so-called supplier parks. It's a model that has been tried periodically around the globe as well. But in a decade of trying, the industry has not proved that this kind of "plant of the future" has a future. DaimlerChrysler thinks it does. Honda rejected the concept.

Volkswagen AG, Ford Motor Co. and General Motors all have plants in Brazil with varying levels of supplier investment and assembly line involvement. DaimlerChrysler also had one in Brazil. Dana Corp. supplied a rolling chassis to DaimlerChrysler's Dodge Dakota pickup plant in Campo Largo, Brazil, for 19 months. The automaker closed the plant in early 2001. It was the victim of a faltering Brazilian economy. Now the Chrysler group is pushing that envelope in Toledo, Ohio. The DaimlerChrysler Toledo Supplier Park, a bold experiment and unique partnership involving the automaker and three Tier 1 suppliers, began producing the redesigned 2007 Jeep Wrangler in late July.

The Chrysler group surprised the industry in August 2004 when it told of plans to have three key suppliers invest in separate parts of a new Jeep Wrangler plant in Toledo. The suppliers were to own and operate the paint, body and chassis operations. The automaker heralded the model as the way of the future. Since then, one of the three suppliers, Ha- den International Inc., unexpectedly dropped out of the deal.

The Chrysler group scrambled to find a replacement for Haden, which had planned to own and 
operate the plant's paint shop. The automaker tapped Magna Steyr, an Austrian supplier and vehicle assembler that it knows well.

"I think any time you have something as groundbreaking as what we're trying to do, you are going to run into some hiccups," says Byron Green, vice president of manufacturing in Chrysler's truck and activity vehicle group assembly operations. "But it did not slow us down one bit. We couldn't be more pleased with what Magna has brought to the table in terms of the understanding of paint processes, and everything is working out fine."

\section{2 own facilities}

The Toledo Supplier Park will be operated by the Chrysler group and its three supplier partners: Magna Steyr, Kuka Group and Hyundai Mobis-owned Ohio Module Manufacturing Co. Kuka and Hyundai Mobis own their portions in the Toledo Supplier Park as planned. Magna Steyr will operate the paint shop, but DaimlerChrysler owns it.

"Magna Steyr brings to us a level of production expertise that we need because you really need that for someone taking over at that stage of the game," Green says. The key to the supplier park's success will be maintaining what has become "truly a partnership" and not the typical suppliercustomer relationship, Green says. "That's something we learned while visiting our Smart assembly plant in France," he says. The Chrysler group visited the Smart plant, in Hambach, France, shortly after revealing its bold plans. Eight suppliers build modules in that DaimlerChrysler plant and supply directly to the production line. Inventory is almost zero. The complex has 14 buildings that are shared with suppliers. Ironically, one on-site module supplier left the auto business, forcing Smart to find a replacement.

Representatives from the Chrysler group's purchasing and engineering teams that went to France did so mostly to see how the automaker and suppliers did business together.

\section{True partnership}

"It's a difficult endeavor to kind of pull off," Green says. "The take-away was the fact that it has to be a true partnership; you cannot have a dominant player. We were really trying to make it a series of equals working together to produce products." The uniqueness of this three-way partnership is that two of the suppliers have an equity stake in the project, saving the Chrysler group \$300 million for other endeavors. The three suppliers will funnel their technical expertise into Chrysler's assembly process, "and I think we can leverage each other's strengths and produce a really high-quality vehicle that the customer will really, really enjoy," Green says. Other carmakers have been curious about the Toledo Supplier Park and have even visited the site, Green says. "We've done some cross sharing in terms of visits to their sites and visits to our sites," Green says. "Everybody's curious about how it will work, can you make money at it, and how you will coordinate the operations to become one seamless event." Not everyone shares Chrysler's enthusiasm for a supplier park. Honda of America Manufacturing Inc., for example, considered but rejected a supplier park for its new \$550 million assembly plant in Greensburg, Ind. Honda may require a handful of suppliers to locate near the Greensburg plant, where Honda will build an undisclosed model with a fuel-efficient four-cylinder engine beginning in the fall of 2008. The plant will have an annual production capacity of 200,000 vehicles. "For the most part, the majority of our parts will come from our existing supply base in the Midwest," says Larry Jutte, general manager of Honda of America Manufacturing. "It's a little bit early to predict with exacting precision what we will do with our supply base versus do in-house. We are not considering supply parks and that whole concept."

\section{Honda rejects concept}

But Honda did examine the supplier park concept as it considered where to build its sixth automotive manufacturing plant in North America.

"We've studied this many different ways," Jutte says. "We didn't see it as a huge positive -- from a financial standpoint -- impact to our facilities. That equation is a pretty technical equation to talk about.

"We finally decided that wasn't the direction we were going to go, and it's not that we want to tell suppliers exactly what to do either. We want them to be strong and vibrant and profitable companies on their own." 
http://vnweb.hwwilsonweb.com/hww/jumpstart.jhtml?recid=0bc05f7a67b1790e43f188a0944caaa9d6dbc413a917 0af4da3d68a320c17fedd11c7da240fe5647\&fmt=H

McClenahen, J. S. Factory of the Future. Industry Week v. 256 no. 2 (February 2007) p. 21-2

Get a glimpse now of manufacturing tomorrow, IN DECATUR COUNTY, IND, A FACTORY of the future is now in the works. American Honda Motor Co. Inc. is building a $\$ 550$ million automobile manufacturing plant on 1,700 acres of land near Greensburg, 50 miles southeast of Indianapolis. The plant, for which construction was announced in June of last year, is slated to begin mass production of fuel-efficient, four-cylinder vehicles in the fall of 2008. The plant is expected to have a capacity of 200,000 vehicles and to employ some 2,000 people.

The Decatur County plant, Honda's sixth auto plant and 14th major plant overall in North America, will boost total North American auto production capacity for Honda to 1.6 million units, expand Honda's total North American employment to more than 37,000 people and increase North American capital investment to more than $\$ 9$ billion, according to the company. Honda says the new plant in Indiana will have the same type of New Manufacturing System that Honda has employed in its other U.S. and Canadian auto plants. The hallmark of the system is flexibility, which allows the automaker to produce different models quickly and efficiently. The major processes to be performed at the Decatur plant include stamping, welding, painting, plastic injection molding and assembly.

One of Honda's goals is to make the Indiana plant a "zero waste to landfill" factory, using advanced methods of energy and emission reduction. "Our goal to the environment is not based just on regulations or testing standards," said Akio Hamada, president of Honda of America Manufacturing Inc. and head of Honda's manufacturing operations in North America, when plans for the Indiana plant were announced last June. "Our goal is that this plant in Indiana will have the smallest environmental footprint of any Honda auto plant in North America."

"Honda's success in America has been based on our strong commitment to our customers," added Koichi Kondo, president of American Honda Motor Co. Inc and COO of Honda's North America Region operations. "We believe the great state of Indiana has what we need to continue thissuccess--an outstanding community of people, excellent transportation systems and the necessary infrastructure to support industry. It is an ideal location in the Midwest both for our network of parts suppliers and as a central location for all our customers across the country."

Meanwhile, this past year Dell Inc. was touting the accomplishments of a world-class factory of the future that opened in October 2005 near Win-ston-Salem, N.C. The 750,000-square-foot plant can produce one computer every 2.5 seconds--and produced its 1 millionth computer in May 2006.

In May 2006, the plant also exceeded its first-year hiring goal of 750 people. More than 1,000 had been hired.

The North Carolina plant, which cost more than $\$ 100$ million, includes a production layout that allows computers to be tested as its components and software are installed. This "instantaneous build-andtest" operation allows employees to identify and correct any problems immediately, rather than waiting until the product is completed, according to Dell.

ADDED MATERIAL

\section{SEEKING STELLAR PLANTS}

Is your facility an example of excellence in manufacturing? Do your manufacturing practices drive stellar performances? If so, then it is time to enter your manufacturing plant in INDUSTRYWEEK'S Best Plants competition. Nominations are now open for IW's annual salute to outstanding manufacturing facilities in North America. IW's Best Plants program recognizes manufacturing plants on the leading edge of efforts to improve competitiveness and encourages other manufacturers to adopt the worldclass practices and improvement strategies of the annual honorees.

Visit www.industryweek.com/research/bestplants/nomination.asp to nominate your plant or call Best Plants program coordinator Jill Jusko at 216-931-9311 for additional information.

\section{EMPLOYEE INVOLVEMENT}

Some manufacturing company employees would have every right to answer the question wit a resounding negative

They are wrong the $49 \%$ who responded to a recent informal INDUSTRYWEEK online poll, saying 
that employee satisfaction had never been measured at their companies. Twenty four percent of Those participating in the poll say employee satisfaction is measured at their companies once a year Nearly $19 \%$ say employee satisfaction is measured less than once a year just over $8 \%$ say their companies measure employee satisfaction more than once a year

The poll was posted during the first two weeks of November.

\section{ENERGY}

Dow Completes Cogeneration Purchase

ON DEC;. 1, 2003, Dow Chemical Co. completed its purchase of the Plaquemine Cogeneration Facility in Plaquemine, La., from a subsidiary of American Electric Power. The facility, which consists of four 170-megawatt gas-fired combustion turbine generators and a 200-megawatt steam turbine, has a capacity of 880 megawatts of power and 5 million pounds per hour of steam.

Dow had leased and operated the facility since it began commercial operations in March 2004.

"Purchasing the world-scale facility will enable Dow to generate power and steam via more energyefficient assets while decreasing our use of older, less-efficient equipment overtime" said John Dearborn, global vice president for energy, at the time of the purchase announcement. "With domestic natural gas at high and globally noncompetitive prices, this state-of-the-art cogeneration facility will help lower Dow's energy costs, while making our Plaquemine, La., manufacturing site more competitive." This spiral conveyor belt is part of Dell Inc.'s state-of-the-art 750,000-square-foot manufacturing plant near Winston-Salem, N.C.

http://vnweb.hwwilsonweb.com/hww/jumpstart.jhtml?recid=0bc05f7a67b1790e43f188a0944caaa9d6db c413a9170af4155fe6f159094fb610263a6a0a0b830e\&fmt=H

Miel, R. Honda seeks to mold long-term supplier ties. Automotive News no. 6226 (October 232006 ) p.

WINDSOR, Ontario -- It has been three years since Unique Tool \& Gauge Inc. was invited to join other tool makers at a meeting with Honda of America Manufacturing Inc.

Honda told the suppliers that as part of its co-management program with tool and die shops, it was looking for a few good companies it could establish long-term partnerships with. These would be companies that could bring new insights and expertise to Honda while benefiting from increased business with the automaker.

Darcy King, vice president of sales and engineering for family-owned Unique Tool, says he can remember looking around at the other companies in the room and thinking it would be amazing if Unique Tool somehow could be the last business standing.

Now the 70-employee company is one of two injection-mold makers that are part of Honda's comanagement program. And King is seeing the benefits that Honda promised.

"We've been saying for years, give us a voice and we can help you," he says. "They gave us a voice."

The co-management system with Honda Motor Co.'s North American manufacturing branch was not just some happy coincidence.

Unique Tool already had a specific, long-term strategy for growth with Asian automakers and has invested in technology and capabilities to help it compete on any job.

"They weren't just looking for the biggest companies or the smallest companies," says Unique Tool President Robert King.

"They wanted somebody with an ideology that matched what they were doing. It gets back to finding the fit and the product profile that they're looking for."

\section{Changing industry}

Robert King, Darcy King's father, started Unique Tool more than 20 years ago. The company did most of its business with the auto industry. He has had Honda as a customer for nearly a decade, he says.

During that same time, mold makers working with the auto industry have had to keep up with a series 
of changes. Automakers looking for ways to cut costs have eliminated much of their in-house plastics expertise. That means molders and mold makers have had to take on more design and engineering.

Customers also have demanded faster product development time, requiring mold makers to reduce production cycles to weeks rather than months.

And competition from low-cost countries has forced tool makers to tweak their own operations, bringing in more automation while using skilled labor strategically.

"You have to be aggressive and plan," Darcy King says.

Unique Tool adjusted to meet the changes and provide North American automakers with the tools they needed. But at the same time, it had to put extensive effort into proving its abilities to Asian carmakers.

\section{'You have to commit'}

Says King: "Relationships don't just happen. You have to commit yourself. And commit every aspect of your business, not just your sales team."

Unique Tool has added two carbon cutting machines capable of operating without workers being present. But the company also has skilled laborers who can handle the delicate hand-finishing of tools.

Unique Tool learned how to bring more engineering in-house and invested in software and design, while also working closely with customers to smooth new-product launches.

The second injection-mold maker in Honda's co-management program also has invested in upgrades. Rapid Die \& Engineering Inc., of Grand Rapids, Mich., has supplied Honda for more than 10 years, says Rapid Die President Chris Jones. The 85-employee company opened in 1946. The Jones family has owned it since the 1970s.

Rapid Die has invested in new equipment and an 8,600-square-foot expansion that has boosted its production speed, Jones says. Having a long-term commitment from Honda helped support the decision to invest, he says.

The tool maker still must deliver on price and quality standards continually. No one gets a free ride.

But there are other long-term benefits beyond a contract. For example, Honda helped Unique Tool streamline its production and even fine-tune its business plan. Improvements such as those will support the tool makers and their entire range of customers, not just Honda, Darcy King says.

He adds: "Some of our best customers -- even outside of (Honda) -- are the ones that listen." ADDED MATERIAL

Rhoda Miel (2)

Unique Tool \& Gauge's Darcy King comments on working with Honda: "Give us a voice and we can help you. They gave us a voice."

An employee at Unique Tool works on a mold. The Canadian company is a partner in a Honda program that was created to establish long-term relationships with select tool and die shops.

http://vnweb.hwwilsonweb.com/hww/jumpstart.jhtml?recid=0bc05f7a67b1790e43f188a0944caaa9d6db c413a9170af4522a82f03cc19d9279cca550770367e7\&fmt=P Bruns, A. Honda's Sure Thing. Site Selection v. 51 no. 5 (September 2006) p. 612, 614-15 (ANANTH"S ALSO)

During his first weeks as director of the U.S. Office of Management and Budget under President George W. Bush, Indiana Gov. Mitch Daniels had to turn around budget numbers with preternatural speed: The 2000 general election dispute had delayed staff appointments, but it had not delayed budget deadlines.

So when he first heard about Honda's "Project Zoom" -- the assembly plant component of a multistate facilities build-out announced in May by Honda of America -- the site search's speed and the pressure that accompanied it were not exactly alarming.

"I received the first phone call [asking] whether I could be available within a week or two," Daniels tells Site Selection. "I said, 'No, I'll be at a place of your choosing tomorrow morning.' I took a plane to a private location, and while there I called our Secretary of Commerce [Michael Maurer] cell to cell and 
asked him to fly the following day to meet with Honda, and that occurred too."

In the parlance of Daniels' old poker buddies at Princeton, that's called raising the stakes. But given the pace of projects just since January from companies like Pfizer, FedEx, Nestle and Toyota, it wasn't a case of all-in.

Daniels, a former president of Eli Lilly and Co.'s North American operations, has put his business acumen to good use in his first 18 months in office: " 1 have sat where they sit on making investment decisions," he says of corporate prospects. And upping the ante accomplished what it's supposed to: getting their attention.

Four months after that first call, the dignitaries assembled for the 2,000-job announcement in downtown Greensburg, which beat out sites in Van Wert, Ohio; Fithian, III.; and two other nearby locations in Decatur Co., Ind., where the land options were not as easy to assemble into a winning hand.

\section{Get Your Money Back}

The card playing doesn't stop there. Key to making the \$550-million Honda project happen is a \$10million contribution from the City of Lawrenceburg, nestled on the Ohio River 50 minutes from Greensburg, to the incentive package. Having caught up with the infrastructure deficit that the first wave of riverboat gaming tourism wrought, the forward-thinking leaders of Lawrenceburg decided some time ago to devote a significant portion of gaming receipts to helping their region at large. The $\$ 10$ million is the town's Year One investment, but Lawrenceburg officials may see Honda-related development as a good target for Years Two and Three as well. Does Daniels think this arrangement provides a new model for collaboration between two frequently warring sides of economic development?

"Yes, I do," he says from RV One, his customized 2001 Beaver Patriot Thunder RV from Monaco Coach of Oregon, one of many RV manufacturers with plants in Indiana. Daniels has just boarded from a \$16-million expansion announcement by automotive supplier Madison Precision Products in the southeast Indiana town of Madison, not far from Greensburg. "Coincidentally, I'm going to Lawrenceburg to talk about this very subject," he says of the incentives boost. He calls the city's commitment "very material" to the process.

"Obviously a lot of those receipts are generated by people across the region, so it makes sense to return it to the region," says Don Schilling, CEO of Decatur County Rural Electric Member Cooperative and also board president of the Greensburg-Decatur County Economic Development Corp.

But Daniels is clear: Incentives were "the very last thing we talked about with Honda. Honda was very modest in its requests, and the only incentives they were interested in were funds for infrastructure. The accurate number for Indiana's investment is $\$ 80$ million, and while we're at it we're going to build additional infrastructure that Honda doesn't need at all."

\section{Assets in Gear}

For Decatur Co. REMC, the last stage of this site selection was lightning fast, but the process began long ago.

"We started working to develop an industrial park on 260 acres [105 hectares] about two and a half years ago, which is now part of the Honda site," says Schilling. "About a year ago, we were able to get options on that acreage and the adjacent 180 acres [73 hectares] of land. From that point, the EDC, with the help of Executive Director Vicki Kellerman, was able to put a package together and apply for the new state program Shovel-Ready Sites. A little before we put in the application, we learned of a company looking at a site east of Greensburg. They were not successful in getting all the options they needed there. They went to a second site west of Greensburg and had similar results. We decided to offer our acres, they took it, and were able to assemble their 1,700-acre [688-hectare] site from that point."

Power supplier Hoosier Energy is constructing two 138-kilowatt transmission lines to the site, with one more to come over the next year to serve the area. The total investment by Hoosier Energy and Decatur Co. REMC will be around $\$ 25$ million.

Other hard infrastructure is rising to the occasion too: The CIND line, a short line railroad operated by RailAmerica, will serve the new Honda project.

"The actual assembly plant will rest square in the middle of our mainline, so we will relocate our mainline to accommodate the plant and we will be the main carrier serving the plant out of Cincinnati 
and Indianapolis," says Tom Owen, senior vice president of business development and corporate strategy for RailAmerica, owner of 42 short lines in North America. Serving a plant of this size will involve a large amount of traffic interchange with Class I partners CSX and Norfolk Southern.

RailAmerica's punch list includes an upgrade of parts of the main track that can't handle loads of $286,000 \mathrm{lbs}$., as well as bridge construction and some tie replacement.

\section{Pleasant Surprises}

Daniels likes direct. That's why he leaves the phone to climb down from the RV at the general store in rural Cross Plains, Ind., not far from Canaan and China. Once back on the line, he reports that several men in general construction just told him they're excited by the Honda project because they think more homes will be built. Industrial prospects are anything but waning, with three supplier expansions already and just as many scouting the area.

"More rapidly than I would have thought, the possibility of knock-on effects may be showing up," he says. "We've seen the same with Toyota adding 1,000 jobs in Lafayette."

Asked to assess the influence of certain initiatives on this deal and others, Daniels says yes, his \$12billion "Major Moves" transportation infrastructure plan was "unquestionably" a factor. Moving to singlefactor corporate taxation is also a big deal, he says.

"Indiana has had a three-part basis, which meant the more investment and employees you had in the state, the higher your taxes were," he says. "There must have been logic to that, but I couldn't find it."

Neither could companies. Daniels recounts his conversations with Toyota officials prior to their Lafayette announcement, which like Honda carries a modest state incentives package, amounting to $\$ 14$ million.

"Toyota said an admirable thing to me," says Daniels. "They said, 'Listen, more important to us than any incentives is that eventually you move to single-factor taxation, so we no longer have a disincentive to invest here.' At the time, I said we were working on that, but to my surprise we did get it through this legislature. And Toyota will forego some of the small package we had agreed to."

Having its own fiscal house in order has also helped Indiana, something which has surprised even a former OMB director. As its debt ratings rise, the state has its first balanced budget in eight years, and is also setting things straight fiscally with its school systems.

"I probably underestimated the attention some would pay to this," says Daniels. "If people believe a balanced budget and a stronger fiscal position reduces the possibility of tax increases, they'd be exactly right as far as we're concerned."

\section{Aligned Visions}

As for future development around the new Honda site, the Ohio-Indiana-Kentucky momentum in the logistics and automotive sectors is undeniable. Rail America's Tom Owen says of the site's immediate surroundings, "There is a lot of soybean and corn growing out there on either side of our track, so there is abundant land."

Don Schilling concurs: "It appears that there's some understanding that that corridor out 1-74 is a prime area for additional development."

Will the area be ready? Do Hoosiers know how to shoot free throws?

"It has every possibility," says Gov. Daniels of the region's potential to mirror the fertile crescent of facilities that Honda already has worked to maximal productivity in central Ohio -- another state reveling in recently upgraded bond ratings. But Indiana already can point to a fertile crescent of its own.

"As you look at the large Toyota plant in Princeton, clearly it had that sort of effect on other communities there, so we already see the first signs that could happen here," Daniels says. "And we won't just sit back and hope for the best."

ADDED MATERIAL

ADAM BRUNS

adam.bruns@conway.com

Honda will locate on 1,700 acres (688 hectares) in Greensburg, some 50 minutes southeast of Indianapolis. According to multiple published reports, offers for the property came in at $\mathbf{1 7 5}$ percent of assessed value, including a \$6,000 signing bonus. Photo: American Honda Motor Co., Inc.

Greensburg, Ind., Mayor Frank Manus and Indiana Gov. Mitch Daniels mark the words of Koichi Kondo, COO of Honda's North American region and president \& CEO of American Honda, in announcing the 
location of Honda's new \$400-million assembly plant. The company had announced its intent to build a plant on May 16. The Indiana plant coincides with Honda expansion projects in its productive Ohio portfolio, Ontario, Georgia and Ilion, as part of its "2010 Vision" for North America.

\section{Hoosier Honda \\ BY DOUGLAS BRINKLEY \\ Word Count: 950}

How things have changed. In the mid-1970s, anybody found driving a Japanese car in Michigan was in danger of ending up with a tire slashed or a door keyed. Today, mention one of the Big Three U.S. auto-makers -- GM, Ford or DaimlerChrysler -- at a blue-collar Midwestern honky-tonk and you'll hear groans. Everybody in the Midwest these days is begging Honda to come into their hometown. It is no longer viewed as a "Japanese" company, but a "pro-American-worker" corporation flush with jobs, jobs, jobs.

Earlier this summer, Honda announced its plans to open a $\$ 550$ million plant in Greensburg, ...

WSJ.com 7/18/06

\section{Honda's Plant Plan Stands In Contrast to Detroit BY NORIHIKO SHIROUZU \\ Word Count: 557 | Companies Featured in This Article: Honda Motor, Toyota Motor, General Motors, Ford Motor}

Honda Motor Co. 's selection of an Indiana town to build a \$550 million passenger-car plant, its sixth assembly factory in North America, highlights the ambitious growth strategies of Asia-based auto makers while their Detroit competitors move to cut jobs and close plants.

Koichi Kondo, a senior Honda executive, said yesterday that the Tokyo-based auto maker has chosen the southeastern Indiana town of Greensburg, 50 miles southeast of Indianapolis, as a site to produce "fuel-efficient" cars starting in the fall of 2008. He said the plant will eventually have capacity to manufacture 200,000 vehicles a year and hire 2,000 workers.

WSJ.com 6/29/06

June 20, 2007

June 20, 2007

Jobless rate dips to $4.5 \%$ in Indiana 
May's rate lowest since 2001; 5,000 jobs were added in past year

Star report - Indy star. com

Indiana has added more than 5,000 jobs in the past year, and unemployment fell to 4.5 percent in May, the lowest rate since September 2001, according to government data released Tuesday.

A year ago, the state's unemployment rate was 5.1 percent.

Some observers say the economy may be starting to rebound -- even the hard-hit manufacturing sector that has seen large layoffs at auto-supply plants.

"We're seeing it in all sectors -- in manufacturing, HR, finance," said Teresa Hinkle, regional director in Central Indiana for staffing company Manpower, which helps companies find temporary and permanent workers.

Hinkle said business has improved noticeably from a steep falloff two years ago.

When Manpower surveyed employers recently, 46 percent said they planned to increase hiring from July to September, compared with 18 percent in the previous quarter.

In some cases, employers who cut too many jobs are rehiring former workers, Hinkle said. Other employers are expanding.

About 5,200 more jobs were reported in May from a year ago, according to the Indiana Department of Workforce Development.

Overall, manufacturing continued to suffer, dropping 9,400 jobs in the past year. But some major manufacturers -such as Cummins, Rolls-Royce and Pfizer -- are adding jobs.

From January through May, the overall number of jobs has risen by 4,300 statewide. A year ago, the state lost 3,300 jobs during the same period.

Democrats, however, pointed to a report from the Bureau of Labor Statistics on Tuesday that showed Indiana lost 2,100 jobs from April to May, the fourth-highest decline behind Florida, Michigan and Wisconsin.

"How many more months of lackluster results do we have to endure before Mitch Daniels admits that his 'economic hot streak' talking points don't match up with Indiana's economic reality?" asked Indiana Democratic Party Chairman Dan Parker in a news release.

Nathan Feltman, secretary of commerce and president of the Indiana Economic Development Corp., stressed the decline in the unemployment rate.

"It's good news, obviously," he said.

Feltman said results of deals the state has made to attract new employers, such as Honda and Nestle, won't show up in statistics for another year or two.

"All the deals we've been working on the past two years -- most of those jobs have yet to come online," he said. 
Honda of America Manufacturing Inc.

http://galenet.galegroup.com search: Honda

24000 Honda Pkwy.

Marysville, Ohio

43040-8612

United States

Tel: $\quad$ (937) 642-5000

Fax: (937)644-6543

\section{Business}

Manufacturing: Motorcycle and automobile manufacturing.

Parent

American Honda Motor Company Inc.

Ult. Parent

Honda Motor Company Ltd.

\section{SIC Codes}

3711 - Motor Vehicles And Car Bodies

3751 - Motorcycles, Bicycles And Parts

NAICS Codes

336111 - Automobile Manufacturing

336991 - Motorcycle, Bicycle, and Parts Manufacturing

Annual Sales

$\$ 5,090.00$ M Sales, Estimate

Employees

13,000, Company Information

Sales/Employees

$\$ 391,538.00$

Year Founded

1979

Fiscal Year

Mar 31, 2006

Features

Exporter, Private Subsidiary, Headquarters Location

URL

http://www.ohio.honda.com

http://www.ohio.honda.com

3. Honda of America Manufacturing Inc./Marysville

Location: Marysville, Ohio

Products: Honda Accord; Acura TL, RDX

2006 production: 437,017

Annual capacity: 440,000

Opened: 1982 
Employees: 5,300

Top executive: Akio Hamada, CEO

Fast fact: One of the most integrated auto plants in North America, it houses stamping, weld, paint, plastic injection molding and assembly.

\section{Officers}

Takeo Fukui - Chief Executive Officer and President

Document Number

DC130926

In early 2005, overseas automakers continued to gain U.S. market share. Sales of cars and light trucks in April 2005 alone numbered 1,504,332, an increase of 5.7 percent over the year before. However, GM and Ford still lost market share, as did U.S. automakers overall. While the Chrysler Group showed substantial sales increases, and General Motors and Ford's new cars were selling well, overall the Big Three U.S. auto companies lost market share, bringing them to about 43 percent of the domestic market. Japanese companies were gaining rapidly. Nissan North America showed a gain of almost 32 percent, Toyota Motor Sales U.S.A. increased sales by almost 26 percent, and American Honda Motor Co. climbed 18 percent.

Automotive News, Oct 3, 2005 v80 i6169 p22 


\section{Honda considers on-site suppliers.}

(Honda of America Manufacturing Inc.)

Lindsay Chappell

Full Text: COPYRIGHT 2005 Crain Communications, Inc.

Byline: Lindsay Chappell

Rising transportation costs could push Honda of America Manufacturing Inc. to move some North American suppliers closer to its assembly plants here and in Marysville, Ohio.

Larry Jutte, Honda's senior vice president for procurement in North America, says that as trucking costs rise, the idea of moving some suppliers closer to Honda's property "is beginning to make more financial sense."

Trucking costs have risen dramatically in recent years, largely because of higher diesel fuel prices. Last week diesel prices hovered around $\$ 2.80$ a gallon, up 79 cents, or about 39 percent, from a year ago, according to the U.S. Department of Energy.

"We're studying a lot of things from a logistics point of view," Jutte says. "There are certain subassemblies that we could move closer to us or even bring inside."

If so, Honda would be following the same path as its two closest rivals, Nissan North America Inc. and Toyota Motor Manufacturing North America Inc. Nissan has moved a number of suppliers onto its assembly plant property in both Canton, Miss., and Smyrna, Tenn., over the past three years.

Toyota is constructing a pickup plant in San Antonio that also will incorporate on-site component producers.

Both competitors did so, they said, to reduce transportation costs, eliminate part handling and cut warehousing costs. Nissan has supplier employees assembling part modules inside its Smyrna plant.

Until now, Honda has left its North American supply chain to operate much as it has for two decades.

About 600 parts companies now ship parts to assembly plants in Ohio, Alabama and Ontario.

And unlike its Big 3 competitors, Honda has been reluctant to turn over module subassembly work to outside suppliers.

"We never jumped on that bandwagon of outsourcing entire modules," Jutte says.

But Honda now is considering ideas for future vehicle parts, he adds. "In some cases, we'd like to eliminate subassemblies altogether, and we're already beginning to do some of that."

The redesigned Civic that debuted in September has an engine harness that comes assembled and a relay box that is molded into place.

Jutte declined to say which suppliers might be considered for relocation. But he said improving employee safety also will be a factor in the decisions about where parts are subassembled.

"If we can reduce the stress and strain on our associates and improve safety by making a part differently," he says, "then it might make more sense to assemble it outside in the future." 


\section{CAPTION(S):}

Larry Jutte: Moving suppliers closer to Honda's assembly plants makes good financial sense.

Article A137240985

Automotive News, Oct 23, 2006 v81 i6226 p20D

Honda seeks to mold long-term supplier ties; 2 companies seek voice in management - and get it.

(Unique Tool \& Gauge Inc.)

Rhoda Miel

Full Text: COPYRIGHT 2006 Crain Communications, Inc.

Byline: Rhoda Miel

It has been three years since Unique Tool \& Gauge Inc. was invited to join other tool makers at a meeting with Honda of America Manufacturing Inc.

Honda told the suppliers that as part of its co-management program with tool and die shops, it was looking for a few good companies it could establish long-term partnerships with. These would be companies that could bring new insights and expertise to Honda while benefiting from increased business with the automaker.

Darcy King, vice president of sales and engineering for family-owned Unique Tool, says he can remember looking around at the other companies in the room and thinking it would be amazing if Unique Tool somehow could be the last business standing.

Now the 70-employee company is one of two injection-mold makers that are part of Honda's co-management program. And King is seeing the benefits that Honda promised.

"We've been saying for years, give us a voice and we can help you," he says. "They gave us a voice."

The co-management system with Honda Motor Co.'s North American manufacturing branch was not just some happy coincidence.

Unique Tool already had a specific, long-term strategy for growth with Asian automakers and has invested in technology and capabilities to help it compete on any job.

"They weren't just looking for the biggest companies or the smallest companies," says Unique Tool President Robert King.

"They wanted somebody with an ideology that matched what they were doing. It gets back to finding the fit and the product profile that they're looking for."

Changing industry

Robert King, Darcy King's father, started Unique Tool more than 20 years ago. The company did most of its business with the auto industry. He has had Honda as a customer for nearly a decade, he says. 
During that same time, mold makers working with the auto industry have had to keep up with a series of changes. Automakers looking for ways to cut costs have eliminated much of their in-house plastics expertise. That means molders and mold makers have had to take on more design and engineering.

Customers also have demanded faster product development time, requiring mold makers to reduce production cycles to weeks rather than months.

And competition from low-cost countries has forced tool makers to tweak their own operations, bringing in more automation while using skilled labor strategically.

"You have to be aggressive and plan," Darcy King says.

Unique Tool adjusted to meet the changes and provide North American automakers with the tools they needed. But at the same time, it had to put extensive effort into proving its abilities to Asian carmakers.

'You have to commit'

Says King: "Relationships don't just happen. You have to commit yourself. And commit every aspect of your business, not just your sales team."

Unique Tool has added two carbon cutting machines capable of operating without workers being present. But the company also has skilled laborers who can handle the delicate hand-finishing of tools.

Unique Tool learned how to bring more engineering in-house and invested in software and design, while also working closely with customers to smooth new-product launches.

The second injection-mold maker in Honda's co-management program also has invested in upgrades. Rapid Die \& Engineering Inc., of Grand Rapids, Mich., has supplied Honda for more than 10 years, says Rapid Die President Chris Jones. The 85-employee company opened in 1946. The Jones family has owned it since the 1970s.

Rapid Die has invested in new equipment and an 8,600-square-foot expansion that has boosted its production speed, Jones says. Having a long-term commitment from Honda helped support the decision to invest, he says.

The tool maker still must deliver on price and quality standards continually. No one gets a free ride.

But there are other long-term benefits beyond a contract. For example, Honda helped Unique Tool streamline its production and even fine-tune its business plan. Improvements such as those will support the tool makers and their entire range of customers, not just Honda, Darcy King says.

He adds: "Some of our best customers - even outside of (Honda) - are the ones that listen."

\section{CAPTION(S):}

Unique Tool \& Gauge's Darcy King comments on working with Honda: "Give us a voice and we can help you. They gave us a voice." * An employee at Unique Tool works on a mold. The Canadian company is a partner in a Honda program that was created to establish long-term relationships with select tool and die shops.

Article A153349531

Ward's Auto World, July 1, 2005 v7 i41 pNA

Honda Asserts NA Purchasing Independence. 
(Honda of America Mfg. Inc.)(North America)

Tom Murphy

Full Text: COPYRIGHT 2005 PRIMEDIA Business Magazines \& Media Inc. All rights reserved. Byline: Tom Murphy

It takes a lot to rattle Larry Jutte, a soft-spoken Midwesterner who grew up in Ohio farm country and rarely finds reason to raise his voice.

But the senior vice president-procurement for Honda of America Mfg. Inc. shows slight agitation - and amusement - upon hearing that Ford Motor Co. purchasing chief Tony Brown suggests Ward's interview Honda's Japanese honchos to fully understand the scope of its global purchasing organization.

Brown says Honda's U.S. procurement team, led by Jutte, "may be competent, but the real decisions get made in Japan."

Jutte begs to differ. His organization includes 1,400 purchasing agents in North America. In Marysville, OH, Jutte has 200 buyers handling quality, cost, delivery and logistics, tied in with Honda research and development "everything it takes to get that product sourced, qualified and quality-ready for mass production."

A smile comes to Jutte's face as he responds to Brown's comment, speaking softly at first, but finishing with an uncharacteristic flurry of emotion.

"You can tell Tony Brown that I've been there, I've seen it," he says, his voice rising. "There's a whole bunch of people there doing that kind of work, and they're working with the R\&D guys with exclusive models that are only made in North America and Japan's not involved with it!"

Jutte refers to a global vehicle program Honda will launch "in a few years" that will be led by the Marysville staff, with collaboration from Japan and other regions.

"Everyone in the company understands because the (sales) volume is in North America, that whatever is good for North America is probably good for Honda globally," Jutte says. "This team will communicate globally to be able to make the right decisions. It'll be a team decision."

Jutte says Japan offers ideas but does not dictate to his organization. "Thailand has ideas. China has ideas. The U.K. has ideas. It's all of those ideas that make Honda collectively better than any individual country or any individual in the company."

Honda views suppliers as part of the team. Although Detroit is eager to source parts for the U.S. from low-cost regions, Jutte says Honda remains wedded to the notion that parts should be sourced locally.

The challenge is to find U.S. suppliers that are price-competitive. Jutte refers to ADAC Plastics Inc. of Grand Rapids, MI, a supplier of the distinctive inner door handles on the new Ridgeline truck.

"They are a good company," Jutte says. ADAC's original quote for the Ridgeline was the best, even on a global basis. That wasn't quite good enough for Honda.

"We went in and by working with them on tooling, on cycle times, on parts procurement, on all aspects of doing business, we were able to reduce that original quote by almost 15\%," Jutte says. "That made them that much more competitive. Not just for Honda, but for anyone they're doing business with."

Even Ford and Tony Brown. 
Honda purchasing - by the numbers

\$13.6 billion North American purchasing budget (autos and motorcycles)

600 suppliers in North America

1,400 buyers in North America, including 900 in Ohio

Article A134694600

Automotive News, May 28, 2007 v81 i6257 p18 
Supplier loses Honda work, will close Ala. plant.(Suppliers)(T\&WA Inc.)(Honda Manufacturing of Alabama L.L.C.)(Alabama )(Brief article)

April Wortham

Full Text: COPYRIGHT 2007 Crain Communications, Inc.

Byline: April Wortham

A minority supplier that found itself on the losing end of Mercedes-Benz's Alabama expansion two years ago is now being cut loose there by Honda.

T\&WA Inc., a supplier of preassembled tire and wheel modules, will close its Birmingham plant and lay off 51 employees at the end of June.

The decision comes after Honda Manufacturing of Alabama LLC opted not to renew its contract with T\&WA, said Byron Meyer, president of the Louisville, Ky., supplier.

Honda had little to say about the change except that, during the past few years, it has been developing proprietary technologies for tire and wheel subassembly. Honda's Lincoln, Ala., plant produces the Pilot crossover and Odyssey minivan.

Picking up the Honda contract will be Gulf Shore Assemblies, a sister company of Great Lakes Assemblies in East Liberty, Ohio. Great Lakes and Gulf Shore Assemblies are joint ventures of Midwest Express Inc., a Honda affiliate, and TAG Holdings LLC.

Great Lakes, also a certified minority supplier, supplies tire and wheel assemblies for the Honda Accord, Civic and Element and the Acura TL. A new plant is under construction on the Honda campus in Lincoln, said plant spokesman Ted Pratt.

Meyer said T\&WA will continue to supply Honda until the new supplier takes over in July. T\&WA's Birmingham plant, which served Honda exclusively, then will be sold, he said.

T\&WA began supplying Honda in 2001. At that time, it also pre-assembled tire and wheel modules for MercedesBenz U.S. International Inc. in Vance, Ala. But when Mercedes asked T\&WA to invest in a new plant closer to Vance in time for its 2005 expansion, T\&WA said it couldn't comply.

To qualify as a certified minority supplier, at least 51 percent of a company's equity must be held by members of a racial minority. Borrowing money or issuing stock to fund the Mercedes investment would have watered down T\&WA's minority ownership stake.

Meyer said the Lincoln plant was T\&WA's only Honda contract.

Article A164286869

Automotive News, May 14, 2007 v81 i6255 p30H

New engine plant.(New American Manufacturers)(Honda Motor Company Ltd.)(Brief article)

Full Text: COPYRIGHT 2007 Crain Communications, Inc.

The skeleton of Honda's engine plant in Alliston, Ontario, is beginning to take shape. The factory is adjacent to 
Honda of Canada Manufacturing's two plants that assemble the Honda Civic and Ridgeline and Acura MDX and CSX. The engine plant will open in 2008 and produce 200,000 four-cylinder engines for Honda and Acura vehicles. Honda is spending \$140 million to build the plant. Alliston is about 40 miles north of Toronto.

Article A163523750- 
Newest wave of parts suppliers smaller, 'just in time' production (ANANTH) By KEITH ROYSDON

kroysdon@muncie.gannett.com

sтormenat:Post Comment

MUNCIE -- Across I ndiana, communities are scrambling to land the new wave of automotive assembly plants, and companies are beefing up their auto parts manufacturing operations. That activity is typical of the rapid changes in the supply chain.

"It's what localities are hoping for," said Susan Helper of Case Western Reserve University of Cleveland, Ohio, when asked about auto parts suppliers springing up in the wake of Honda's Greensburg assembly plant.

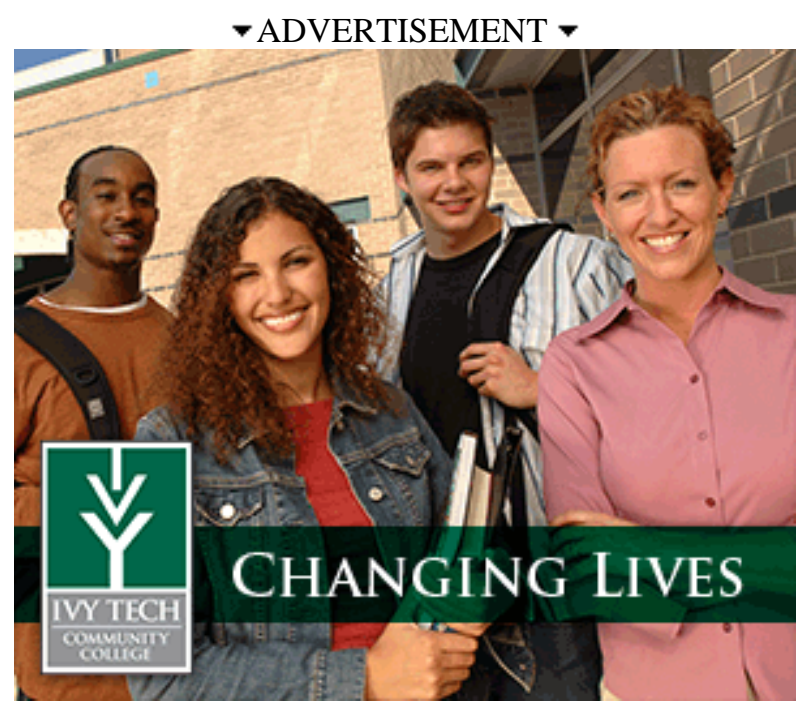

"Honda in particular wants suppliers nearby, so people will locate parts plants right nearby," added Helper, an automotive industry expert.

Helper's comments were made in anticipation of Friday's announcement of a new auto parts plant in New Castle that would supply Honda. TS Tech plans to employ 300 people in its $\$ 10$ million plant.

While long-standing plants like Muncie's BorgWarner -- with its contract to supply transfer cases to struggling automaker Ford -- is due to close no later than spring 2009, companies with contracts with Honda -like TS Tech, Keihin Aircon of Muncie and Tamasco LLC of Randolph County -- are seeing increased business, and that means expansion and new hiring. - investigate these companies web sites.

Smaller, leaner plants might be the future. Industry experts say that "transplant" automakers like Honda and Toyota typically have more parts contracts with smaller suppliers. The companies follow a "just in time" philosophy to avoid stockpiling parts before assembly. They order parts from suppliers within a small radius, and the parts arrive just in time for the cars to be assembled.

In an interview with Inbound Logistics, Dick Jenning of auto parts supplier Ryder said, "If an automaker uses a supplier located $\mathbf{5 0}$ miles from its plant, the risk is minimal. But if the supplier is 2,000 miles away, the risk of supply disruption or delay is greater."

The magazine noted that at some production facilities, a work stoppage can cost $\$ 10,000$ to $\$ 100,000$ a minute.

"If the idea of 'just in time' is a good thing, we won't see massive 20,000-person plants like we used to see in the 1950s," Helper said. "But whether the size turns out to be 100 or 800 , those are going to be more typical numbers."

The new parts suppliers could also change the mix of imported versus domestic parts and the perception of foreign-made versus American-made vehicles. If that change 
occurred, it would reverse a trend that has seen the percentage of the U.S. parts business that stems from U.S.-made parts shrink from 70 percent in 1997 to 41 percent in 2005. Contact news reporter Keith Roysdon at 213-5828

From http://www.expansionmanagement.com/Industryspotlights/Automotive/18713

QTR Inc. to Open New Facility in Evansville, Indiana

EVANSVILLE, Ind. (May 25, 2007) - With a total investment of $\$ 3.7$ million, the expansion included an additional twin-screw production line, improved blending and material handling capabilities.

\section{[ 5/25/2007 ] By: NEWS BRIEFS}

QTR, Inc. recently celebrated the grand opening of its newest facility in Evansville, Ind. The company built a state-of-the-art facility adjacent to its existing manufacturing facility. With a total investment of \$3.7 million, the expansion included an additional twin-screw production line, improved blending and material handling capabilities. There were significant improvements made for QTR's employees, including additional lighting, ventilation, comfortable offices, locker rooms and break areas.

In 1993, QTR, Inc., began business as an ISO90000-registered Tier II supplier to the automotive industry specializing in custom compounding of recycled plastics. QTR's recycled product closely resembles prime materials, but provides significant cost savings to the end user.

QTR's sales growth has averaged more than 30 percent per year since the operation began in 1993. The company has 50 employees and sales of $\$ 12.5$ million a year. 
http://vnweb.hwwilsonweb.com/hww/jumpstart.jhtml?recid=0bc05f7a67b1790e43f188a0944caaa91001 18e9ed0e25b51bf9895f1915faeddaf283d3e90878d4\&fmt=H

Pennington, J. N. Press blanking line serves midwest automakers. Modern Metals v. 55 no. 10

(November 1999) p. 14-21

One customer's needs prompted building the first press blanking line at Mi-Tech Steel's Greensburg, Indiana, coil processing plant. The client is a major tier-one automotive supplier in the Midwest, and Greensburg's largest account, according to Stuart N. Ray, Mi-Tech president.

"They wanted to get out of their in-house blanking business, and bring in ready-to-stamp blanks instead of slit coils," he said. "If we were to continue as their source of steel, simply making sheared squares and rectangles would not be enough. We would need the capability of shaping first-operation configured blanks--asymmetric curves and circles--as well as trapezoids, parallelograms and chevrons."

The 72-in. wide line, with a 400-ton mechanical press, is unique in Greensburg's market, according to Ray. "I don't know of any other line with this width capacity and shape capability in central Indiana," he declared. "This region has needed a quality press blanker."

\section{JOINT VENTURE}

Mi-Tech is a joint venture of Steel Technologies, Inc., headquartered in Louisville, Kentucky, and Mitsui \& Co., Ltd., Tokyo, Japan. Formed in 1987, Mi-Tech was initially an entrée for the two companies into the lucrative supply network for Japanese transplant automobile plants. Twelve years later, Mi-Tech also numbers the U.S. automakers and their suppliers among its customers.

Steel Technologies is a processor/converter that cold rolls hot band into coils, and also pickles, anneals, slits and blanks. Mitsui is Japan's largest steel trading company, and is said to be the fifthlargest commercial organization in the world. Their Mi-Tech venture concentrates on slitting and blanking at plants in Greensburg, Murfreesboro, Tennessee, and Decatur, Alabama. It also operates a pickling line in Decatur.

Stuart Ray calls Mi-Tech a mature company, given the sometime transitory nature of joint ventures. And it represents over $\$ 40$ million in capital investment just in the past five years. The Murfreesboro operation began with 60,000 sq. $\mathrm{ft}$. and one slitting line; it now has a quarter-million square foot plant housing two slitters, a cut-to-length line, and an edge-trimming and inspection line. Greensburg has expanded from 80,000 sq. ft. to just over 200,000 sq. ft., with two slitting lines, a cut-to-length line and the press blanking line. The newest plant, at Decatur, includes two slitting lines as well as the pickling line.

The Greensburg press blanking line is a first for both Mi-Tech and Braner USA, which supplied all the equipment ahead of the stamping press. "We have built many cut-to-length lines," said Douglas Matsunaga, Braner president. "But they have all been equipped with shears. We had never built a blanking line that feeds into a stamping press."

Matsunaga foresees building more press blanking lines. "An increasing number of our customers want to provide the first operation on making a finished part," he pointed out. "They don't want to simply sell blanks by the pound."

\section{HOT ROLLED, COLD ROLLED AND COATED STEEL}

The line runs steel exclusively, hot-rolled, pickled and oiled, and cold rolled in thicknesses from 0.028 to 0.150 in. and a maximum yield strength of 50,000 psi. Coated steel accounts for up to 50 percent of Mi-Tech's press blanking, primarily electrogalvanized and hot-dipped galvanized.

A four-arm entry turnstile and coil car accept coils up to 50,000 lbs., with IDs of both 20 and 24 in. A peeler automatically threads the strip into the leveling section.

The 17-roll, four-high corrective leveler has 2-3/16-in. diameter work rolls and a 200-hp drive. Roll bending to remove camber, edge wave and center buckle is computer controlled.

"The computer calculates the required roll penetration and positions the rolls accordingly," Matsunaga explained. "The operator adjusts the roll positions as needed, reading a vertical bar graph 
on the computer display that illustrates the profile of the work rolls.

"Once a coil is running correctly, the operator assigns a job number to the leveler setting, so that the setting can be used for subsequent coils from the same mill. Mi-Tech can build a data base in the leveler control to recall previous settings." The line controller has memory capacity for 105 job numbers.

An 8-ft. deep looping pit separates the leveler and the press feed. Roller quadrants guide the strip into and out of the pit, and they have generous radii to avoid rebending the strip past its yield point. Maximum line speed upstream of the press feed is $200 \mathrm{ft} . /$ minute.

The AC servo press feed holds a length tolerance of $+/-0.003$ in., regardless of feed length. The chrome-plated feed rolls have a pneumatic pressure release linked to the press controller to allow the strip to float when running piloted dies.

The single-action, four-point press, built by Blow, has a 108- $x$ 84-in. bolster and a 36-in. shut height. The slide stroke is 12 in., at a maximum rate of $60 \mathrm{spm}$. To date it has produced blanks ranging in length from 13 to 96 in., and from 15- to 48-in. wide.

\section{FIFTEEN-MINUTE DIE CHANGES}

A 20,000-lb. capacity rolling bolster with automatic die clamping makes 15-minute die changes the norm, according to Brian Redding, general manager at Greensburg. "We need the quick die change capability because our press runs average 3500 parts. Some are as short as 1000 pieces, and rarely do they exceed 10,000 .

"When we were planning this installation, we visited several customers that operate their own press lines and have rolling bolsters. We saw right away the advantages of quick die changes, and decided that we would need the same capability."

Finished blanks are currently removed from the press by a conveyor and stacked manually on pin pallets. This may soon change, Redding indicated. "We are considering mechanical stackers, either a pneumatic pick-and-place manipulator or an articulated programmable robot."

Although the line is capable of processing automotive exposed metal, all of the configured blanks made in Greensburg are for interior parts. "We planned to specialize in unexposed components," Stuart Ray noted. "We did not equip the line with a washer."

\section{CONFIGURED BLANKS EXCLUSIVELY}

The press blanking line is reserved for configured blanks, he emphasized. "There's an axiom that if you use a press for cutting to length, you are going to go out of business. Squares and rectangles require the higher productivity of a cut-to-length line with a shear."

A recently installed 72 -in. cut-to-length line with a leveler produces 90 -degree sheared blanks, and complements the capacity of the press blanking line. "We also needed to provide high volumes of cutto-length blanks to our customers," Ray continued. "We didn't want to tie up the press blanking line with less value-added rectangles and squares."

Press blanking line products are currently about 20 percent of the Greensburg plant's total output, and Ray expects growth to 50 percent. Seventy-five to 80 percent of its metal is sold to the automotive industry, with the balance in household appliances--its second-largest market--and commercial furniture.

Mi-Tech's commitment to automotive should hold firm, Ray stated. "We're proud to be a supplier of the auto industry, both directly and indirectly. We don't foresee a time that the Greensburg facility will be less dependent on automotive sales."

ADDED MATERIAL

\section{J. NEILAND PENNINGTON}

Executive Editor

Seventy-two inch press blanking line at $\mathbf{M i}$-Tech Steel operates at $200 \mathrm{ft} . / \mathrm{min}$. upstream of the press feed. Length tolerance of AC servo feed is $+/-0.003$ in. Braner USA photo.

Mechanical press on blanking line is rated at 400 tons and cycles at up to $60 \mathrm{spm}$. Rolling bolsters and automatic die clamping effect 15-min. tooling changes. Mi-Tech Photo.

Want more information?

Blow Press, Ltd., Guelph, Ontario.

Braner USA, Inc., Schiller Park, Illinois.

Mi-Tech Steel, Inc., Louisville, Kentucky. 


\section{http:/ / www.expansionmanagement.com/ statespotlights/ I ndiana/ 18737}

\section{Spanish Company Missa Automotive to Locate Facility in Muncie, Indiana}

MUNCIE, Ind. (June 5, 2007) - The Indiana Economic Development Corp. offered Miasa up to $\$ 55,000$ in performance-based tax credits and $\$ 8,500$ in training grants based on the company's announced plans.

\section{[ 6/5/2007 ] By: NEWS BRIEFS}

Miasa Automotive LLC, a subsidiary of Spanish Miasa, a leader manufacturer of transmission components, recently announced that the company will establish its first U.S. presence in Muncie, Ind., creating 12 new jobs. The company will invest more than $\$ 1.4$ million to locate its new production facility northeast of the city of Muncie..

Miasa Automotive LLC will manufacture gearbox components for New York-based Magna Powertrain, an international supplier of engine and driveline components to General Motors, Ford, Honda, Toyota and BMW. 
Miasa's choice to locate its new operations in Indiana comes after Magna Powertrain requested that the company establish a U.S.-based operation to improve cost efficiency and product development. Miasa, a former supplier of a Muncie-based New Venture Gear, opted to locate in Indiana rather than colocating with Magna in New York due to East Central Indiana's established industrial network, according to Sergio Palacios, Miasa's project manager.

"Locating in Delaware County is the best option for our business," Palacios said. "We expect to see continued growth in the coming years through new contracts from Magna and the development of a new customer base."

The Indiana Economic Development Corp. offered Miasa up to $\$ 55,000$ in performance-based tax credits and $\$ 8,500$ in training grants based on the company's announced plans. Through the MuncieDelaware County Economic Development Alliance, Delaware County officials offered property tax abatement worth more than $\$ 25,000$.

Founded in Spain in 1968, Miasa designs, develops and produces gearbox components for vehicles through the casting and machining of light copper and aluminum alloy. The company currently exports its gearbox components, selector forks and transfer case actuators to Portugal, United Kingdom, France, Rumania, Germany and Brazil. 


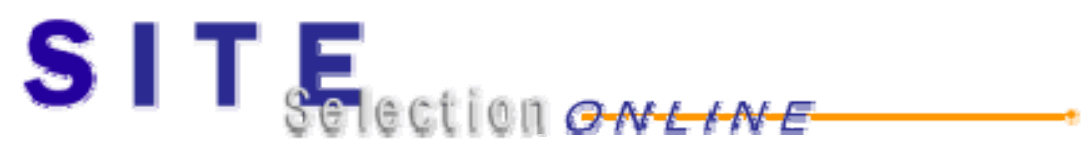

From Site Selection magazine, September 2006

NORTH AMERICAN REPORTS

\author{
Honda's Sure Thing \\ A new assembly plant in southeast Indiana is just \\ part of the solution for both a region and a company. \\ by ADAM BRUNS \\ adam.bruns@conway.com
}

D

uring his first weeks as director of the U.S. Office of Management and Budget under President George W. Bush, Indiana Gov. Mitch Daniels had to turn around budget numbers with preternatural speed: The 2000 general election dispute had delayed staff appointments, but it had not delayed budget deadlines.

So when he first heard about Honda's "Project Zoom" - the assembly plant component of a multi- state facilities buildout announced

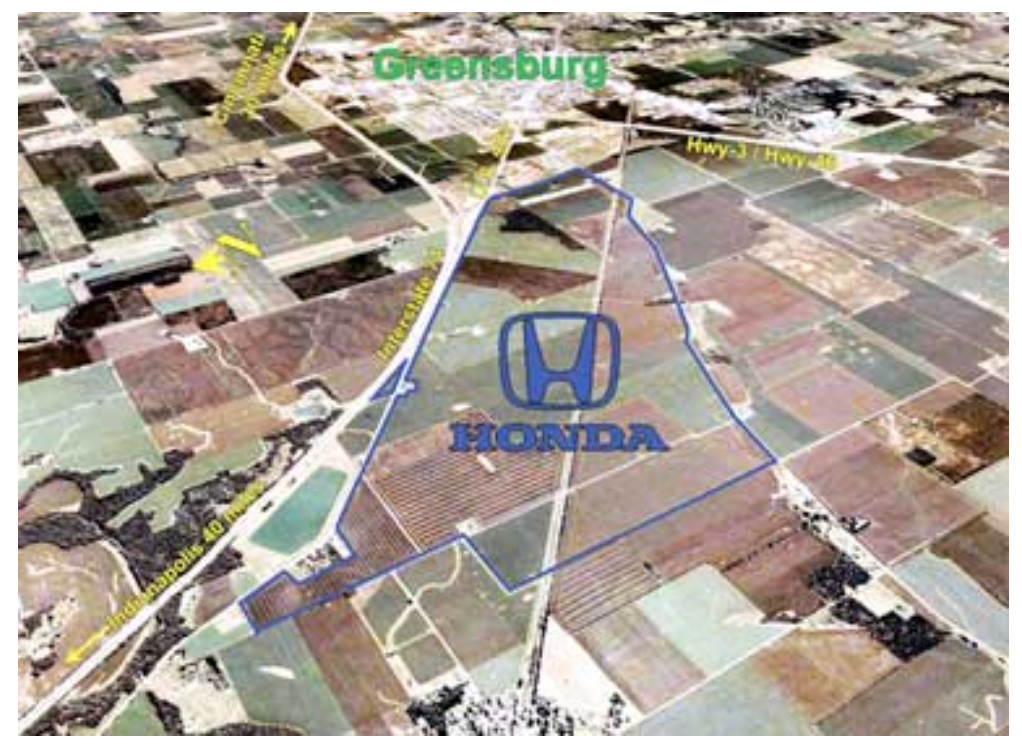

Honda will locate on 1,700 acres (688 hectares) in Greensburg, some 50 minutes southeast of Indianapolis. Murray Clark - a 
in May by Honda of America - its speed and the pressure that accompanied it were not exactly alarming.

"I received the first phone call [asking] whether I could be available within a week or two," Daniels tells Site Selection. "I said, 'No, I'll be at a place of your choosing tomorrow morning. I took a plane to a private location, and while there I called our Secretary of Commerce [Michael Maurer] cell to cell and asked him to fly the following day to meet with Honda, and that occurred too."

In the parlance of Daniels' old poker buddies at Princeton, that's called raising the stakes. But given the pace of projects just since J anuary from companies like Pfizer, FedEx, Nestle and Toyota - in fact, 110 deals committed to 14,300 new jobs and US\$3.7 billion in private capital investments - it wasn't a case of all- in.

Daniels, a former president of Eli Lilly and Co.'s North American operations, knows exactly what the speed of business requires, and has put that knowledge to good use in his first 18 months in office.

"I have sat where they sit on making investment decisions," he says. "Sometimes I hear from businesses we talk to that the questions we ask seem to come from a business perspective, as opposed to lifelong politicians they have dealt with elsewhere."

But by anyone's standards this one was fast - "the quickest of the many major deals we've done," says Daniels. Upping the ante may have accomplished just what it's supposed to at the card table: Getting attention. Four months after that first phone call, the dignitaries had assembled for the 2,000- job announcement in downtown Greensburg, which reportedly beat out finalist sites in Van Wert, Ohio; Fithian, IIl.; and two other nearby locations in Decatur Co., Ind., where the land options were not as easy to assemble into a winning hand.

\section{Get Your Money Back}

The card playing doesn't stop there. Key to making the \$550- million Honda project happen is a \$10- million contribution from the City of Lawrenceburg, 50 minutes from Greensburg, to the incentive package. Nestled on the Ohio River at the state line with Ohio, Lawrenceburg boasts a ski slope, but its real claim to fame is riverboat gambling. Having now caught up with the infrastructure deficit that the first wave of gaming tourism wrought, the forwardthinking leaders of Lawrenceburg decided some time ago to devote a significant portion of gaming money to helping their region at large. Does Daniels think this arrangement provides a new model for collaboration between two frequently warring sides of economic development?

"Yes I do," he says from RV One, his customized 2001 Beaver Patriot Thunder RV from Monaco Coach of Oregon, one of many RV manufacturers with plants in Indiana. Daniels has just boarded from a \$16- million expansion announcement by automotive supplier in the southeast Indiana town of Madison, not far from Greensburg. "Coincidentally, I'm going to Lawrenceburg to talk about this very subject," he says of the incentives boost.

But Daniels is clear: Incentives were "the very last thing we talked about with Honda. Honda was very modest in its requests, and the only incentives they were interested in were funds for infrastructure. The accurate number for Indiana's investment is $\$ 80$ million, and while we're at it we're going to build additional infrastructure that Honda doesn't 
need at all."

Combined state and local direct investment to support the Honda project includes EDGE tax credits, training assistance, and real and personal property tax abatements totaling up to $\$ 41.5$ million. In addition, there will be infrastructure support for water, wastewater and road improvements of approximately $\$ 44$ million. To accommodate future growth in the region, the state is expediting the long- sought interchange upgrade on Interstate 74 , along with water, wastewater, and other road upgrades totaling approximately $\$ 56$ million.

Daniels calls Lawrenceburg's substantial commitment "very material" to the process. "It's important in two dimensions," he says. "We would have found another way, but it made the transaction easier, and more balanced among state, local and regional entities. And it's a great model for regional cooperation, with the recognition two counties away that the whole area would benefit if Honda chose us.

"Before they knew anything about Honda, they were looking to invest something like \$10 million in the region each year," he explains. "Then this opportunity came, and this will be their Year One investment." Daniels hopes Lawrenceburg officials might see the Honda- related development as a good target for Years Two and Three as well. But for now, the pace has been set.

"I think it's a good model to be able to leverage those gaming receipts over a region," says Don Schilling, CEO of Decatur County Rural Electric Member Cooperative and also board president of the Greensburg- Decatur County Economic Development Corp. "Obviously a lot of those receipts are generated by people across the region, so it makes sense to return it to the region."

Decatur Co. REMC may serve some 7,300 meters in the six counties in its territory, but it's likely none carries a potential economic surge equal to new customer Honda. In the utility's case, the last stage of this site selection may have been lightning fast, but the early stages began more than two years ago.

"We started working to develop an industrial park on 260 acres [105 hectares] about two and a half years ago, which is now part of the Honda site," says Don Schilling. "About a year ago, we were able to get options on that acreage and the adjacent 180 acres [ 73 hectares] of land. From that point, the EDC, with the help of Executive Director Vicki Kellerman, was able to put a package together and apply for the new state program Shovel- Ready Sites. A little before we put in the application, we learned of a company looking at a site east of Greensburg. They were not successful in getting all the options they needed there. They went to a second site west of Greensburg and had similar results. We decided to offer our acres, they took it, and were able to assemble their 1,700- acre [688- hectare] site from that point."

One reason for the third option's success: a handful of landowners, versus several dozen at the other sites.

As part of the utility arrangement, power supplier Hoosier Energy is constructing two 138- kilowatt transmission lines to the site initially, with one more to come over the next year to serve the area. The total investment by Hoosier Energy and Decatur Co. REMC will be around $\$ 25$ million. But it's a good bet that investment, like Lawrenceburg's, will pay dividends.

"There has been a lot of debate in Indiana about taking money away from Lawrenceburg and other communities - this will end that debate," says Daniels. "This is a great model for using those proceeds to benefit an entire region in a very direct way."

The newly announced 117- acre (47- hectare) Markland Business Park in Switzerland County - across the Ohio River from a growing industrial area of Kentucky - also serves as testament to that model. With only 10,000 residents, but 
within a commuting circle that can capture as many as 250,000, the county's swift economic ascent has also been helped by riverboat gambling, with the Belterra Casino and Resort on the way to being home to the biggest hotel in the state. Jon Bond, president of the Switzerland County Economic Development Corp. says the region is poised to capitalize on both automotive and logistics growth. After all, the county is practically in the geometric center of recent huge facility expansions by DHL (southwest Ohio), FedEx (Indianapolis) and UPS (Louisville).

Further helping matters in the county is the extension of Kentucky Highway 1039 to the Markland Dam Bridge, which when completed this fall will enable a direct cross- river connection to growing Kentucky industries like North American Stainless in Ghent as well as to I- 71.

"The county hasn't nailed down the exact funding, but we're pretty sure gaming revenue will be involved" in funding the industrial park, says Bond, who expects to call the park shovel- ready when the property closing occurs in September.

The county's take from gaming and admissions receipts is not quite as large as some of its casino- hosting brethren, but it's enough to matter. "We're probably going to incur debt to fund this project, but we're looking at obligating gaming revenue to do that," says Bond, a native of the area who once served as director of operations for the state's economic development council and work force development efforts. And there is more land nearby, even though, as is usually the case in a river town, the availability of flat land out of the flood area is always a challenge.

"We have about four times as much [land] that's adjacent, and if we fill that up, we'll build a road to the top of the hill," Bond says. After all, he says, this is an unprecedented opportunity, and "this community is sophisticated enough that they're not going to pass that up."

\section{Pleasant Surprises}

Daniels likes direct. That's why he leaves the phone to climb down from the RV at the general store in rural Cross Plains, Ind., not far from Canaan and China. Once back on the line, he reports that several men in general construction just told him they're excited by the Honda project because they think more homes will be built.

Industrial prospects are anything but waning. Even after already announcing three major J apanese supplier expansions in the state in June and July (totaling \$116 million in investment and more than 266 jobs), Daniels

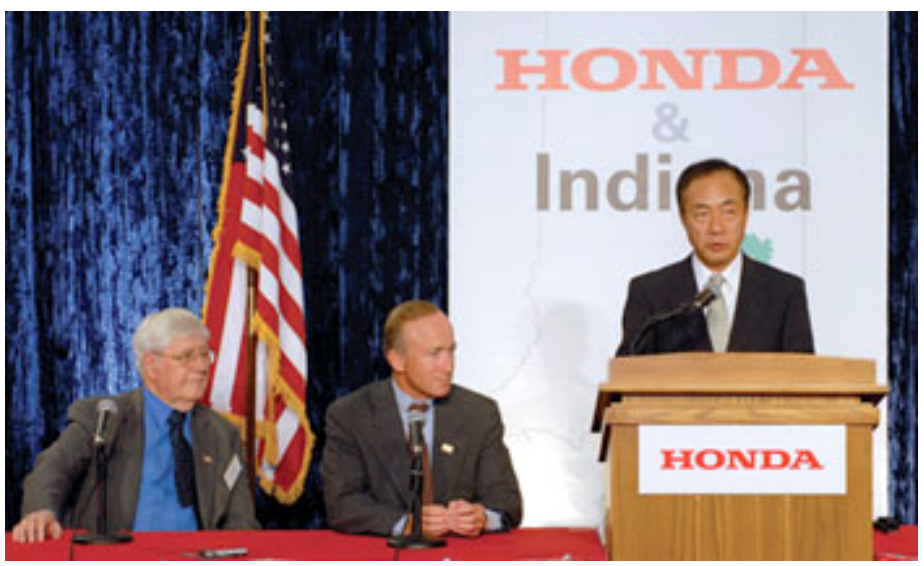


Greensburg, Ind., Mayor Frank Manus and Indiana Gov. Mitch Daniels mark the words of Koichi Kondo, $\mathrm{COO}$ of Honda's North American region and president \& CEO of American Honda, in announcing the location of Honda's new $\$ 400$ - million assembly plant. The company had announced its intent to build the plant on May 16, along with several other expansion projects in neighboring Ohio. says his lead development contact for the southeast region just told him that within the past five days, four different Tier 1 or Tier- 2 suppliers were scouting the area.

"More rapidly than I would have thought, the possibility of knock- on effects may be showing up," he says. "We've seen the same with Toyota, adding 1,000 jobs in Lafayette."

It's no surprise that the companies are Japanese, either, following on the governor's two visits to Asia in his first 18 months in office. Like neighboring Kentucky and Ohio, Indiana boasts a large contingent of J apanese companies, now numbering over 200. Daniels likes taking an active role in business recruitment and retention, and says hardly a day goes by when he doesn't call one or two companies to either thank them or encourage them. At the same time, his approach with the Indiana Economic Development Corp. is to look at recruitment deals as if the state were investing shareholder dollars. In other words, try to "win every deal, but at the lowest possible number."

The de- emphasis on incentive cash was right in line with Honda's outlook, but so were other factors that have laid the general economic development groundwork. Asked to assess the influence of certain initiatives on this deal and others, Daniels says yes, his $\$ 12$ - billion "Major Moves" transportation infrastructure plan was "unquestionably" a factor. For one, with its lease of the Indiana Toll Road, it means "we have cash in the bank earning interest we can use to pounce on opportunities like this." That includes new highway interchanges, bridge construction and relocation of rail lines.

Moving to single- factor corporate taxation is also a big deal, says Daniels. "Indiana has had a three- part basis, which meant the more investment and employees you had in the state, the higher your taxes were," he says. "There must have been logic to that, but I couldn't find it."

Neither can companies. Daniels recounts his conversations with Toyota officials prior to their Lafayette announcement, which like Honda carries a modest state incentives package, amounting to \$14 million.

"Toyota said an admirable thing to me," says Daniels. "They said, 'Listen, more important to us than any incentives is that eventually you move to the single factor taxation, so we no longer have a disincentive to invest here.' At the time, I said we're working on that, but to my surprise we did get it through this legislature. And Toyota will forego some of the small package we had agreed to."

Asked his thoughts on the efforts by U.S. Senator George Voinovich (R- Ohio) and others to pass national legislation freeing states to offer economic development incentives as they choose, Daniels says it's a tough issue, but erring toward more freedom for the states is preferable.

"I do favor letting freedom reign here, and letting states make their own mistakes if they're dumb enough to make them," he says. "There's no question it's a risky thing to let politicians loose with money that's not their money. They go to the ribbon cuttings and if the deal goes bad in a few years, they're probably somewhere else. Our approach at IEDC is to try to replicate the rigor and caution that a business takes with its own money. I think the better side of the argument is to allow states to compete aggressively, and the competition on a net basis will be good just like global competition is. It makes businesses better. And those who tax too much or move too slowly will sooner or later see the error of their ways." 
Having its own fiscal house in order has also helped Indiana, something which has surprised even a former OMB director. As its debt ratings rise, the state has its first balanced budget in eight years, and is also setting things straight fiscally with its school systems.

"I probably underestimated the attention some would pay to this," says Daniels. "If people believe a balanced budget and a stronger fiscal position reduces the possibility of tax increases, they'd be exactly right as far as we're concerned."

\section{Tri- State Triumph}

Honda officials declined to be interviewed for this story, saying all involved in the site selection were too busy moving the project forward. That's a sentiment to which many parties many North American communities can attest.

In April, a new \$123- million, 234,000- sq.- ft. (21,739- sq.- m.) paint shop went online at the company's plant in Marysville, bringing Honda's total capital investment in the state to $\$ 6.3$ billion over the past 26 years. There's also a $\$ 100$ - million expansion under way at a transmission plant in Russells Point, an \$89- million expansion of a parts warehouse in Troy and a \$75- million, 40- job expansion of the company's engine plant in Anna. That last project will mean more production of parts formerly supplied by J apanese plants, with some of them shipped to the company's engine plant in Alliston, Ont. - which is also expanding with a \$140- million, 340- job project.

The projects comprise Honda of America's "2010 Vision" for North America, which adds up to \$665 million and 1,900 new jobs, including a ramped- up transmission parts plant in Tallapoosa, Ga., that will now see $\$ 150$ million in capital investment and 440 associates at full capacity. Meanwhile, the parent company is even ramping up a business jet manufacturing venture with Piper Aircraft.

It may very well be the case that southeast Indiana is poised to mirror the fertile crescent of facilities that Honda already has worked to maximal productivity in central Ohio - another state that has reveled in recently upgraded bond ratings. The Ohio- Indiana- Kentucky momentum in the logistics and automotive sectors is undeniable. As J on Bond points out in Switzerland County, "in an area divided by a river, bridges dictate where activity can happen." And as metaphorical bridges between economic developers continue to be built as well, the hard infrastructure also rises to the occasion, also through collaboration. A case in point is the CIND line, a short line railroad operated by RailAmerica that is serving the new Honda project.

"The actual assembly plant will rest square in the middle of our mainline, so we will relocate our mainline to accommodate the plant and we will be the main carrier serving the plant out of Cincinnati and Indianapolis," says Tom Owen, senior vice president of business development and corporate strategy for RailAmerica, owner of 42 short lines in North America. Owen says there's quite a bit involved in serving a plant of this size, which will include a large amount of traffic interchange with Class 1 partners CSX and Norfolk Southern. Leading the punch list is an upgrade of parts of the main track that can't handle loads of $286,000 \mathrm{lbs}$., as well as bridge construction and some tie replacement. All totaled, Owen says the cost will be in the single- digit millions of dollars.

Charles McSwain, vice president, CSX, calls the project "a great example of how Short Lines and Class 1 railroads are working together to provide solutions to industry." Owen seconds that notion, and says he's seen dozens of industrial development decisions on the company's 42 lines in the past two years, and 80 percent of them involve access to multiple Class 1 railroads. Helping RailAmerica is its affiliation with industrial developer Agracel, which specializes in "agurban" facility development along short lines. As for land, he says, "There is a lot of soybean and corn growing out there on either side of our track, so there is abundant land."

Don Schilling concurs: "There is some other land that will be converted to industrial use over the next few years," he says of Greensburg's future. "It appears that there's some understanding that that corridor out I- 74 is a prime area for additional development."

Will the area be ready? Do Hoosiers know how to shoot free throws?

"It has every possibility," says Gov. Daniels of the region's potential. "As you look at the large Toyota plant in Princeton, clearly it had that sort of effect on other communities there, so we already see the first signs that could happen here. And we won't just sit back and hope for the best." 


\section{www.siteselection.com}

http://www.siteselection.com/issues/2006/sep/american/

http://www.supplierbusiness.com/database_endpoint.asp?id=6

www.in.gov/idoa/mwbe/docs/Honda\%20presentation.pdf

http://www.indianaeconomicdigest.net/main.asp?SectionID=31\&subsectionID=70\&articleID=32679

Honda material

http://www.indianaeconomicdigest.net/main.asp?SectionID=31\&subsectionID=70\&articleID=32678

Arvin Sango, others and JIT impact on supply chain

\section{$=\frac{1}{2}$ \\ Muncie Federal Credit Union

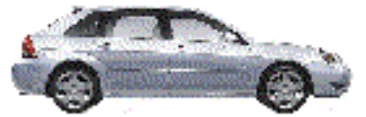

Newest wave of parts suppliers smaller, 'just in time' production

By KEITH ROYSDON

kroysdon@muncie.gannett.com

sтorrenat:Post Comment

MUNCIE -- Across Indiana, communities are scrambling to land the new wave of automotive assembly plants, and companies are beefing up their auto parts manufacturing operations. That activity is typical of the rapid changes in the supply chain.

"It's what localities are hoping for," said Susan Helper of Case Western Reserve University of Cleveland, Ohio, when asked about auto parts suppliers springing up in the wake of Honda's Greensburg assembly plant. 


\section{Appendix 6}

Complete data repository to be provided with the final report only via $C D$, due to amount of accumulated information related to this project. 